\title{
A Blessing in Disguise? \\ Effects of Oil Palm Adoption on Smallholder Farmers' Wellbeing and Agricultural Transformation in Indonesia
}

\author{
Dissertation \\ To obtain the degree of Dr. rer. pol. \\ in the International Ph.D. Program for Agricultural Sciences in Göttingen \\ (IPAG)
}

Presented by

Daniel Naek Chrisendo

Born in Jakarta

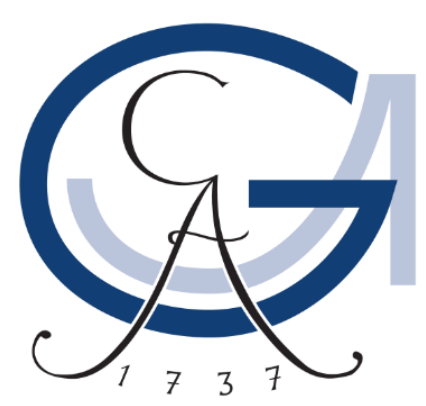

Chair of International Food Economics and Rural Development Department of Agricultural Economics and Rural Development Faculty of Agricultural Sciences Georg-August-University of Göttingen 


\section{Thesis committee}

Name of supervisor $\quad$ : Prof. Dr. Matin Qaim

Name of co-supervisor $\quad$ : Prof. Dr. Meike Wollni

Name of co-supervisor : Prof. Dr. Bernhard Brümmer

Date of disputation $\quad$ : 11 May 2021 


\section{Summary}

Dramatic land-use change in tropical regions due to oil palm expansion has recently raised controversies in the broader public. Indonesia is one of the countries where such rapid land-use change is happening. In many parts of Indonesia, oil palm is increasingly replacing forests and also more traditional agricultural crops such as rice and rubber. The drivers of this expansion are mainly higher profitability of the oil palm crop. Internationally, the demand for vegetable oil is increasing substantially, and oil palm is the most productive oil crop that can satisfy this rising demand.

As the biggest producer and exporter of palm oil globally, Indonesia's oil palm cultivation is associated with negative impacts such as greenhouse gas emissions, forest fires, biodiversity loss, and conflict over land. However, oil palm cultivation was also shown to improve the economic condition of smallholder farmers. These economic gains are undoubtedly important, considering that $40 \%$ of Indonesia's oil palm plantations belong to smallholder farmers. Therefore, both the positive and negative effects of oil palm expansion need to be considered by policymakers when designing relevant policies.

This dissertation aims to extend the current research about the effects of oil palm cultivation on smallholder farmers' socioeconomic status beyond a mere focus on income. Three essays compose this dissertation. The first essay explores the pathways on how oil palm cultivation may affect household nutrition and gender roles. The second essay examines to what extent oil palm cultivation may affect farm sizes and structural transformation more broadly in the medium and long run. The last essay investigates how oil palm contributes to the wellbeing of smallholder farm households in terms of human capital formation. All three essays are based on primary data collected from smallholder farm households in Jambi Province of Sumatra, one of the oil palm boom hotspots in Indonesia. Jambi is also one of the provinces with the highest share of smallholder farmers in oil palm cultivation. Therefore, conducting research in this area is highly relevant to see the consequences of oil palm cultivation on smallholder farmers' lives. Our research involves panel data with a time structure that enable us to observe impacts and impact heterogeneity over time.

Oil palm expansion has raised concern about food security as oil palm might compete with food crops in utilizing the land. In the first essay, we explore how oil palm affects household nutrition, mainly through rising income and gender roles. We hypothesize that oil palm improves farmers' income that is positively associated with their nutrition through food 
purchases. Another advantage of oil palm is its labor-saving characteristic that can free family labor, including women, from on-farm work to pursue off-farm work for the generation of additional income. The switch of women's role can increase female financial autonomy, thus improving the households' nutrition, as women often act as the primary caregiver for the family. Our findings show that oil palm cultivation is positively associated with household nutrition, measured by dietary diversity scores and the consumption of calories, vitamin A, zinc, and iron. Oil palm enables farmers to afford more nutritious foods from the market. Female off-farm employment is also positively associated with nutrition. But female off-farm employment seems to be unrelated to oil palm cultivation, possibly due to unequal opportunities and traditional culture that restrain women from pursuing off-farm work.

All countries with significant economic growth have seen a structural transformation of agriculture. This process involves productivity growth in farming, an increase in average farm sizes, and a shift of labor from agriculture to manufacturing and services. This phenomenon is also seen in Indonesia, where agriculture's contribution to gross domestic product (GDP) and the share of agricultural employment in total employment have been decreasing over time. As oil palm plantations expand and given that oil palm requires less labor than alternative crops, we investigate if oil palm cultivation contributes to paving the road to Indonesia's structural transformation. In the second essay, we show that oil palm adoption increases the average farm size. However, it does not increase the likelihood of households participating in the manufacturing or services sectors, probably due to the limited non-farm labor demand in the local settings. This finding needs to be carefully discerned as households with extra labor, but without enough off-farm job options, have strong incentives to expand their farm, which might lead to further deforestation.

Although we know that oil palm increases farmers' income, little is known about how farm families actually spend the extra income. In the third essay, we are particularly interested to understand if the rising income from oil palm is invested in human capital formation, social needs, and material resources. These indicators capture different dimensions of human wellbeing and living standard. We employ relevant variables, including health, education, housing, electricity, and communication. Some of these variables have never been analyzed before. In general, our results show that oil palm has positive effects on most of the variables that we use. The results suggest that oil palm is positively contributing to various dimensions of smallholder farmers' wellbeing and living standards. 
Despite the fact that we found several positive effects in our study, further oil palm expansion at the environment's cost is not desirable. Socioeconomic and environmental factors are important in every sustainability discussion and should both receive high priority. Even though the expansion of oil palm that already happened can hardly be reversed, existing plantations can be regulated sustainably by considering various aspects. This dissertation reveals a perspective on oil palm cultivation that is often neglected in the public debate: oil palm can be a blessing if managed in a sustainable way. These findings are essential when designing policies related to oil palm cultivation, sustainable livelihoods, and broader rural development. 


\section{Acknowledgment}

My doctoral study and this dissertation would not be completed without the supports of many people, professionally and personally. It is a pleasure for me to acknowledge them.

I have been fortunate to have Prof. Matin Qaim as my supervisor and mentor. I thank you for giving me the opportunity to work together with you. I have learned a lot during my years in Göttingen. Despite some limitations that I had, you were able to see my potential. I thank Prof. Meike Wollni and Prof. Bernhard Brümmer for being on my thesis committee and giving me helpful advice in developing my papers.

Indonesia Endowment Fund for Education (LPDP) supported my doctoral study. LPDP commenced in 2013 but already sent almost 30,000 young Indonesians to pursue master's and doctoral degrees worldwide as part of the Indonesia Golden Generation 2045 plan. I am proud to be part of the initiative.

Thanks, Ilona, who always found a way to solve my administration problems. For the immense work of C07: Nadjia, Kibrom, and to my research assistants, especially Amrina, Dilla, Fitryah, Irham, Juwita, Lia, May, Saut, Shara, and Winda. For Vijesh, who helped me develop my research proposal before I arrived in Göttingen and co-authored my first paper. I would like to extend my gratitude to our Indonesian counterparts, Prof. Hermanto Siregar and Prof. Zulkifli Alamsyah, for supporting our research in Indonesia.

To my colleagues that turned into friends: Anette, Anjali, Carina, Dienda, Hamid, Isabel, and Zewdu, you made my life easier at work. For Bernhard and Christoph, who kept me sane when the road was getting really tough, who checked me out when you were already back in Germany but I was still struggling in Sumatra, and who maintain friendships beyond work. For wonderful friends who are my family in Göttingen: Arieska, Rahmi, Hadis, and Tobias.

Special thanks to my extraordinary family. For Mama, I know that you are unease that I chose to live far away from you. But thank you for believing and letting me go to pursue what I think is important for me. Sorry that I could not be there during your difficult times. Also, to Melissa, Davin, Raynhard, Melody, Hillary, and Jeremy, thank you for being there for each other and motivating me to become a better person every day. Especially to Monica, I am glad to have you as a very supportive sister and friend. Also, thank you for helping me in the field. I knew that I can always rely on you.

Last but not least, Lieber Pascal, schön, dass es dich gibt. 


\section{Table of contents}

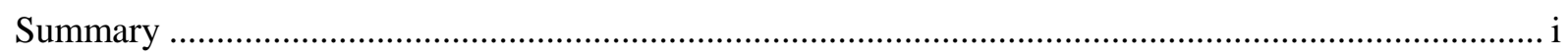

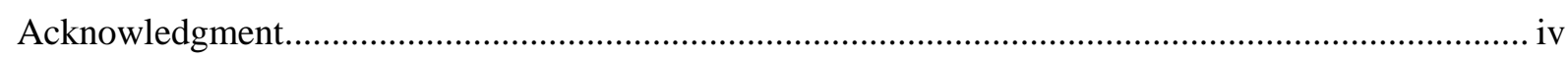

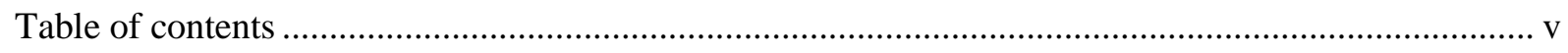

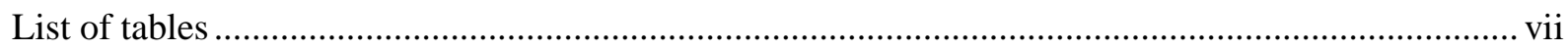

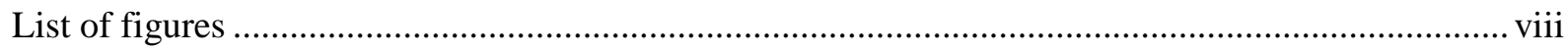

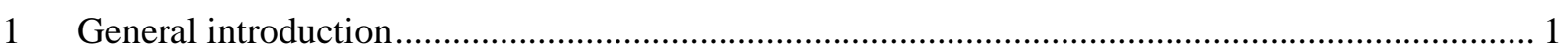

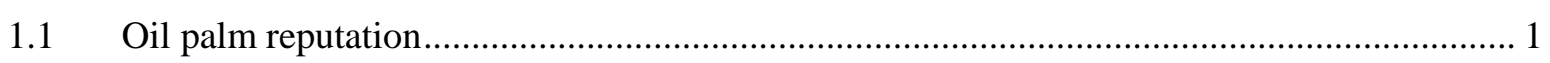

1.2 Oil palm expansion in Indonesia as a rural development strategy ....................................... 2

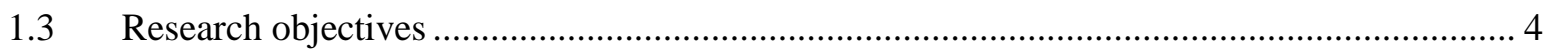

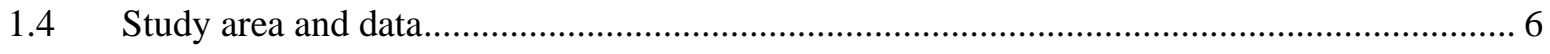

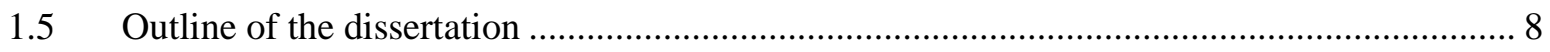

2 Land-use change, nutrition, and gender roles in Indonesian farm households .............................. 9

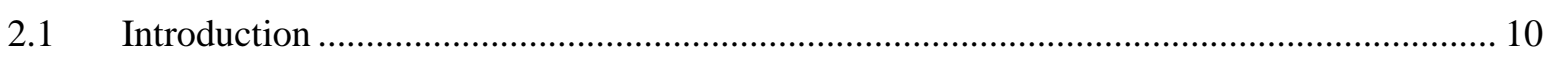

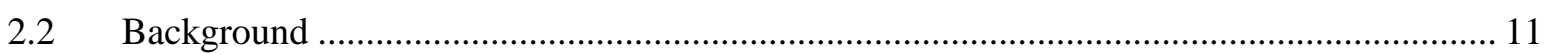

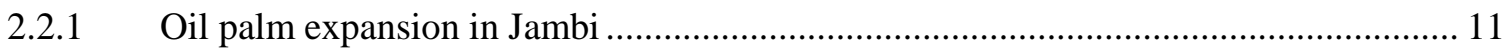

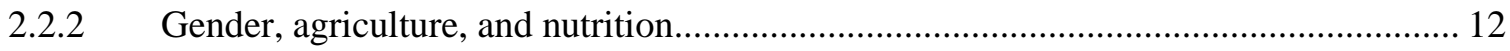

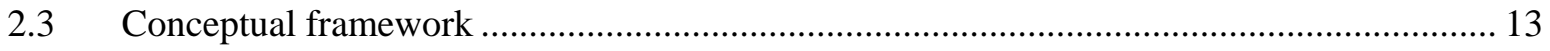

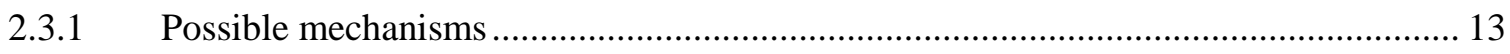

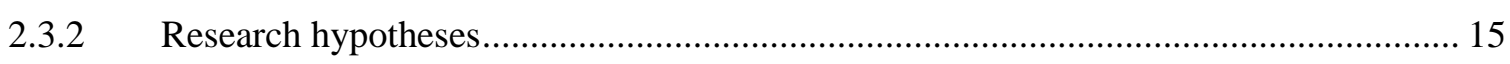

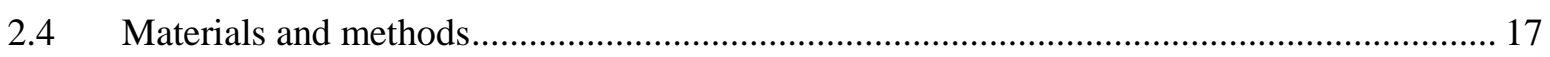

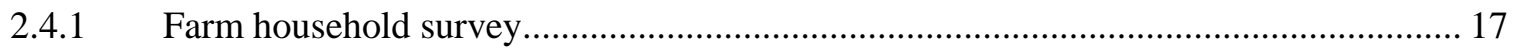

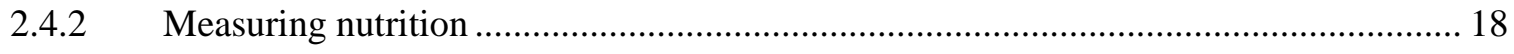

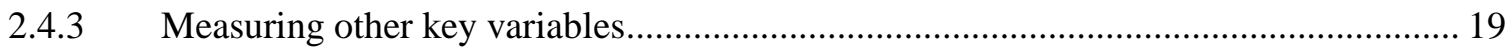

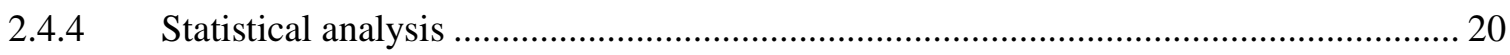

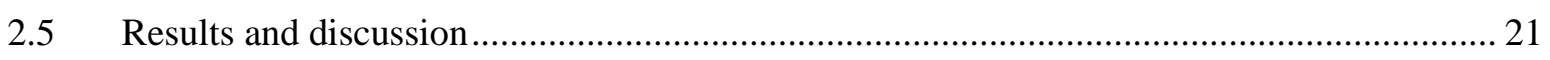

2.5.1 Household expenditures and dietary quality with and without oil palm ...................... 21

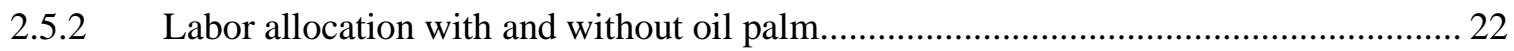

2.5.3 Associations between oil palm cultivation and nutrition............................................. 24

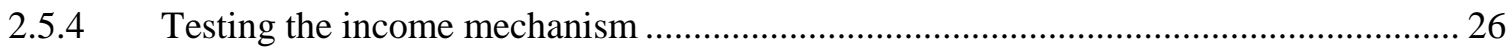

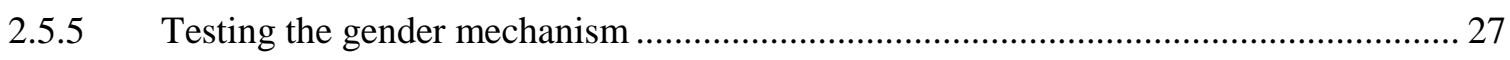

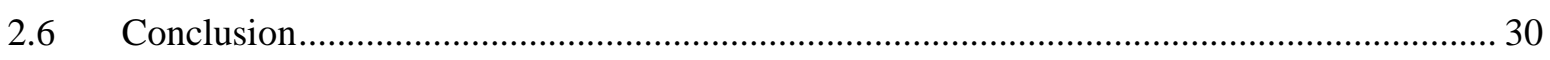

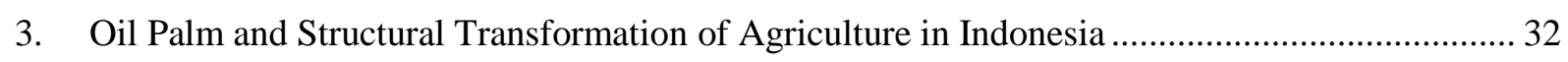

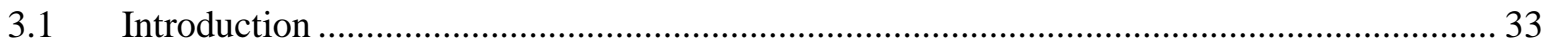

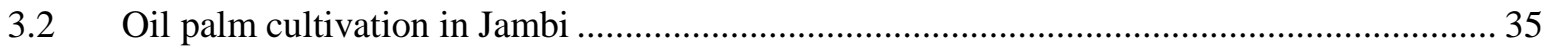

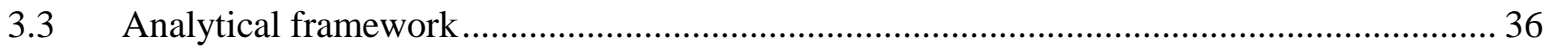

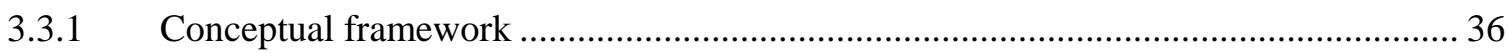




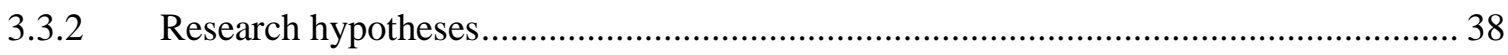

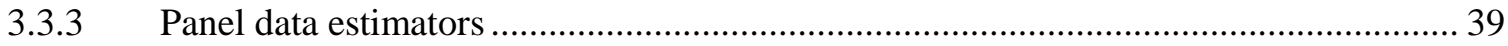

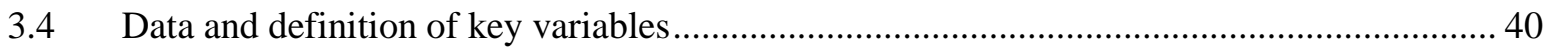

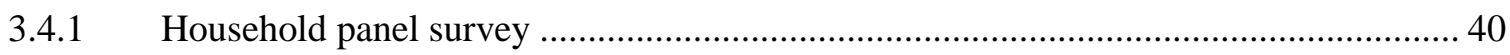

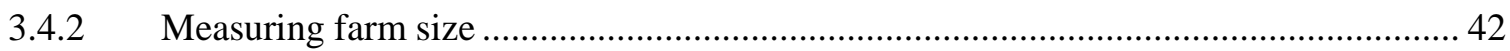

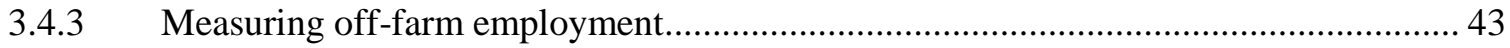

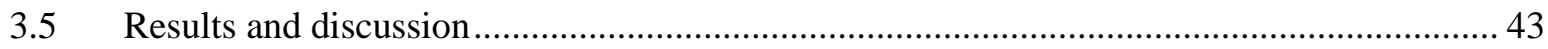

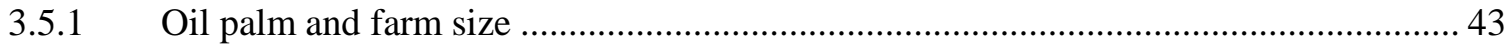

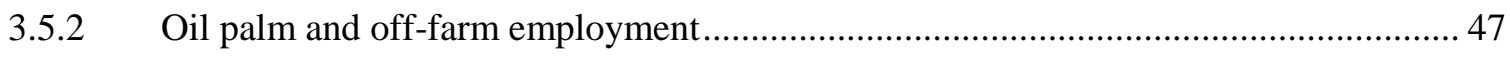

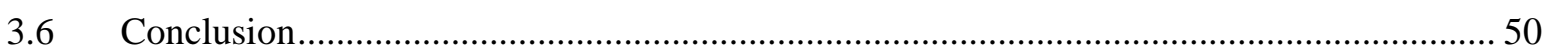

4. Does oil palm cultivation improve the long-term wellbeing of smallholder farm households?.... 53

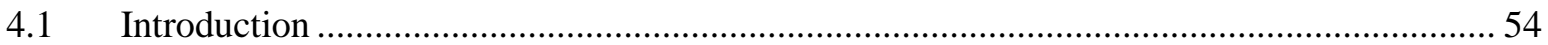

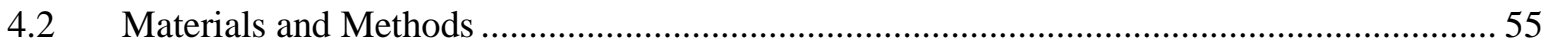

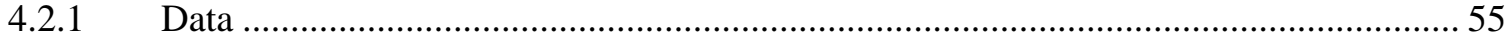

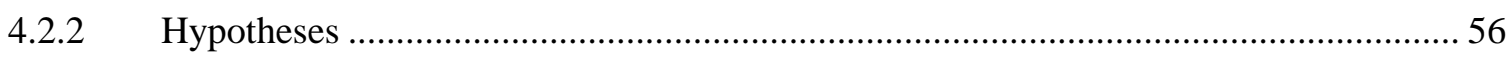

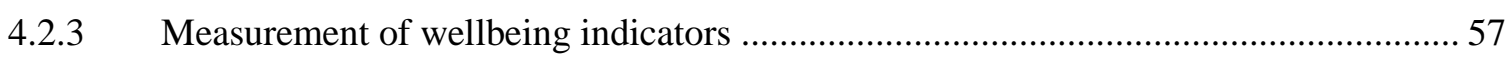

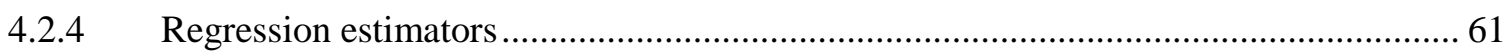

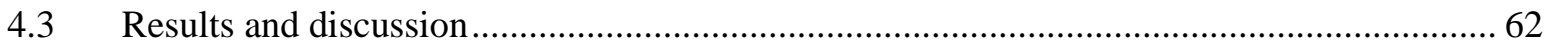

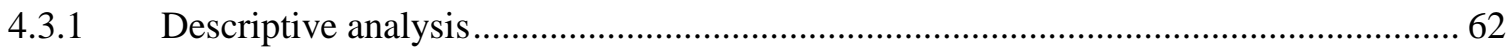

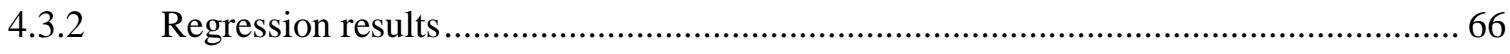

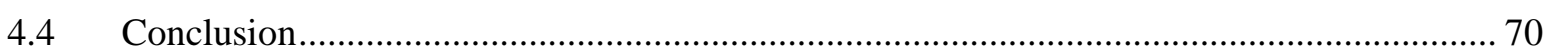

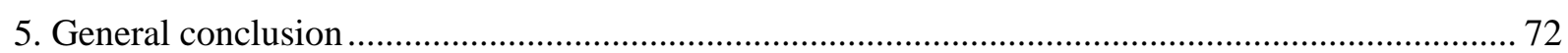

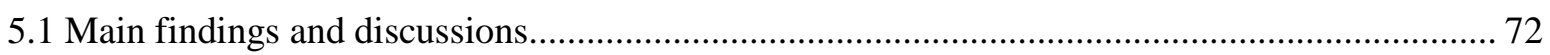

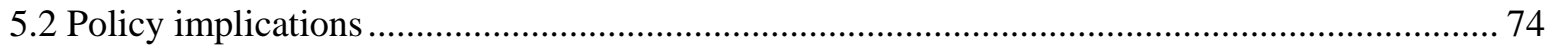

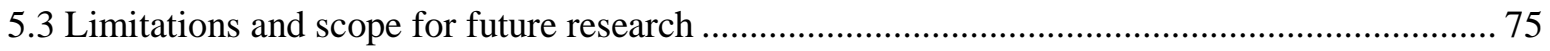

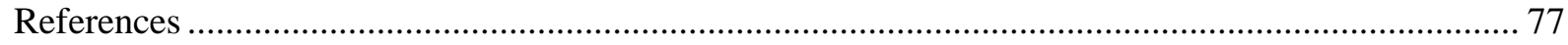

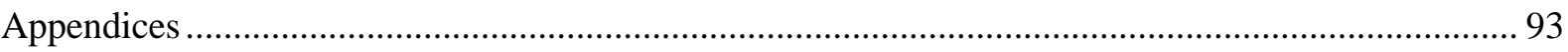

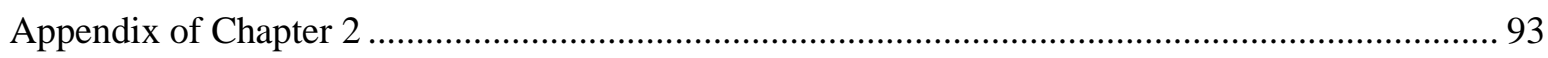

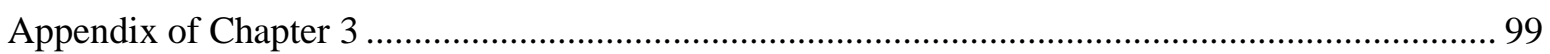

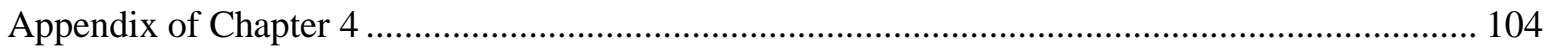

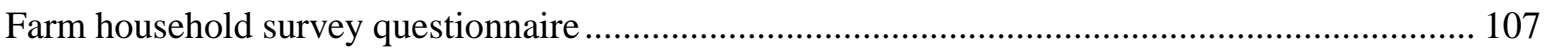

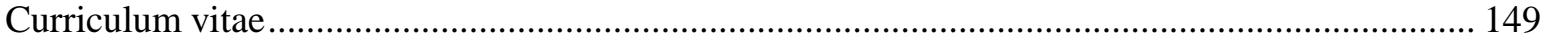




\section{List of tables}

Table 1 Expenditures and dietary quality by farm household type .................................................... 21

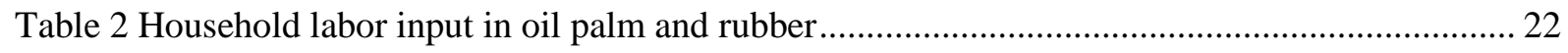

Table 3 Dietary quality in households with and without off-farm employment .................................. 24

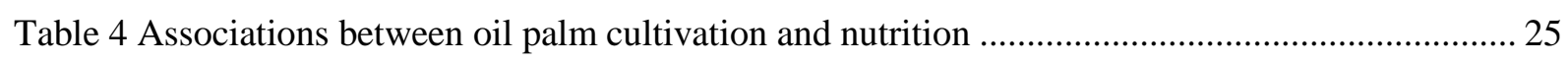

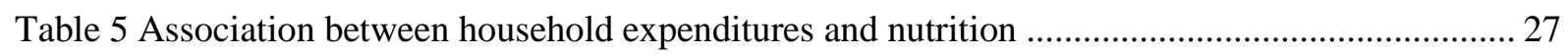

Table 6 Associations between oil palm cultivation and household labor allocation by gender ............ 29

Table 7 Number of farm households included in the panel survey ..................................................... 41

Table 8 Determinants of farm size (panel data regression models) ....................................................... 46

Table 9 Household characteristics of oil palm adopters and non-adopters ........................................... 48

Table 10 Determinants of participation in off-farm activities (FE panel data models) ......................... 50

Table 11 Number of oil palm adopters and non-adopters within sample across three survey years ..... 62

Table 12 Household nutrition and health expenditure by oil palm adoption status (pooled) ................ 63

Table 13 Household education by oil palm adoption status (pooled) …............................................... 64

Table 14 Household electricity and communication expenditure by oil palm adoption status ............. 65

Table 15 Effects of oil palm cultivation on dietary diversity and calories consumption ...................... 67

Table 16 Effects of oil palm cultivation on health expenditures (in logarithm IDR) .......................... 68

Table 17 Effects of oil palm cultivation on different kind of expenditures (in logarithm IDR) .......... 69

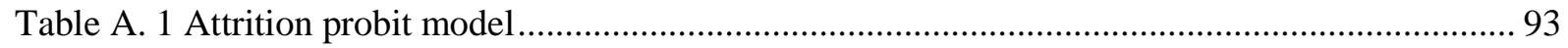

Table A. 2 Association between oil palm cultivation in 2012 and nutrition indicators in 2015 .......... 94

Table A. 3 Associations between oil palm cultivation and nutrition using transmigration variables ... 95

Table A. 4 Association between household expenditures in 2012 and nutrition indicators in 2015 ..... 96

Table A. 5 Association between oil palm cultivation in 2012 and labor allocation in 2015 ................ 97

Table A. 6 Association between female and male labor allocation and nutrition indicators ................ 98

Table A. 7 Determinants of participation in off-farm activities (RE panel data models).................... 101

Table A. 8 Determinants of participation in off-farm activities (RE logit panel data models) ........... 102

Table A. 9 Determinants of participation in off-farm activities (multivariate probit model).............. 103

Table A. 10 Household nutrition and health expenditure by oil palm adoption status and survey year

Table A. 11 Household education by oil palm adoption status and survey year. 105

Table A. 12 Household electricity and communication expenditure by oil palm adoption status and survey year 


\section{List of figures}

Figure 1 Location of villages in Jambi and location of Jambi in Indonesia ........................................ 7

Figure 2 Possible mechanisms of the association between smallholder oil palm cultivation and nutrition

Figure 3 Gendered off-farm employment in households with and without oil palm ........................... 23

Figure 4 Oil palm adoption and structural transformation (possible mechanisms) ............................... 37

Figure 5 Development of average farm size in Jambi (1998-2018) .................................................... 44

Figure 6 Development of mid-point farm sizes in Jambi for oil palm adopters and non-adopters (19982018)

Figure 7 Annual off-farm income of oil palm adopters and non-adopters (2012-2018) ....................... 48

Figure 8 Household asset ownership and housing condition by oil palm adoption status 65

Figure A. 1 Distribution of number of farms and of total farm land in Jambi (1998-2018) ....... 99

Figure A. 2 Development of total land cultivated by sample farms (1998-2018) 100 


\section{General introduction}

\subsection{Oil palm reputation}

It is a dilemma to conduct socioeconomic research about oil palm. Studies that find positive effects of oil palm cultivation, particularly when related to poverty alleviation and economic growth, are sometimes reckoned as attempts to justify the displacement of orangutan, forest fire, or eviction of indigenous people (Sayer et al., 2012; Choiruzzad, 2019). Oil palm has been long framed as a crime against humanity (Meijaard \& Sheil, 2019). This is not groundless. Studies have shown that oil palm expansion contributes to biodiversity loss, environmental degradation, and social conflict, especially in Indonesia (Obidzinski et al., 2012; Marlier et al., 2015; Drescher et al., 2016; Abram et al., 2017; Grass et al., 2020), which now ranks as the largest palm oil producer globally (FAO, 2020). Those negative effects are widely altercated. However, positive economic outcomes are communicated to a lesser degree, which creates skepticism towards oil palm benefits (Meijaard \& Sheil, 2019; Qaim et al., 2020).

Population growth, rising income, and changes in consumer preferences indirectly escalate the global demand for vegetable oil, which is a raw material of many products ranging from cosmetics, processed food, to fuel (Corley \& Tinker, 2016; Byerlee et al., 2017). As the most productive oil crop per unit of land globally, oil palm can respond to this demand more efficiently than any other oil crop (Sayer et al., 2012; Meijaard et al., 2020). This is, of course, an economic opportunity for countries with climatic conditions suitable for oil palm cultivation, especially tropical regions characterized by their warm temperature, high humidity, and high exposure to solar radiation (Carrere, 2013; Corley \& Tinker, 2016). Along with the country's abundance of land and labor force, oil palm can procure livelihoods for people who live in poor rural Indonesia with limited opportunities (Zen et al., 2006; McCarthy et al., 2012). Just as important, oil palm can be a reliable source of income as it is productive all year long, during the wet and dry seasons (Byerlee et al., 2017). Indeed, studies have reported positive economic effects in areas where oil palm is cultivated (Feintrenie et al., 2010; Euler et al., 2017; Bou Dib et al., 2018b; Kubitza et al., 2018a).

We should not neglect those positive implications of oil palm as they accord with the Sustainable Development Goals (SDGs), especially SDG 1 "poverty eradication" and SDG 8 "economic growth". Nonetheless, oil palm cultivation potentially clashes with other SDGs, especially SDG 13 "climate change combat" and SDG 15 "biodiversity loss halt". This is 
certainly a puzzling situation as all 17 SDGs are targeted to be achieved together and bear the same priority (UN General Assembly, 2015). Therefore, trade-offs among these goals are very likely to happen, meaning studies about the consequences of oil palm on various dimensions should be considered carefully.

This dissertation is part of Deutsche Forschungsgemeinschaft (DFG)-funded interdisciplinary research; the Collaborative Research Center (CRC) 990: Ecological and Socioeconomic Functions of Tropical Lowland Rainforest Transformation Systems (Sumatra, Indonesia). This CRC research focuses on smallholder systems in the Indonesian Province of Jambi, where land use has been transformed from forests or traditional crop plantations to oil palm plantations of substantial size (Grass et al., 2020). The CRC 990 aims to provide evidence that hopefully can help policymakers constitute the best land-use strategy, accounting for sustainability.

This dissertation enriches knowledge about the local-scale economy and wellbeing related to oil palm with comprehensive micro-level data that allow the analysis of effects beyond a simple income dimension. Three essays compose this dissertation. The first essay focuses on the effects of land-use change and oil palm cultivation on nutrition and gender roles in smallholder farm households. The second essay investigates to what extent and through what pathways oil palm cultivation influences structural transformation. The last essay analyses the effects of oil palm cultivation on long-term wellbeing in smallholder households. All three essays focus on smallholder farmers with variables of interest that are relevant to the SDGs. Besides SDG 1 and SDG 8, they are linked to SDG 2 "zero hunger", SDG 3 "good health and wellbeing", SDG 4 "quality education", and SDG 5 "gender equality". In general, we find positive effects of oil palm cultivation on smallholder farmers' lives, albeit with remaining challenges for some of the environmental and climate-related SDGs. After further understanding both positive and negative implications of oil palm cultivation, in the end, we leave it up to the readers to judge whether or not oil palm is a blessing in disguise.

\subsection{Oil palm expansion in Indonesia as a rural development strategy}

Oil palm was brought to the Dutch East Indies (now Indonesia) from Africa by the Dutch colonial government in the mid of 19th century (Cramb \& Curry, 2012). In the first half of the 20th century, oil palm still played a minor role and was mostly grown in Sumatra. The focus to make the oil palm sector more coordinated just began in 1968 when the Indonesian government merged former Dutch plantations into 28 state-run companies (Larson, 1996). From the early 
1980s, the Indonesian government started to use oil palm as a rural development strategy by combining it with the transmigration program that involved smallholder farmers (Gatto et al., 2017; Zen et al., 2016). The program was an initiative of the Dutch colonial government and later continued by the Indonesian government to reduce poverty, create employment, and relocate people from densely populated islands of Java, Bali, and Madura to scarcely populated islands, such as Sumatra (Fearnside, 1997; Bazzi et al., 2016). The transmigrants were given approximately two hectares of land for settlement, food production, and cash crop production, such as oil palm (McCarthy \& Zen, 2016).

In the mid-1980s, the Indonesian government welcomed new actors in the oil palm sector, namely private companies and foreign investors. Cooperation between these actors and smallholder farmers were enforced under the Nucleus Estate and Smallholder (NES) scheme (Larson, 1996). Under this scheme, land, agricultural inputs, training, credits, and village infrastructure were provided to smallholders (McCarthy \& Zen, 2016; Rist et al., 2010). In return, the smallholders had to sell their oil palm fruits to the private companies for processing (Feintrenie et al., 2010).

In Sumatra, the government's active involvement has been gradually reduced (Gatto et al., 2017). In this case, private companies negotiated directly with the farmers without government assistance, and most smallholder plantation expansions occurred independently of government programs, sometimes replacing more traditional crops such as rubber and rice (McCarthy et al., 2012). The number of independent oil palm adopters increased as knowledge about oil palm production disseminated, and farmers perceived financial returns as high. Moreover, credits, planting materials, and inputs were easily accessible as the input and credit market developed because of the liberalization. The adoption of oil palm became self-sustaining and shifted from the government-led phase to the market-oriented phase (Gatto et al., 2017). Meanwhile, in the region where oil palm was introduced more recently, such as Borneo and Papua, NES has been administered progressively by the government to engage smallholder farmers following the same strategy-path as in Sumatra (Obidzinski et al., 2012; Obidzinski et al., 2014).

The massive expansion of oil palm in Indonesia has brought the country to be the largest palm oil producer in the world (FAO, 2020), unfortunately with environmental and social costs. Rapid oil palm expansion was obtained through extensive deforestation and led to tenure conflicts, violation of community rights, illegal land clearing, biodiversity loss, and other issues that have been reported continuously in the oil palm frontiers of Indonesia (Obidzinski et al., 2012; Li, 2015; Levang et al., 2016; Abram et al., 2017). 
On the other side, studies have displayed positive effects of oil palm cultivation on rural development and poverty alleviation, especially on smallholder farmers who cultivate more than $40 \%$ of the country's total oil palm area (Ministry of Agriculture Indonesia, 2019a). At the household level, oil palm adoption was shown to increase household income and expenditure due to higher profits than from more traditional crops such as rubber and rice (Euler et al., 2017; Feintrenie \& Levang, 2009; Feintrenie et al., 2010; Kubitza et al., 2018a). Moreover, oil palm cultivation requires less labor than previously cultivated rubber, enabling households to participate in off-farm employment, thus generating additional income (Euler et al., 2017). Nonfarm households benefit through employment in oil palm plantations, which was found to improve their living conditions (Bou Dib et al., 2018b; Rist et al., 2010). Significant economic improvements were also reported for other parties involved in the supply chains, such as traders and intermediaries (Bou Dib et al., 2018b; Euler et al., 2017; Feintrenie et al., 2010). The Ministry of Agriculture (2019a) reported that over 2.5 million farmers and over 4.2 million laborers in Indonesia earn a living from oil palm plantations.

Economic benefits at the village and regional level include positive effects on village assets, including road and market infrastructure, electricity, schools, and healthcare facilities (Edwards, 2019a; Gatto et al., 2017; Rist et al., 2010; Zen et al., 2016). At the national level, oil palm production was acknowledged to contribute to poverty alleviation, indicated by lower poverty rates in areas surrounding oil palm plantations (Dradjat, 2012; Susila, 2004) and a faster decline in poverty rates (Edwards, 2019b). However, it should be noted that oil palm did not benefit all households and villages to the same extent (Gatto et al., 2017; McCarthy et al., 2012). Not all farm households, especially the poor, succeeded in adopting oil palm as the plantation establishment is capital-intensive (Euler et al., 2016; McCarthy \& Zen, 2016). Local settings and other social indicators also play essential roles (Santika et al., 2019a; Santika et al., 2019b).

\subsection{Research objectives}

This dissertation consists of three essays, which attempt to analyze the broader socioeconomic effects of oil palm on smallholder farmers and on structural transformation in agriculture. The cultivation of cash crops is often challenged because it might compete with using land for food crop production with possible negative effects on farm households' nutritional status (Anderman et al., 2014). Oil palm is presumed to create the same problem ( $\mathrm{Li}, 2015)$. But studies that link oil palm adoption and farmers' nutrition are limited. Through the first paper, 
we want to formally analyze how oil palm cultivation is associated with farm households' nutrition. We use several nutrition indicators, namely the dietary diversity score (DDS), and consumption levels of calories, zinc, iron, and vitamin A, which are often inadequate in developing countries (Development Initiatives, 2018). We develop a framework showing how oil palm might be associated with diets and nutrition, primarily through raising income and changing gender roles. We hypothesize that oil palm cultivation is positively associated with household nutrition due to rising income, increasing farmers' purchasing power of nutritious foods from the market. Oil palm is also less labor-intensive than rubber (Feintrenie \& Levang, 2009; Euler et al., 2016). Adopting oil palm can release family labor, including women who often act as the family's primary caregiver. The reduction of women's roles on-farm may increase their role in off-farm income-generating activities, thus improving women's financial autonomy and, eventually, the household's nutritional status.

The second essay evaluates the relationship between oil palm cultivation and structural transformation of agriculture. Countries with significant economic growth have engineered structural transformation that involves productivity growth in farming, and the agriculture sector losing in relative importance in the overall economy (Berger \& Frey, 2016; Bokusheva $\&$ Kimura, 2016). This process is indicated by an increase of average farm sizes and reallocation of labor from the agricultural sector to manufacturing and services (Duarte \& Restuccia, 2010; Herrendorf et al., 2014). Indonesia's agriculture has also gradually lost in relative importance. Its contribution to total GDP has been decreasing, as well as the share of agricultural employment in the total country's employment (World Bank, 2020). As mentioned, oil palm is a labor-saving crop that can contribute to structural transformation. However, we are not aware of any study investigating this relationship. First, we hypothesize that oil palm cultivation increases average farm sizes. Second, we hypothesize that oil palm cultivation increases the likelihood of household involvement in different kinds of off-farm income-generating activities. Both are feasible due to the surplus of labor because of oil palm cultivation.

Though many studies have confirmed that oil palm cultivation increases farmers' income, little is known about how farmers really spend the extra income. In the third essay, we explore the effects of oil palm cultivation on smallholder farm households' long-term wellbeing. It is essential for income to be invested in human capital, material resources, and social needs that can improve the households' wellbeing and living standard. Otherwise, the cultivation of oil palm can backfire as it already creates negative impacts on the environment, even worse when it does not improve farmers' wellbeing. We use several relevant variables as indicators to 
measure wellbeing, including nutrition, health expenditure, education, housing, and communication. We hypothesize that oil palm cultivation increases farmers' wellbeing measured by those variables.

To generate results for the three dissertation essays, we use a unique panel dataset that is explained in more detail in the following section. With panel data, we can also analyze the effects of oil palm cultivation over time. The models can be estimated using random effects (RE) and fixed effects (FE) panel estimators. In each essay, we will explain which particular panel estimators we prefer for what particular model.

\subsection{Study area and data}

Three essays in this dissertation were developed using primary datasets collected in Jambi Province, in Sumatra, Indonesia, where other sub-projects of CRC 990 parallelly conduct their research (Drescher et al., 2016; Grass et al., 2020). Out of 14.3 million hectares of Indonesia's total oil palm plantation, around one million hectares are situated in Jambi. From those one million hectares, about $63 \%$ are categorized as small- and medium-sized family farms. This number puts Jambi as one of the oil palm expansion hotspots and one of the provinces with the highest shares of smallholder oil palm farmers in Indonesia (Ministry of Agriculture Indonesia, 2019a).

The data were collected through surveys of farm households in three different waves with threeyear gaps in-between during the dry season in 2012, 2015, and 2018. The first essay was prepared before the 2018 survey was conducted; therefore, it builds on only the 2012 and 2015 datasets. Meanwhile, the second and third essays utilize the data from all three survey waves. The 2012 and 2015 surveys were conducted by other research teams (Euler et al., 2016; Kubitza et al., 2018a), while the author of this dissertation was involved in the 2018 data collection. Samples from the 2012 wave were chosen through a multi-stage sampling procedure. Five out of eleven regencies representing the largest lowland area in Jambi were selected purposively, namely Sarolangun, Batanghari, Muaro Jambi, Tebo, and Bungo. From each regency, four districts were chosen randomly. From each district, two villages were selected randomly, which makes 40 villages. Five additional villages were included purposively for interdisciplinary research jointly with other sub-projects, resulting in a total of 45 villages being selected. Depending on the population, 6 to 25 households who owned agricultural land for the past five 
years were randomly sampled in each village. In total, 701 farm households were interviewed in 2012. Figure 1 shows where the villages are located in Jambi Province.

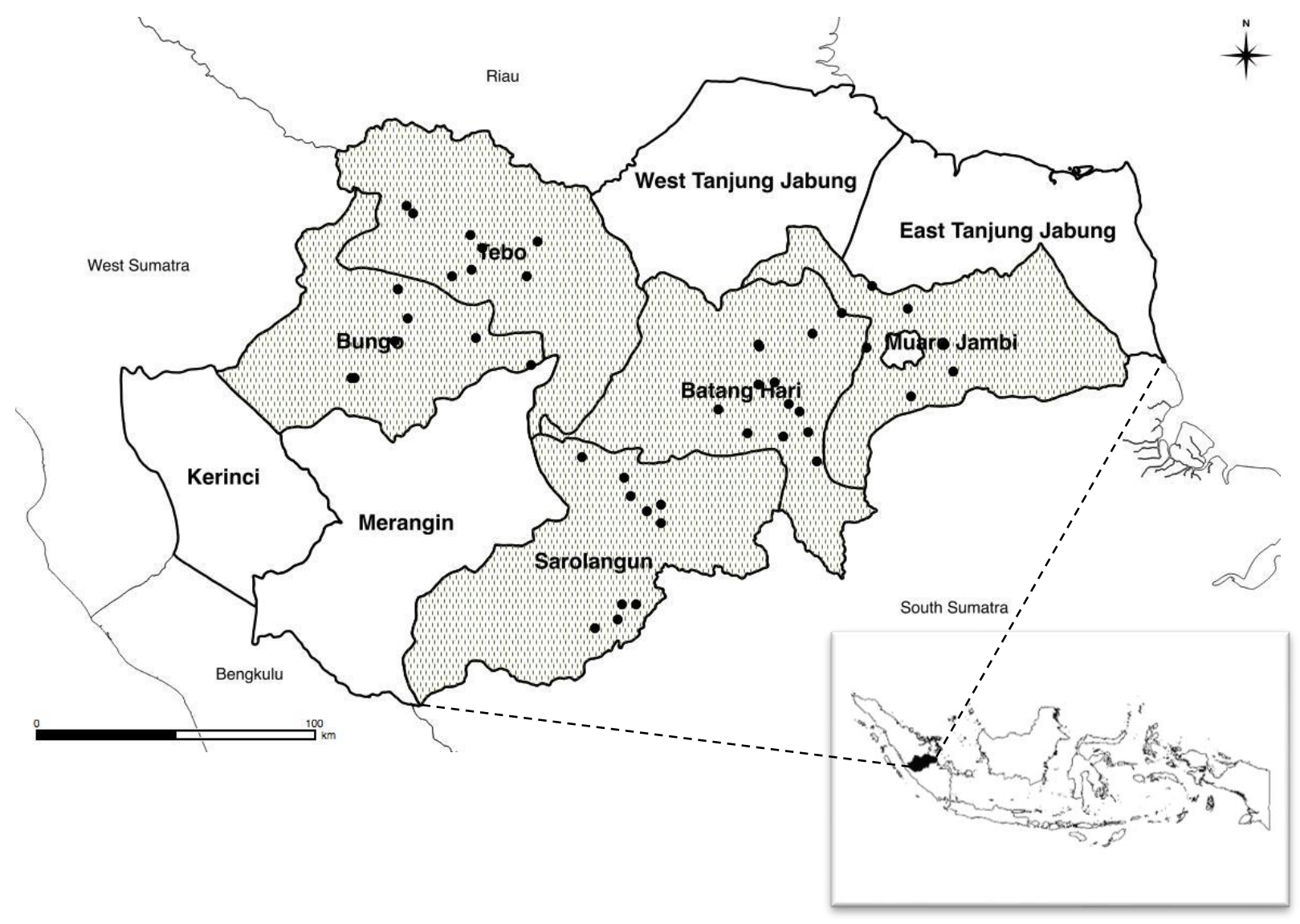

\section{Figure 1 Location of villages in Jambi and location of Jambi in Indonesia}

Notes: Thicker lines in the big map indicate regency delimiters. Shaded areas are lowland regencies that were selected purposively for this study. Dots refer to the villages where the survey was conducted.

In 2015 and 2018, those 701 households were revisited. For several reasons, mostly because of death and outmigration, there were $6 \%$ and $4.5 \%$ attrition levels in 2015 and 2018, respectively. Even though the attrition levels are relatively small, we ran a simple probit model to test for possible attrition bias by employing variables that might be relevant, such as the age and education of the household head, the types of crops grown, farm size, migration background, and household expenditures. The results show that none of these variables are significantly correlated with attrition except for the household head's age. There is a higher chance for households with older household heads to drop out on the next survey round due to sickness and death. To replace the unavailable households, we randomly selected other farm households in the same villages. 
The survey was conducted through face-to-face interviews by local assistants with direct supervision by the researchers themselves. The interviews were conducted in Bahasa Indonesia or sometimes in local languages that were spoken in Jambi, such as Bahasa Melayu and Bahasa Jawa. As a guideline, we used a carefully-designed structured questionnaire that asks about household socioeconomic characteristics, farm activities including input and output, off-farm activities, and household consumption, including food and non-food consumption (see Appendix). Through this questionnaire, we can see the adoption of oil palm by our samples across the year. The interview was usually conducted with the household head, sometimes with other household members' help, or whoever knows the answer best. Adult women often answered the consumption part of the interview, especially the details related to food consumption.

The local assistants were trained intensively at the University of Jambi. The questionnaire was tested with farmers who live in villages nearby Jambi City. In 2012 and 2015, the researchers used a paper-based questionnaire. In 2018, the questionnaire was converted to a tablet-based one. A tablet-based questionnaire reduces some possible human errors during the interview, for example, by providing error-messages and hints when illogical answers are entered. Therefore, mistakes can be fixed immediately during the interview session. For the researchers, a tabletbased survey allows them to complete the survey faster and more efficiently because some timeintensive activities are cut, such as later data entry after completing the survey itself.

\subsection{Outline of the dissertation}

This dissertation is organized as follows. Chapter 2 is the first essay, analyzing the associations of oil palm cultivation with nutrition and gender roles. Chapter 3 presents the second essay, exploring the role of oil palm cultivation for structural transformation of agriculture. The third essay is presented in Chapter 4, where the effects of oil palm cultivation on smallholder farm households' wellbeing are examined. Chapter 5 summarizes the main findings and discusses policy implications, limitations of the research, and future research recommendations. The farm household questionnaire that was used in the 2018 survey is attached in the Appendix. 


\title{
2 Land-use change, nutrition, and gender roles in Indonesian farm households ${ }^{1}$
}

\begin{abstract}
Many tropical countries are experiencing massive land-use change with profound environmental and socioeconomic implications. In Indonesia, oil palm cultivation is rapidly expanding at the expense of more traditional crops - such as rubber and rice - and forest land. While environmental effects of the oil palm boom were analyzed in many studies, much less is known about social effects. Here, we analyze how oil palm cultivation by smallholder farmers is associated with nutrition through changing income and gender roles. The analysis uses panel data collected in Jambi Province, Sumatra, one of the hotspots of Indonesia's recent oil palm boom. Regression models show that oil palm cultivation is positively associated with nutrition and dietary quality. These associations are related to income gains that improve smallholders' access to nutritious foods from the market. Oil palm requires less labor than traditional crops, so a switch to oil palm could potentially free family labor for off-farm economic activities. We find that oil palm cultivation is positively associated with off-farm employment of male but not female household members, which may be related to unequal opportunities and social norms. Independent of oil palm cultivation, female off-farm employment is positively associated with nutrition, even after controlling for household income.
\end{abstract}

Keywords: Oil palm; Smallholder livelihoods; Gender roles; Nutrition; Dietary quality; Offfarm employment

\footnotetext{
${ }^{1}$ This essay has been published as: Chrisendo, D., Krishna, V. V., Siregar, H., Qaim, M. 2020. Land-use change, nutrition, and gender roles in Indonesian farm households. Forest Policy and Economics 118, 102245. https://doi.org/10.1016/j.forpol.2020.102245 DC developed the research idea, curated the data, implemented the econometric modelling, conducted the analyses, wrote the first draft of the essay, and revised the essay. VVK conducted the survey, developed the research idea, and revised the essay. HR revised the essay. MQ developed the research idea, revised the essay, and supervised.
}

Acknowledgement: The authors are grateful for valuable comments from Meike Wollni on the earlier version of the essay at the DARE doctoral seminar. The authors also thank Christoph Kubitza for feedback during the data curation, and the editors and two anonymous reviewers for helpful comments and suggestions to improve this paper. 


\subsection{Introduction}

Many countries in tropical regions are experiencing massive land-use change. In Indonesia and other countries of Southeast Asia, the expansion of oil palm at the expense of more traditional crops and forest land is particularly noteworthy (Feintrenie et al., 2010; Byerlee et al., 2017; Euler et al., 2016; Kubitza et al., 2018b). Indonesia is now the largest producer of palm oil in the world. Between 2005 and 2015, Indonesia's area under oil palm more than doubled from around 5 million hectares to over 11 million hectares (Ministry of Agriculture Indonesia, 2016). The rapid expansion of oil palm has been criticized on environmental grounds, as it is associated with deforestation, loss of biodiversity, greenhouse gas emissions, and other environmental problems (Marlier et al., 2015; Susanti \& Maryudi, 2016; Grass et al., 2020). There are also social concerns, often related to land tenure conflicts (Hidayat et al., 2018). Government concessions for large companies to grow oil palm sometimes overlap with land for which local communities have informal usufruct rights under customary law (Krishna et al., 2017b). On the other hand, the oil palm boom has positive effects, as it contributes to economic growth, poverty reduction, and broader rural development (Rist et al., 2010; Zen et al., 2016; Bou Dib et al., 2018a; Bou Dib et al., 2018b; Purnomo et al., 2018; Qaim et al., 2020).

In Indonesia, oil palm is not only cultivated on large company plantations; around $40 \%$ of the palm oil is produced by smallholder farmers (Gatto et al., 2015; Euler et al., 2016). These farmers benefit economically because oil palm is more profitable than the production of food crops and less labor demanding than traditional cash crops like rubber (Euler et al., 2017; Kubitza et al., 2018a). Beyond profits and income, effects of oil palm cultivation on other social dimensions of household welfare - such as nutrition - have hardly been analyzed up till now. Oil palm could potentially threaten food security if it replaces the cultivation of local food crops and thus decreases local food availability (Cassman \& Liska, 2007; Li, 2015). On the other hand, oil palm cultivation may also improve food security and nutrition through income gains and thus better economic access to nutritious foods (Sibhatu, 2019).

Here, we analyze the association between oil palm cultivation and nutrition in smallholder farm households. Nutrition effects may be channeled through various mechanisms, including changes in food production, income, and gender roles within the household. We develop a conceptual framework and test a set of concrete research hypotheses related to these mechanisms. The empirical analysis uses two rounds of household panel data collected in Jambi Province, Sumatra, one of the hotspots of Indonesia's recent oil palm boom. 


\subsection{Background}

\subsubsection{Oil palm expansion in Jambi}

During the first half of the twentieth century, forest, rice, and natural rubber were the main landuse types in Jambi. Rice was mainly produced for subsistence, while rubber was the dominant cash crop. Rubber was initially grown in agroforestry systems, but more intensively-cultivated rubber monocultures gained in importance over time (Gatto et al., 2015; McCarthy \& Zen, 2016). Until the late-1960s, oil palm did not play an important role in Jambi, but in the 1970s and 1980s, several large oil palm plantations were established by state-run companies. The Indonesian government also actively encouraged smallholder farmers to participate in oil palm cultivation (Zen et al., 2016; Gatto et al., 2017). Initially, smallholder oil palm cultivation was associated with the government's transmigration programs, which were implemented to reallocate people from overpopulated Java to scantly-populated islands such as Sumatra (Fearnside, 1997). Transmigrant families were given some land for settlement and the production of food and cash crops, especially oil palm. Hence, transmigrants were the first smallholders in Jambi to cultivate oil palm, whereas the autochthonous population - mainly from the Melayu tribe - continued to cultivate rubber as their traditional cash crop (Zen et al., 2016).

During the transmigration programs in the 1980s and early-1990s, most oil palm-cultivating smallholders had contracts with large plantation companies under the so-called nucleus estate and smallholder (NES) schemes (Feintrenie et al., 2010; McCarthy \& Zen, 2016). Through the NES schemes, smallholders received subsidized credit, which was necessary because the establishment of oil palm plots is a capital-intensive investment. Some of the autochthonous communities were also offered similar contracts and credits when they were willing to give up some of the community lands for company plantations (Rist et al., 2010). While these arrangements between palm oil companies and autochthonous communities worked well in some situations, there are also reported cases of conflict over land rights and over-indebtedness of farmers who were unable or unwilling to repay the credits received (Li, 2015; Levang et al., 2016; Zen et al., 2016). Often the contract and credit conditions were not sufficiently transparent for the farmers involved (Gatto et al., 2017).

Since the early-2000s, contracts between oil palm companies and smallholder farmers have lost in importance, also because most of the related government subsidies had been phased out in the 1990s. The number of oil palm smallholders in Jambi continues to rise, but nowadays, most 
smallholders cultivate oil palm independently without company contracts (Qaim et al., 2020). Smallholders either use previous forest or fallow land, or they convert old rubber plantations for the establishment of new oil palm plots (Gatto et al., 2015; Grass et al., 2020). Over the last 20 years, many rubber farmers entered the oil palm business or switched entirely to oil palm, because oil palm requires less labor than rubber and leads to higher household incomes (Krishna et al., 2017a). However, access to capital remains a constraint for some, so oil palm contributes to rising inequality among farm households in Jambi (McCarthy et al., 2012; Euler et al., 2017; Bou Dib et al., 2018a).

\subsubsection{Gender, agriculture, and nutrition}

Women's roles within households and societies are known to be critical factors for food security and nutrition (Ruel \& Alderman, 2013; Malapit \& Quisumbing, 2015; Niehof et al., 2018). Strengthening women's roles and gender equity is typically associated with better nutritional outcomes for the family as a whole, and children in particular (Ruel \& Alderman, 2013). However, gender roles can be very diverse, as they depend on a multitude of socioeconomic conditions. This is especially true in Indonesia, with its vast socioeconomic and ethnic diversity (Niehof et al., 2018; Pangaribowo et al., 2019). Here, we discuss a few general aspects that seem to be of particular importance in the context of Indonesia's recent oil palm boom.

In rural Indonesia, women are traditionally actively involved in agricultural work and farm management. However, women's involvement can vary depending on farm size and the types of crops grown (Villamor et al., 2015). When households start cultivating oil palm, women's involvement in farming often tends to shrink. On the one hand, the most labor-intensive activity in oil palm cultivation is harvesting, which is mostly done by men as it requires substantial physical strength. On the other hand, there are also institutional features that contribute to shrinking women's involvement. In the NES schemes with palm oil companies, women are often excluded because of prevailing gender norms. Women are generally not considered as the head of the household and are therefore restricted in carrying out business negotiations (O'Shaughnessy, 2009; de Vos \& Delabre, 2018). In some cases of oil palm contracting, women also lost their control over land and other productive assets (Park et al., 2015; Elmhirst et al., 2017).

In addition to activities on the family farm, rural women are also involved in off-farm economic activities. International research shows that women's involvement in off-farm employment can 
be associated with greater female decision-making power within the household (Majlesi, 2016; Debela et al., 2020), and that greater female decision-making power is associated with better family nutrition and health (Ruel \& Alderman, 2013). However, this also depends on the educational level and the type of employment. In rural Indonesia, women's educational levels are often low, and their access to better-paid jobs is limited. Under these conditions, women in poor households often pursue off-farm employment primarily as an economic necessity and opt-out when household incomes increase (Schaner \& Das, 2016). The time spent by women at work is also an important variable with possible nutrition implications. High levels of female off-farm labor supply can have negative consequences for family nutrition, as women working away from home may be less involved in household food preparation due to time constraints (Johnston et al., 2018; Debela et al., 2020).

\subsection{Conceptual framework}

We aim to analyze how oil palm cultivation by smallholders is associated with household nutrition, considering possible mechanisms such as changes in income and gender roles. We first explain possible mechanisms before developing a set of concrete research hypotheses.

\subsubsection{Possible mechanisms}

Ruel \& Alderman (2013) discuss different mechanisms of how agriculture can influence nutrition in smallholder farm households. We discuss these mechanisms with a particular focus on oil palm cultivation. The possible mechanisms are summarized in Figure 2. A first mechanism is through own food production. Smallholder farm households are often subsistence-oriented, meaning that much or their food consumption comes from own farm production. In subsistence situations, the types of crops grown on the farm directly affect household diets and nutrition. When household resources are limited, the adoption of a cash crop, such as oil palm, will likely reduce the extent and diversity of food production on the farm, which may lead to a negative partial effect on family nutrition (Li, 2015).

A second mechanism is related to food prices in the local context. More cash cropping may decrease food production, not only on the individual farm but also regionally (Santika et al., 2019a). This may increase local food prices, especially when local food markets are not well 
integrated with national or international markets. Higher food prices make food less affordable for market consumers, including farm and non-farm households (Anderman et al., 2014).

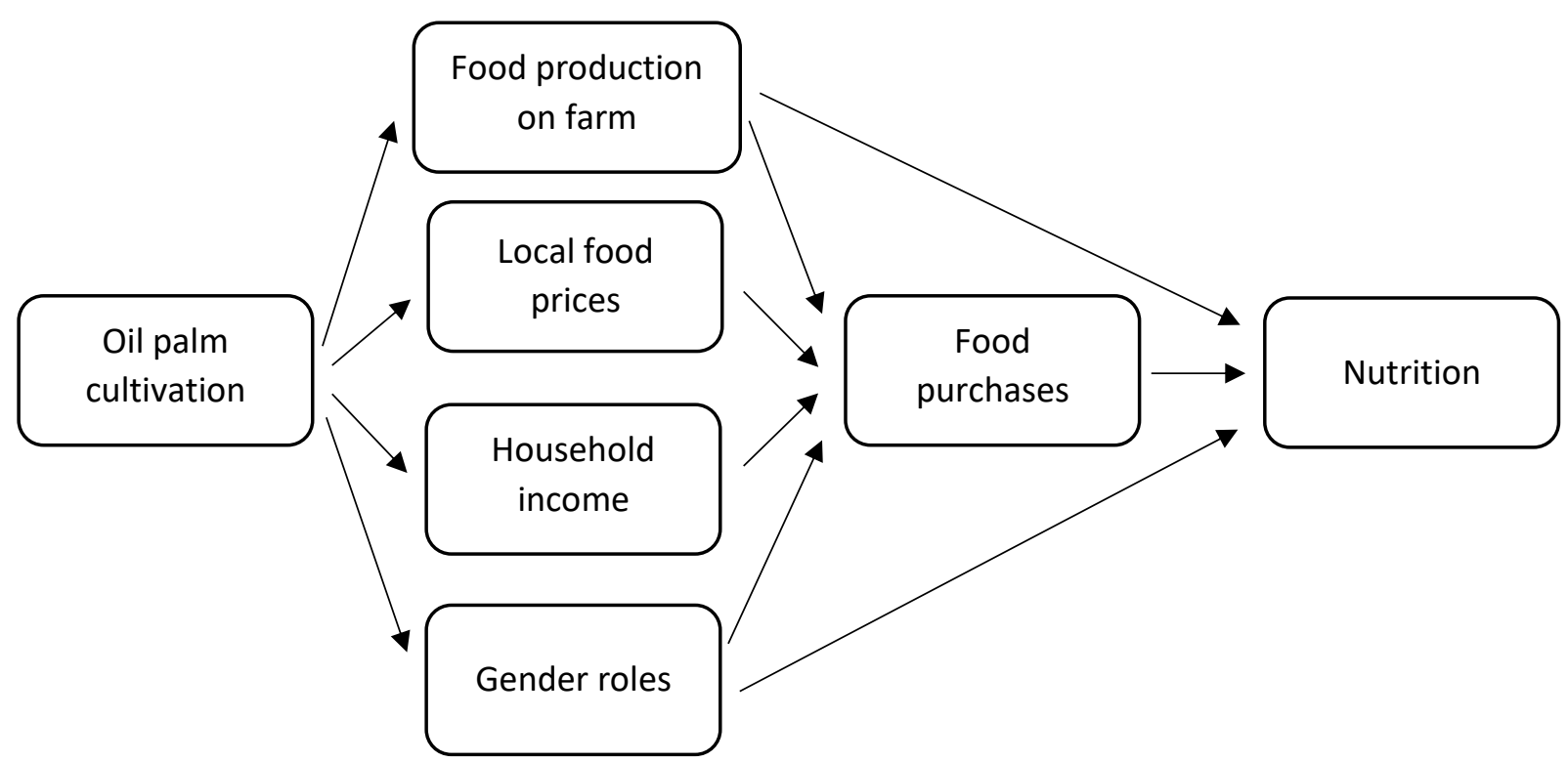

Figure 2 Possible mechanisms of the association between smallholder oil palm cultivation and nutrition

A third mechanism is through possible changes in household income resulting from oil palm cultivation. Several studies with data from Indonesia showed that the adoption of oil palm by smallholder farmers can lead to significant income gains (Rist et al., 2010; Euler et al., 2017; Krishna et al., 2017a; Kubitza et al., 2018a). The additional cash income can improve households' access to food and dietary quality from the market (Sibhatu, 2019).

A fourth mechanism is related to the possibility of changing gender roles within the household. Gender roles matter for nutrition in at least three ways, namely women's social status and empowerment, women's time allocation, and women's health status (Ruel \& Alderman, 2013; Lecoutere \& Jassogne, 2019). Agricultural commercialization - meaning a shift from subsistence farming towards producing cash commodities - can be associated with a loss in female financial autonomy because income from cash commodities is often controlled by men (Chiputwa \& Qaim, 2016; Tavenner \& Crane, 2018). The exclusion of women in cash crop cultivation can also decrease their control over resources and assets, which influences their decision-making power within the households (de Vos \& Delabre, 2018). Loss in female decision-making power may entail a negative partial effect on household nutrition, as women 
tend to have a stronger emphasis than men on family health and nutrition (Taridala et al., 2010; Debela et al., 2020).

In terms of women's time allocation, oil palm is known to be more capital-intensive but less labor-intensive than traditional agricultural crops grown in Indonesia (Feintrenie et al. 2010; Euler et al., 2017). Hence a switch to oil palm could free labor time and enable household members to get involved in other economic activities, including off-farm employment. As mentioned above, female off-farm employment could increase women's decision-making power and thus contribute to improved nutrition (Majlesi, 2016; Debela et al., 2020), even though this also depends on the type of employment, possible time constraints, and other socioeconomic conditions.

In terms of women's health, agricultural and non-agricultural employment can have various health implications. For instance, $\mathrm{Li}$ (2015) argued that women working in oil palm plantations suffer several health risks, such as physical injury or respiratory problems associated with exposure to agrochemicals and other toxic substances. Poor health can affect women's nutritional status directly.

\subsubsection{Research hypotheses}

The first and overarching hypothesis that we want to test is that oil palm cultivation is positively associated with household nutrition and dietary quality. This will be tested with regression models of the following type:

$$
N_{i}=\alpha_{0}+\alpha_{1} O P_{i}+\alpha_{2} Z_{i}+\varepsilon_{i}
$$

where $N_{i}$ is a measure of nutrition (we will use different indicators, as explained below) of farm household $i, O P_{i}$ is a dummy variable that captures whether or not household $i$ is involved in oil palm cultivation, $Z_{i}$ is a vector of control variables, and $\varepsilon_{i}$ is a random error term. In this model, we are particularly interested in $\alpha_{1}$. A positive and significant estimate for $\alpha_{1}$ would lend support to the first hypothesis.

We develop additional hypotheses to analyze some of the mechanisms discussed above. The mechanisms related to own food production and food market prices are relevant in general, but do not apply to the particular context in Jambi. Food crop production in Jambi was very low even before the oil palm boom started. As discussed above, rubber has been the dominant crop grown in Jambi already for many decades, and rubber is a pure cash crop itself. Oil palm has 
partly replaced rubber, or new plantations were established on fallow and forest land (Clough et al., 2016; Drescher et al., 2016). The substitution of oil palm for food crops was hardly observed in Jambi. Most farm households in Jambi buy all of their food from the market, regardless of whether or not they are involved in oil palm cultivation (Sibhatu et al., 2015). Furthermore, food markets in Jambi are well integrated with other national and international markets, so that food prices are not primarily determined by what is cultivated locally.

Concerning the income mechanism, previous studies with the same farm survey data from Jambi showed that oil palm cultivation contributes to significant income gains in smallholder households (Euler et al., 2017; Kubitza et al., 2018a). We build on these previous results, but additionally test the hypothesis that higher incomes are associated with better nutrition and dietary quality. This hypothesis is tested with regression models of the following type:

$$
N_{i}=\beta_{0}+\beta_{1} I N C_{i}+\beta_{2} Z_{i}+\varepsilon_{i}
$$

where $I N C_{i}$ is the income of farm household $i$, and the other variables are as defined before. A positive and significant estimate for $\beta_{1}$ would confirm that additional household income is associated with improved nutrition and dietary quality.

Concerning the gender role mechanism, we do not expect oil palm cultivation to affect gendered control of cropping income. While the income from oil palm is primarily controlled by male household members (Elmhirst et al., 2017), the same is true for the income from rubber. Both crops are pure cash crops in Indonesia, for which the marketing is primarily managed by male household members. However, rubber is more labor-intensive than oil palm (Krishna et al., 2017a), so a switch of crops may be associated with re-allocation of household labor time. We test the hypothesis that oil palm cultivation is associated with a lower amount of household labor involved in farming than rubber cultivation. Moreover, as we want to understand possible implications for gender roles, we differentiate between female and male labor, estimating models of the following type:

$$
\begin{aligned}
& F L_{i}=\gamma_{0}+\gamma_{1} O P_{i}+\gamma_{2} Z_{i}+\varepsilon_{i} \\
& M L_{i}=\delta_{0}+\delta_{1} O P_{i}+\delta_{2} Z_{i}+\varepsilon_{i}
\end{aligned}
$$

where $F L_{i}$ and $M L_{i}$ are the amounts of female and male household labor involved in farming, respectively. Negative estimates for $\gamma_{1}$ and $\delta_{1}$ would mean that a switch from rubber to oil palm frees female and male household labor time. 
In the next step, and related to a possible reduction in labor time on the farm, we test the hypothesis that oil palm cultivation is associated with higher off-farm employment:

$$
\begin{aligned}
& F O F_{i}=\theta_{0}+\theta_{1} O P_{i}+\theta_{2} Z_{i}+\varepsilon_{i} \\
& M O F_{i}=\vartheta_{0}+\vartheta_{1} O P_{i}+\vartheta_{2} Z_{i}+\varepsilon_{i}
\end{aligned}
$$

where $F O F_{i}$ and $M O F_{i}$ denote female and male off-farm employment, respectively. Positive $\theta_{1}$ and $\vartheta_{1}$ coefficients would indicate that oil palm cultivation is positively associated with female and male off-farm employment, respectively.

Finally, we test the hypothesis that off-farm employment is positively associated with nutrition and dietary quality:

$$
N_{i}=\rho_{0}+\rho_{1} F O F_{i}+\rho_{2} M O F_{i}+\rho_{3} Z_{i}+\varepsilon_{i}
$$

If female off-farm employment is positively associated with women's decision-making power within the household, and women's decision-making power has a positive effect on nutrition, we would expect a positive coefficient $\rho_{1}$, also after controlling for household income.

\subsection{Materials and methods}

\subsubsection{Farm household survey}

We surveyed farm households in Jambi Province on the island of Sumatra, Indonesia. Our survey was implemented in two rounds, in 2012 and 2015. Sample farm households were selected in 2012 through a multi-stage sampling procedure. We first selected five regencies that cover the largest part of Jambi’s lowland areas: Batanghari, Bungo, Muaro Jambi, Sarolangun, and Tebo. In each of these regencies, we randomly selected four districts. In each district, we randomly selected two villages, resulting in a total of 40 villages. In each of these 40 villages, we randomly selected 6-25 farm households, depending on the village size. This resulted in a sample of 598 households, which is representative of farm households in Jambi's lowland areas, where most of the Province's oil palm and rubber are grown.

Besides, we collected data from 103 farm households in five other, purposively selected villages in Jambi. In these five villages, we are involved in joint research with colleagues from various natural science disciplines (Drescher et al., 2016; Grass et al., 2020). For the empirical analysis, we use the entire sample of 701 households from 45 villages but control for observations from non-randomly selected villages in all regression models. For the 2015 survey round, the same 
701 households were targeted, but due to attrition, 41 households had to be replaced through additional random selection in the same villages. For the analysis, we use the unbalanced panel, including all observations from both survey rounds. ${ }^{2}$

The survey involved face-to-face interviews with the household head (or, in some cases, the spouse) using a carefully designed and pre-tested structured questionnaire. The interviews were conducted in Bahasa Indonesia by local enumerators that were trained and supervised by the researchers. The questionnaire included sections on general household characteristics, farming activities, employment on and off the farm, and household food and non-food consumption. Further details of the data and the definition of key variables are explained below.

\subsubsection{Measuring nutrition}

Nutrition can be measured in several ways, including anthropometric measures and food consumption based surveys (de Haen et al., 2011). Here we use food consumption data from a household-level recall that was included in the survey questionnaire. We used a 7-day recall period and a list of 120 different food items tailored to local consumption habits. Seven-day food recall data collected at the household level have become a popular tool to analyze diets and nutrition (Zezza et al., 2017). Household consumption data cannot provide precise measures of individual-level food intakes, but research shows that household-level dietary indicators are correlated with individual-level indicators (Sununtnasuk \& Fiedler, 2017; Fongar et al., 2019). One general problem that relates to both household- and individual-level data is that food consumption during a short recall period does not reflect seasonal variation. However, as mentioned, farm households in Jambi purchase almost all of their food from the market. Rubber and oil palm are both harvested all year round, which leads to a stable stream of cash revenues. Thus, seasonal variation in food consumption is expected to be small in this context.

A first dietary indicator that we calculate based on the household-level food consumption data is a dietary diversity score (DDS). DDS counts the number of different food groups consumed over a given period of time (in our case, the 7-day recall period) and has become a widely used and straightforward-to-construct indicator for dietary analysis (FAO, 2011; Sibhatu \& Qaim,

\footnotetext{
${ }^{2}$ While the attrition rate of $6 \%$ is relatively low, we tested for possible attrition bias by running a probit model with an attrition dummy as dependent and several socioeconomic variables observed in 2012 (oil palm cultivation, farm size, education, living standard, etc.) as independent variables. Results are shown in Table A.1 in the Appendix. None of the socioeconomic variables is significant, except for age of the household head. Older farmers were somewhat more likely to drop out due to death or disease. This does not lead to bias in our sample, as the replacement of old farmers is according to the normal generational cycle.
} 
2018). Depending on the intention, different food group classifications can be used to construct the DDS. We use a classification with nine food groups as recommended for the women's dietary diversity score (FAO, 2011), namely (1) starchy staples; (2) dark green leafy vegetables; (3) other vitamin-A rich fruits and vegetables; (4) other fruits and vegetables; (5) organ meat; (6) meat and fish; (7) eggs; (8) legumes, nuts and seeds; (9) milk and milk products. A higher DDS score is an indicator of higher dietary diversity.

One disadvantage of DDS is that it counts food groups whenever a food item belonging to the group was consumed, even if the quantity consumed was very small. However, certain minimum quantities are needed in order to prevent nutritional deficiencies. Therefore, in addition to DDS, we calculate the quantities of calories and certain micronutrients consumed by sample households. For micronutrients, we concentrate on vitamin A, iron, and zinc, because deficiencies in these nutrients are widespread in many developing countries with severe adverse health implications (Development Initiatives, 2018). This is also true in Jambi. While calorie undernutrition is no longer considered a major problem, low dietary quality and micronutrient deficiencies are still widespread in Jambi (Dinas Kesehatan Jambi, 2016). We used food composition tables for Indonesia (Berger et al., 2013) supplemented by international references (e.g., USDA, 2016) to convert the food quantities consumed to calorie and micronutrient consumption. The 7-day quantities were converted to daily values and divided by the number of male adult equivalents (AE) living in each household to allow comparison across households of different size.

\subsubsection{Measuring other key variables}

Beyond nutrition, other key variables in our analysis are household income, gendered labor time and employment, and several other socioeconomic controls. We proxy household income by annual household expenditures, including the combined value of all foods and non-food goods and services consumed by household members. This is a common approach in the development economics literature because expenditures are usually a more precise indicator of household living standard than income (Deaton, 1997). Annual expenditures are expressed in Indonesian Rupiah (IDR) per AE.

Female and male labor time are captured for the entire farm and also separately for rubber and oil palm as the main agricultural enterprises. In the survey, labor input questions for the family and paid laborers were asked for the last 12 months. In this analysis, we only consider the 
number of hours worked by female and male household members. For off-farm activities, we do not have data on the number of hours worked, but we know from the survey responses who was employed (or self-employed) in off-farm activities during the last 12 months. We use this information to create dummy variables for female and male off-farm employment.

Socioeconomic controls that we use in the regression models include farm size (measured in hectares), household size (female and male adults and children), age and educational levels of male and female adults (years of schooling), ethnicity (dummy for the autochthonous Melayu population), and market distance (measured in $\mathrm{km}$ ), among others.

\subsubsection{Statistical analysis}

We start the analysis by comparing descriptive statistics between different groups of households. Farm households in Jambi either grow rubber, or oil palm, or both, which is why we subdivide the sample into these three groups for the descriptive comparisons. We compare household expenditures, nutrition and dietary indicators, on-farm labor time, and off-farm employment between these three groups to get a first impression of the potential effects of oil palm cultivation.

In addition to the descriptive comparisons, we run the regression models described above to test the research hypotheses. We use two dummy variables to characterize oil palm cultivation: one for households that only cultivate oil palm, and the other for households that cultivate oil palm in addition to rubber. Hence, the reference group is households that only cultivate rubber. The models include observations from both survey rounds (2012 and 2015) and are estimated with random effects panel estimators.

To reduce possible issues of endogeneity of oil palm cultivation, we also tried fixed effects estimators, but these did not result in efficient estimates due to the small variation in oil palm cultivation within households between 2012 and 2015. As an alternative robustness check, we run models where the outcome variables in 2015 are regressed on oil palm cultivation and other explanatory variables in 2012. This approach does not eliminate endogeneity, but it reduces possible issues of reverse causality. That oil palm cultivation improves farm household living standards was shown with the same data from Jambi and instrumental variable models by Euler et al. (2017) and Krishna et al. (2017a). Due to different outcome variables in this study, we 
were not able to identify valid instruments for oil palm cultivation. ${ }^{3}$ Therefore, the estimates reported here should be interpreted as associations, not as causal effects.

\subsection{Results and discussion}

2.5.1 Household expenditures and dietary quality with and without oil palm

Table 1 shows descriptive statistics for the three groups of farm households, namely those with only rubber (column 1), with only oil palm (column 2), and with oil palm and rubber combined (column 3). Households with only rubber and only oil palm have similar farm sizes, whereas households that cultivate both crops have significantly larger farms. As expected, households with oil palm cultivation are significantly wealthier (higher household consumption expenditures) than households that only grow rubber. Table 1 also shows significant differences between the groups in terms of the dietary indicators. Households that cultivate oil palm have higher dietary diversity and higher calorie and micronutrient consumption than households that only cultivate rubber.

Table 1 Expenditures and dietary quality by farm household type

\begin{tabular}{|c|c|c|c|}
\hline & $\begin{array}{c}(1) \\
\text { Only rubber } \\
(n=833)\end{array}$ & $\begin{array}{c}(2) \\
\text { Only oil palm } \\
(\mathrm{n}=194)\end{array}$ & $\begin{array}{l}(3) \\
\text { Oil palm and rubber } \\
(n=323)\end{array}$ \\
\hline Average size of farm (ha) & $\begin{array}{c}3.52 \\
(5.06)\end{array}$ & $\begin{array}{c}3.39 \\
(3.12)\end{array}$ & $\begin{array}{c}8.83 * * * \\
(13.15)\end{array}$ \\
\hline Household expenditure (million & 13.01 & $15.65 * * *$ & $18.86 * * *$ \\
\hline IDR/AE/year) ${ }^{\mathrm{a}}$ & $(16.75)$ & $(10.88)$ & $(17.45)$ \\
\hline Dietary diversity score (0-9) & $\begin{array}{c}6.56 \\
(1.27)\end{array}$ & $\begin{array}{c}6.97 * * * \\
(1.01)\end{array}$ & $\begin{array}{c}7.00 * * * \\
(1.21)\end{array}$ \\
\hline Calories (kcal/AE/day) & $\begin{array}{c}2793.60 \\
(1312.04)\end{array}$ & $\begin{array}{c}3114.73 * * * \\
(1344.07)\end{array}$ & $\begin{array}{c}3425.93 * * * \\
(1825.84)\end{array}$ \\
\hline Iron (mg/AE/day) & $\begin{array}{c}17.29 \\
(11.80)\end{array}$ & $\begin{array}{c}20.75 * * * \\
(11.49)\end{array}$ & $\begin{array}{c}22.03 * * * \\
(15.44)\end{array}$ \\
\hline Zinc (mg/AE/day) & $\begin{array}{c}9.93 \\
(4.71)\end{array}$ & $\begin{array}{c}11.56 * * * \\
(5.78)\end{array}$ & $\begin{array}{c}12.31 * * * \\
(7.45)\end{array}$ \\
\hline Vitamin $\mathrm{A}(\mu \mathrm{g} / \mathrm{AE} /$ day $)$ & $\begin{array}{c}941.52 \\
(1557.37)\end{array}$ & $\begin{array}{c}1132.84 \\
(1454.13)\end{array}$ & $\begin{array}{c}1350.17 * * * \\
(1998.66)\end{array}$ \\
\hline
\end{tabular}

Notes: Mean values for the pooled sample, including the 2012 and 2015 survey rounds, are shown with standard deviations in parentheses. ${ }^{\text {a }}$ Expenditures in 2015 were deflated by using the consumer price index for Indonesia to make values comparable across survey rounds (in 2015, 1 US\$ was equivalent to IDR 13,401). *** Mean values are significantly different from those in column (1) at the $1 \%$ level.

\footnotetext{
${ }^{3}$ None of the determinants of oil palm cultivation satisfied the exlusion restriction for the nutrition, expenditure, and gendered employment variables. As indicated by Kubitza \& Krishna (2020), broadly-defined outcome variables, such as nutrition or dietary diversity, are often influenced by a large number of observed and unobserved factors, so that it can be difficult to identify valid instruments.
} 


\subsubsection{Labor allocation with and without oil palm}

Table 2 compares household labor input in oil palm and rubber. On average, the household labor input is $80 \%$ lower in oil palm than rubber. ${ }^{4}$ This large difference is due to quite different production and harvesting processes between the two crops. Rubber trees are usually tapped every day, so labor input is constantly required. Male and female household members are both involved in rubber cultivation and tapping. In contrast, harvesting in oil palm fields is conducted only once every two weeks. Manually harvesting the heavy oil palm fruit bunches is physically demanding and, therefore, often carried out by male laborers.

Table 2 Household labor input in oil palm and rubber

\begin{tabular}{lcc}
\hline & $\begin{array}{c}\text { Labor time in oil palm } \\
\text { (hours/ha/year) }\end{array}$ & $\begin{array}{c}\text { Labor time in rubber } \\
\text { (hours/ha/year) }\end{array}$ \\
\hline Total household labor & 157.09 & $822.94 * * *$ \\
& $(260.80)$ & $(1063.58)$ \\
Female household labor & 24.75 & $249.24 * * *$ \\
& $(68.31)$ & $573.70 * * *$ \\
Male household labor & 132.34 & $(808.91)$ \\
Number of observations & $(235.06)$ & 1158 \\
\hline
\end{tabular}

Notes: Mean values for the pooled sample, including the 2012 and 2015 survey rounds, are shown with standard deviations in parentheses. ${ }^{* * *}$ Mean values are significantly different at the $1 \%$ level.

In order to analyze whether the lower family labor requirement in oil palm is associated with a higher likelihood of off-farm employment, we compare off-farm employment rates between households with and without oil palm cultivation in Figure 3. Typical off-farm activities in the study region include employment in agriculture, processing, construction, transport, and education, or self-employment in trade and handicrafts. The likelihood of off-farm employment is significantly higher in households that only cultivate oil palm than in households that only cultivate rubber. The difference is not significant when households that only grow rubber are compared with households that cultivate both crops. However, this comparison is not very meaningful as households cultivating both crops have a larger landholding size (Table 1).

\footnotetext{
${ }^{4}$ In this study, we only look at household labor. Many of the farm households in our sample additionally employ paid laborers on their rubber and oil palm plots. Previous research with the same data showed that oil palm is generally less labor-intensive than rubber, reducing both household labor and paid labor employed per ha of land (Euler et al., 2017).
} 


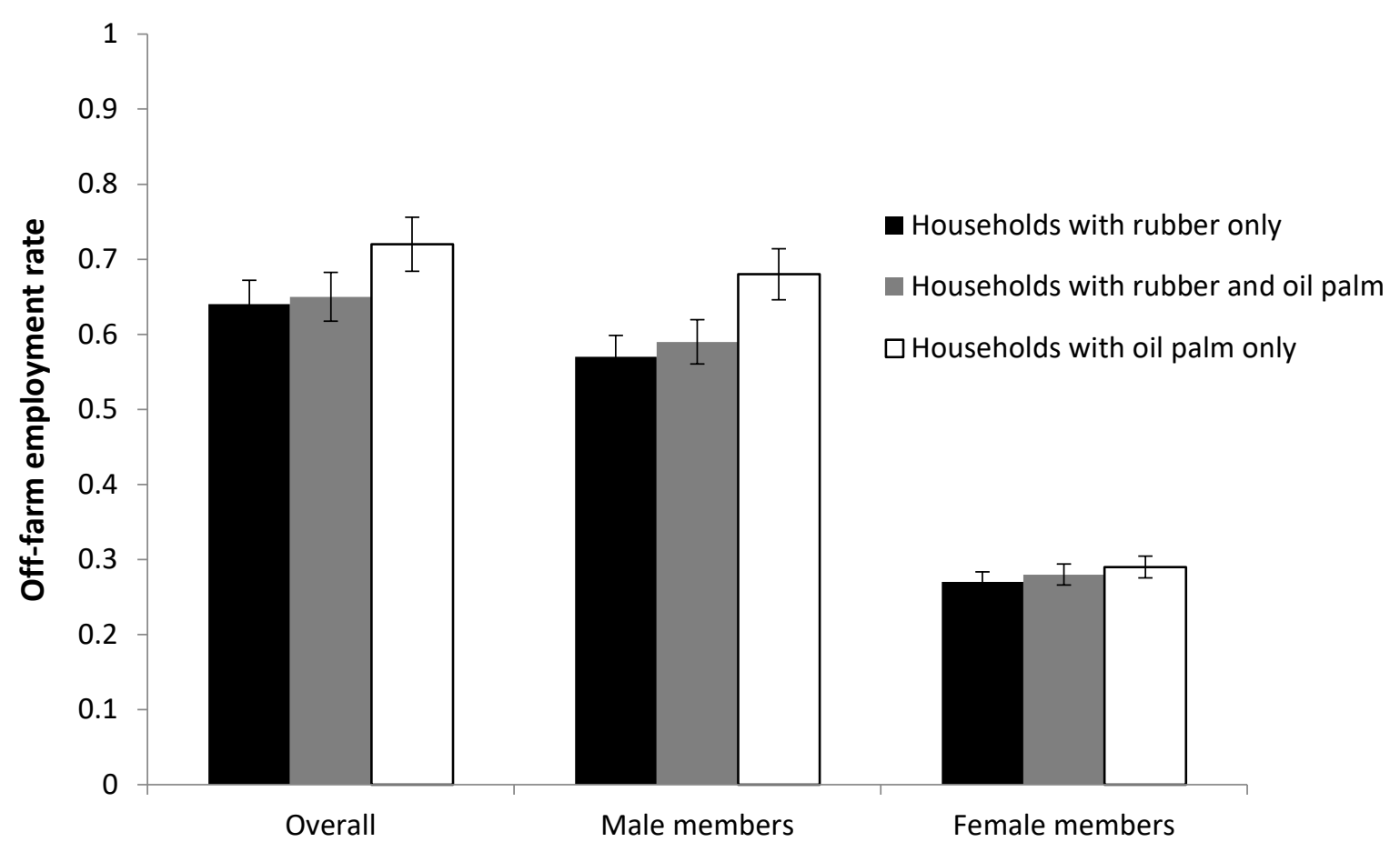

Figure 3 Gendered off-farm employment in households with and without oil palm

Note: Mean rates are shown with standard error bars.

Figure 3 reveals that most of the differences in off-farm employment are due to higher male employment rates in oil palm-cultivating households. For women, small differences are observed, but these are not statistically significant. In general, women are much less likely to have off-farm employment than men, which is not surprising in the local context. In rural Indonesia, due to human capital and cultural constraints, women have limited access to lucrative types of off-farm employment (Elmhirst et al., 2017; Schaner \& Das, 2016; Williams, 1990). Especially in poor households, women often work as unskilled laborers in agriculture, or they pursue irregular activities in the informal sector.

Table 3 analyzes possible links between off-farm employment and nutrition. When comparing households with and without off-farm employment, most of the dietary indicators are not significantly different (columns 1 and 2). Strikingly, however, the analysis in columns (3) and (4) shows that households with female off-farm employment have significantly better dietary quality than households where only male household members are employed. This gendered pattern could be related to women with own cash income from off-farm activities having greater financial autonomy within the household, which was also shown to lead to better family nutrition in other contexts (Taridala et al., 2010; Chiputwa \& Qaim, 2016). 
Table 3 Dietary quality in households with and without off-farm employment

\begin{tabular}{|c|c|c|c|c|}
\hline & \multicolumn{2}{|c|}{ All households } & \multicolumn{2}{|c|}{ Only with off-farm employment } \\
\hline & $\begin{array}{c}(1) \\
\text { Without off-farm } \\
\text { employment }\end{array}$ & $\begin{array}{c}(2) \\
\text { With off-farm } \\
\text { employment } \\
\end{array}$ & $\begin{array}{c}\text { (3) } \\
\text { Only male } \\
\text { employment }\end{array}$ & $\begin{array}{c}\text { (4) } \\
\text { At least one } \\
\text { female employed }\end{array}$ \\
\hline Dietary diversity score (0-9) & $\begin{array}{c}6.57 \\
(1.22)\end{array}$ & $\begin{array}{c}6.80 * * * \\
(1.24)\end{array}$ & $\begin{array}{c}6.67 \\
(1.28)\end{array}$ & $\begin{array}{c}7.00 * * * \\
(1.16)\end{array}$ \\
\hline Calories (kcal/AE/day) & $\begin{array}{c}2981.18 \\
(1520.53)\end{array}$ & $\begin{array}{c}2963.04 \\
(1434.54)\end{array}$ & $\begin{array}{c}2837.45 \\
(1251.61)\end{array}$ & $\begin{array}{c}3133.61 * * * \\
(1637.17)\end{array}$ \\
\hline Iron (mg/AE/day) & $\begin{array}{c}19.27 \\
(12.98)\end{array}$ & $\begin{array}{c}18.54 \\
(12.61)\end{array}$ & $\begin{array}{c}17.35 \\
(10.74)\end{array}$ & $\begin{array}{c}20.16 * * * \\
(14.63)\end{array}$ \\
\hline Zinc (mg/AE(day) & $\begin{array}{l}10.76 \\
(6.24)\end{array}$ & $\begin{array}{l}10.61 \\
(5.35)\end{array}$ & $\begin{array}{l}10.18 \\
(4.44)\end{array}$ & $\begin{array}{c}11.2 * * * \\
(6.34)\end{array}$ \\
\hline Vitamin A ( $\mu \mathrm{g} / \mathrm{AE} /$ day $)$ & $\begin{array}{c}966.62 \\
(1502.71)\end{array}$ & $\begin{array}{c}1101.73 \\
(1718.937)\end{array}$ & $\begin{array}{c}944.41 \\
(1426.11)\end{array}$ & $\begin{array}{c}1315.37 * * * \\
(2033.33)\end{array}$ \\
\hline Number of observations & 482 & 922 & 531 & 391 \\
\hline
\end{tabular}

Notes: Mean values for the pooled sample, including the 2012 and 2015 survey rounds, are shown with standard deviations in parentheses. *** mean values between columns (1) and (2) and between columns (3) and (4) are significantly different at the $1 \%$ level.

\subsubsection{Associations between oil palm cultivation and nutrition}

We now use the regression models described above to analyze associations between oil palm cultivation and nutrition while controlling for potentially confounding factors. Table 4 shows estimates of the model in equation (1), with the nutrition indicators as dependent variables and the two oil palm dummies (oil palm only, oil palm plus rubber) as the main explanatory variables. We estimate separate models for the different nutrition indicators. For the model with the dietary diversity score (DDS) as the dependent variable, we use a linear specification. ${ }^{5}$ For the calorie and micronutrient models, we use a log-transformation of the dependent variables to achieve a more symmetric distribution and a better model fit.

In the models shown in Table 4, oil palm cultivation is positively and significantly associated with better nutrition and dietary quality, also after controlling for other relevant factors. Households that only cultivate oil palm consume 0.36 more food groups than households that only cultivate rubber (reference group). Similarly, the consumption of calories is around $10 \%$ higher, and the consumption of vitamin A, zinc, and iron is $32 \%, 12 \%$, and $19 \%$ higher, respectively, in oil palm cultivating households. ${ }^{6}$

\footnotetext{
${ }^{5} \mathrm{We}$ also tried a Poisson specification to better account for the fact that DDS is a count variable. The results were similar. However, the data do not satisfy the equi-dispersion assumption of the Poisson model.

${ }^{6}$ The percentage effect of dummy variables in log-linear models is calculated as $\left(e^{\text {coefficient }}-1\right) \times 100$.
} 
Table 4 Associations between oil palm cultivation and nutrition

\begin{tabular}{|c|c|c|c|c|c|}
\hline & DDS & Calories (log) & Vit. A (log) & Zinc $(\log )$ & Iron $(\log )$ \\
\hline Oil palm only (dummy) & $\begin{array}{c}0.357 * * * \\
(0.108)\end{array}$ & $\begin{array}{l}0.094 * * * \\
(0.030)\end{array}$ & $\begin{array}{l}0.278 * * * \\
(0.102)\end{array}$ & $\begin{array}{l}0.111 * * * \\
(0.028)\end{array}$ & $\begin{array}{c}0.173 * * * \\
(0.049)\end{array}$ \\
\hline $\begin{array}{l}\text { Oil palm plus rubber } \\
\text { (dummy) }\end{array}$ & $\begin{array}{c}0.305 * * * \\
(0.093)\end{array}$ & $\begin{array}{l}0.130 * * * \\
(0.033)\end{array}$ & $\begin{array}{l}0.251 * * * \\
(0.062)\end{array}$ & $\begin{array}{c}0.135 * * * \\
(0.032)\end{array}$ & $\begin{array}{c}0.181 * * * \\
(0.036)\end{array}$ \\
\hline Total land size (ha) & $\begin{array}{c}0.007 \\
(0.004)\end{array}$ & $\begin{array}{l}0.008 * * * \\
(0.003)\end{array}$ & $\begin{array}{l}0.013 * * * \\
(0.005)\end{array}$ & $\begin{array}{c}0.007 * * * \\
(0.003)\end{array}$ & $\begin{array}{c}0.008 * * \\
(0.003)\end{array}$ \\
\hline $\begin{array}{l}\text { Female-headed household } \\
\text { (dummy) }\end{array}$ & $\begin{array}{l}-0.316^{*} \\
(0.168)\end{array}$ & $\begin{array}{c}0.017 \\
(0.065)\end{array}$ & $\begin{array}{l}-0.208 \\
(0.158)\end{array}$ & $\begin{array}{l}-0.012 \\
(0.063)\end{array}$ & $\begin{array}{c}0.026 \\
(0.085)\end{array}$ \\
\hline $\begin{array}{l}\text { Number of adult women in } \\
\text { the household }\end{array}$ & $\begin{array}{c}0.085 \\
(0.052)\end{array}$ & $\begin{array}{c}-0.069 * * * \\
(0.015)\end{array}$ & $\begin{array}{l}-0.056 \\
(0.051)\end{array}$ & $\begin{array}{c}-0.054 * * * \\
(0.017)\end{array}$ & $\begin{array}{c}-0.085 * * * \\
(0.025)\end{array}$ \\
\hline $\begin{array}{l}\text { Number of adult men in the } \\
\text { household }\end{array}$ & $\begin{array}{c}0.047 \\
(0.039)\end{array}$ & $\begin{array}{c}-0.046 * * * \\
(0.017)\end{array}$ & $\begin{array}{l}-0.052 \\
(0.035)\end{array}$ & $\begin{array}{c}-0.044 * * * \\
(0.015)\end{array}$ & $\begin{array}{l}-0.014 \\
(0.022)\end{array}$ \\
\hline $\begin{array}{l}\text { Number of children in the } \\
\text { household }\end{array}$ & $\begin{array}{c}0.022 \\
(0.041)\end{array}$ & $\begin{array}{c}-0.072 * * * \\
(0.011)\end{array}$ & $\begin{array}{c}-0.080 * * \\
(0.035)\end{array}$ & $\begin{array}{c}-0.051 * * * \\
(0.011)\end{array}$ & $\begin{array}{c}-0.069 * * * \\
(0.019)\end{array}$ \\
\hline $\begin{array}{l}\text { Mean education of adult } \\
\text { women (years) }\end{array}$ & $\begin{array}{l}0.044 * * * \\
(0.014)\end{array}$ & $\begin{array}{l}0.014 * * * \\
(0.004)\end{array}$ & $\begin{array}{l}0.040 * * * \\
(0.011)\end{array}$ & $\begin{array}{c}0.011 * * \\
(0.005)\end{array}$ & $\begin{array}{c}0.020 * * * \\
(0.005)\end{array}$ \\
\hline $\begin{array}{l}\text { Mean education of adult } \\
\text { men (years) }\end{array}$ & $\begin{array}{c}0.038 * * * \\
(0.013)\end{array}$ & $\begin{array}{c}0.005 \\
(0.004)\end{array}$ & $\begin{array}{l}0.035 * * * \\
(0.012)\end{array}$ & $\begin{array}{c}0.001 \\
(0.005)\end{array}$ & $\begin{array}{l}0.010 * \\
(0.006)\end{array}$ \\
\hline Mean age of adult women & $\begin{array}{l}-0.005 \\
(0.004)\end{array}$ & $\begin{array}{c}0.001 \\
(0.001)\end{array}$ & $\begin{array}{l}-2.45 \mathrm{e}-1 \\
(0.003)\end{array}$ & $\begin{array}{l}3.41 \mathrm{e}-1 \\
(0.002)\end{array}$ & $\begin{array}{l}-0.001 \\
(0.002)\end{array}$ \\
\hline Mean age of adult men & $\begin{array}{l}-0.001 \\
(0.005)\end{array}$ & $\begin{array}{l}0.002^{*} \\
(0.001)\end{array}$ & $\begin{array}{c}0.005 \\
(0.004)\end{array}$ & $\begin{array}{l}-8.71 \mathrm{e}-6 \\
(0.001)\end{array}$ & $\begin{array}{c}0.003 \\
(0.002)\end{array}$ \\
\hline $\begin{array}{l}\text { Access to formal credit } \\
\text { (dummy) }\end{array}$ & $\begin{array}{l}-0.04 \\
(0.08)\end{array}$ & $\begin{array}{l}0.044^{*} \\
(0.025)\end{array}$ & $\begin{array}{c}0.008 \\
(0.056)\end{array}$ & $\begin{array}{c}0.043 \\
(0.028)\end{array}$ & $\begin{array}{c}0.034 \\
(0.038)\end{array}$ \\
\hline Melayu (dummy) & $\begin{array}{c}-0.271 * * * \\
(0.072)\end{array}$ & $\begin{array}{l}-0.027 \\
(0.023)\end{array}$ & $\begin{array}{l}-0.118^{*} \\
(0.063)\end{array}$ & $\begin{array}{c}-0.071 * * * \\
(0.023)\end{array}$ & $\begin{array}{c}-0.117 * * * \\
(0.038)\end{array}$ \\
\hline $\begin{array}{l}\text { Non-random village } \\
\text { (dummy) }\end{array}$ & $\begin{array}{c}0.375 * * * \\
(0.128)\end{array}$ & $\begin{array}{l}0.081 * * \\
(0.034)\end{array}$ & $\begin{array}{c}0.199 * * * \\
(0.076)\end{array}$ & $\begin{array}{c}0.071 * * * \\
(0.021)\end{array}$ & $\begin{array}{c}0.067 \\
(0.049)\end{array}$ \\
\hline Distance to market $(\mathrm{km})$ & $\begin{array}{c}0.004 \\
(0.006)\end{array}$ & $\begin{array}{l}2.79 \mathrm{e}-1 \\
(0.001)\end{array}$ & $\begin{array}{l}0.008^{*} \\
(0.004)\end{array}$ & $\begin{array}{l}-0.001 \\
(0.002)\end{array}$ & $\begin{array}{c}0.003 \\
(0.003)\end{array}$ \\
\hline $\begin{array}{l}\text { Survey round } 2015 \\
\text { (dummy) }\end{array}$ & $\begin{array}{c}0.033 \\
(0.064)\end{array}$ & $\begin{array}{c}-0.101 * * * \\
(0.027)\end{array}$ & $\begin{array}{c}-0.159 * * * \\
(0.051)\end{array}$ & $\begin{array}{l}-0.059 * \\
(0.032)\end{array}$ & $\begin{array}{c}-0.138 * * * \\
(0.034)\end{array}$ \\
\hline Constant & $\begin{array}{c}6.015 * * * \\
(0.305)\end{array}$ & $\begin{array}{l}7.872 * * * \\
(0.066)\end{array}$ & $\begin{array}{l}5.779 * * * \\
(0.231)\end{array}$ & $\begin{array}{c}2.354 * * * \\
(0.070)\end{array}$ & $\begin{array}{c}2.666^{* * * *} \\
(0.109)\end{array}$ \\
\hline R-squared & 0.105 & 0.177 & 0.107 & 0.129 & 0.129 \\
\hline Chi2 & 256.526 & 273.906 & 269.644 & 295.427 & 244.226 \\
\hline Number of observations & 1362 & 1362 & 1362 & 1362 & 1362 \\
\hline
\end{tabular}

Notes: Coefficient estimates of random effects panel models are shown with standard errors in parentheses. * significant at $10 \%$ level; $* *$ significant at $5 \%$ level; *** significant at $1 \%$ level.

As a robustness check, we ran the same models as cross-section specifications using 2015 values for the outcome variables and 2012 values for the explanatory variables to reduce possible issues of reverse causality. Also in these alternative specifications, oil palm cultivation has positive and significant coefficients in all models (Table A.2 in the Appendix). These results support our first and overarching hypothesis that oil palm cultivation is positively associated with household nutrition and dietary quality.

In terms of the control variables in Table 4, total land size and education are positively associated with nutrition, as one would expect. Interesting to see is that women's education has 
a larger positive association with dietary quality than men's education, which underlines the vital role of women for family nutrition and health. The autochthonous Melayu population has lower dietary quality than the immigrants from Java that make up the largest share of the reference group. This may be related to differences in culture and dietary habits. However, the dietary differences between the ethnicities are probably also a reflection of differences in lifestyle and socioeconomic status. Javanese households have higher average incomes; many of them were supported through the government's transmigration program, as discussed above. ${ }^{7}$ Finally, the dummy for the 2015 survey round has significantly negative coefficients in most of the models in Table 4, implying that the dietary situation was worse in 2015 than in 2012. This reflects the stark decline of international prices for rubber and palm oil between 2012 and 2015, leading to lower incomes for producers of these crops (Kubitza et al., 2018a).

\subsubsection{Testing the income mechanism}

We hypothesized that at least some of the positive association between oil palm cultivation and nutrition is channeled through the income mechanism. The descriptive comparisons in Table 1 suggested that oil palm cultivation contributes to higher household expenditures, our proxy of household income, or living standard. Positive living standard effects of oil palm cultivation in Jambi were also shown more formally by Euler at al. (2017) and Kubitza et al. (2018a). What has not been shown so far is that higher household expenditures are indeed associated with better diets and nutrition in the local context. This is confirmed in Table 5 with the nutrition indicators as dependent and household expenditures as explanatory variables.

We express household expenditures in log-terms so we have double-log specifications for the calorie and micronutrient models. The results in Table 5 suggest that a $1 \%$ increase in household expenditures is associated with a $0.45 \%$ increase in calorie consumption, a $0.73 \%$ increase in vitamin A consumption, a $0.45 \%$ increase in zinc consumption, and a $0.57 \%$ increase in iron consumption. Positive and significant expenditure elasticities of calorie and nutrient consumption are also found in alternative cross-section specifications with 2015 values for the outcome variables and 2012 values for the explanatory variables (Table A.4 in the Appendix).

\footnotetext{
${ }^{7}$ We also ran alternative regressions, using a dummy variable for transmigrant villages instead of the Melayu dummy and an additional oil palm-transmigrant interaction term. These alternative specifications are shown in Table A.3 in the Appendix. Oil palm cultivation remains positive and significant in all models. Likewise, the transmigrant village dummy is significantly positive in most of the models, whereas the interaction term is not significant in any of the models. These additional results suggest that the association between oil palm cultivation and nutrition as such is not affected by transmigration status or ethnicity.
} 
Table 5 Association between household expenditures and nutrition

\begin{tabular}{|c|c|c|c|c|c|}
\hline & DDS & Calorie $(\log )$ & Vit. A $(\log )$ & Zinc $(\log )$ & Iron $(\log )$ \\
\hline \multirow[t]{2}{*}{ Expenditures (log, IDR) } & $0.748 * * *$ & $0.453 * * *$ & $0.733 * * *$ & $0.453 * * *$ & $0.571 * * *$ \\
\hline & $(0.067)$ & $(0.021)$ & $(0.065)$ & $(0.021)$ & $(0.027)$ \\
\hline \multirow[t]{2}{*}{ Total land size (ha) } & $-0.007 * * *$ & -0.001 & -0.001 & -0.001 & $-0.003 * *$ \\
\hline & $(0.003)$ & $(0.001)$ & $(0.002)$ & $(0.001)$ & $(0.001)$ \\
\hline \multirow{2}{*}{$\begin{array}{l}\text { Female-headed household } \\
\text { (dummy) }\end{array}$} & -0.250 & $0.080 *$ & -0.130 & 0.048 & 0.105 \\
\hline & $(0.163)$ & $(0.041)$ & $(0.134)$ & $(0.039)$ & $(0.066)$ \\
\hline \multirow{2}{*}{$\begin{array}{l}\text { Number of adult women in } \\
\text { the household }\end{array}$} & $0.142 * * *$ & $-0.032 * *$ & -0.005 & -0.016 & $-0.041 * *$ \\
\hline & $(0.049)$ & $(0.012)$ & $(0.044)$ & $(0.015)$ & $(0.020)$ \\
\hline \multirow{2}{*}{$\begin{array}{l}\text { Number of adult men in the } \\
\text { household }\end{array}$} & $0.097 * *$ & -0.019 & -0.005 & -0.015 & $0.028 *$ \\
\hline & $(0.041)$ & $(0.013)$ & $(0.032)$ & $(0.012)$ & $(0.017)$ \\
\hline \multirow{2}{*}{$\begin{array}{l}\text { Number of children in the } \\
\text { household }\end{array}$} & $0.102 * *$ & $-0.023 * * *$ & -0.002 & -0.001 & -0.007 \\
\hline & $(0.041)$ & $(0.008)$ & $(0.036)$ & $(0.008)$ & $(0.015)$ \\
\hline \multirow{2}{*}{$\begin{array}{l}\text { Mean education of adult } \\
\text { women (years) }\end{array}$} & $0.022 *$ & 0.001 & 0.018 & -0.002 & 0.004 \\
\hline & $(0.013)$ & $(0.003)$ & $(0.011)$ & $(0.004)$ & $(0.005)$ \\
\hline \multirow{2}{*}{$\begin{array}{l}\text { Mean education of adult } \\
\text { men (year) }\end{array}$} & $0.028 * *$ & -0.002 & $0.024 * *$ & -0.006 & 0.002 \\
\hline & $(0.013)$ & $(0.003)$ & $(0.011)$ & $(0.004)$ & $(0.005)$ \\
\hline \multirow[t]{2}{*}{ Mean age of adult women } & $-0.007 *$ & $4.216 \mathrm{e}-4$ & -0.002 & $-4.358 \mathrm{e}-4$ & -0.002 \\
\hline & $(0.004)$ & $(0.001)$ & $(0.003)$ & $(0.001)$ & $(0.002)$ \\
\hline \multirow[t]{2}{*}{ Mean age of adult men } & -0.001 & $0.002 *$ & 0.005 & $4.97 \mathrm{e}-5$ & 0.003 \\
\hline & $(0.005)$ & $(0.001)$ & $(0.003)$ & $(0.001)$ & $(0.002)$ \\
\hline \multirow{4}{*}{$\begin{array}{l}\text { Female off-farm } \\
\text { employment (dummy) } \\
\text { Male off-farm employment } \\
\text { (dummy) }\end{array}$} & $0.144 * *$ & $0.039 *$ & $0.150 * *$ & 0.024 & $0.057 * *$ \\
\hline & $(0.066)$ & $(0.023)$ & $(0.061)$ & $(0.021)$ & $(0.028)$ \\
\hline & -0.070 & -0.021 & -0.049 & -0.027 & $-0.072 * *$ \\
\hline & $(0.068)$ & $(0.021)$ & $(0.060)$ & $(0.024)$ & $(0.032)$ \\
\hline \multirow{2}{*}{$\begin{array}{l}\text { Female on-farm work } \\
\text { (hours/year) }\end{array}$} & $-6.51 e-5$ & $-1.33 e-5$ & $-9.61 e-5 * *$ & $-5.16 \mathrm{e}-06$ & $-8.55 e-06$ \\
\hline & $(5.94 \mathrm{e}-5)$ & $(1.77 e-5)$ & $(4.59 \mathrm{e}-5)$ & $(1.86 e-5)$ & $(2.32 \mathrm{e}-5)$ \\
\hline \multirow{2}{*}{$\begin{array}{l}\text { Male on-farm work } \\
\text { (hours/year) }\end{array}$} & $-9.10 e-06$ & $1.28 \mathrm{e}-5$ & $4.66 \mathrm{e}-06$ & $5.54 \mathrm{e}-06$ & $-2.65 e-06$ \\
\hline & $(3.6 e-5)$ & $(9.16 e-6)$ & $(3.3 e-5)$ & $(1.09 \mathrm{e}-5)$ & $(1.28 \mathrm{e}-5)$ \\
\hline \multirow{2}{*}{$\begin{array}{l}\text { Access to formal credit } \\
\text { (dummy) }\end{array}$} & -0.061 & 0.014 & -0.028 & 0.017 & 0.007 \\
\hline & $(0.080)$ & $(0.022)$ & $(0.056)$ & $(0.024)$ & $(0.032)$ \\
\hline \multirow[t]{2}{*}{ Melayu (dummy) } & $-0.249 * * *$ & -0.002 & $-0.091 *$ & $-0.048 * * *$ & $-0.092 * * *$ \\
\hline & $(0.063)$ & $(0.016)$ & $(0.053)$ & $(0.018)$ & $(0.031)$ \\
\hline \multirow{2}{*}{$\begin{array}{l}\text { Non-random village } \\
\text { (dummy) }\end{array}$} & $0.316^{* *}$ & 0.042 & $0.136^{*}$ & $0.035 * *$ & 0.023 \\
\hline & $(0.124)$ & $(0.027)$ & $(0.072)$ & $(0.016)$ & $(0.045)$ \\
\hline \multirow[t]{2}{*}{ Distance to market $(\mathrm{km})$} & 0.006 & 0.002 & $0.010 * *$ & 0.001 & $0.005^{* *}$ \\
\hline & $(0.006)$ & $(0.001)$ & $(0.004)$ & $(0.002)$ & $(0.003)$ \\
\hline \multirow{2}{*}{$\begin{array}{l}\text { Survey round } 2015 \\
\text { (dummy) }\end{array}$} & $0.121 * *$ & $-0.046 * *$ & -0.070 & -0.004 & $-0.066 * *$ \\
\hline & $(0.059)$ & $(0.019)$ & $(0.050)$ & $(0.025)$ & $(0.029)$ \\
\hline \multirow[t]{2}{*}{ Constant } & $4.359 * * *$ & $6.804 * * *$ & $4.132 * * *$ & $1.293 * * *$ & $1.372 * * *$ \\
\hline & $(0.394)$ & $(0.090)$ & $(0.296)$ & $(0.096)$ & $(0.141)$ \\
\hline R-squared & 0.184 & 0.454 & 0.221 & 0.376 & 0.338 \\
\hline Chi2 & 432.632 & 1877.656 & 950.956 & 1579.276 & 1682.851 \\
\hline Number of observations & 1362 & 1362 & 1362 & 1362 & 1362 \\
\hline
\end{tabular}

Notes: Coefficient estimates of random effects panel models are shown with standard errors in parentheses. * significant at $10 \%$ level; ** significant at $5 \%$ level; *** significant at $1 \%$ level.

\subsubsection{Testing the gender mechanism}

We now test whether oil palm cultivation is associated with nutrition also through the mechanism of changing gender roles, especially through more off-farm employment. In the first step, we test whether oil palm cultivation is associated with a lower amount of female and male household labor used in on-farm activities. As female and male labor hours are not independent 
within a farm household, we use a seemingly unrelated regression (SUR) framework. Results are shown in columns (1) and (2) of Table 6. Adding oil palm to rubber such that both crops are cultivated on the farm does not seem to influence household labor use, which is plausible because the rubber still has to be harvested regularly. However, households cultivating oil palm as the only crop use significantly less household labor (406 fewer female hours and 768 fewer male hours per year).

Associations between oil palm cultivation and off-farm employment of female and male household members are shown in columns (3) and (4) of Table 6. For male household members, the probability of off-farm employment is 65 percentage points higher when the household cultivates oil palm instead of rubber. This is very plausible given the lower on-farm family labor requirements in oil palm. Strikingly, however, for female household members, the likelihood of off-farm employment is not significantly associated with oil palm cultivation, despite the lower on-farm requirements for female labor. As mentioned, this may be due to human capital and cultural restrictions for women to pursue off-farm work. Another reason could be the positive income effect of oil palm cultivation: with a sufficient family income, women may not have to pursue off-farm work, which often involves low-paid activities in the local setting. In any case, the hypothesis that oil palm cultivation is associated with more female off-farm employment has to be rejected. ${ }^{8}$

Interesting additional insights on what contributes to more female off-farm employment can be gained when taking a closer look at the control variables in column (3) of Table 6. The likelihood of female off-farm employment is positively associated with the number of adult women living in the household and their mean education level, which is plausible. Better education improves the access to more lucrative off-farm jobs. Interestingly, the likelihood of female off-farm employment is also higher with the mean education level of male adults in the household. A possible explanation is that better-educated men are less restricted by cultural norms and more supportive of developments towards gender equity.

Oil palm-cultivating households do not have a higher likelihood of female off-farm employment in general. Nevertheless, it is interesting to test whether female off-farm work as such has any association with household nutrition and diets. The results in Table A.6 in the Appendix confirm

\footnotetext{
${ }^{8}$ In cross-section models with 2015 values for the dependent variables and 2012 values for the explanatory variables we actually find a significantly positive association between oil palm cultivation and female off-farm employment (Table A.5 in the Appendix). As mentioned, rubber and palm oil prices were low in 2015 . The results suggest that female labor market responses to such price shocks may possibly be easier in households that only cultivate oil palm, due to the lower on-farm female labor requirements.
} 
that it has. Female off-farm employment is positively and significantly associated with nutrition and dietary quality. One could argue that this is just an income effect because female off-farm employment is associated with higher household incomes. However, as the results in Table 5 show, the association between female off-farm employment and nutrition remains positive and significant also after controlling for total household expenditures. Moreover, unlike female offfarm employment, male off-farm employment is not positively associated with nutrition, neither with nor without controlling for total household expenditures (Tables 5 and A6).

Table 6 Associations between oil palm cultivation and household labor allocation by gender

\begin{tabular}{|c|c|c|c|c|}
\hline & \multicolumn{2}{|c|}{ On-farm work (hours/year) } & \multicolumn{2}{|c|}{ Off-farm employment (dummy) } \\
\hline & $\begin{array}{c}(1) \\
\text { Female labor } \\
\end{array}$ & $\begin{array}{c}(2) \\
\text { Male labor } \\
\end{array}$ & $\begin{array}{c}(3) \\
\text { Female employment } \\
\end{array}$ & $\begin{array}{c}(4) \\
\text { Male employment } \\
\end{array}$ \\
\hline Oil palm only (dummy) & $\begin{array}{c}-405.839 * * * \\
(39.949)\end{array}$ & $\begin{array}{c}-768.086 * * * \\
(67.384)\end{array}$ & $\begin{array}{c}0.145 \\
(0.236)\end{array}$ & $\begin{array}{c}0.650 * * * \\
(0.248)\end{array}$ \\
\hline $\begin{array}{l}\text { Oil palm plus rubber } \\
\text { (dummy) }\end{array}$ & $\begin{array}{l}-29.911 \\
(34.309)\end{array}$ & $\begin{array}{c}44.467 \\
(57.286)\end{array}$ & $\begin{array}{l}-0.049 \\
(0.204)\end{array}$ & $\begin{array}{c}0.083 \\
(0.201)\end{array}$ \\
\hline Total land size (ha) & $\begin{array}{l}-2.455 \\
(1.789)\end{array}$ & $\begin{array}{c}3.684 \\
(3.003)\end{array}$ & $\begin{array}{l}-0.013 \\
(0.012)\end{array}$ & $\begin{array}{l}-0.005 \\
(0.011)\end{array}$ \\
\hline $\begin{array}{l}\text { Female-headed household } \\
\text { (dummy) }\end{array}$ & $\begin{array}{l}-40.183 \\
(71.997)\end{array}$ & $\begin{array}{c}-52.084 \\
(118.632)\end{array}$ & $\begin{array}{l}0.658 * \\
(0.389)\end{array}$ & $\begin{array}{c}0.322 \\
(0.408)\end{array}$ \\
\hline $\begin{array}{l}\text { Number of adult women } \\
\text { in the household }\end{array}$ & $\begin{array}{l}51.128 * * \\
(22.286)\end{array}$ & $\begin{array}{c}56.986 \\
(36.713)\end{array}$ & $\begin{array}{l}0.490 * * * \\
(0.127)\end{array}$ & $\begin{array}{c}0.103 \\
(0.128)\end{array}$ \\
\hline $\begin{array}{l}\text { Number of adult men in } \\
\text { the household }\end{array}$ & $\begin{array}{c}12.033 \\
(19.224)\end{array}$ & $\begin{array}{c}190.364 * * * \\
(31.673)\end{array}$ & $\begin{array}{c}0.096 \\
(0.113)\end{array}$ & $\begin{array}{c}0.490 * * * \\
(0.121)\end{array}$ \\
\hline $\begin{array}{l}\text { Number of children in the } \\
\text { household }\end{array}$ & $\begin{array}{l}18.956 \\
(13.983)\end{array}$ & $\begin{array}{l}-3.412 \\
(23.281)\end{array}$ & $\begin{array}{c}0.111 \\
(0.084)\end{array}$ & $\begin{array}{c}0.075 \\
(0.085)\end{array}$ \\
\hline $\begin{array}{l}\text { Mean education of adult } \\
\text { women (years) }\end{array}$ & $\begin{array}{l}-1.820 \\
(5.158)\end{array}$ & $\begin{array}{l}28.170 * * * \\
(8.546)\end{array}$ & $\begin{array}{c}0.065 * * \\
(0.031)\end{array}$ & $\begin{array}{c}0.024 \\
(0.031)\end{array}$ \\
\hline $\begin{array}{l}\text { Mean education of adult } \\
\text { men (years) }\end{array}$ & $\begin{array}{c}1.267 \\
(5.078)\end{array}$ & $\begin{array}{c}-16.501 * \\
(8.430)\end{array}$ & $\begin{array}{l}0.057 * \\
(0.031)\end{array}$ & $\begin{array}{l}0.055^{*} \\
(0.030)\end{array}$ \\
\hline Mean age of adult women & $\begin{array}{l}6.606 * * * \\
(1.680)\end{array}$ & $\begin{array}{l}11.385 * * * \\
(2.761)\end{array}$ & $\begin{array}{l}-0.003 \\
(0.010)\end{array}$ & $\begin{array}{c}-0.032 * * * \\
(0.010)\end{array}$ \\
\hline Mean age of adult men & $\begin{array}{c}0.385 \\
(1.550)\end{array}$ & $\begin{array}{l}5.366 * * \\
(2.553)\end{array}$ & $\begin{array}{l}-0.001 \\
(0.010)\end{array}$ & $\begin{array}{c}-0.027 * * * \\
(0.010)\end{array}$ \\
\hline $\begin{array}{l}\text { Access to formal credit } \\
\text { (dummy) }\end{array}$ & $\begin{array}{l}84.651 * * * \\
(30.328)\end{array}$ & $\begin{array}{c}47.819 \\
(49.865)\end{array}$ & $\begin{array}{c}0.185 \\
(0.169)\end{array}$ & $\begin{array}{l}0.305^{*} \\
(0.172)\end{array}$ \\
\hline Melayu (dummy) & $\begin{array}{l}-40.319 \\
(28.100)\end{array}$ & $\begin{array}{c}-193.650 * * * \\
(47.677)\end{array}$ & $\begin{array}{l}-0.128 \\
(0.166)\end{array}$ & $\begin{array}{c}0.196 \\
(0.164)\end{array}$ \\
\hline $\begin{array}{l}\text { Non-random village } \\
\text { (dummy) }\end{array}$ & $\begin{array}{c}38.152 \\
(40.541)\end{array}$ & $\begin{array}{c}300.675^{* * *} \\
(69.577)\end{array}$ & $\begin{array}{l}0.418^{*} \\
(0.233)\end{array}$ & $\begin{array}{c}0.298 \\
(0.240)\end{array}$ \\
\hline Distance to market $(\mathrm{km})$ & $\begin{array}{l}-0.080 \\
(1.975)\end{array}$ & $\begin{array}{c}1.557 \\
(3.299)\end{array}$ & $\begin{array}{c}-1.174 \mathrm{e}-4 \\
(0.012)\end{array}$ & $\begin{array}{c}0.005 \\
(0.011)\end{array}$ \\
\hline $\begin{array}{l}\text { Survey round } 2015 \\
\text { (dummy) }\end{array}$ & $\begin{array}{c}127.893 * * * \\
(25.990)\end{array}$ & $\begin{array}{c}-80.317 * * \\
(40.621)\end{array}$ & $\begin{array}{c}0.573 * * * \\
(0.143)\end{array}$ & $\begin{array}{c}0.713 * * * \\
(0.141)\end{array}$ \\
\hline Number of observations & 1362 & 1362 & 1362 & 1362 \\
\hline
\end{tabular}

Notes: Coefficient estimates of random effects panel models are shown with standard errors in parentheses. The models in columns (1) and (2) were estimated with a SUR estimator. The models in columns (3) and (4) were estimated with a logit estimator; coefficients can be interpreted as marginal effects. * significant at $10 \%$ level; ** significant at $5 \%$ level; *** significant at $1 \%$ level. 


\subsection{Conclusion}

The massive expansion of oil palm in many tropical regions is damaging for the environment and is often also perceived as unfavorable for food security and nutrition. However, relationships between oil palm expansion and nutrition have hardly been analyzed up till now. In this study, we used panel data from smallholder farm households in Indonesia to address this research gap. The results suggest that oil palm cultivation is positively and significantly associated with nutrition and dietary quality, also after controlling for possible confounding factors.

We also analyzed the underlying mechanisms. Food crop production in the study area is very limited regardless of whether or not the farms are involved in oil palm cultivation. Farm households obtain almost all of their food from the market; subsistence does not play a significant role in this context. The association between oil palm cultivation and nutrition is primarily channeled through household income gains. Oil palm is more profitable than the cultivation of alternative crops, and the additional income improves households' economic access to nutritious foods from the market.

Another mechanism that we analyzed is a potential change in intra-household gender roles through oil palm cultivation. Oil palm is less labor-intensive than alternative crops so that less household labor is required for on-farm work. The household labor saved could be used for more off-farm economic activities and additional income generation. Off-farm employment of female household members could increase female financial autonomy, which might have positive effects on household nutrition. Our results show that oil palm cultivation is associated with lower on-farm labor time of both male and female household members. However, a positive association between oil palm cultivation and off-farm employment was only found for male and not for female members. Despite the female labor savings on the farm, there seem to be human capital and cultural constraints that prevent women from participating in more lucrative off-farm employment. A certain fraction of the women works in off-farm activities, and our estimates demonstrate that female off-farm employment is indeed positively associated with family nutrition, even after controlling for total household income. However, this seems to be unrelated to oil palm cultivation. Factors that are positively associated with female offfarm employment are female and male education, among others.

We conclude that oil palm cultivation is positively associated with food security and nutrition and that this association is primarily channeled through positive income effects. This does not 
mean that further oil palm expansion is desirable, because the environmental costs must not be ignored. Furthermore, not all households are able to cultivate oil palm due to capital constraints, which may lead to rising economic inequality over time. However, many smallholder farmers benefit economically and nutritionally, a finding that needs to be kept in mind when designing policies for more sustainable land use.

In closing, two limitations of this research should be mentioned. First, the results are specific to the study region in Indonesia. Land-use change towards oil palm and other cash crops may have less favorable effects on diets and nutrition in locations where food markets are not well developed, and subsistence still plays a more crucial role. Second, the estimates should be interpreted as associations and not as causal effects. Even though we used panel data and carried out robustness checks to deal with possible concerns about reverse causality, endogeneity issues cannot be ruled out completely. The fact that the empirical results are plausible also from a theory perspective is re-assuring. Nevertheless, further research with longer-term data from various geographical contexts is needed to further enhance our understanding of the multifaceted linkages between land-use change, nutrition, and gender roles. 


\title{
3. Oil Palm and Structural Transformation of Agriculture in Indonesia9
}

\begin{abstract}
Structural transformation of agriculture typically involves a gradual increase of mean farm sizes and a reallocation of labor from agriculture to other sectors. Such structural transformation is often fostered through innovations in agriculture and newly emerging opportunities in manufacturing and services. Here, we use panel data from farm households in Indonesia to test and support the hypothesis that the recent oil palm boom contributes to structural transformation. Oil palm is capital-intensive but requires much less labor per hectare than traditional crops. Farmers who adopted oil palm increase their cropping area, meaning that some of the labor saved per hectare is used for expanding the farm. Average farm sizes increased in recent years. In addition, we observe a positive association between oil palm adoption and off-farm income, suggesting that some of the labor saved per hectare is also reallocated to non-agricultural activities. Oil palm adoption significantly increases the likelihood of households pursuing own non-farm businesses. However, oil palm adoption does not increase the likelihood of being employed in manufacturing or services, which is probably due to the limited non-farm labor demand in the local setting. Equitable and sustainable agricultural transformation requires new lucrative non-agricultural employment opportunities in rural areas.
\end{abstract}

Keywords: Oil palm; Structural transformation; Farm size; Off-farm employment; Rural development

\footnotetext{
${ }^{9}$ This essay is forthcoming in Agricultural Economics and co-authored by Daniel Chrisendo, the lead author, Hermanto Siregar (HS), and Matin Qaim (MQ). DC developed the research idea, conducted the survey, curated the data, implemented the econometric modelling, conducted the analyses, wrote the first draft of the essay, and revised the essay. HR revised the essay. MQ developed the research idea, revised the essay, and supervised.
}

Acknowledgement: The authors thank the editor and two anonymous reviewers for helpful comments and suggestions to improve this paper. 


\subsection{Introduction}

The structural transformation of agriculture, or of economies more broadly, typically involves productivity growth in farming, an increase in mean farm sizes, and a gradual shift of agricultural labor to other sectors, including manufacturing and services (Bokusheva \& Kimura, 2016; Jayne et al., 2016). During this structural transformation process, the share of labor working in agriculture and agriculture's relative contribution to the total economy decline, whereas the shares of the manufacturing and service industries increase (Duarte \& Restuccia, 2010; Herrendorf et al., 2014). Productivity-enhancing and labor-saving innovations in agriculture are often important factors contributing to structural transformation (Pingali, 2007; Alvarez-Cuadrado \& Poschke, 2011; Bustos et al., 2016). Labor that is saved in agriculture is reallocated to jobs in other sectors, which are often more productive (Berger \& Frey, 2016).

All countries with significant economic growth over longer periods of time have seen such a structural transformation (Berger \& Frey, 2016; Bokusheva \& Kimura, 2016). This is also true in Indonesia, where agriculture's contribution to total gross domestic product (GDP) declined from $24 \%$ in 1998 to $13 \%$ in 2018, while the share of agricultural employment in total employment decreased from $45 \%$ to $31 \%$ (World Bank, 2020). One of the major agricultural crops in Indonesia is oil palm, which has gained significant importance during the last 20 years (Qaim et al., 2020). In 2018, oil palm was cultivated in Indonesia on more than 14 million hectares of land, even exceeding the area grown with rice, the country's main staple food (Indonesian Bureau of Statistics, 2019). Palm oil production contributes around $2.5 \%$ to Indonesia's total GDP and employs up to 8 million people in farming and processing (ILO, 2019; Ministry of Agriculture Indonesia, 2019a). Indonesia is the world's largest palm oil producer and exporter worldwide (Qaim et al., 2020). Apart from exports, palm oil is also heavily used domestically as cooking oil, biofuel, and as an important ingredient in processed foods, cosmetics, and pharmaceutical products (Corley \& Tinker, 2016). The objective of this article is to analyze whether Indonesia' recent oil palm boom has contributed to structural transformation in local agriculture with rising farm sizes and a growing role of rural off-farm employment.

The massive expansion of oil palm in Indonesia has various types of effects, with both negative and positive sustainability outcomes. As some of the oil palm plantations were established on land previously covered with tropical rainforest, the crop's expansion is associated with deforestation, biodiversity loss, and climate change (Obidzinski et al., 2012, Drescher et al., 2016). Spatial overlaps of land concessions for palm oil companies and local community lands 
have also contributed to social conflicts in some situations (Abram et al., 2017). However, more than $40 \%$ of the total oil palm land in Indonesia is not cultivated by large palm oil companies but by small- and medium-sized family farms (Euler et al., 2016). Several studies show that smallholder farmers benefit from oil palm cultivation in terms of higher household living standards, as oil palm is more profitable than traditional crops such as rice or rubber (Euler et al., 2017; Krishn et al., 2017a; Kubitza et al., 2018a). Oil palm is also a labor-saving innovation in the sense that it requires much less labor per hectare than most traditional crops (Feintrenie et al., 2010; Chrisendo et al., 2020).

The labor-saving nature of oil palm may contribute to increasing farm sizes and a growing role of off-farm employment over time, but such effects on structural change have hardly been analyzed up till now. Based on country-level statistics, agriculture in Indonesia is still dominated by very small farms without a visible trend towards consolidation (Winoto \& Siregar, 2008). However, country-level statistics may mask certain trends that occur in regional oil palm hotspots. Euler et al. (2016) and Krishna et al. (2017a) used cross-sectional survey data from Jambi Province, Sumatra, where the expansion of oil palm was particularly strong during the last 20 years, to show that farms cultivating oil palm are somewhat larger than farms cultivating traditional crops. Yet, with cross-sectional data it is hardly possible to establish whether the adoption of oil palm actually contributed to increasing farm sizes. Chrisendo et al. (2020) also used data from Jambi showing that a switch from traditional crops to oil palm reduces the labor intensity per hectare of land, but the labor reallocation to other economic activities was not analyzed in more detail.

Here, we contribute to the existing literature by using panel data collected in three survey rounds from farm households in Jambi Province to analyze the effects of oil palm adoption on structural transformation. Based on a simple conceptual framework we develop concrete research hypotheses, namely that oil palm cultivation contributes to farm size expansion and increases households' involvement in off-farm employment. These hypotheses are tested empirically with descriptive statistics and econometric models. Panel data models with household fixed effects help to reduce self-selection problems and other issues of endogeneity.

The rest of this article is structured as follows. Section 2 provides some background on oil palm cultivation in Jambi. Section 3 explains the analytical framework, including the research hypotheses and the statistical methods used. The household panel survey and the definition and measurement of key variables are described in section 4. Section 5 presents and discusses the empirical results, while section 6 concludes. 


\subsection{Oil palm cultivation in Jambi}

Oil palm and rubber are nowadays the two main crops cultivated in Jambi Province (Qaim et al., 2020). Rubber has been cultivated since the early-twentieth century, mostly in traditional agroforestry systems and as a complement to rice, the main local food crop. Since the midtwentieth century, traditional agroforestry systems lost in importance and were gradually replaced by rubber monoculture plantations (Feintrenie \& Levang, 2009). The importance of local food crop cultivation declined, because farmers could make higher incomes with growing rubber. Rice and other foods could easily be accessed from the market, largely imported from other regions of Indonesia.

Oil palm was sporadically grown in Jambi since the 1960s, but was promoted more strongly since the 1980s (Gatto et al., 2015). The Indonesian government's transmigration programs played an important role in promoting oil palm cultivation among smallholder farmers. In the transmigration programs of the 1980s and 1990s, households from Java and other densely populated islands were resettled to less-developed islands such as Sumatra, where they were supported in the cultivation of cash crops, especially oil palm (Zen et al., 2006; Feintrenie et al., 2010; Bazzi et al., 2016). The transmigrant households started their farming business with the 2-3 hectares of land allocated to them; initially they were poorer than typical autochthonous households in Jambi that had been involved in commercial rubber cultivation for long (Gatto et al., 2017).

To support the transmigrant families in the cultivation of oil palm, the government initiated the so-called Nucleus Estate and Smallholder (NES) schemes (Larson, 1996). These schemes were linked to large public or private companies that managed their own oil palm plantations and additionally procured produce from contracted smallholders. Under these contracts, the transmigrants received subsidized credits and technical support for plantation establishment. Furthermore, the government supported the development and upgrading of infrastructure in newly-created transmigrant communities. While most of the smallholders in the NES schemes were transmigrants, a few autochthonous farmers also participated (Zen et al., 2006; McCarthy et al., 2012). But in general, autochthonous households in Jambi benefited less from the government support and started to adopt oil palm significantly later than transmigrant households (Euler et al., 2016; Gatto et al., 2017).

From the early-2000s onward, the NES schemes and related contractual arrangements between palm oil companies and smallholder farmers lost in importance. While oil palm adoption rates 
in Jambi continue to rise, most smallholders now establish their plantations independently and supply the palm oil mills without a contractual arrangement (Qaim et al., 2020). Plantation establishment requires capital, so poorer households without access to credit are less able to adopt oil palm and benefit from this profitable crop (Euler et al., 2016; McCarthy et al., 2012; McCarthy \& Zen, 2016). While oil palm has helped to lift many households in rural Jambi out of poverty, it also has the potential to contribute to rising inequality under the given institutional conditions (Obidzinski et al., 2012; Abram et al., 2017; Bou Dib et al., 2018a; Bou Dib et al., 2018b).

Besides capital, access to land is also an important factor for establishing new oil palm plantations. Until recently, most of the new oil palm plantations in Jambi were established on forest land, bush land, or fallow areas, but - with increasing land scarcity - rubber plantations are also increasingly converted to oil palm land. The gradual switch from rubber to oil palm is further fueled by low rubber prices (IMF, 2020). Farmers unable to establish their own oil palm plantations sometimes sell some of their land to other farmers. Krishna et al. (2017b) showed that the frequency of land-market transactions in Jambi has increased recently.

In 2018, of the total 14 million hectares of oil palm in Indonesia, around one million hectares were cultivated in Jambi (Ministry of Agriculture Indonesia, 2019a). Of these one million hectares of oil palm land in Jambi, around $40 \%$ were managed by large companies, whereas the rest was cultivated by small- and medium-sized family farms. According to official statistics, around 285,000 farmers in Jambi cultivate oil palm. In addition, close to 200,000 rural laborers in Jambi are employed in the oil palm subsector (Ministry of Agriculture Indonesia, 2019a). For comparison, rubber was grown on 390,000 hectares in Jambi in 2018, so on a much smaller total area than oil palm. However, unlike oil palm, rubber is mostly grown by family farms with only little involvement of large companies. According to official statistics, there were still around 220,000 farmers in Jambi growing rubber in 2018 (Ministry of Agriculture Indonesia, 2019b). In addition, a large number of rural laborers are employed in rubber, often through sharecropping arrangements (Bou Dib et al., 2018b).

\subsection{Analytical framework}

\subsubsection{Conceptual framework}

We want to analyze whether the adoption of oil palm by family farms contributes to structural transformation of agriculture by looking at relevant mechanisms at the micro level over time. 
In general, farmers will only decide to adopt a new crop if it leads to higher profits than traditional crops. However, besides changes in profit, the adoption of the new crop can also lead to changes in capital requirements, input use, labor use, and agroecological conditions (e.g., water and nutrient cycles) (e.g., Mariyono et al., 2010; Mariyono, 2015; Krishna et al., 2017a; Merten et al., 2020). All these changes can lead to a reallocation of household resources with implications for farming structures and employment (Figure 4).

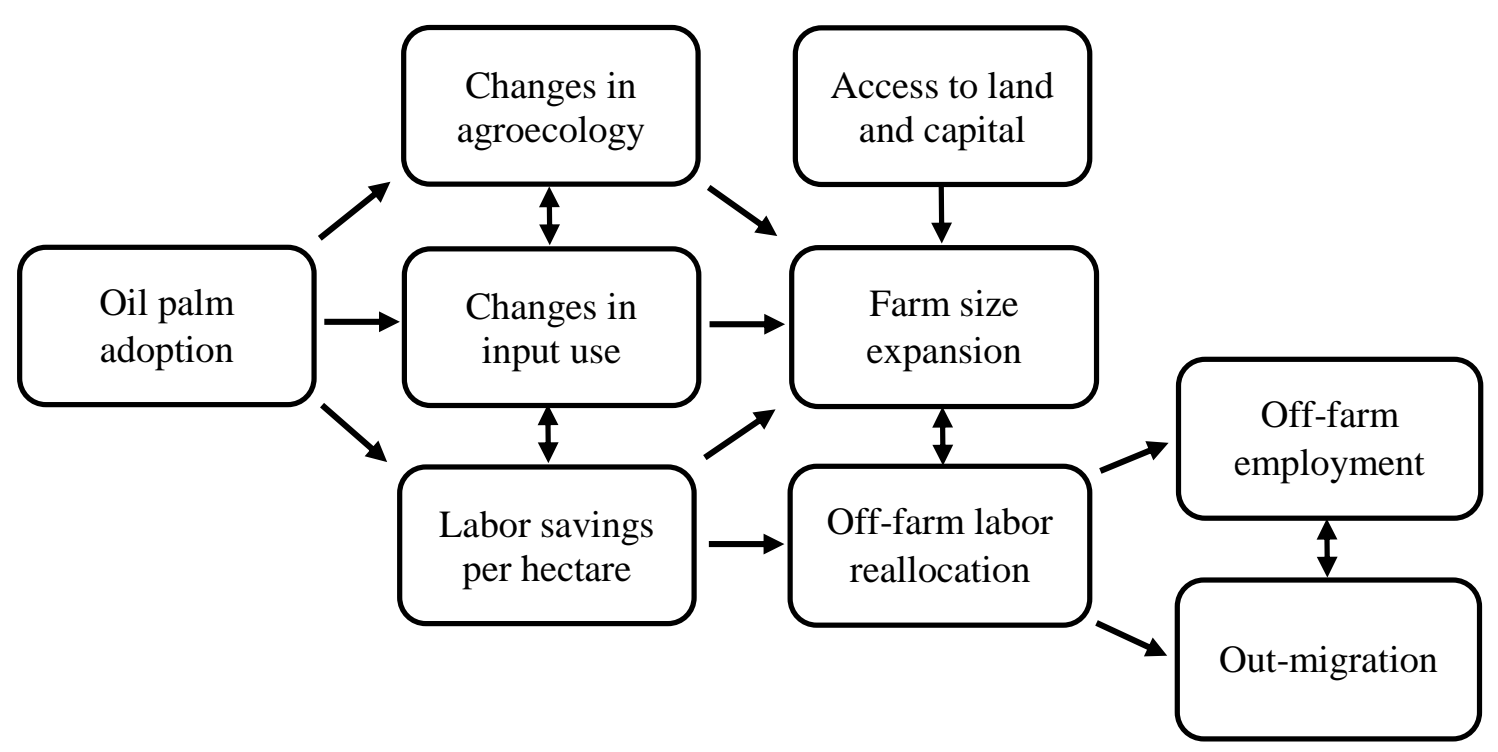

Figure 4 Oil palm adoption and structural transformation (possible mechanisms)

Oil palm adopters in Indonesia often use more chemical inputs - such as fertilizer and herbicides - than farmers growing rubber or other traditional crops (Darras et al., 2019). In contrast, oil palm requires much less labor than most traditional crops. Using survey data from Jambi, Chrisendo et al. (2020) showed that farmers who adopted oil palm use significantly less labor per hectare than non-adopting farmers. In principle, the labor time saved per hectare of land can be used in different ways, either by expanding the fam size and cultivating additional land, or by pursuing off-farm activities. Both options can lead to further household income increases on top of the profit gains per hectare of land (Krishna et al., 2017a).

Which of the labor reallocation strategies an oil palm adopting household pursues will depend on the individual opportunities in the local setting. Expanding the farm size depends on access to additional land and capital. Capital can be saved or sometimes also obtained through credit markets. Additional land can be obtained through land market transactions. Alternatively, 
farmers in Jambi sometimes convert previous fallow land or forestland (Krishna et al., 2017b). If additional land and capital are not available or accessible, the labor saved per hectare will rather be reallocated to off-farm economic activities. Employment in manufacturing or the services sector is often more lucrative than agricultural work, but presupposes that related jobs are available and accessible in the local context. This also depends on educational levels. Other options are self-employment in own non-agricultural businesses or out-migration of family members to pursue more lucrative jobs in urban centers (Kreager, 2006; de Brauw et al., 2014). Obviously, the conditions can change over longer periods of time. For instance, oil palm adopters who benefit economically may invest more into the education of their children in order to improve access to lucrative non-farm jobs in the next generation.

We will use our panel data from farm households in Jambi Province to analyze these mechanisms, except for out-migration due to data limitations. Of course, we do not expect that all changes observed in farm sizes or off-farm employment are only driven by oil palm adoption. Many other economic and social reasons may also play a role ( $\mathrm{Li}, 2009$; Thiede \& Gray, 2017; Quetulio-Navarra et al., 2018) and have to be controlled for in the econometric analysis to the extent possible.

\subsubsection{Research hypotheses}

The first hypothesis that we want to test is that oil palm cultivation contributes to farm size expansion. We test this hypothesis by analyzing average farm sizes over time for the whole sample of farm households and also separately for oil palm adopters and non-adopters. In addition to the descriptive analysis, we run regression models of the following type:

$$
F S_{i, t}=\alpha_{1}+\beta_{1} O P_{i, t}+\gamma_{1} Z_{i, t}+\delta_{1} T_{t}+\varepsilon_{i, t}
$$

where $F S_{i, t}$ is the farm size measured in terms of hectares of land cultivated by farm household $i$ in time period $t$, and $O P_{i, t}$ is a dummy variable that captures whether or not household $i$ was involved in own oil palm cultivation in time period $t .{ }^{10} Z_{i, t}$ is a vector of control variables, which may include time-variant and time-invariant factors. We also include time fixed effects, $T_{t}$, to control for general trends. Finally, $\varepsilon_{i, t}$ is a random error term. We are particularly

\footnotetext{
${ }^{10}$ It is also possible that farm size expansion happens with a certain time lag, for instance, when farmers first need to accumulate capital before they can access additional land and establish a new plantation. We therefore also run an alternative specification with $O P_{i, t-1}$ as explanatory variable.
} 
interested in the coefficient estimate $\beta_{1}$; a positive and significant estimate would support the first hypothesis that oil palm cultivation contributes to farm size expansion.

Our second hypothesis is that oil palm cultivation increases the households' involvement in offfarm employment. Again, we start the analysis with descriptive statistics by comparing offfarm employment participation between oil palm adopting and non-adopting households. In addition, we run regression models of the following type:

$$
O F E_{i, t}=\alpha_{2}+\beta_{2} O P_{i, t}+\gamma_{2} Z_{i t}+\delta_{2} T_{t}+\varepsilon_{i, t}
$$

where $O F E_{i, t}$ denotes participation in off-farm employment activities of household $i$ in time period $t$. The other variables are defined as above. A positive and significant estimate for $\beta_{2}$ would support our second hypothesis that oil palm cultivation increases participation in offfarm employment. ${ }^{11}$

Off-farm employment of farm households is a very broad concept that can include low-paying agricultural work on farms or plantations owned by others, more lucrative jobs in different nonagricultural sectors, or self-employment in own non-farm businesses. We estimate separate models for different types of off-farm activities and expect positive effects of oil palm cultivation especially for the potentially more lucrative ones.

\subsubsection{Panel data estimators}

The panel data models in equations (8) and (9) include a time dimension, so that using ordinary least squares (OLS) for estimation would be inappropriate. In principle, the models can be estimated with a random effects (RE) panel estimator. The RE estimator leads to efficient estimates as it exploits the data variation within and between households. However, RE estimates may be biased when there is unobserved heterogeneity. In fact, unobserved heterogeneity is likely, because oil palm adoption, our main explanatory variable of interest, is not distributed randomly. Farmers decide themselves whether or not to adopt oil palm based on various observed and unobserved characteristics, which will likely lead to non-random selection bias. To reduce such bias, we use a fixed effects (FE) panel estimator, which only relies on the data variation within households over time, such that any unobserved factors that

\footnotetext{
${ }^{11}$ For the effect of oil palm adoption on off-farm employment we do not expect significant time lags, as starting off-farm employment does not require large amounts of capital. Some capital is required when starting selfemployed business activities, but the local businesses typically start very small and then grow organically when being lucrative.
} 
do not vary over time cancel out (Wooldridge, 2002). ${ }^{12}$ While we estimate and show both RE and FE models, we rely on the FE estimates for interpretation, as these are more reliable in terms of reducing self-selection bias.

The model in equation (8) has farm size as dependent variable, which is continuous. In contrast, the model in equation (9) has off-farm participation as dependent variable, which is binary. For cross-section data models with binary dependent variables, probit or logit specifications are typically used. However, panel data logit or probit models are not straightforward to estimate with household FE, so that we estimate linear probability models, which is a common approach in panel data models with binary dependent variables (Wooldridge, 2002). In order to test whether the linear functional form leads to any bias, we use RE logit models as a robustness check. Moreover, as we look at households' involvement in different off-farm activities, we also use a multivariate probit (MVP) specification as another robustness check, as the MVP model controls for possible error term correlation (Greene, 2012). ${ }^{13}$

\subsection{Data and definition of key variables}

\subsubsection{Household panel survey}

We conducted a survey of farm households in Jambi Province, Sumatra Island, Indonesia, in three rounds; in 2012, 2015, and 2018. As described above, Jambi is one of the hotspots of the recent oil palm boom in Indonesia. Farm households to be included in the survey were selected through a multi-stage sampling procedure. Five regencies in Jambi, which cover the largest part of the Province's lowland areas, were chosen purposively, namely Muaro Jambi, Batanghari, Sarolangun, Tebo, and Bungo. In each regency, we randomly selected four districts. In each district, we randomly selected two villages, resulting in a total of 40 villages. In addition, five villages were chosen purposively, in order to better align with some ongoing natural science research activities (Drescher et al., 2016; Grass et al., 2020). Depending on village size, 6-24 farm households were randomly selected in each of the 45 villages. In the regression models,

\footnotetext{
${ }^{12}$ When household fixed effects and dummy variables for the time periods are included, as we do in our estimations of equations (8) and (9), the FE panel data estimator is essentially the same as the difference-in-difference estimator (Wing et al., 2018).

${ }^{13}$ Note that the MVP model is better suited than multinomial probit or logit models in our context, as households can be involved in different off-farm activities simultaneously.
} 
we control for the non-randomly selected villages. Otherwise, the sample is representative of farm households in the lowland areas of Jambi Province (Euler et al., 2017). ${ }^{14}$

Details of the number of farms included in the sample are shown in Table 7. In the first survey round in 2012, we sampled a total of 684 farm households, of which $35 \%$ had adopted oil palm, while the others had not. In 2015 and 2018, we revisited the same households for the second and third survey rounds. Oil palm adoption rates increased to $46 \%$ in 2018. Some sample attrition occurred over time, but the attrition rates remained relatively small; $6 \%$ in 2015 and $4.5 \%$ in 2018 . Attrition households were replaced by randomly sampling additional households in the same villages.

Table 7 Number of farm households included in the panel survey

\begin{tabular}{lcccc}
\hline & $\mathbf{2 0 1 2}$ & $\mathbf{2 0 1 5}$ & $\mathbf{2 0 1 8}$ & Total \\
\hline Total number of farm households & 684 & 687 & 689 & 2,060 \\
Oil palm adopters & 240 & 249 & 318 & 807 \\
Non-adopters & 444 & 438 & 371 & 1,253 \\
\hline
\end{tabular}

In all three survey rounds, face-to-face interviews were conducted with the household head using carefully designed and pre-tested structured questionnaires. The interviews were conducted in Bahasa Indonesia by a team of local enumerators who were selected, trained, and supervised by the researchers. The survey questions covered detailed information about general farm and household characteristics, agricultural and non-agricultural economic activities, and household consumption to measure living standards. In addition to information for the three survey years, we also included a few recall questions on land use in previous years, ranging back to the 1990s. Of course, answers to these longer-term recall questions may not be very precise and should be interpreted with some caution. For the regression models, we only use data from the three survey years $(2012,2015$, and 2018), but for the descriptive analysis of farm size developments, the longer-term historical data can provide interesting additional insights.

\footnotetext{
${ }^{14}$ Note that we did not survey large company plantations, as these do not belong to local farm households. Large company plantations account for around $60 \%$ of the total oil palm area in Indonesia and around $40 \%$ in Jambi Province. Our sample is representative of local family farm households, but not of all agricultural production in the province.
} 


\subsubsection{Measuring farm size}

The first key outcome variable of our study is farm size. We measure farm size in terms of the number of hectares cultivated by the farm household in a particular year. The number of hectares cultivated may differ from the number of hectares owned, but land owned can be a somewhat ambiguous concept in the local setting, where many farmers do not have formal land titles and forest encroachment is common to obtain additional land for cultivation (Krishna et al., 2017b). For the regression models, we use the number of hectares cultivated in a particular year by an individual farm household as dependent variable. For the descriptive analysis, we look at average farm size developments in our sample over time.

We use three different measures of average farm size, namely the sample mean, the median, and the hectare-weighted median, which is also called the sample mid-point. The mean and the median are commonly used indicators in analyses of farm size structures (Eastwood et al., 2010; Lowder et al., 2016). They are particularly useful when the number of farms is distributed symmetrically across different farm sizes. However, when the farm-size distribution is skewed, using the mean or the median can create a downward bias in average farm size estimates (Lund $\&$ Price, 1998). Structural transformation is often characterized by the presence of numerous small farms, which operate small fractions of the total land and have low shares in total production, and a much smaller number of large farms, which cultivate much of the total land and produce much of the total agricultural output (Adamopoulos \& Restuccia, 2014; Jayne et al., 2016).

The mid-point indicator can be used to overcome some of the limitations of the mean and the median in capturing the degree of land-use concentration (MacDonald et al., 2013). For $n$ distinct ordered farm sizes $x_{1}, x_{2}, \ldots, x_{n}$ with positive weights $w_{1}, w_{2}, \ldots, w_{n}$ such that $\sum_{i=1}^{n} w_{i}=1$, the weighted median, or the mid-point, is the farm size $x_{k}$ satisfying:

$$
\sum_{i=1}^{k-1} w_{1} \leq \frac{1}{2} \text { and } \sum_{i=k+1}^{n} w_{1} \leq \frac{1}{2}
$$

In other words, the mid-point corresponds to a farm size that separates farmers into two parts, where $50 \%$ of the total farm area is operated by farms that are smaller and $50 \%$ by farms that are larger than the mid-point (Bokusheva \& Kimura, 2016). 


\subsubsection{Measuring off-farm employment}

The second key outcome variable in our analysis is participation in off-farm employment. We measure whether or not a household or any of its members is involved in off-farm economic activities through different dummy variables. As quite different off-farm employment activities are possible, we differentiate between employed activities and self-employment in own nonfarm businesses, such as transport, trade, and handicrafts. For employed activities, we further differentiate between sectors, including jobs in (i) agriculture and forestry, (ii) manufacturing, construction, and mining, and (iii) services, including transport, health, education, and government offices.

We include both formal and informal jobs, recognizing that some informal short-term employment may possibly not be perfectly recorded in the survey data (Schneider, 2014). The separation of employment by sector is an attempt to capture potential differences in returns to skill (Herrendorf et al., 2014). We expect that off-farm employment in agriculture and forestry is the least lucrative option, whereas employment in non-agricultural sectors and selfemployment are activities with relatively higher payoffs. While this may not be perfectly true in all cases, this is a common general assumption made in the literature (Duarte \& Restuccia, 2010; Berger \& Frey, 2016).

\subsection{Results and discussion}

\subsubsection{Oil palm and farm size}

\section{Descriptive analysis}

We now want to test the first hypothesis, namely that oil palm cultivation contributes to farm size expansion. Figure 5 shows the development of the average size of farms in our sample from Jambi between 1998 and 2018, measured in terms of the sample mean, median, and midpoint. All three indicators show that the average farm size increased over time. The median farm size increased by 50\%, from about 2 ha in 1998 to 3 ha in 2018. The mean farm size is larger and increased from 3.7 ha to 4.8 ha during the same period. The mid-point is still larger and increased from 5 ha in 1998 to 8 ha in 2018, with an accelerated increase during the last ten years. 


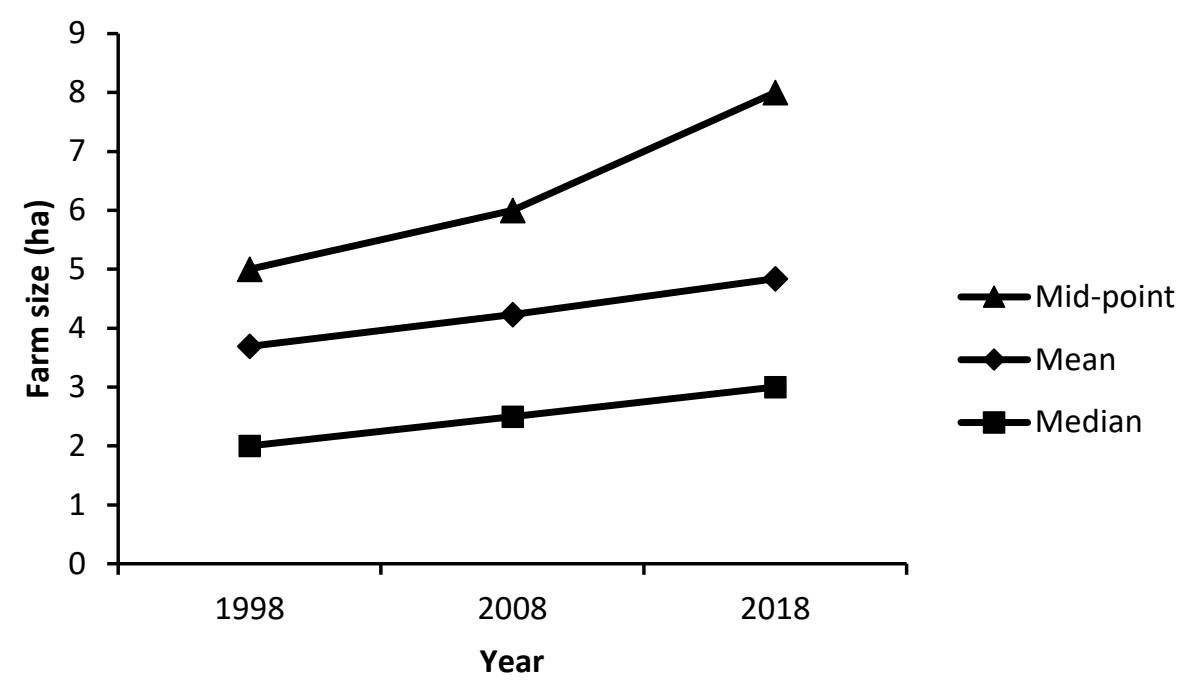

Figure 5 Development of average farm size in Jambi (1998-2018)

The notable difference between the sample mid-point and mean is due to the fact that the distribution of farms across farm size categories is not symmetrical. In 1998, farms with less than 4 ha of land accounted for $70 \%$ of all farms. This share declined somewhat over time, but in 2018 more than $60 \%$ of all farms still had a size of less than 4 ha (Figure A.1 in the Appendix). The share of large farms with more than 12 ha of land is low, but it doubled from $4 \%$ in 1998 to $8 \%$ in 2018 . These farms above 12 ha now account for almost $40 \%$ of the total land cultivated by farm households in Jambi. Hence, there seems to be a profound structural transformation, which is not fully reflected by the development of mean farm sizes.

Further insights can be gained when analyzing the development of farm size distributions and land inequality with the Gini index. Based on our sample data, the Gini index for land was 0.46 in 1998 and increased to 0.52 in 2018 . The rising inequality in the land distribution indicates a certain trend towards polarization of the farm structures. While larger farms further increase their scale of operation, many of the small farms continue to produce rather than leaving the sector. This is possible because forest and fallow land was still available in Jambi over the last 20 years, meaning that some farms could grow even without other farms exiting the sector. Figure A.2 in the Appendix shows that the total land cultivated by sample farms increased significantly between 1998 and 2018. Only since 2012, the total area cultivated did not grow further, mainly because some of the rubber plantations were cut and partly converted to oil palm. 
The analysis so far suggests that there is an ongoing structural transformation of agriculture in Jambi, but it is not yet clear to what extent this transformation is linked to oil palm cultivation. As mentioned, oil palm adoption rates in our sample increased over time. By $2018,46 \%$ of the farm households were cultivating oil palm. Figure 6 shows the development of average farm sizes in terms of sample mid-points, separately for oil palm adopters and non-adopters. For nonadopters, who are primarily cultivating rubber, the average farm size slightly increased between 1998 and 2008, but remained more or less stagnant since then. In contrast, for oil palm adopters we see a much more rapid and continuous increase in average farm sizes over time. This is a clear indication that oil palm cultivation contributes to farm size expansion, as hypothesized.

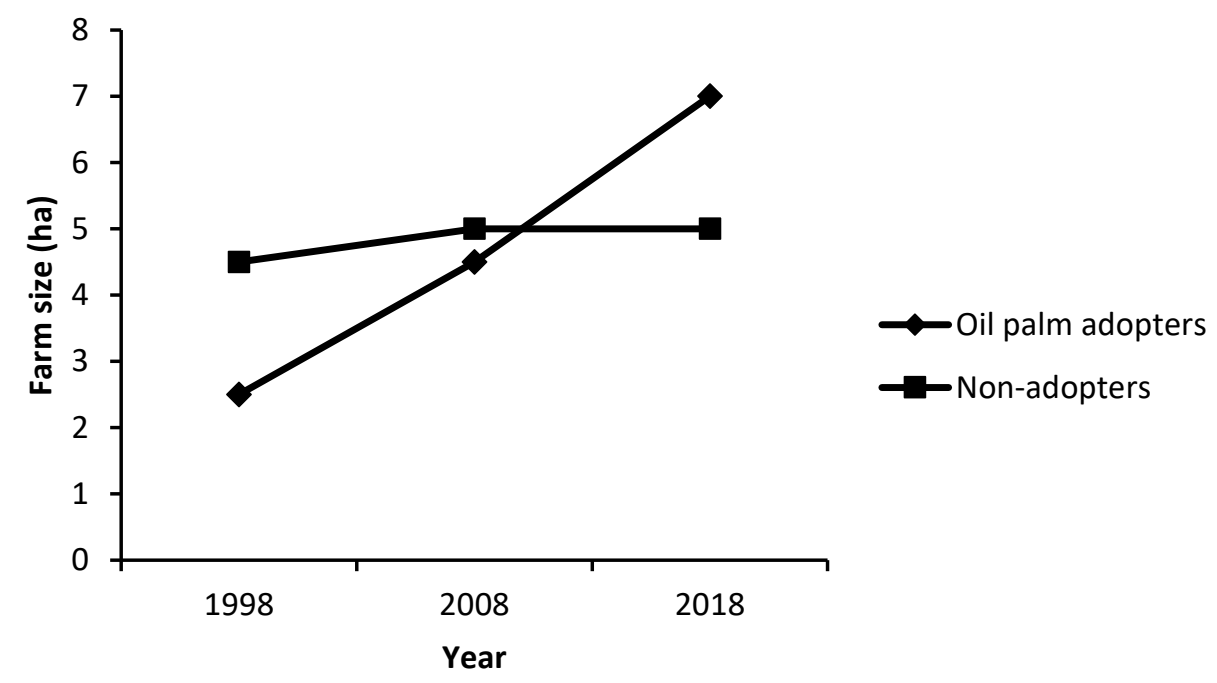

Figure 6 Development of mid-point farm sizes in Jambi for oil palm adopters and non-adopters (1998-2018)

\section{Econometric analysis}

We now analyze the role of oil palm cultivation for farm size expansion more formally, by regressing farm size on oil palm adoption and other control variables and exploiting the panel structure of our data, as explained above in equation (8). We express farm size in logarithmic terms for better empirical fit. Hence, the coefficient estimates can be interpreted in percentage terms. The estimation results are shown in Table 2.

Column (1) of Table 8 shows RE estimates. The oil palm adoption coefficient is positive, relatively large, and highly statistically significant. However, as discussed, the RE estimate may possibly suffer from selection bias. The FE estimator better controls for such bias, with results 
shown in column (2) of Table $8 .{ }^{15}$ The FE estimates confirm the positive and significant effects oil palm adoption on farm size. After controlling for other relevant factors, oil palm adoption leads to an average increase in farm size by almost $30 \%$. This is plausible and supports our first hypothesis. As oil palm requires less labor per hectare than relevant alternative crops, oil palm adopters can increase their farm size and cultivate more land. Farm size expansion would not be an easy option in settings where land availability is limited. However, as discussed, in Jambi many farms could access additional land without major constraints in the past.

Table 8 Determinants of farm size (panel data regression models)

\begin{tabular}{|c|c|c|c|}
\hline Variable & $\begin{array}{l}(1) \\
\text { RE }\end{array}$ & $\begin{array}{l}(2) \\
\text { FE }\end{array}$ & $\begin{array}{c}(3) \\
\text { RE (lagged) }\end{array}$ \\
\hline Oil palm adoption (dummy) & $\begin{array}{c}0.339 * * * \\
(0.027)\end{array}$ & $\begin{array}{c}0.294 * * * \\
(0.031)\end{array}$ & $\begin{array}{c}0.347 * * * \\
(0.040)\end{array}$ \\
\hline Government land titles (dummy) & $\begin{array}{c}0.007 \\
(0.024)\end{array}$ & $\begin{array}{l}-0.014 \\
(0.025)\end{array}$ & $\begin{array}{c}0.102 * * \\
(0.043)\end{array}$ \\
\hline Age of household head (years) & $\begin{array}{c}0.006 * * * \\
(0.001)\end{array}$ & $\begin{array}{c}0.003 \\
(0.002)\end{array}$ & $\begin{array}{c}0.011 * * * \\
(0.002)\end{array}$ \\
\hline Education of household head (years) & $\begin{array}{c}0.009 * * \\
(0.004)\end{array}$ & $\begin{array}{l}-0.003 \\
(0.005)\end{array}$ & $\begin{array}{c}0.030 * * * \\
(0.005)\end{array}$ \\
\hline Female-headed household (dummy) & $\begin{array}{c}-0.041 \\
(0.042)\end{array}$ & $\begin{array}{l}-0.003 \\
(0.046)\end{array}$ & $\begin{array}{c}-0.217 * * * \\
(0.077)\end{array}$ \\
\hline Household size & $\begin{array}{c}0.014 * * \\
(0.007)\end{array}$ & $\begin{array}{l}0.013^{*} \\
(0.007)\end{array}$ & $\begin{array}{c}0.014 \\
(0.012)\end{array}$ \\
\hline Migrant household (dummy) & $\begin{array}{l}-0.089^{*} \\
(0.046)\end{array}$ & & $\begin{array}{c}-0.118 * * * \\
(0.040)\end{array}$ \\
\hline Access to credit (dummy) & $\begin{array}{c}0.053 * * * \\
(0.019)\end{array}$ & $\begin{array}{c}0.043 * * \\
(0.019)\end{array}$ & $\begin{array}{c}0.102 * * \\
(0.043)\end{array}$ \\
\hline Non-random village (dummy) & $\begin{array}{c}0.299 * * * \\
(0.066)\end{array}$ & & $\begin{array}{c}0.328 * * * \\
(0.056)\end{array}$ \\
\hline Survey round 2015 (dummy) & $\begin{array}{l}-0.015 \\
(0.015)\end{array}$ & $\begin{array}{l}-0.007 \\
(0.016)\end{array}$ & $\begin{array}{l}-0.053 \\
(0.037)\end{array}$ \\
\hline Survey round 2018 (dummy) & $\begin{array}{c}-0.084 * * * \\
(0.023)\end{array}$ & $\begin{array}{c}-0.045^{*} \\
(0.024)\end{array}$ & \\
\hline Constant & $\begin{array}{c}0.933 * * * \\
(0.086)\end{array}$ & $\begin{array}{c}1.209 * * * \\
(0.095)\end{array}$ & $\begin{array}{c}0.558 * * * \\
(0.118)\end{array}$ \\
\hline Number of observations & 2,060 & 2,060 & 1,301 \\
\hline
\end{tabular}

Notes: Farm size as the dependent variable is measured in hectares and expressed in logarithmic terms. Coefficient estimates of panel data models are shown with standard errors in parentheses. ${ }^{a}$ The model in column (3) uses observations from only two survey rounds (2015 and 2018) and considers oil palm adoption in lagged form (t-1), meaning adoption in the previous survey round. $*, * * * * *$ significant at the $10 \%, 5 \%$, and $1 \%$ level, respectively.

Column (3) in Table 8 shows an alternative specification where oil palm adoption is included in lagged form. Lagged oil palm adoption also leads to a significantly positive effect on farm size. The effect size is even somewhat larger, suggesting that - beyond the labor savings -

\footnotetext{
${ }^{15}$ Note that time-invariant variables, such as household migration background or village fixed effects, cancel out in FE estimation.
} 
capital accumulation over time among the oil palm adopters may also be a relevant mechanism for farm size expansion. The important role of capital for expanding the farm size is also underlined by the positive and significant effect of access to credit and government land titles in column (3) of Table 8. Also beyond the oil palm context, access to credit is often positively associated with innovation adoption and farm size (Mariyono, 2019a; Mariyono, 2019b).

\subsubsection{Oil palm and off-farm employment}

\section{Descriptive analysis}

We now turn to our second hypothesis, namely that oil palm cultivation increases farm households' involvement in off-farm employment. Table 9 shows descriptive statistics for oil palm adopters and non-adopters in our sample. Oil palm adopters enjoy significantly higher living standards than non-adopters, as can be seen from the comparison of household consumption expenditures. Previous research showed that oil palm adoption contributes to significant gains in household living standards (Euler et al., 2017; Krishna et al., 2017a). As can also be seen in Table 9, oil palm farmers spend a much lower amount of time per hectare of farmland than non-adopters. Some of the labor saved per hectare is spent on cultivating additional land, as was shown above. But are oil palm adopters also reallocating saved labor time to off-farm activities? Significant differences in annual off-farm income between adopters and non-adopters suggest that they do (Figure 7). But the rates of participation in different offfarm activities show a somewhat mixed picture (Table 9).

Participation rates in all off-farm activities combined do not differ between oil palm adopters and non-adopters (Table 9). For employed activities, the rates are even somewhat lower among the oil palm adopters, which is driven by their lower participation in agricultural off-farm jobs. This is unsurprising, as agricultural employment is often not particularly lucrative and more common among poor and unskilled workers (Bou Dib et al., 2018b; Martinez et al., 2014; Schaner \& Das, 2016). Participation in manufacturing and services jobs does not differ significantly between oil palm adopters and non-adopters. However, oil palm adopters participate significantly more in self-employed activities. 
Table 9 Household characteristics of oil palm adopters and non-adopters

\begin{tabular}{lcc}
\hline Variables & Oil palm adopters & Non-adopters \\
\hline Household consumption expenditures (million IDR/AE/year) & $15.260^{* * *}$ & 11.432 \\
Labor time spent on-farm (hours/ha/year) & $(12.212)$ & $(8.140)$ \\
Household off-farm income (million IDR/AE/year) & $278.313 * * *$ & 1143.799 \\
& $(449.138)$ & $(1749.826)$ \\
Participation in off-farm activities (dummy) & $7.932 * * *$ & $(10.910)$ \\
& $(16.487)$ & 0.667 \\
Employed activities (dummy) & 0.669 & $(0.471)$ \\
Agriculture/forestry (dummy) & $(0.471)$ & 0.545 \\
& $0.494 * *$ & $(0.498)$ \\
Manufacturing/construction/mining (dummy) & $(0.500)$ & 0.238 \\
Services (dummy) & $0.198 * *$ & $(0.426)$ \\
& $(0.399)$ & 0.140 \\
Self-employed business activities (dummy) & 0.123 & $(0.347)$ \\
Number of observations & $(0.328)$ & 0.168 \\
\hline
\end{tabular}

Notes: Mean values are shown with standard deviations in parentheses. Observations from all three survey rounds were pooled. Monetary values were deflated using the consumer price index for Indonesia to allow comparison across survey rounds. In 2012, 1 US\$ was equivalent to IDR 9,670. AE, adult equivalent. Mean differences between adopters and non-adopters were tested for statistical significance. $* *$, *** significant at the $5 \%$ and $1 \%$ level, respectively.

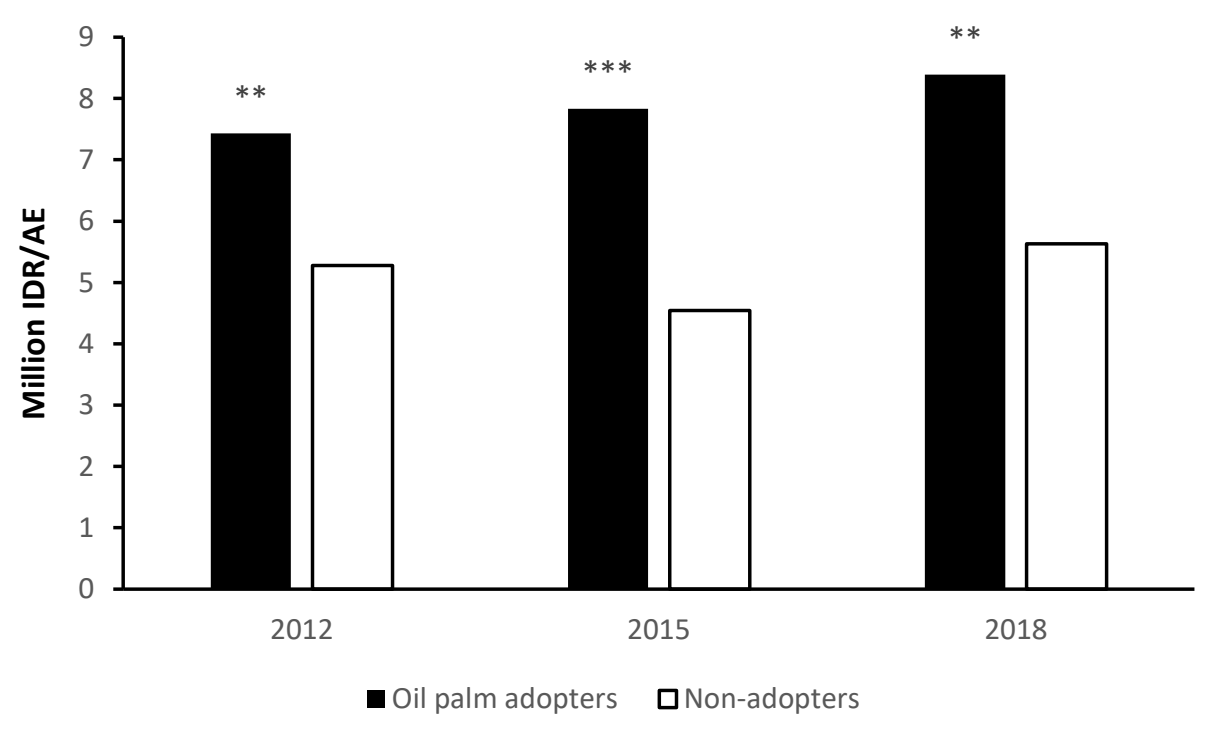

Figure 7 Annual off-farm income of oil palm adopters and non-adopters (2012-2018)

Notes: AE, adult equivalent. $* *, * * *$ difference is statistically significant at the $5 \%$ and $1 \%$ level, respectively. 


\section{Econometric analysis}

We now run regression models to test our second hypothesis more formally. Table 10 shows results of linear probability models with household participation in different off-farm activities as dependent variable, as explained in equation (9). For brevity, we only show the FE specifications (RE results are shown in Table A.7 in the Appendix with similar results). Oil palm adoption does not significantly affect household participation in any of the employed offfarm activities. However, it significantly increases participation in self-employed activities, including small businesses in transport, trading, and handicrafts, among others. The estimates in Table 10 imply that - after controlling for other factors - oil palm adoption increases the probability of pursuing self-employed business activities by 17.5 percentage points. ${ }^{16}$ Insignificant effects of oil palm adoption on employed off-farm activities and significantly positive effects on self-employed activities are also found when using RE logit models and a multivariate probit as robustness checks (Tables A.8 and A.9 in the Appendix). Hence, the results do not seem to be driven by the choice of functional form.

That we see no significant effect of oil palm adoption on employed off-farm activities may surprise, given that oil palm requires considerably less labor per hectare of land. Possibly, our off-farm participation dummies are not sufficiently sensitive, as they do not capture the actual time that household members spent in off-farm activities. Unfortunately, we do not have more detailed time allocation data for off-farm activities. However, there is also a plausible reason why no effect on employed off-farm activities is observed, namely the lack of lucrative nonagricultural employment opportunities in the local setting. While Jambi City, the Province's Capital, is a vibrant place with many employment opportunities in manufacturing and services, it takes too long to reach the City for a daily commute from most of the Province's rural areas. In the rural areas themselves and in smaller towns nearby, the job opportunities are much more limited.

The limited employment opportunities in rural areas of Jambi have several implications that do not bode well for sustainable development. First, without lucrative non-agricultural employment options, marginal farms will continue to produce rather than exiting the sector. Second, oil palm adopters have a higher incentive for increasing their farm size in order to use the saved labor time productively. At least in the past, farm size expansion was often associated

\footnotetext{
${ }^{16}$ In the models in Table 4, we control for farm size (land cultivated). As farm size is influenced by oil palm adoption, we ran the same models also without controlling for farm size as a robustness check. The effect of oil palm adoption remains very similar: insignificant for employed activities and a significant point estimate of 0.175 for self-employed activities.
} 
with additional deforestation and concomitant negative effects for biodiversity and climate change. Third, farmers with access to capital can resort to self-employed business activities, but this option is much less accessible for poor and credit-constrained households. Improving offfarm employment options could therefore help to avoid rising inequality and environmental problems.

Table 10 Determinants of participation in off-farm activities (FE panel data models)

\begin{tabular}{|c|c|c|c|c|}
\hline \multirow[b]{2}{*}{ Variables } & \multicolumn{3}{|c|}{ Employed activities } & \multirow[b]{2}{*}{ Self-employec } \\
\hline & Agriculture & Manufacturing & Services & \\
\hline \multirow[t]{2}{*}{ Oil palm adoption (dummy) } & -0.046 & 0.009 & 0.028 & $0.175^{* * *}$ \\
\hline & $(0.041)$ & $(0.037)$ & $(0.037)$ & $(0.040)$ \\
\hline \multirow[t]{2}{*}{ Farm size (land cultivated in ha) } & -0.002 & -0.003 & 0.002 & $-3.183 e-4$ \\
\hline & $(0.004)$ & $(0.003)$ & $(0.003)$ & $(0.003)$ \\
\hline \multirow[t]{2}{*}{ Female-headed household (dummy) } & 0.025 & $0.166 * * *$ & 0.002 & $-0.102 *$ \\
\hline & $(0.061)$ & $(0.055)$ & $(0.055)$ & $(0.059)$ \\
\hline \multirow[t]{2}{*}{ Household size } & $0.022 * *$ & $0.019 * *$ & $0.040 * * *$ & $0.024 * * *$ \\
\hline & $(0.009)$ & $(0.008)$ & $(0.008)$ & $(0.009)$ \\
\hline \multirow[t]{2}{*}{ Age of household head (years) } & 0.001 & 0.003 & $-2.551 \mathrm{e}-4$ & 0.002 \\
\hline & $(0.002)$ & $(0.002)$ & $(0.002)$ & $(0.002)$ \\
\hline \multirow[t]{2}{*}{ Education of household head (years) } & $0.015 * *$ & 0.005 & -0.002 & 0.003 \\
\hline & $(0.006)$ & $(0.006)$ & $(0.006)$ & $(0.006)$ \\
\hline \multirow[t]{2}{*}{ Access to credit (dummy) } & $0.045^{*}$ & -0.015 & -0.008 & $0.087 * * *$ \\
\hline & $(0.026)$ & $(0.023)$ & $(0.024)$ & $(0.025)$ \\
\hline \multirow[t]{2}{*}{ Distance to market $(\mathrm{km})$} & 0.001 & 0.002 & 0.001 & -0.002 \\
\hline & $(0.002)$ & $(0.002)$ & $(0.002)$ & $(0.002)$ \\
\hline \multirow[t]{2}{*}{ Survey round 2015 (dummy) } & 0.008 & $0.083 * * *$ & 0.010 & $0.063 * * *$ \\
\hline & $(0.021)$ & $(0.019)$ & $(0.019)$ & $(0.020)$ \\
\hline \multirow[t]{2}{*}{ Survey round 2018 (dummy) } & 0.003 & $-0.048 * *$ & $0.133 * * *$ & 0.034 \\
\hline & $(0.024)$ & $(0.022)$ & $(0.022)$ & $(0.023)$ \\
\hline \multirow[t]{2}{*}{ Constant } & -0.037 & -0.123 & -0.038 & -0.075 \\
\hline & $(0.129)$ & $(0.116)$ & $(0.117)$ & $(0.125)$ \\
\hline R-squared & 0.012 & 0.052 & 0.062 & 0.048 \\
\hline Number of observations & 2,060 & 2,060 & 2,060 & 2,060 \\
\hline
\end{tabular}

Notes: Coefficient estimates of linear probability models with fixed effects are shown with standard errors in parentheses. $*, * *, * * *$ significant at the $10 \%, 5 \%$, and $1 \%$ level, respectively.

\subsection{Conclusion}

With economic growth and development, countries typically experience a structural transformation where the agricultural sector shrinks in relative importance while the manufacturing and service sectors grow. Two important characteristics of this transformation 
within the agricultural sector are the expansion of average farm sizes and the reallocation of agricultural labor to other sectors. This process is often supported by the adoption of productivity-increasing and labor-saving agricultural innovations. In this article, we analyzed to what extent the adoption and cultivation of oil palm contributes to structural transformation in Indonesia. Indonesia has seen a rapid expansion of oil palm cultivation in recent decades. The country is now the biggest palm oil producer and exporter worldwide. The crop is partly grown on large company plantations, but over $40 \%$ of the oil palm area in Indonesia is also managed my small- and medium-sized family farms. We focused on these family farms to examine the effects of oil palm cultivation on farm size developments and participation in offfarm activities.

Our panel data from Jambi Province show that oil palm adoption and cultivation contribute to gains in household living standards and labor savings per hectare of land. Oil palm requires much less labor per hectare than alternative crops such as rubber. Our first research hypothesis was that oil palm cultivation increases average farm sizes over time, because some of the labor saved per hectare would be used to cultivate additional land. This hypothesis was confirmed. Average farm sizes increased significantly over the last 20 years, and especially so among the oil palm adopters. Panel data models with household fixed effects suggest that oil palm adoption increased farm sizes by $30 \%$ on average, after controlling for other factors that may also influence the scale of operation.

Our second hypothesis was that oil palm cultivation increases farm households' participation in off-farm employment, assuming that some of the labor saved would also be reallocated to non-agricultural activities. This hypothesis was confirmed only partly. Oil palm adopters have significantly higher off-farm incomes than non-adopters. However, when looking at participation rates in different types of off-farm activities we only found significant effects of oil palm adoption on self-employment in small family-run businesses, but not on external employment in manufacturing or services. The reason is probably that insufficient nonagricultural employment opportunities exist in the local rural setting.

Overall, we conclude that oil palm contributes to structural transformation of agriculture in Indonesia. Yet more policy attention may be needed to guide related developments in terms of sustainability and equity. The limited non-agricultural employment opportunities in rural areas may prevent marginal farms from exiting the sector. Moreover, oil palm farmers with limited options to reallocate their time to lucrative off-farm employment have a strong incentive for increasing their farm size instead. Especially when these farmers cannot purchase or rent land 
from exiting farms, they may further encroach forests with negative environmental effects. Selfemployed business activities are an option for better-off households with access to capital and entrepreneurial skills, but are much less accessible for poor households with low educational levels. Hence improving off-farm employment opportunities as well as credit and vocational training options may be useful policies to avoid undesirable sustainability outcomes. 


\title{
4. Does oil palm cultivation improve the long-term wellbeing of smallholder farm households? ${ }^{17}$
}

\begin{abstract}
Despite its profound implications for the environment and biodiversity, oil palm cultivation was shown to increase smallholder farmers' income. Yet, little is known if this economic benefit contributes to households' long-term wellbeing. This study analyzes the effects of oil palm cultivation on different indicators of human capital formation and material resources of smallholder farm households that can help improve long-term wellbeing and living standard. We use three rounds of panel data collected in Jambi Province, Sumatra, one of the oil palm boom hotspots and one of the provinces with the highest share of smallholder farmers in Indonesia. When estimated using random-effects estimators, results show that oil palm cultivation positively affects households' nutrition, medicine expenditure, education, electricity consumption, and communication expenditure. Fixed-effects estimators also suggest similar results, although they are not always significant, possibly due to the limited variation of oil palm cultivation within households across the three survey years.
\end{abstract}

Keywords: Oil palm; Smallholder farmers; Wellbeing; Living standard; Rural development

\footnotetext{
${ }^{17}$ Acknowledgement: The author is grateful for valuable comments and suggestions from Bernhard Brümmer at the DARE doctoral seminar. The author also thanks Matin Qaim for useful feedback to improve this paper.
} 


\subsection{Introduction}

Oil palm cultivation has raised a lot of controversies because negative environmental and social effects are often attributed to its massive expansion (Grass et al., 2020; Meijaard et al., 2020). On the opposite side, some studies found positive effects of oil palm cultivation. It contributes to economic development and poverty alleviation (Rist et al., 2010; Zen et al., 2016; Qaim et al., 2020), raises farmers' income, and provides employment (Euler et al., 2017; Bou Dib et al., 2018b; Kubitza et al., 2018a; Chrisendo et al., 2020). Beyond households, oil palm expansion improved village infrastructure and facilities (Cramb \& Curry, 2012; Gatto et al., 2017). Studies about smallholder farmers are essential as their farm area accounts for more than $40 \%$ of Indonesia's oil palm plantation (Ministry of Agriculture Indonesia, 2019a).

As previous studies have successfully shown that oil palm cultivation contributes to the rising income, how the additional income is really spent has hardly been analyzed up till now. We are interested in investigating if the farmers invest income in their long-term wellbeing and living standard. Human wellbeing has become a topic of discussion to be considered an indicator of development, not only economic performance (Seaford, 2011; Steptoe et al., 2015). It is, in fact, a central of Sustainable Development Goals (SDGs) number three that aims to "ensure healthy lives and promote wellbeing for all at all ages" (UN General Assembly, 2015). While wellbeing can be subjective (e.g., feeling happy, being satisfied), it can also be approached objectively by defining it using quality of life indicators such as human capital, social attributes, and material resources that can contribute to a long-term good living standard (Western \& Tomaszewski, 2016; Ross et al., 2020).

We aim to contribute to the current literature by examining the effects of oil palm cultivation on long-term wellbeing on smallholder farmer households by using various proxies that qualify as indicators such as nutrition, health, education, housing, household assets, electricity, and connectedness. These indicators represent human capital, material resources, and social attributes that mark life quality (Ross et al., 2020). They are important because they reflect welfare acquired from the rising income, and to some extent, from the labor-saving, which is one of the main advantages of oil palm cultivation (Euler et al., 2017; Chrisendo et al., in press). To the best of our knowledge, study about the effects of oil palm cultivation on the long-term wellbeing is still very rare. Some indicators that we use have not been employed in any study before. 
We use household-level data collected by our team in Jambi province, Sumatra, one of the oil palm boom hotspots. Our data is three rounds of panel data with a gap of three years collected between 2012 and 2018. We employ random effects (RE) and fixed effects (FE) estimator to analyze the impact heterogeneity. The rest of this article proceeds as follows. Section 2 discusses the materials and methods, explaining the data, hypotheses, measurement of wellbeing indicators, and regression estimators. The descriptive and regression results are presented in Section 3. Section 4 concludes.

\subsection{Materials and Methods}

\subsubsection{Data}

Three rounds of farm household surveys were conducted in Jambi Province in 2012, 2015, and 2018. Jambi ranks seventh among all other Indonesian provinces in cultivated oil palm areas, where smallholder farmers cultivate around $63 \%$ of them (Ministry of Agriculture Indonesia, 2019a). This number places Jambi as one of the provinces with the highest share of smallholder oil palm farms.

We selected our sample through a multi-stage sampling procedure. Five regencies in Jambi, which cover the largest part of the lowland area, were chosen purposively, namely Muaro Jambi, Batanghari, Sarolangun, Tebo, and Bungo. In each regency, we randomly selected four districts. In each district, we randomly selected two villages that make in total 40 villages. Five villages were chosen purposively, where other project activities were conducted (Drescher et al., 2016; Grass et al., 2020). We control for the non-randomly selected villages in the regression models. Depending on the village's population size, we randomly selected 6-24 farm households in each village.

In 2012, we interviewed 684 farm households. In 2015 and 2018, we revisited the same households and conducted another interview. There were some sample attritions due to the household's unavailability, such as out-migration or the household head's decease. The attrition rate in 2015 and 2018 is 6\% and 4.5\%, respectively, which is relatively low (Schulz \& Grimes, 2002). We randomly sampled the replacement households from the village census list to replace the households with whom we could not meet in 2015 and 2018.

Before the survey was conducted, we trained our local enumerators consisting of students and graduates from the University of Jambi, Bogor Agricultural University, and other universities. 
We tested the carefully designed structured questionnaire with farmers who lived in villages close to the city. The interviews were conducted face-to-face in Bahasa Indonesia with direct supervision by the researchers. The survey questions covered general household characteristics, farming and non-farming activities, household consumption, and a range of other socioeconomic factors. The enumerators interviewed the household head or household members who know the answer best.

\subsubsection{Hypotheses}

We aim to analyze how oil palm cultivation by smallholder farmers affecting the households' long-term wellbeing. Many wellbeing definitions and descriptions have been developed (Dodge et al., 2012; Ross et al., 2020). There are different domains of wellbeing. In this study, we approach wellbeing objectively by using household nutrition, health, education, housing, household assets, electricity, and connectedness. Nutrition, health, and education are indicators of human capital formation. Housing, household assets, and electricity are material resources that signify a good living condition. Connectedness represents social attributes. We hypothesize that oil palm cultivation would have positive effects on these outcome variables that indicate the long-term wellbeing of smallholder farm households.

First, we will analyze the differences in the outcome variables mentioned above between oil palm adopters and non-adopters. And then, to test our hypotheses formally, the outcome variables are estimated at the household level with panel models of the following type:

$$
Y_{i t}=\alpha+\beta O P_{i t}+\gamma Z_{i t}+\delta T_{t}+\varepsilon_{i t}
$$

where $Y_{i t}$ is the respective outcome variable for farm household $i$ in year $t . O P_{i t}$ represents oil palm cultivation; this is dummy variable that takes a value of 1 if household $i$ cultivate oil palm in year $t$ and 0 otherwise. Therefore, $\beta$ measures the effect of oil palm cultivation. A positive and statistically significant estimate of $\beta$ would indicate that oil palm cultivation positively correlates with outcome variables. We also control for other relevant farm, household, and village characteristics that could influence the outcome variables through the vector $Z_{i t} . T_{t}$ is the time fixed effects to control for general trends. $\varepsilon_{i t}$ is a random error term.

The outcome variables are measured using different units, which will be explained in more detail in the following section. Some indicators are presented in monetary values, which are calculated yearly at the household level in the local currency, Indonesian Rupiah (IDR). The 
values are then divided by the number of male adult equivalent (AE) living in each household to allow comparison across the households. An exception is for education expenditure, is divided by the number of school-aged children in the household instead of AE. To allow comparison across the survey rounds, monetary values in 2015 and 2018 were deflated to 2012 values. Depending on the variables, they can be deflated by using consumer price index, food price index, medical care price index, education price index, electricity price index, or communication price index specific for Jambi. This distinction can provide more precise values as some variables are more volatile than others, for example, food price (Gilbert \& Morgan, 2010). In the regression analysis, we present the monetary values in logarithmic form as a response to skewness towards large values.

\subsubsection{Measurement of wellbeing indicators}

\section{Nutrition}

The first outcome variable that we use as an outcome variable is nutrition. Several studies have shown the importance of nutrition in improving adult human capital and economic productivity (Martorell et al., 2010; Zhang et al., 2013; Martorell, 2017). As adequate nutrition reduces the risk of hunger and improves immunity, work performance increases; therefore, people are pushed out of poverty (Frankenberg \& Thomas, 2017). Nutrition is also critical for physical and cognitive development among children (Black et al., 2013; Debela et al., 2020). We hypothesize positive nutrition effects of oil palm adoption due to the rising income that enables farmers to buy more nutritious food. First, we compare the total household expenditures and food expenditures between the oil palm adopters and non-adopters. The food expenditures include purchased and own-produced foods. In Jambi, own food production is not significant as farmers rely on well-established markets to satisfy their daily food needs. As for nutrition indicators, we use dietary diversity score (DDS) and calorie intake that are derived from a 7-day recall period and a list of 121 different food items customized to Jambi consumption habits. To construct DDS, we use classification recommended for women's dietary diversity score that consists of nine healthy food groups, namely (1) starchy staples; (2) dark green leafy vegetables; (3) other vitamin-A rich fruits and vegetables; (4) other fruits and vegetables; (5) organ meat; (6) meat and fish; (7) eggs; (8) legumes, nuts and seeds; (9) milk and milk products (FAO, 2011). The final DDS range between 0 to 9. 
We calculate the quantities of calories consumed by the households using food composition tables for Indonesia (Berger et al., 2013; USDA, 2016). The 7-day calorie values are converted to daily values/AE. The values of calories are presented in logarithmic. We should keep in mind that the dietary measures that we use here are at the household level. Thus, we cannot speak about individual-level diets and nutrition.

\section{Health}

Like nutrition, health is related to human capital formation and can improve wellbeing (Bleakley, 2010; Zivin \& Neidell, 2013). Household health could be denoted by health expenditure (Ke et al., 2011; Athukorala et al., 2012). The rising income from oil palm cultivation may enable farmers to access medication and invest more in health. Therefore, we hypothesize that oil palm cultivation increases health expenditure. However, higher-income does not necessarily increase health expenditure if health care facilities are not accessible around the village, which is prevalent in rural Indonesia (Parmanto et al., 2008; WHO, 2017). Farmers might have to go to another city to get health care and discouraged from doing so. Thus, it is particularly useful to breakdown the health expenditure to understand which type of health facilities and treatments are more relevant for the farmers. We look at expenditure on five different medical facilities and treatment, namely hospital, community health center, doctor clinic, traditional healer clinic, and medicine. Community health centers and traditional healers usually exist in every village. Hospitals and doctor clinics are generally available in cities. Meanwhile, the medicine expenditure here mostly covers medicine without a prescription, which is widely available in local shops in the village (Hadi et al., 2010).

Farmers in Indonesia may have their health expenditures borne by public insurance. Indonesian Law No. 24 of 2011 concerning the Social Security Organizing Agency mandates all Indonesian to participate in public insurance (Habibie et al., 2017). Even though not all Indonesian has joined the program, participation has been gradually increasing from year to year. However, we only use the health expenditure classified as out-of-pocket payment or paid directly by the farmers. As this type of expenditure prevents some households from accessing needed health care, we will be able to see the impact heterogeneity from oil palm cultivation.

Higher health expenditure can be interpreted as a proxy of wealth (Ke et al., 2011). Spending on health care can be a necessity when someone is sick, or a luxury good when someone just wants to do a regular medical check-up without any underlying health problem (Murthy \& 
Okunade, 2009; Athukorala et al., 2012). Whatever the reason, this expenditure represents farmers' investment in health. A drawback of health expenditure is it does not perfectly portray farmers' health status as some of them may never get any health care when they feel healthy. Unfortunately, we cannot control this as we do not have information on initial health status.

Higher health expenditures could also be interpreted as oil palm farmers being more often sick or possibly suffering from health issues because of oil palm farming ( $\mathrm{Li}, 2015)$. However, the health issues specifically related to oil palm cultivation are unlikely to happen in a particular context in Jambi because they were never reported by farmers, either in the surveys or other discussions.

\section{Education}

The third wellbeing indicator that we are interested in is education. Through education, one can acquire skills and competencies that are useful in life, such as decision-making skills, knowledge of rights, and workability (Ross et al., 2020). In many poor households in Indonesia, parents expect children to become economically productive at an early age, preventing them from going to school. It is common for children to work on the family farm (Hsin, 2007). When oil palm cultivation improves household economic conditions, children may be released from on-farm work, bringing them back to school. Previous studies have shown that oil palm requires less labor than rubber (Euler et al., 2017), and the type of work in oils palm plantation requires a lot of strength and energy (Chrisendo et al., in press) that may exclude children from working on the farm.

In Indonesia, the school consists of twelve years of education, divided into six years of primary school, three years of secondary school, and three years of high school. Children complete and receive a school diploma when they finish twelve years of basic school. In general, school enrollment and dropout rates can be good indicators for household education (Ha \& Mendoza, 2010; Parinduri, 2014). However, school enrollment is compulsory for all school-aged children in Indonesia whether or not they attend regularly. There is also no strict law enforced if parents fail to send the children to school or when the children drop out. This can be a drawback using school enrollment and dropout rates since parents might overreport their children's school participation. Another limitation in our dataset is that the enrollment and dropout rates data do not refer to any particular year. Because of this reason, it may be problematic to attribute these variables to oil palm cultivation causally. Expenditure on education may be a more reliable and 
accurate indicator. It refers to a particular year and is more attributable to oil palm cultivation. Education expenditure includes registration fee, tuition fee, books, uniforms, extra-curricular activities, private lessons, excursions, and contributions to the parents-teachers association, all combined in one year for each household with school-aged children.

We are also interested in the household's expenditure on higher degree education. We capture this by using outward remittances calculated for one year. There are various purposes of outremittances but mostly to support family members who live outside the village to pursue higher education. In Indonesia, universities and colleges can mostly only be found in the city. If household members want to pursue a higher degree of education, they have to move out of the village and live in the city where the university is located. The money that is sent out is used to cover the education-related costs and living costs. We hypothesize that oil palm cultivation increases the household's education expenditure and outward remittances.

\section{Housing, household assets, and electricity}

Good housing, ownership of assets, and access to electricity signify a good living condition, which is also an investment of long-term wellbeing (Mazur, 2011; Coley et al., 2013). Housing should be decent and safe on a physical level in order to provide a positive environment, stability, and security for the households (Bratt, 2002). We use wall and floor materials as indicators of good housing. Oil palm farmers who are economically better-off may have a better living space, such as a brick wall house with cemented or tiled floor, which symbolizes a more permanent and stable settlement than a wooden or clay house without flooring. Besides a good house condition, owning household assets such as television, satellite-dish, fridge, washing machine, phone, and vehicles can make one's life easier. We use a dummy variable where 1 indicates ownership and 0 if otherwise. We hypothesize that oil palm cultivating households have better housing condition and have higher ownership of household assets than the nonadopters.

On top of the housing, electricity consumption and access are also essential for improving people's wellbeing (Mazur, 2011; Ahmad et al., 2014). Electricity is widely available in rural Jambi. Yet, it is still a luxury good for some households, and the consumption is different among households. We capture electricity consumption by looking at electricity expenditure. We hypothesize that oil palm cultivation increases the household's electricity expenditure. 


\section{Connectedness}

Connectedness qualifies as a wellbeing indicator as it is related to positive social networks and relationships with others, including family, relatives, and friends (Jose et al., 2012; Western \& Tomaszewski, 2016). Principally, households' participation in social organizations, such as farmers' organizations or religious groups, can be a good indicator of connectedness (Pratiwi \& Suzuki, 2017; Ibnu et al., 2018). However, almost all our sample households are involved in at least one organization regardless of their cultivated crops. In this case, using social organization may obscure the link between oil palm adoption and connectedness.

We use the household's communication expenditure to measure connectedness objectively. We combine the yearly spending for telephone bills, mobile phone credit, and internet bills for all household members. The use of phone, internet, and social media illustrates the household's access to opportunities to become part of a network and to develop meaningful relationships by connecting people, keeping someone up to date with the latest information, and receiving extension and other services, therefore improving wellbeing (Allen et al., 2014; Pearson et al., 2017; Sekabira \& Qaim, 2017). We hypothesize that oil palm cultivation increases the household's communication expenditure due to the rising income.

\subsubsection{Regression estimators}

The models that we use include a time dimension and can be estimated with random effects (RE) and fixed effects (FE) panel estimator. We assume that there is unobserved heterogeneity within the household affects and creates a bias to the oil palm cultivation. In this case, oil palm cultivation may potentially be correlated with the error term. FE estimator will remove the effect of those time-invariant characteristics, either observed or unobserved (Wooldridge, 2002); therefore, with the interpretations from FE, we can access the net effect of the oil palm cultivation on the outcome variables. However, FE is only efficient when there are many households who adopted oil palm in one or two survey years and did not adopt oil palm in other years. If the variation in the oil palm adoption variable is not large, FE results are less efficient than RE. Meanwhile, RE estimator leads to efficient estimates as it can exploit both within and between household variation. Table 11 shows how oil palm adoption by our sample changed over three survey rounds. In 2012, around 35\% of the households had adopted oil palm. This number increased to $46 \%$ in 2018 . 
Table 11 Number of oil palm adopters and non-adopters within sample across three survey years

\begin{tabular}{lcccc}
\hline & $\mathbf{2 0 1 2}$ & $\mathbf{2 0 1 5}$ & $\mathbf{2 0 1 8}$ & Total \\
\hline Oil palm adopters & 240 & 249 & 318 & 807 \\
Non-adopters & 444 & 438 & 371 & 1,253 \\
Total number of farm households & 684 & 687 & 689 & 2,060 \\
\hline
\end{tabular}

\subsection{Results and discussion}

\subsubsection{Descriptive analysis}

Table 12 shows descriptive statistics for oil palm adopters and non-adopters from pooled data (separate comparisons by survey round can be found in Table A. 10 in the Appendix). As expected, the oil palm adopters are wealthier, indicated by significantly larger farm size and higher total household expenditure than the non-adopters. In terms of nutrition, oil palm adopters perform significantly better in all indicators. They consume more diverse food with DDS 6.9 and higher calories than the non-adopters. They have higher expenditure on food, but the share of total household expenditure on food is lower than that of the non-adopters. These findings satisfy Engel's law stating the percentage of income allocated for food purchases decreases as income rises.

The total health expenditure of oil palm adopters is $38 \%$ higher than the non-adopters, only that the difference is not statistically significant. When the health expenditure is disaggregated, this difference is also observed in some sub-categories, namely expenditure on hospitals, community health centers, and medicine. It is even significantly higher on the latter one, which is the most accessible health treatment in the village than the other health care facilities.

Table 13 compares the education variables between households of oil palm adopters and nonadopters (a breakdown by survey round is shown in Table A. 11 in the Appendix). Among the households with school-aged children, the school enrollment is very high, which is almost $100 \%$. As explained, school enrollment of school-aged children is compulsory even though they may not attend the class regularly. Along the way, we can see that some children drop out of school or those who did not complete the twelve years of schooling. The reasons can be varied from the family's low education awareness, the economic necessity that forces children to work as they are getting older, and the costly education expenditure.

There is no significant difference in children's school enrollment and dropout rates between oil palm adopters and non-adopters. However, there is a mixed picture when we disaggregate those variables based on gender. While there is no significant difference between girls in households 
of oil palm adopters and non-adopters, that is not the case for the boys. The boys within households of oil palm adopters have a higher school enrollment and a lower dropout rate than non-adopters. One possible explanation is that non-adopting households require more family labor to work on the farm or off-farm to secure additional income. While the types of work in the oil palm field requires a massive amount of energy that may not be suitable for children, working in rubber plantations requires less power so that young teenagers can perform this work. Boys are more affected by this. In traditional Indonesian society, it is common for boys to help the parents work on the field while girls help them do household chores (Hsin, 2007).

Table 12 Household nutrition and health expenditure by oil palm adoption status (pooled)

\begin{tabular}{|c|c|c|}
\hline Variables & Oil palm adopters & Non-adopters \\
\hline Average farm size (ha) & $\begin{array}{c}6.634 * * * \\
(9.386)\end{array}$ & $\begin{array}{c}3.771 \\
(5.707)\end{array}$ \\
\hline Total household expenditure (million IDR/AE/year) & $\begin{array}{c}15.385 * * * \\
(12.324)\end{array}$ & $\begin{array}{l}11.517 \\
(8.200)\end{array}$ \\
\hline Dietary diversity score (0-9) & $\begin{array}{c}6.937 * * * \\
(1.134)\end{array}$ & $\begin{array}{c}6.585 \\
(1.249)\end{array}$ \\
\hline Calories (kcal/AE/day) & $\begin{array}{c}3375.535 * * * \\
(1606.568)\end{array}$ & $\begin{array}{c}2916.345 \\
(1359.568)\end{array}$ \\
\hline Household food expenditure ('000 IDR/AE/year) & $\begin{array}{c}7866.864 * * * \\
(4376.625)\end{array}$ & $\begin{array}{c}6620.022 \\
(3438.123)\end{array}$ \\
\hline Share of food expenditure (\% of total expenditure) & $\begin{array}{c}0.576 * * * \\
(0.167)\end{array}$ & $\begin{array}{c}0.620 \\
(0.146)\end{array}$ \\
\hline Total health expenditure ('000 IDR/AE/year) & $\begin{array}{c}341.672 \\
(1743.266)\end{array}$ & $\begin{array}{c}248.440 \\
(1385.251)\end{array}$ \\
\hline Hospital expenditure ('000 IDR/AE/year) & $\begin{array}{c}244.994 \\
(1676.197)\end{array}$ & $\begin{array}{c}183.289 \\
(1355.727)\end{array}$ \\
\hline Community health center expenditure ('000 IDR/AE/year) & $\begin{array}{c}13.989 \\
(123.426)\end{array}$ & $\begin{array}{c}9.955 \\
(38.987)\end{array}$ \\
\hline Doctor's practice expenditure ('000 IDR/AE/year) & $\begin{array}{c}20.233 \\
(120.636)\end{array}$ & $\begin{array}{c}20.839 \\
(172.954)\end{array}$ \\
\hline Traditional healer expenditure ('000 IDR/AE/year) & $\begin{array}{c}7.510 \\
(30.107)\end{array}$ & $\begin{array}{c}9.038 \\
(73.419)\end{array}$ \\
\hline Medicine expenditure ('000 IDR/AE/year) & $\begin{array}{c}54.947 * * * \\
(366.800)\end{array}$ & $\begin{array}{c}25.318 \\
(101.333)\end{array}$ \\
\hline Number of observations & 807 & 1,253 \\
\hline
\end{tabular}

Notes: Mean values for the pooled sample, including 2012, 2015, and 2018 survey rounds, are shown with standard deviations in parentheses. Monetary values in 2015 and 2018 were deflated to 2012 values to allow comparison across survey rounds. Total household expenditure, household food expenditure, and health-related expenditure were deflated using the consumer price index, food price index, and medical care price index for Jambi, respectively. In 2012, 1 US\$ was equivalent to IDR 9,670. AE, adult equivalent. Mean differences between adopters and non-adopters were tested for statistical significance. $* * *$ significant at the $1 \%$ level. 
Table 13 Household education by oil palm adoption status (pooled)

\begin{tabular}{lcc}
\hline Education variables & Oil palm adopters & Non-adopters \\
\hline Children's school enrollment (\%) & 0.996 & 0.991 \\
& $(0.054)$ & $(0.089)$ \\
Children's school dropout rates (\%) & 0.118 & 0.140 \\
& $(0.294)$ & $0.320)$ \\
Household education expenditure ('000 IDR/number of school- & $938.831^{* * *}$ & 433.960 \\
aged children/year) & $(3253.433)$ & $(1402.113)$ \\
Number of observations & 529 & 817 \\
& & \\
Girls' school enrollment (\%) & 0.990 & 0.995 \\
& $(0.097)$ & $0.068)$ \\
Girls' school dropout rates (\%) & 0.114 & 0.126 \\
& $(0.305)$ & $(0.318)$ \\
Number of observations & 330 & 482 \\
Boys' school enrollment (\%) & & 0.986 \\
Boys' school dropout rates (\%) & $1.000^{* *}$ & $(0.118)$ \\
& $(0.000)$ & 0.166 \\
Number of observations & $0.123^{*}$ & $(0.357)$ \\
Total out-remittance ('000 IDR/AE/year) & $(0.313)$ & 508 \\
Number of observations & 319 & 767.574 \\
\hline
\end{tabular}

Notes: Mean values for the pooled sample, including 2012, 2015, and 2018 survey rounds, are shown with standard deviations in parentheses. Some number of observations are lower than total samples because only households with school-aged children, girls, or boys are included. Monetary values in 2015 and 2018 were deflated to 2012 values to allow comparison across survey rounds. Household education expenditure and total out-remittance were deflated using the education price index and consumer price index for Jambi, respectively. In 2012, 1 US\$ was equivalent to IDR 9,670. AE, adult equivalent. Mean differences between adopters and non-adopters were tested for statistical significance. $*$, **, $* * *$ significant at the $10 \%, 5 \%$ and $1 \%$ level, respectively.

We look further at expenditure. The household education expenditure and out-remittances of oil palm adopters are significantly higher than the non-adopters (Table 13). These two expenditure variables prove that oil palm adopters invest more in education than their nonadopter counterparts.

Figure 8 shows the housing condition and asset ownership of oil palm adopters and nonadopters. The wall and floor materials of the oil palm adopters and non-adopters are not significantly different. Over $85 \%$ of both groups have a tiled or cemented floor, and almost $70 \%$ have a brick house. Whether or not they cultivate oil palm, the farmers in Jambi can have decent housing. When we look at household assets, the oil palm adopters have significantly higher ownership of some assets such as television, satellite-dish, fridge, washing machine, and four- 
wheel transportation. Unsurprisingly, oil palm adopters have significantly higher electricity expenditure than non-adopters (Table 14). Oil palm adopters also spend significantly higher on communication, which means that they might be more connected to friends and relatives and the latest information. The results are consistent when we comparing the same variables separately based on survey year (Table A. 12 in the Appendix).

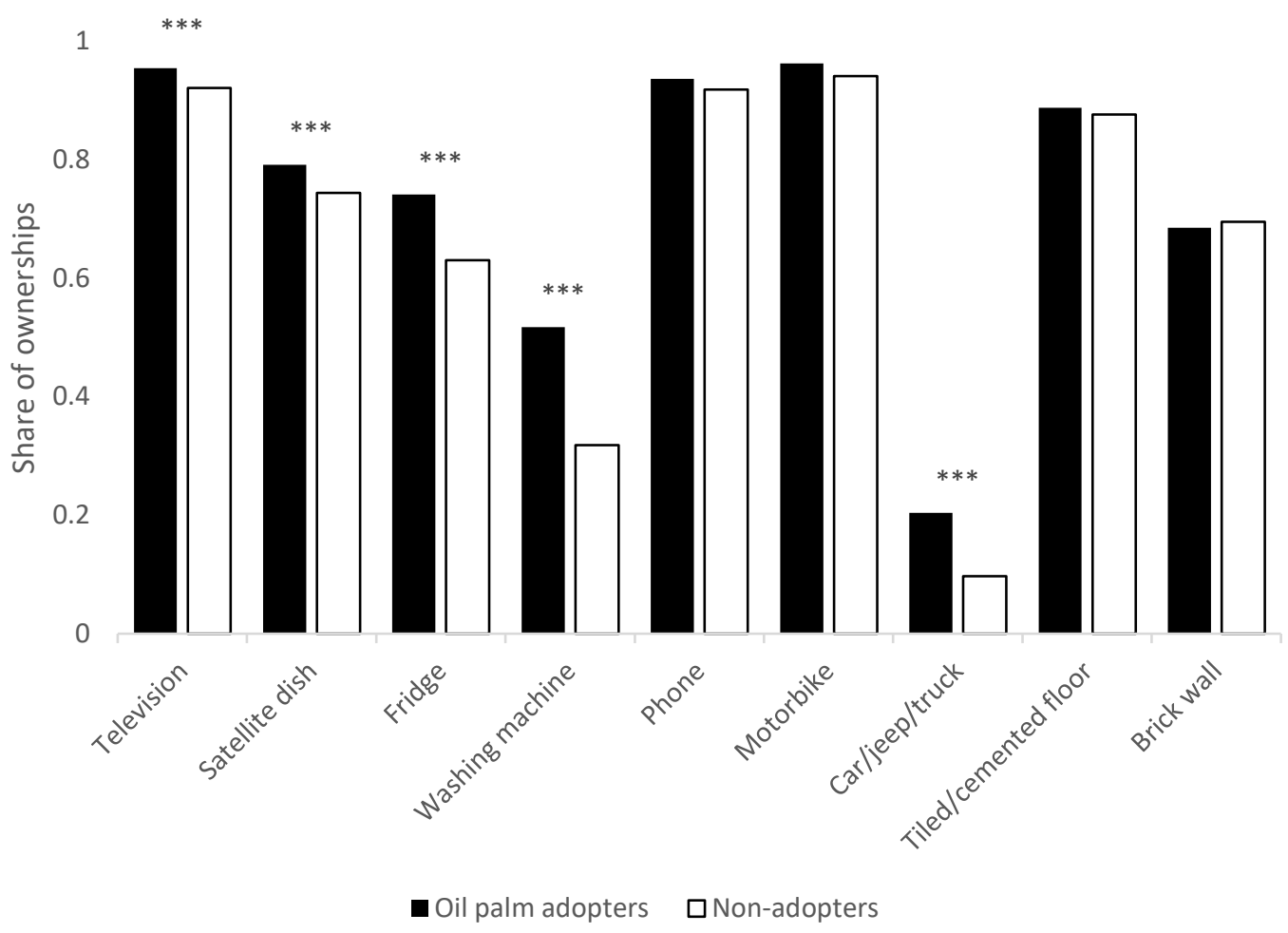

Figure 8 Household asset ownership and housing condition by oil palm adoption status

Notes: *** difference is statistically significant at $1 \%$ level.

Table 14 Household electricity and communication expenditure by oil palm adoption status

\begin{tabular}{lcc}
\hline Variables & Oil palm adopters & Non-adopters \\
\hline Electricity expenditure ('000 IDR/AE/year) & $46.960^{* * * *}$ & 37.661 \\
& $(36.948)$ & $(39.244)$ \\
Communication expenditure ('O00 IDR/AE/year) & $20.153^{* * *}$ & 15.191 \\
& $(25.026)$ & $(22.469)$ \\
Number of observations & 807 & 1,253 \\
\hline
\end{tabular}

Notes: Mean values for the pooled sample, including 2012, 2015, and 2018 survey rounds, are shown with standard deviations in parentheses. Monetary values in 2015 and 2018 were deflated to 2012 values to allow comparison across survey rounds. Electricity expenditure and communication expenditure were deflated using the electricity price index and communication price index for Jambi, respectively. In 2012, 1 US\$ was equivalent to IDR 9,670. $\mathrm{AE}$, adult equivalent. Mean differences between adopters and non-adopters were tested for statistical significance. $* *$, *** significant at $5 \%$ and $1 \%$ level, respectively. 


\subsubsection{Regression results}

We now run regression models to test our hypotheses formally. We hypothesize that oil palm cultivation improves the wellbeing of smallholder farm households. The estimation results from RE and FE panel models are presented in Table 15, Table 16, and Table 17. In general, when estimated using RE, oil palm cultivation has significant positive correlations on the outcome variables, except for some of the health expenditures (Table 16). The FE panel models also show similar effects, although only some are statistically significant. That some effects are significant in the RE but not in the FE models are likely related to the limited variation in oil palm cultivation within households in three different survey years. However, the positive coefficients from RE models together with FE models indicate that there are true effects of oil palm cultivation on the outcome variables.

We present the effects of oil palm cultivation on dietary diversity and calorie consumption in Table 15. When estimated using RE, households that cultivate oil palm consume significantly 0.24 more food groups and $8 \%$ higher calorie than households that do not cultivate oil palm ${ }^{18}$. FE models also show similar results. Hence, oil palm cultivation seems to contribute positively to DDS and calorie consumption.

The next outcome variables that we use are health expenditures. From the descriptive statistics, we learn that the total health expenditure of oil palm adopters is higher than the non-adopters. Yet, it is only significantly higher on medicine expenditure. The results in Table 16 confirm this finding. Oil palm cultivation increases medicine expenditure by $19 \%$ and $54 \%$ when estimated using the RE and the FE model, respectively.

\footnotetext{
${ }^{18}$ The percentage effect of oil palm cultivation dummy variables in log-linear models is estimated by $\left(e^{\widehat{\beta}-\frac{1}{2} \widehat{V A R}(\widehat{\beta})}-1\right) * 100$.
} 
Table 15 Effects of oil palm cultivation on dietary diversity and calories consumption

\begin{tabular}{|c|c|c|c|c|}
\hline \multirow[t]{2}{*}{ Variables } & \multicolumn{2}{|c|}{ DDS } & \multicolumn{2}{|c|}{ Calorie (log, kcal) } \\
\hline & $\mathbf{R E}$ & FE & RE & FE \\
\hline \multirow[t]{2}{*}{ Oil palm adoption (dummy) } & $0.243 * * *$ & 0.181 & $0.081 * * *$ & 0.032 \\
\hline & $(0.061)$ & $(0.122)$ & $(0.019)$ & $(0.040)$ \\
\hline \multirow[t]{2}{*}{ Total land size (ha) } & $0.009 * *$ & 0.001 & $0.005^{* * *}$ & 0.001 \\
\hline & $(0.004)$ & $(0.010)$ & $(0.001)$ & $(0.003)$ \\
\hline \multirow[t]{2}{*}{ Female-headed household (dummy) } & -0.080 & $-0.296^{*}$ & -0.045 & $-0.117 * *$ \\
\hline & $(0.114)$ & $(0.180)$ & $(0.036)$ & $(0.059)$ \\
\hline \multirow[t]{2}{*}{ Household size } & $0.097 * * *$ & $0.121 * * *$ & $-0.062 * * *$ & $-0.059 * * *$ \\
\hline & $(0.018)$ & $(0.028)$ & $(0.006)$ & $(0.009)$ \\
\hline \multirow[t]{2}{*}{ Age of household head (years) } & $-0.007 * *$ & -0.008 & 0.001 & 0.001 \\
\hline & $(0.003)$ & $(0.006)$ & $(0.001)$ & $(0.002)$ \\
\hline \multirow[t]{2}{*}{ Education of household head (years) } & $0.040 * * *$ & -0.009 & $0.009 * * *$ & 0.010 \\
\hline & $(0.009)$ & $(0.019)$ & $(0.003)$ & $(0.006)$ \\
\hline \multirow[t]{2}{*}{ Migrant household (dummy) } & $0.233 * * *$ & & $0.049 * *$ & \\
\hline & $(0.063)$ & & $(0.020)$ & \\
\hline \multirow[t]{2}{*}{ Access to credit (dummy) } & 0.027 & 0.005 & $0.063 * * *$ & $0.080 * * *$ \\
\hline & $(0.059)$ & $(0.077)$ & $(0.019)$ & $(0.025)$ \\
\hline \multirow[t]{2}{*}{ Non-random village (dummy) } & $0.284 * * *$ & & $0.100 * * *$ & \\
\hline & $(0.091)$ & & $(0.028)$ & \\
\hline \multirow[t]{2}{*}{ Distance to market $(\mathrm{km})$} & 0.005 & -0.002 & -0.000 & 0.001 \\
\hline & $(0.004)$ & $(0.007)$ & $(0.001)$ & $(0.002)$ \\
\hline \multirow[t]{2}{*}{ Survey round 2015 (dummy) } & 0.051 & 0.050 & $-0.102 * * *$ & $-0.099 * * *$ \\
\hline & $(0.058)$ & $(0.062)$ & $(0.019)$ & $(0.020)$ \\
\hline \multirow[t]{2}{*}{ Survery round 2018 (dummy) } & $0.140 * *$ & $0.146^{* *}$ & $0.079 * * *$ & $0.089 * * *$ \\
\hline & $(0.060)$ & $(0.071)$ & $(0.020)$ & $(0.023)$ \\
\hline \multirow[t]{2}{*}{ Constant } & $5.974 * * *$ & $6.581 * * *$ & $7.977 * * *$ & $8.024 * * *$ \\
\hline & $(0.190)$ & $(0.381)$ & $(0.060)$ & $(0.125)$ \\
\hline Hausman test, $\chi^{2}$ & 15.88 & & 8.54 & \\
\hline Number of observations & 2,060 & 2,060 & 2,060 & 2,060 \\
\hline
\end{tabular}

Notes: Coefficient estimates of fixed effects panel models are shown with standard errors in parentheses. *, **, *** significant at the $10 \%, 5 \%$, and $1 \%$ level, respectively 
Table 16 Effects of oil palm cultivation on health expenditures (in logarithm IDR)

\begin{tabular}{|c|c|c|c|c|c|c|c|c|c|c|}
\hline \multirow[t]{2}{*}{ Variables } & \multicolumn{2}{|c|}{ Hospital expenditure } & \multicolumn{2}{|c|}{$\begin{array}{l}\text { Community health } \\
\text { center expenditure }\end{array}$} & \multicolumn{2}{|c|}{ Doctor expenditure } & \multicolumn{2}{|c|}{$\begin{array}{c}\text { Traditional healer } \\
\text { expenditure }\end{array}$} & \multicolumn{2}{|c|}{ Medicine expenditure } \\
\hline & RE & FE & RE & FE & RE & FE & RE & FE & RE & FE \\
\hline Oil palm adoption (dummy) & $\begin{array}{c}0.172 \\
(0.105)\end{array}$ & $\begin{array}{c}0.144 \\
(0.234)\end{array}$ & $\begin{array}{l}-0.045 \\
(0.068)\end{array}$ & $\begin{array}{l}-0.194 \\
(0.152)\end{array}$ & $\begin{array}{c}0.047 \\
(0.071)\end{array}$ & $\begin{array}{c}0.265 \\
(0.169)\end{array}$ & $\begin{array}{l}-0.025 \\
(0.056)\end{array}$ & $\begin{array}{l}-0.065 \\
(0.137)\end{array}$ & $\begin{array}{c}0.178 * * \\
(0.082)\end{array}$ & $\begin{array}{c}0.438 * * \\
(0.200)\end{array}$ \\
\hline Total land size (ha) & $\begin{array}{c}0.006 \\
(0.007)\end{array}$ & $\begin{array}{l}-0.006 \\
(0.020)\end{array}$ & $\begin{array}{l}-0.004 \\
(0.004)\end{array}$ & $\begin{array}{c}0.007 \\
(0.013)\end{array}$ & $\begin{array}{c}0.011 * * \\
(0.005)\end{array}$ & $\begin{array}{c}0.008 \\
(0.014)\end{array}$ & $\begin{array}{c}0.004 \\
(0.004)\end{array}$ & $\begin{array}{l}-0.015 \\
(0.012)\end{array}$ & $\begin{array}{c}0.012 * * \\
(0.005)\end{array}$ & $\begin{array}{c}0.015 \\
(0.017)\end{array}$ \\
\hline Female-headed household & $\begin{array}{l}-0.066 \\
(0.199)\end{array}$ & $\begin{array}{l}-0.097 \\
(0.344)\end{array}$ & $\begin{array}{l}-0.100 \\
(0.129)\end{array}$ & $\begin{array}{l}-0.072 \\
(0.224)\end{array}$ & $\begin{array}{c}0.201 \\
(0.137)\end{array}$ & $\begin{array}{c}0.138 \\
(0.250)\end{array}$ & $\begin{array}{c}0.006 \\
(0.108)\end{array}$ & $\begin{array}{l}-0.075 \\
(0.202)\end{array}$ & $\begin{array}{c}-0.268 * \\
(0.158)\end{array}$ & $\begin{array}{l}-0.330 \\
(0.294)\end{array}$ \\
\hline Household size & $\begin{array}{c}0.034 \\
(0.032)\end{array}$ & $\begin{array}{c}0.105 * * \\
(0.053)\end{array}$ & $\begin{array}{c}0.016 \\
(0.020)\end{array}$ & $\begin{array}{l}-0.000 \\
(0.034)\end{array}$ & $\begin{array}{c}0.014 \\
(0.022)\end{array}$ & $\begin{array}{c}0.057 \\
(0.038)\end{array}$ & $\begin{array}{c}-0.011 \\
(0.017)\end{array}$ & $\begin{array}{c}0.039 \\
(0.031)\end{array}$ & $\begin{array}{c}-0.004 \\
(0.025)\end{array}$ & $\begin{array}{c}0.033 \\
(0.045)\end{array}$ \\
\hline Age of household head (years) & $\begin{array}{c}0.003 \\
(0.005)\end{array}$ & $\begin{array}{l}-0.017 \\
(0.012)\end{array}$ & $\begin{array}{c}0.004 \\
(0.003)\end{array}$ & $\begin{array}{c}0.004 \\
(0.008)\end{array}$ & $\begin{array}{c}0.001 \\
(0.003)\end{array}$ & $\begin{array}{l}-0.012 \\
(0.009)\end{array}$ & $\begin{array}{c}-0.006 * * \\
(0.002)\end{array}$ & $\begin{array}{c}0.001 \\
(0.007)\end{array}$ & $\begin{array}{c}0.005 \\
(0.004)\end{array}$ & $\begin{array}{c}0.003 \\
(0.010)\end{array}$ \\
\hline Education of household head & $\begin{array}{c}0.004 \\
(0.015)\end{array}$ & $\begin{array}{c}0.018 \\
(0.036)\end{array}$ & $\begin{array}{l}-0.012 \\
(0.009)\end{array}$ & $\begin{array}{c}0.017 \\
(0.023)\end{array}$ & $\begin{array}{c}0.022 * * \\
(0.010)\end{array}$ & $\begin{array}{c}0.007 \\
(0.026)\end{array}$ & $\begin{array}{c}0.004 \\
(0.008)\end{array}$ & $\begin{array}{c}0.004 \\
(0.021)\end{array}$ & $\begin{array}{c}0.010 \\
(0.011)\end{array}$ & $\begin{array}{c}0.023 \\
(0.031)\end{array}$ \\
\hline Migrant household (dummy) & $\begin{array}{l}0.184 * \\
(0.104)\end{array}$ & & $\begin{array}{l}-0.012 \\
(0.067)\end{array}$ & & $\begin{array}{l}-0.013 \\
(0.070)\end{array}$ & & $\begin{array}{c}0.175^{* * *} * \\
(0.055)\end{array}$ & & $\begin{array}{c}0.064 \\
(0.080)\end{array}$ & \\
\hline Access to credit (dummy) & $\begin{array}{c}0.019 \\
(0.107)\end{array}$ & $\begin{array}{l}-0.140 \\
(0.147)\end{array}$ & $\begin{array}{c}0.098 \\
(0.069)\end{array}$ & $\begin{array}{c}0.248 * * * \\
(0.096)\end{array}$ & $\begin{array}{c}0.098 \\
(0.074)\end{array}$ & $\begin{array}{c}0.150 \\
(0.107)\end{array}$ & $\begin{array}{c}0.052 \\
(0.059)\end{array}$ & $\begin{array}{c}0.017 \\
(0.086)\end{array}$ & $\begin{array}{l}-0.061 \\
(0.086)\end{array}$ & $\begin{array}{l}-0.214 * \\
(0.126)\end{array}$ \\
\hline Non-random village (dummy) & $\begin{array}{l}-0.068 \\
(0.150)\end{array}$ & & $\begin{array}{l}-0.170 * \\
(0.097)\end{array}$ & & $\begin{array}{l}-0.129 \\
(0.101)\end{array}$ & & $\begin{array}{l}-0.004 \\
(0.079)\end{array}$ & & $\begin{array}{c}0.040 \\
(0.116)\end{array}$ & \\
\hline Distance to market $(\mathrm{km})$ & $\begin{array}{l}-0.010 \\
(0.008)\end{array}$ & $\begin{array}{l}-0.007 \\
(0.013)\end{array}$ & $\begin{array}{c}-0.009 * \\
(0.005)\end{array}$ & $\begin{array}{c}-0.024 * * * \\
(0.009)\end{array}$ & $\begin{array}{c}0.003 \\
(0.005)\end{array}$ & $\begin{array}{l}-0.002 \\
(0.010)\end{array}$ & $\begin{array}{c}0.002 \\
(0.004)\end{array}$ & $\begin{array}{l}-0.011 \\
(0.008)\end{array}$ & $\begin{array}{c}0.006 \\
(0.006)\end{array}$ & $\begin{array}{l}-0.015 \\
(0.011)\end{array}$ \\
\hline Survey round 2015 (dummy) & $\begin{array}{l}-0.022 \\
(0.112)\end{array}$ & $\begin{array}{c}0.082 \\
(0.118)\end{array}$ & $\begin{array}{c}-0.456 * * * \\
(0.072)\end{array}$ & $\begin{array}{c}-0.479 * * * \\
(0.077)\end{array}$ & $\begin{array}{c}0.137 * \\
(0.080)\end{array}$ & $\begin{array}{c}0.159 * \\
(0.086)\end{array}$ & $\begin{array}{c}0.397 * * * \\
(0.065)\end{array}$ & $\begin{array}{c}0.387 * * * \\
(0.069)\end{array}$ & $\begin{array}{c}0.338 * * * \\
(0.094)\end{array}$ & $\begin{array}{c}0.383 * * * \\
(0.101)\end{array}$ \\
\hline Survery round 2018 (dummy) & $\begin{array}{l}-0.058 \\
(0.114)\end{array}$ & $\begin{array}{c}0.135 \\
(0.136)\end{array}$ & $\begin{array}{c}-0.541 * * * \\
(0.074)\end{array}$ & $\begin{array}{c}-0.563 * * * \\
(0.088)\end{array}$ & $\begin{array}{c}0.048 \\
(0.082)\end{array}$ & $\begin{array}{c}0.092 \\
(0.098)\end{array}$ & $\begin{array}{c}0.403 * * * \\
(0.066)\end{array}$ & $\begin{array}{c}0.374 * * * \\
(0.079)\end{array}$ & $\begin{array}{c}1.043 * * * \\
(0.096)\end{array}$ & $\begin{array}{c}1.036 * * * \\
(0.116)\end{array}$ \\
\hline Constant & $\begin{array}{c}0.357 \\
(0.326)\end{array}$ & $\begin{array}{c}1.017 \\
(0.730)\end{array}$ & $\begin{array}{c}0.836^{* * *} \\
(0.210)\end{array}$ & $\begin{array}{c}0.765 \\
(0.475)\end{array}$ & $\begin{array}{c}0.108 \\
(0.223)\end{array}$ & $\begin{array}{c}0.579 \\
(0.529)\end{array}$ & $\begin{array}{c}0.294 * \\
(0.176)\end{array}$ & $\begin{array}{c}0.041 \\
(0.427)\end{array}$ & $\begin{array}{c}0.647 * * \\
(0.256)\end{array}$ & $\begin{array}{c}0.566 \\
(0.624)\end{array}$ \\
\hline Hausman test, $\chi^{2}$ & 12.76 & & 12.91 & & 7.90 & & 14.20 & & 14.13 & \\
\hline Number of observations & 2,060 & 2,060 & 2,060 & 2,060 & 2,060 & 2,060 & 2,060 & 2,060 & 2,060 & 2,060 \\
\hline
\end{tabular}

Notes: Coefficient estimates of fixed effects panel models are shown with standard errors in parentheses. *, **, *** significant at the $10 \%, 5 \%$, and $1 \%$ level, respectively. 
Table 17 shows the estimation results for other expenditures. It suggests that oil palm cultivation significantly increases the education expenditure by $41 \%$ when estimated using RE. The positive effect is also observed on the results of the FE model. Meanwhile, oil palm cultivation increases the out-remittance by $51 \%$ and $68 \%$ when estimated using RE and FE, respectively. When we look at electricity expenditure, oil palm cultivation significantly increases this expenditure by $20 \%$ and $22 \%$ when estimated by FE and RE, respectively. When we look at communication that can be associated with connectedness, oil palm also significantly increases this expenditure by $20 \%$ when estimated using the RE model, where the FE model also shows positive effect.

Table 17 Effects of oil palm cultivation on different kind of expenditures (in logarithm IDR)

\begin{tabular}{|c|c|c|c|c|c|c|c|c|}
\hline \multirow[t]{2}{*}{ Variables } & \multicolumn{2}{|c|}{ Education } & \multicolumn{2}{|c|}{ Out-remittances } & \multicolumn{2}{|c|}{ Electricity } & \multicolumn{2}{|c|}{ Communication } \\
\hline & $\mathbf{R E}$ & $\mathbf{F E}$ & RE & $\mathbf{F E}$ & $\mathbf{R E}$ & $\mathbf{F E}$ & $\mathbf{R E}$ & $\mathbf{F E}$ \\
\hline \multirow{2}{*}{$\begin{array}{l}\text { Oil palm cultivation } \\
\text { (dummy) }\end{array}$} & $0.353^{*}$ & 0.574 & $0.415 * * *$ & $0.545^{*}$ & $0.181 * * *$ & $0.200 *$ & $0.180 * * *$ & 0.146 \\
\hline & $(0.195)$ & $(0.436)$ & $(0.150)$ & $(0.315)$ & $(0.057)$ & $(0.110)$ & $(0.066)$ & $(0.131)$ \\
\hline \multirow[t]{2}{*}{ Total land size (ha) } & 0.021 & $-2.6 e-5$ & $0.045 * * *$ & 0.039 & 0.001 & -0.011 & $0.020 * * *$ & 0.017 \\
\hline & $(0.013)$ & $(0.037)$ & $(0.010)$ & $(0.027)$ & $(0.004)$ & $(0.009)$ & $(0.004)$ & $(0.011)$ \\
\hline \multirow{2}{*}{$\begin{array}{l}\text { Female-headed } \\
\text { household (dummy) }\end{array}$} & -0.463 & -0.598 & -0.308 & -0.378 & 0.041 & -0.120 & 0.186 & -0.141 \\
\hline & $(0.411)$ & $(0.766)$ & $(0.282)$ & $(0.463)$ & $(0.105)$ & $(0.162)$ & $(0.123)$ & $(0.193)$ \\
\hline \multirow[t]{2}{*}{ Household size } & 0.005 & 0.004 & $-0.375^{* * *}$ & $-0.461 * * *$ & $-0.113^{* * *}$ & $-0.143 * * *$ & 0.025 & 0.002 \\
\hline & $(0.063)$ & $(0.109)$ & $(0.044)$ & $(0.071)$ & $(0.017)$ & $(0.025)$ & $(0.019)$ & $(0.030)$ \\
\hline \multirow{2}{*}{$\begin{array}{l}\text { Age of household head } \\
\text { (years) }\end{array}$} & 0.011 & -0.020 & 0.007 & -0.004 & 0.000 & -0.001 & -0.003 & -0.004 \\
\hline & $(0.010)$ & $(0.028)$ & $(0.007)$ & $(0.016)$ & $(0.003)$ & $(0.006)$ & $(0.003)$ & $(0.007)$ \\
\hline \multirow{2}{*}{$\begin{array}{l}\text { Education of household } \\
\text { head (years) }\end{array}$} & 0.065 & -0.081 & $0.109 * * *$ & 0.030 & $0.027 * * *$ & 0.000 & $0.062 * * *$ & 0.009 \\
\hline & $(0.028)$ & $(0.073)$ & $(0.021)$ & $(0.049)$ & $(0.008)$ & $(0.017)$ & $(0.009)$ & $(0.020)$ \\
\hline \multirow{2}{*}{$\begin{array}{l}\text { Migrant household } \\
\text { (dummy) }\end{array}$} & -0.062 & & $0.494 * * *$ & & 0.078 & & 0.077 & \\
\hline & $(0.196)$ & & $(0.150)$ & & $(0.059)$ & & $(0.068)$ & \\
\hline \multirow{2}{*}{$\begin{array}{l}\text { Access to credit } \\
\text { (dummy) }\end{array}$} & 0.262 & 0.241 & $0.401 * * *$ & $0.346^{*}$ & 0.044 & -0.079 & $0.335 * * *$ & $0.240 * * *$ \\
\hline & $(0.193)$ & $(0.273)$ & $(0.148)$ & (0.198) & $(0.054)$ & (0.069) & $(0.064)$ & $(0.082)$ \\
\hline \multirow{2}{*}{$\begin{array}{l}\text { Non-random village } \\
\text { (dummy) }\end{array}$} & -0.369 & & -0.173 & & 0.005 & & $-0.174 *$ & \\
\hline & $(0.284)$ & & $(0.218)$ & & $(0.085)$ & & $(0.098)$ & \\
\hline \multirow[t]{2}{*}{ Distance to market $(\mathrm{km})$} & -0.011 & -0.010 & -0.012 & 0.021 & $-0.010 * *$ & 0.004 & $-0.010 * *$ & $-0.019 * *$ \\
\hline & $(0.015)$ & $(0.027)$ & $(0.011)$ & $(0.018)$ & $(0.004)$ & $(0.006)$ & $(0.005)$ & $(0.007)$ \\
\hline \multirow{2}{*}{$\begin{array}{l}\text { Survey round } 2015 \\
\text { (dummy) }\end{array}$} & $0.686 * * *$ & $0.853 * * *$ & -0.185 & -0.191 & $0.160 * * *$ & $0.181 * * *$ & $-0.593 * * *$ & $-0.582 * * *$ \\
\hline & $(0.194)$ & $(0.228)$ & $(0.151)$ & $(0.159)$ & $(0.053)$ & $(0.055)$ & $(0.063)$ & $(0.066)$ \\
\hline \multirow{2}{*}{$\begin{array}{l}\text { Survery round } 2018 \\
\text { (dummy) }\end{array}$} & 0.157 & $0.508 *$ & -0.245 & -0.157 & $0.285 * * *$ & $0.322 * * *$ & 0.056 & 0.080 \\
\hline & $(0.203)$ & $(0.280)$ & $(0.155)$ & $(0.183)$ & $(0.054)$ & $(0.064)$ & $(0.065)$ & $(0.076)$ \\
\hline \multirow[t]{2}{*}{ Constant } & $1.580^{* *}$ & $3.883^{* *}$ & $1.358 * * *$ & $2.893 * * *$ & $3.380 * * *$ & $3.818^{* * *}$ & $1.676^{* * *}$ & $2.359 * * *$ \\
\hline & $(0.622)$ & $(1.544)$ & $(0.464)$ & $(0.982)$ & $(0.175)$ & $(0.343)$ & $(0.205)$ & $(0.409)$ \\
\hline Hausman test, $\chi^{2}$ & 11.36 & & $27.73 * * *$ & & $25.42 * * *$ & & $24.17 * * *$ & \\
\hline Number of observations & 1,346 & 1,346 & 2,060 & 2,060 & 2,060 & 2,060 & 2,060 & 2,060 \\
\hline
\end{tabular}

Notes: Coefficient estimates of fixed effects panel models are shown with standard errors in parentheses. *, **, $* * *$ significant at the $10 \%, 5 \%$, and $1 \%$ level, respectively. Only households with school-aged children are included in education expenditure model. 


\subsection{Conclusion}

Despite its negative implication on the environment and biodiversity, oil palm cultivation by smallholder farmers was shown to increase household income. However, we did not know if this generally better economic condition is also translated to the long-term wellbeing of the smallholder farm households. We intended to answer this question using three rounds of panel data from Indonesia's Jambi province. We used various outcome variables that represent human capital formation, material resources, and social attributes.

Our results show that oil palm cultivation contributes positively to most of the long-term wellbeing indicators that we used. It increases the dietary diversity score, calorie consumption, medicine expenditure, education expenditure, out-remittance, electricity expenditure, and communication expenditure, even statistically significant when estimated using the RE model. That some of the FE model results are not significant is due to the limited variation of oil palm cultivation within the households across the survey years. The findings from this study suggest that oil palm cultivating households invest their income on their wellbeing that potentially benefits them in the long run and increases their living standard.

The findings suggest that it can be worth it for authorities to invest in local and regional infrastructure and facilities such as roads, markets, schools, health care facilities, electricity networks, and entertainment centers. The infrastructures and facilities can help improve the farmers' wellbeing, therefore strengthening human capital and sustainability awareness. There is a higher likelihood that farmers are more willing and able to invest in better environmental practices when they are first already prosperous. However, the positive effects of oil palm cultivation should not be translated as a chance for greater oil palm expansion at the cost of the environment and biodiversity. When creating policies related to oil palm, one should consider both the benefits and disadvantages of oil palm cultivation for a balanced perspective.

Our findings that oil palm cultivation improves the wellbeing of smallholder farm households should not be overgeneralized. We should mention two limitations of our study. First, we conducted our study in Jambi province, where societies have gained an economic advantage from oil palm cultivation and well-established market. The finding might differ in areas with different settings, i.e., provinces with less-developed markets or where oil palm was not shown to improve the societies economically (Santika et al., 2019b). Second, we approach the household's wellbeing objectively. How the variables that we use in this study affect subjective wellbeing, such as being happy and satisfied, cannot be addressed with our data. 
To conclude, further research with longer-term data and conducted in various geographical contexts can enrich our knowledge on this topic. Subjective analysis of wellbeing coupled with an objective approach can also further enhance our understanding of the linkages between oil palm cultivation and smallholder farm households' wellbeing. 


\section{General conclusion}

Oil palm has raised a lot of controversies in the broader public. The crop's major recent expansion in tropical regions is driven by the increasing demand for vegetable oil worldwide used in many products, from food to fuel. Oil palm has been constantly linked to various social and environmental problems and is often portrayed as evil in several respects. However, this is only one side of the picture, as the cultivation of oil palm was also shown to contribute to economic growth and poverty alleviation in producing countries. Environmental and socioeconomic dimensions are equally important in the sustainability debate and illustrate substantial trade-offs. Therefore, studies investigating all possible consequences of oil palm should be considered carefully as inputs when designing policies for sustainable development.

This dissertation has contributed to providing novel empirical evidence to the existing literature of oil palm, focusing on smallholder farmers by looking at various socioeconomic facets. Using panel data from Jambi Province in Sumatra, Indonesia, the three essays in this dissertation analyze the effects of oil palm cultivation on farmers' wellbeing and structural transformation. With good governance, the generally positive impact of oil palm on smallholder farmers might be a blessing in disguise for rural development.

\subsection{Main findings and discussions}

The first essay has analyzed the associations between oil palm cultivation, nutrition, and gender roles. First, we hypothesized that oil palm cultivation is positively associated with household nutrition. Our results confirmed this hypothesis. Oil palm adopting households have higher dietary diversity scores and consume more calories, vitamin A, zinc, and iron than the nonadopters. This association is established as a consequence of rising income that empowers farmers to buy nutritious foods from the market. This is plausible since these farmers already did not grow their own food before they started cultivating oil palm and market infrastructures for food are well established in Jambi. The other aspect that we test in the first essay is the possible change in gender roles. We hypothesized that oil palm cultivation is associated with a lower amount of household labor involved on-farm work than rubber cultivation, leading to higher household participation in off-farm employment. This was shown to be true for male family members but not for female family members. Females work less on oil palm plantations, but we failed to show that this lower on-farm involvement boosts women's participation in off- 
farm activities. This is probably due to the limited job opportunities and society's discouraging perception towards working women in the traditional Indonesian community. However, independent of oil palm cultivation, women's participation in off-farm jobs is positively associated with household nutrition. This is coherent as women often act as primary caregivers in the family that carry out certain activities such as taking care of children, buying groceries, and preparing meals for the whole family. Women's participation in off-farm employment might increase female autonomy, thus improving their decision-making power related to household nutrition.

Structural transformation of agriculture is characterized by the increase of average farm sizes and the reallocation of labor from agriculture to manufacturing and services sectors. In the second essay, we hypothesized that oil palm cultivation increases average farm sizes. This hypothesis was confirmed in the empirical analysis. We also provide evidence that the average size of rubber farms in Jambi has been decreasing in recent years, while the average size of oil palm farms has been increasing. For the second hypothesis, we analyzed whether oil palm cultivation increases household participation in off-farm jobs. We found mixed results for different types of off-farm employment. Oil palm does not significantly affect household participation in employed off-farm activities, possibly due to limited job opportunities in the local setting. However, oil palm increases the likelihood of household involvement in ownbusiness activities, which require capital. Our findings suggest that indeed there is a surplus of labor that is not fully absorbed by non-agricultural sectors. Wealthier households might be able to establish their own non-farm business, but poorer households are probably less able to do so. Moreover, when lucrative off-farm employment is not available, oil palm farmers have a strong incentive to expand their farm by clearing more forestland, in order to make productive use of their surplus labor. This clearly has undesirable environmental consequences.

The third essay provides more evidence on how oil palm might affect farmers' long-term wellbeing. To evaluate wellbeing, we use variables related to human capital, material resources, and social needs, such as nutrition, health expenditures, education, housing, electricity, and communication. We hypothesized that oil palm positively affects our variables of interest. In general, the results demonstrate that oil palm cultivating households have better living standards than the non-adopters, suggesting that the rising income generated from oil palm is invested in items to improve the households' long-term wellbeing. This is an important finding to contribute to a discussion about the consequences of oil palm. If oil palm failed to improve farmers' wellbeing and living standards, cultivating this crop would be doomed as it contributes to 
negative impacts on the environment. However, when farmers' living standards and wellbeing are improved, they may potentially be willing to invest in better environmental practices in the future.

\subsection{Policy implications}

Putting together all findings from the three essays, we found novel shreds of evidence of socioeconomic benefits from oil palm cultivation based on primary data from Sumatra. Yet, we cannot disregard profound negative impacts on the environment. The diverse consequences urge the creation of efficient policies that examine all the sustainability dimensions and tradeoffs carefully. There is certainly no one-size-fits-all policy in the oil palm context. Therefore, policymakers need to critically consider all relevant aspects, including the cultural background, social structure, infrastructure, and geographical location of their policy targets. To balance socioeconomic goals with environment goals, initiatives such as the Roundtable on Sustainable Palm Oil (RSPO) can be enforced and be more inclusive towards smallholder farmers. Considering a large share of smallholder farmers in the oil palm sector, sustainability standards with plausible objectives should target this group as well.

We have shown that oil palm cultivation requires less labor than rubber, resulting in a labor surplus. The creation of more lucrative off-farm employment, especially in the manufacturing and services sectors, in rural areas could absorb this extra labor to stimulate more economic activity that does not rely on merely oil palm. This is also a characteristic of developed regions where the relative importance of the agricultural sector decreases while the manufacturing and services sectors gain in significance. Without enough job opportunities, farmers might be motivated to do further deforestation to expand their farm area. On the other hand, small businesses have been sparked in the villages as a response to limited other employment opportunities. Policymakers might want to support these local businesses, for example, by providing easier access to credit and permits to encourage lucrative economic activity further to flare up in rural areas. Policies promoting women's participation in off-farm sectors should also be boosted to reinforce financial autonomy among women. Women often act as primary caregivers for the family. Hence, increased female financial autonomy might positively influence household wellbeing, such as better nutrition and higher school attendance.

This dissertation demonstrates that the positive contributions of oil palm to smallholder farmers lives are not limited to income gains. We show that oil palm adopters invest their extra income 
in long-term family wellbeing and living standard. Infrastructure and facilities such as roads, markets, schools, hospitals, electricity, and entertainment centers should be constructed and improved so people in rural areas can better access nutritious food, quality education, health care, information, and leisure-time activities. Those are also essential factors in strengthening human capital and sustainability awareness. When farmers are prosperous, they are likely more willing and able to also invest in better environmental practices.

\subsection{Limitations and scope for future research}

In the end, we should mention some limitations of this study and make recommendations for research in the future. We admit that it is quite challenging to provide perfect models for causal inference given several constraints and statistical issues. However, we hope that we have generated the best possible results for this study. Our study uses panel data with three waves spanning over a time period of six years. The data show the increasing number of oil palm adopters and the expansion of oil palm plantations over time. However, the number of farmers who cultivate traditional crops in one wave and then switch to oil palm in a subsequent wave is relatively small, thus limiting data variability over time and statistical efficiency for panel data models with household fixed effects. Studies with data collected over longer periods and more data variation might be useful to evaluate the effects and their stability over time.

The first essay explores the change of gender roles and nutrition status. We should keep in mind that communities in Jambi rely heavily on the market for daily food consumption. It means that markets are sufficiently well established in the village. The same results might not hold in regions with more subsistence-oriented agriculture. Hence, additional research in other socioeconomic settings could be useful to increase external validity of the findings. Meanwhile, for gender roles, our analysis was limited to merely showing women's participation in on-farm and off-farm sectors. Even though the present finding might indicate a sign of women empowerment, we could not confirm this in our study due to data limitation. Yet, gender-related topic in oil palm sector is a critical issue. With better planning and design, future research can include other relevant variables required for gender analysis to address this limitation.

In the second essay, we show the relationship between oil palm cultivation and off-farm employment. Though our analysis is plausible, it can be improved by employing more sensitive variables with more detailed information about off-farm activities. For this study, we use dummy variables of participation in different types of off-farm jobs. But there is still room to 
explore this topic. One idea could be if households are actually involved in lucrative employment. In this study, we categorize off-farm jobs into four categories. We build assumptions from existing studies that agriculture is the least lucrative sector while services and owning a business are the most lucrative ones. In reality, some services and businesses are not lucrative, but we cannot identify this using our data. This could be a compelling research idea to see if oil palm cultivation triggers the creation of lucrative jobs in rural areas. Other relevant aspects that might be interesting to look at are time allocation, type of jobs based on gender, and distance to get lucrative jobs.

In the third essay, we notice drawbacks on some outcome variables that we use. Health expenditures do not perfectly represent the health status of our samples. Though health expenditure describes farmers' ability to cover medical costs, we do not have information on whether the farmers are sick or not. Some farmers may also enjoy the benefit of public insurance. Even though they get health care, they may be exempted from bearing the cost. The same goes for education. Indonesian children should enjoy free primary education in public schools. However, in practice, some education-related fees are still collected in school, whether compulsory or voluntary, legal or illegal. This makes our education expenditure variable in imperfect measure of child education. Therefore, better planning of research may help researchers to get better and more comprehensive education indicators.

Finally, we should be aware that oil palm is cultivated in all main islands of Indonesia, even in some areas of heavily populated Java. However, recent studies about oil palm have only exploited certain areas more than others. Most of them are in Sumatra, where conditions are different than elsewhere and not therefore representative for Indonesia as a whole. Indonesia is a large country in terms of area and population. With more than 17,000 islands and more than 1300 ethnic groups, studies in one specific region may not represent the whole country. Different regions may have different social structures, cultural norms, women empowerment level, farming practices, and infrastructure, along with others. Different results may be observed when oil palm is cultivated in different areas. Therefore, one should carefully consider each study and not generalize to avoid wrong policy conclusions. We encourage other research groups to administer research in other islands, such as Papua, where its unique society and nature have yet to be found in other places. On an island like this, the environmental and economic trade-offs will be tremendous. 


\section{References}

Abram, N. K., Meijaard, E., Wilson, K. A., Davis, J. T., Wells, J. A., Ancrenaz, M., Budiharta, S., Durrant, A., Fakhruzzi, A., Runting, R. K., Gaveau, D., Mengersen, K. 2017. Oil palm-community conflict mapping in Indonesia: A case for better community liaison in planning for development initiatives. Applied Geography 78, 33-44. https://doi.org/10.1016/j.apgeog.2016.10.005

Adamopoulos, T., Restuccia, D. 2014. The size distribution of farms and international productivity differences. American Economic Review 104(6), 1667-1697. https://doi.org/10.1257/aer.104.6.1667

Ahmad, S., Mathai, M. V., \& Parayil, G. 2014. Household electricity access, availability and human well-being: Evidence from India. Energy Policy, 69, 308-315. https://doi.org/10.1016/j.enpol.2014.02.004

Allen, K. A., Ryan, T., Gray, D. L., McInerney, D. M., Waters, L. 2014. Social media use and social connectedness in adolescents: The positives and the potential pitfalls. The Australian Educational and Development Psychologist 31, 18-31. https://doi.org/10.1017/edp.2014.2

Alvarez-Cuadrado, F., Poschke, M. 2011. Structural change out of agriculture: Labor push versus labor pull. American Economic Journal: Macroeconomics 3(3), 127-158. https://doi.org/10.1257/mac.3.3.127

Anderman, T. L., Remans, R., Wood, S. A., DeRosa, K., DeFries, R. S. 2014. Synergies and tradeoffs between cash crop production and food security: A case study in rural Ghana. Food Security 6, 541-554. https://doi.org/10.1007/s12571-014-0360-6

Athukorala, W., Wilson, C., Robinson, T. 2012. Determinants of health costs due to farmers' exposure to pesticides: An empirical analysis. Journal of Agricultural Economics 63, 158-174. https://doi.org/10.1111/j.1477-9552.2011.00326.x

Bazzi, S., Gaduh, A., Rothenberg, A. D., Wong, M. 2016. Skill transferability, migration, and development: Evidence from population resettlement in Indonesia. American Economic Review 106(9), 2658-2698. https://doi.org/10.1257/aer.20141781

Berger, J., Blanchard, G., Ponce, M. C., Chamnan, C., Chea, M., Dijkhuizen, M., Doak, C., Doets, E., Fahmida, U., Ferguson, E., Hulshof, P., Kameli, Y., Kuong, K., Akkhavong, 
K., Sengchanh, K., Le, B. M., Tran, T. L., Muslimatun, S., Roos, N., Sophonneary, P., Wieringa, F., Wasantwisut, E., Winichagoon, P., SMILING Consortium Group. 2013. The SMILING project: a North-South-South collaborative action to prevent micronutrient deficiencies in women and young children in Southeast Asia. Food and Nutrition Bulletin 34, 133-139. https://doi.org/10.1177/15648265130342S115

Berger, T., Frey, C. B. 2016. Structural transformation in the OECD. Digitalisation, deindustralisation and the future of work. OECD Social, Employment and Migration Working Papers 193. Organisation for Economic Cooperation and Development, Paris. https://doi.org/10.1787/5jlr068802f7-en

Black, R. E., Victora, C. G., Walker, S. P., Bhutta, Z. A., Christian, P., De Onis, M., Ezzati, M., Grantham-Mcgregor, S., Katz, J., Martorell, R., Uauy, R. 2013. Maternal and child undernutrition and overweight in low-income and middle-income countries. Lancet 382, 427-451. https://doi.org/10.1016/S0140-6736(13)60937-X

Bleakley, H. 2010. Health, human capital, and development. Annual Review of Economics 2, 283-310. https://doi.org/10.1146/annurev.economics.102308.124436

Bokusheva, R., Kimura, S. 2016. Cross-country comparison of farm Size distribution. OECD Food, Agriculture and Fisheries Papers 94. Organisation for Economic Cooperation and Development, Paris. http://doi.org/10.1787/5jlv81sclr35-en

Bou Dib, J., Alamsyah, Z., Qaim, M. 2018a. Land-use change and income inequality in rural Indonesia. Forest Policy and Economics 94, 55-66. https://doi.org/10.1016/j.forpol.2018.06.010

Bou Dib, J., Krishna, V. V., Alamsyah, Z., Qaim, M. 2018b. Land-use change and livelihoods of non-farm households: The role of income from employment in oil palm and rubber in rural Indonesia. Land Use Policy 76, 828-838. https://doi.org/10.1016/j.landusepol.2018.03.020

Bratt, R. G. 2002. Housing and family well-being. Housing Studies 17, 13-26. https://doi.org/10.1080/02673030120105857

de Brauw, A., Mueller, V., Lee, H. L. 2014. The role of rural-urban migration in the structural transformation of Sub-Saharan Africa. World Development 63, 33-42. http://doi.org/10.1016/j.worlddev.2013.10.013

Bustos, P., Caprettini, B., Ponticelli, J. 2016. Agricultural productivity and structural 
transformation: Evidence from Brazil. American Economic Review 106(6), 1320-1365. https://doi.org/10.1257/aer.20131061

Byerlee, D., Falcon, W. P., Naylor, R. L. 2017. The Tropical Oil Crop Revolution: Food, Feed, Fuel, and Forests. Oxford University Press, Oxford.

Carrere, R. 2013. Oil palm in Africa: Past, present, and future scenarios.WRM series on tree plantations 15. Montevideo, Uruguay.

Cassman, K. G., Liska, A. J. 2007. Food and fuel for all: Realistic or foolish? Biofuels, Bioprod. Biorefining 1, 18-23. https://doi.org/10.1002/bbb.3

Chiputwa, B., Qaim, M. 2016. Sustainability Standards, Gender, and Nutrition among Smallholder Farmers in Uganda. Journal of Development Studies 52, 1241-1257. https://doi.org/10.1080/00220388.2016.1156090

Choiruzzad, S. A. 2019. Save palm oil, save the nation: Palm oil companies and the shaping of Indonesia's national interest. Asian Politics and Policy 11, 8-26. https://doi.org/10.1111/aspp.12431

Chrisendo, D., Krishna, V. V., Siregar, H., Qaim, M. 2020. Land-use change, nutrition, and gender roles in Indonesian farm households. Forest Policy and Economics 118, 102245. https://doi.org/10.1016/j.forpol.2020.102245

Chrisendo, D., Siregar, H., Qaim, M. in press. Oil palm and structural transformation of agriculture in Indonesia. Agricultural Economics.

Clough, Y., Krishna, V. V., Corre, M.D., Darras, K., Denmead, L. H., Meijide, A., Moser, S., Musshoff, O., Steinebach, S., Veldkamp, E., Allen, K., Barnes, A. D., Breidenbach, N., Brose, U., Buchori, D., Daniel, R., Finkeldey, R., Harahap, I., Hertel, D., Holtkamp, A. M., Hörandl, E., Irawan, B., Jaya, I. N. S., Jochum, M., Klarner, B., Knohl, A., Kotowska, M. M., Krashevska, V., Kreft, H., Kurniawan, S., Leuschner, C., Maraun, M., Melati, D. N., Opfermann, N., Pérez-Cruzado, C., Prabowo, W. E., Rembold, K., Rizali, A., Rubiana, R., Schneider, D., Tjitrosoedirdjo, S. S., Tjoa, A., Tscharntke, T., Scheu, S. 2016. Land-use choices follow profitability at the expense of ecological functions in Indonesian smallholder landscapes. Nature Communications 7. https://doi.org/10.1038/ncomms 13137

Coley, R. L., Leventhal, T., Lynch, A. D. Kull, M. 2013. Relations between housing characteristics and the well-being of low-income children and adolescents. 
Developmental Psychology 49, 1775-1789. https://doi.org/10.1037/a0031033

Corley, R. H. V., Tinker, P. B. 2016. The oil palm (5th ed.). Wiley Blackwell, Chichester.

Cramb, R., Curry, G. N. 2012. Oil palm and rural livelihoods in the Asia-Pacific region: An overview. Asia Pacific Viewpoint, 53, 223-239. https://doi.org/10.1111/j.14678373.2012.01495.x

Darras, K. F. A., Corre, M. D., Formaglio, G., Tjoa, A., Potapov, A., Brambach, F., Sibhatu, K. T., Grass, I., Angulo Rubiano, A., Buchori, D., Drescher, J., Fardiansah, R., Hölscher, D., Irawan, B., Kneib, T., Krashevska, V., Krause, A., Kreft, H., Li, K., Maraun, M., Polle, A., Ryadin, A. A., Rembold, K., Stiegler, C., Scheu, S., Tarigan, S., Valdes-Uribe, A., Yadi, S., Tscharntke, T., Veldkamp, E. 2019. Reducing fertilizer and avoiding herbicides in oil palm plantations-Ecological and economic valuations. Frontiers in Forests and Global Change 2(65). https://doi.org/10.3389/ffgc.2019.00065

Deaton, A., 1997. The analysis of household surveys: A microeconometric approach to development policy. Johns Hopkins University Press, Baltimore, MD.

Debela, B. L., Gehrke, E., Qaim, M. 2020. Links between maternal employment and child nutrition in rural Tanzania. American Journal of Agricultural Economics. https://doi.org/10.1111/ajae.12113

Development Initiatives. 2018. Global nutrition report. Development Initiatives, Bristol, UK.

Dinas Kesehatan Jambi, 2016. Profil kesehatan provinsi Jambi 2015. Dinas Kesehatan Provinsi Jambi, Jambi.

Dodge, R., Daly, A., Huyton, J., Sanders, L. 2012. The challenge of defining wellbeing. International Journal of Wellbeing 2, 222-235. https://doi.org/10.5502/ijw.v2i3.4

Dradjat, B. 2012. Structure, roles, challenges, and opportunities of the oil palm industry in Indonesia: The significance of oil palm smallholders. Oil Palm Bulletin 64, 1-22.

Drescher, J., Rembold, K., Allen, K., Beckschäfer, P., Buchori, D., Clough, Y., Faust, H., Fauzi, A. M., Gunawan, D., Hertel, D., Irawan, B., Jaya, I. N. S., Klarner, B., Kleinn, C., Knohl, A., Kotowska, M. M., Krashevska, V., Krishna, V., Leuschner, C., Lorenz, W., Meijide, A., Melati, D., Nomura, M., Pérez-Cruzado, C., Qaim, M., Siregar, I. Z., Steinebach, S., Tjoa, A., Tscharntke, T., Wick, B., Wiegand, K., Kreft, H., Scheu, S. 2016. Ecological and socio-economic functions across tropical land use systems after 
rainforest conversion. Philosophical Transactions of the Royal Society B 371, 20150275. https://doi.org/10.1098/rstb.2015.0275

Duarte, M., Restuccia, D. 2010. The role of the structural transformation in aggregate productivity. Quarterly Journal of Economics 125(1), 129-173. https://doi.org/10.1162/qjec.2010.125.1.129

Eastwood, R., Lipton, M., Newell, A. 2010. Farm size. Hanbook of Agricultural Economics 4, 3323-3397. https://doi.org/10.1016/S1574-0072(09)04065-1

Edwards, R. B. 2019a. Spillovers from agricultural processing. Working Paper. Dartmouth College Hanover.

Edwards R. B. 2019b. Export agriculture and rural poverty: Evidence from Indonesian palm oil. Working Paper. Dartmouth College Hanover.

Elmhirst, R., Siscawati, M., Basnett, B.S., Ekowati, D. 2017. Gender and generation in engagements with oil palm in East Kalimantan, Indonesia: insights from feminist political ecology. Journal of Peasant Studies 44, 1137-1159.

https://doi.org/10.1080/03066150.2017.1337002

Euler, M., Krishna, V., Schwarze, S., Siregar, H., Qaim, M. 2017. Oil palm adoption, household welfare, and nutrition among smallholder farmers in Indonesia. World Development 93, 219-235. https://doi.org/10.1016/j.worlddev.2016.12.019

Euler, M., Schwarze, S., Siregar, H., Qaim, M. 2016. Oil palm expansion among smallholder farmers in Sumatra, Indonesia. Journal of Agricultural Economics 67, 658-676. https://doi.org/10.1111/1477-9552.12163

FAO. 2011. Guidelines for measuring household and individual dietary diversity. Food and Agriculture Organization, Rome.

FAO. 2020. FAOSTAT statistical database. Retrieved from: http://www.fao.org/faostat/en/\#data/ QC/visualize.

Fearnside, P. M. 1997. Transmigration in Indonesia: Lessons from its environmental and social impacts. Environmental Management 21, 553-570.

Feintrenie, L., Chong, W. K., Levang, P. 2010. Why do farmers prefer oil palm? Lessons learnt from Bungo District, Indonesia. Small-scale Forestry 9, 379-396. https://doi.org/10.1007/s11842-010-9122-2 
Feintrenie, L., Levang, P. 2009. Sumatra's rubber agroforests: Advent, rise and fall of a sustainable cropping system. Small-scale Forestry 8(3), 323-335. https://doi.org/10.1007/s11842-009-9086-2

Fongar, A., Gödecke, T., Aseta, A. Qaim, M. 2019. How well do different dietary and nutrition assessment tools match? Insights from rural Kenya. Public Health Nutrition 22, 391-403. https://doi.org/10.1017/S1368980018002756

Frankenberg, E., Thomas, D. 2017. Human capital and shocks: Evidence on education, health, and nutrition, NBER Working Paper Series. Cambridge, MA. https://doi.org/doi.org/10.3386/w23347

Gatto, M., Wollni, M., Asnawi, R., Qaim, M. 2017. Oil palm boom, contract farming, and rural economic development: village-level evidence from Indonesia. World Development 95, 127-140. https://doi.org/10.1016/j.worlddev.2017.02.013

Gatto, M., Wollni, M., Qaim, M. 2015. Oil palm boom and land-use dynamics in Indonesia: The role of policies and socio-economic factors. Land Use Policy 46, 292-303. https://doi.org/10.1016/j.landusepol.2015.03.001

Gilbert, C. L., Morgan, C. W. 2010. Food price volatility. Philosophical Transactions of the Royal Society B 365, 3023-3034. https://doi.org/10.1098/rstb.2010.0139

Grass, I., Kubitza, C., Krishna, V. V., Corre, M. D., Mußhoff, O., Pütz, P., Drescher, J., Rembold, K., Ariyanti, E. S., Barnes, A. D., Brinkmann, N., Brose, U., Brümmer, B., Buchori, D., Daniel, R., Darras, K. F. A., Faust, H., Fehrmann, L., Hein, J., Hennings, N., Hidayat, P., Hölscher, D., Jochum, M., Knohl, A., Kotowska, M. M., Krashevska, V., Kreft, H., Leuschner, C., Lobite, N. J. S., Panjaitan, R., Polle, A., Potapov, A. M., Purnama, E., Qaim, M., Röll, A., Scheu, S., Schneider, D., Tjoa, A., Tscharntke, T., Veldkamp, E., Wollni, M. 2020. Trade-offs between multifunctionality and profit in tropical smallholder landscapes. Nature Communications 11, 1186. https://doi.org/10.1038/s41467-020-15013-5

Greene, W. H. 2012. Econometric Analysis (7th ed.). Prentice Hall, Upper Saddle River, NJ.

Ha, W., Mendoza, R. 2010. The intended and unintended consequences of social protection on school dropout in post-crisis Indonesia. Journal of International Development 22, 1115-1133. https://doi.org/10.1002/jid.1750

Habibie, W. L., Hardjosoekarto, S., Kasim, A. 2017. Health reform in Indonesia towards 
sustainable development growth (Case study on BPJS Kesehatan, health insurance in Indonesia). Review of Integrative Business and Economics Research 6, 375-383.

Hadi, U., van den Broek, P., Kolopaking, E. P., Zairina, N., Gardjito, W., Gyssens, I. C. 2010. Cross-sectional study of availability and pharmaceutical quality of antibiotics requested with or without prescription (Over The Counter) in Surabaya, Indonesia. BMC Infectious Diseases 10, 203. https://doi.org/10.1186/1471-2334-10-20

de Haen, H., Klasen, S., Qaim, M. 2011. What do we really know? Metrics for food insecurity and undernutrition. Food Policy 36, 760-769. https://doi.org/10.1016/j.foodpol.2011.08.003

Herrendorf, B., Rogerson, R., \& Valentinyi, Á. 2014. Growth and structural transformation. Handbook of Economic Growth 2, 855-941. https://doi.org/10.1016/B978-0-444-535405.00006-9

Hidayat, N. K., Offermans, A., Glasbergen, P. 2018. Sustainable palm oil as a public responsibility? On the governance capacity of Indonesian Standard for Sustainable Palm Oil (ISPO). Agriculture and Human Values 35, 223-242. https://doi.org/10.1007/s10460-017-9816-6

Hsin, A. 2007. Children's time use: Labor divisions and schooling in Indonesia. Journal of Marriage and Family 69, 1297-1306. https://doi.org/10.1111/j.1741-3737.2007.00448.x

Ibnu, M., Offermans, A., Glasbergen, P. 2018. Certification and farmer organisation: Indonesian smallholder perceptions of benefits. Bulletin of Indonesian Economic Studies 54, 387-415. https://doi.org/10.1080/00074918.2018.1506093

ILO. 2019. Advancing worker's rights in Indonesia's palm oil sector project. Retrieved from https://www.ilo.org/wcmsp5/groups/public/---asia/---ro-bangkok/---ilojakarta/documents/genericdocument/wcms_734058.pdf.

IMF. 2020. Primary commodity price. Retrieved from https://data.imf.org/?sk=471DDDF8D8A7-499A-81BA-5B332C01F8B9

Indonesian Bureau of Statistics. 2019. Luas tanaman perkebunan menurut propinsi dan jenis tanaman, Indonesia. Retrieved from https://www.bps.go.id/dynamictable/2015/09/04/838/luas-tanaman-perkebunan-menurutpropinsi-dan-jenis-tanaman-indonesia-000-ha-2011-2018-.html 
Jayne, T. S., Chamberlin, J., Traub, L., Sitko, N., Muyanga, M., Yeboah, F. K. Anseeuw, W., Chapoto, A., Wineman, A., Nkonde, C., Kachule, R. 2016. Africa's changing farm size distribution patterns: The rise of medium-scale farms. Agricultural Economics 47, 197214. https://doi.org/10.1111/agec. 12308

Johnston, D., Stevano, S., Malapit, H. J., Hull, E., Kadiyala, S. 2018. Review: Time use as an explanation for the agri-nutrition disconnect: Evidence from rural areas in low and middle-income country. Food Policy 76, 8-18. https://doi.org/10.1016/j.foodpol.2017.12.011

Jose, P. E., Ryan, N., Pryor, J. 2012. Does social connectedness promote a greater sense of well-being in adolescence over time? Journal of Research on Adolescence 22, 235-251. https://doi.org/10.1111/j.1532-7795.2012.00783.x

Ke, X., Saksena, P., Holly, A. 2011. The determinants of health expenditure: A country-level panel data analysis, Working Paper of the Results for Development Institute. Washington, DC.

Kreager, P. 2006. Migration, social structure and old-age support networks: A comparison of three Indonesian communities. Ageing and Society 26(1), 37-60. https://doi.org/10.1017/S0144686X05004411

Krishna, V., Euler, M., Siregar, H., Qaim, M. 2017a. Differential livelihood impacts of oil palm expansion in Indonesia. Agricultural Economics 48, 639-653. https://doi.org/10.1111/agec.12363

Krishna, V., Kubitza, C., Pascual, U., Qaim, M. 2017b. Land markets, property rights, and deforestation: Insights from Indonesia. World Development 99, 335-349. https://doi.org/10.1016/j.worlddev.2017.05.018

Kubitza, C., Krishna, V. V. 2020. Instrumental variables and the claim of causality: Evidence from impact studies in maize systems. Global Food Security 26, 100383, https://doi.org/10.1016/j.gfs.2020.100383

Kubitza, C., Krishna, V.V., Alamsyah, Z., Qaim, M. 2018a. The economics behind an ecological crisis: Livelihood effects of oil palm expansion in Sumatra, Indonesia. Human Ecology 46, 107-116. https://doi.org/10.1007/s10745-017-9965-7

Kubitza, C., Krishna, V.V., Urban, K., Alamsyah, Z., Qaim, M. 2018b. Land property rights, agricultural intensification, and deforestation in Indonesia. Ecological Economics 147, 
312-321. https://doi.org/10.1016/j.ecolecon.2018.01.021

Larson, D. F. 1996. Indonesia’s palm oil subsector. Policy Research Working Paper 1654. World Bank, Washington, DC.

Lecoutere, E., Jassogne, L. 2019. Fairness and efficiency in smallholder farming: The relation with intrahousehold decision-making. Journal of Development Studies 55, 57-82. https://doi.org/10.1080/00220388.2017.1400014

Levang, P., Riva, W. F., Orth, M. G. 2016. Oil palm plantations and conflict in Indonesia: evidence from West Kalimantan, in: Cramb, R., McCarthy, J.F. (Eds.), The Oil Palm Complex Smallhoders, Agribusiness and the State in Indonesia and Malaysia. NUS Press, Singapore, pp. 283-300.

Li, T. M. 2009. Exit from agriculture: A step forward or a step backward for the rural poor? Journal of Peasant Studies 36(3), 629-636. https://doi.org/10.1080/03066150903142998

Li, T. M. 2015. Social impacts of oil palm in Indonesia: A gendered perspective from West Kalimantan. CIFOR Occasional Paper 124. CIFOR, Bogor. https://doi.org/10.17528/cifor/005579

Lowder, S. K., Skoet, J., Raney, T. 2016. The number, size, and distribution of farms, smallholder farms, and family farms worldwide. World Development 87, 16-29. https://doi.org/10.1016/j.worlddev.2015.10.041

Lund, P., Price, R. 1998. The measurement of average farm size. Journal of Agricultural Economics 49, 100-110. https://doi.org/10.1111/j.1477-9552.1998.tb01254.x

MacDonald, J. M., Korb, P., Hoppe, R. A. 2013. Farm size and the organization of U.S. crop farming. Economic Research Report 152. US Department of Agriculture, Washington, DC.

Majlesi, K. 2016. Labor market opportunities and women's decision making power within households. Journal of Development Economics 119, 34-47.

Malapit, H. J. L., Quisumbing, A. R. 2015. What dimensions of women's empowerment in agriculture matter for nutrition in Ghana? Food Policy 52, 54-63.

https://doi.org/10.1016/j.foodpol.2015.02.003

Mariyono, J. 2015. Green revolution- and wetland-linked technological change of rice agriculture in Indonesia. Management of Environmental Quality: An International 
Journal 26(5), 683-700. https://doi.org/10.1108/MEQ-07-2014-0104

Mariyono, J. 2019a. Micro-credit as catalyst for improving rural livelihoods through agribusiness sector in Indonesia. Journal of Entrepreneurship in Emerging Economies 11(1), 98-121. https://doi.org/10.1108/JEEE-06-2017-0046

Mariyono, J. 2019b. Microcredit and technology adoption: Sustained pathways to improve farmers' prosperity in Indonesia. Agricultural Finance Review 79(1), 85-106. https://doi.org/10.1108/AFR-05-2017-0033

Mariyono, J., Kompas, T., Grafton, R. Q. 2010. Shifting from green revolution to environmentally sound policies: Technological change in Indonesian rice agriculture. Journal of the Asia Pacific Economy 15(2), 128-147. https://doi.org/10.1080/13547861003700109

Marlier, M. E., DeFries, R. S., Kim, P. S., Koplitz, S. N., Jacob, D. J., Mickley, L. J., Myers, S. S. 2015. Fire emissions and regional air quality impacts from fires in oil palm, timber, and logging concessions in Indonesia. Environmental Research Letters 10, 085005. https://doi.org/10.1088/1748-9326/10/8/085005

Martinez, A., Western, M., Haynes, M., Tomaszewski, W., Macarayan, E. 2014. Multiple job holding and income mobility in Indonesia. Research in Social Stratification and Mobility 37, 91-104. http://doi.org/10.1016/j.rssm.2013.09.008

Martorell, R. 2017. Improved nutrition in the first 1000 days and adult human capital and health. American Journal of Human Biology 29, 1-12. https://doi.org/https://doi. org/10.1002/ajhb.22952

Martorell, R., Melgar, P., Maluccio, J. A., Stein, A. D., Rivera, J. A. 2010. The nutrition intervention improved adult human capital and economic productivity. Journal of Nutrition 140, 411-414. https://doi.org/10.3945/jn.109.114504

Mazur, A. 2011. Does increasing energy or electricity consumption improve quality of life in industrial nations? Energy Policy 39, 2568-2572. https://doi.org/10.1016/j.enpol.2011.02.024

McCarthy, J. F., Gillespie, P., Zen, Z. 2012. Swimming upstream: Local Indonesian production networks in "globalized" palm oil production. World Development 40, 555569. https://doi.org/10.1016/j.worlddev.2011.07.012 
McCarthy, J. F., Zen, Z. 2016. Agribusiness, agrarian change, and the fate of oil palm smallholders in Jambi. In Cramb, R. \& McCarthy, J. F. eds. The Oil Palm Complex Smallhoders, Agribusiness and the State in Indonesia and Malaysia, 109-154. NUS Press, Singapore.

Meijaard, E., Brooks, T. M., Carlson, K. M., Slade, E. M., Garcia-Ulloa, J., Gaveau, D. L. A., Lee, J. S. H., Santika, T., Juffe-Bignoli, D., Struebig, M. J., Wich, S. A., Ancrenaz, M., Koh, L. P., Zamira, N., Abrams, J. F., Prins, H. H. T., Sendashonga, C. N., Murdiyarso, D., Furumo, P. R., Macfarlane, N., Hoffmann, R., Persio, M., Descals, A., Szantoi, Z., Sheil, D. 2020. The environmental impacts of palm oil in context. Nature Plants 6, 14181426. https://doi.org/10.1038/s41477-020-00813-w

Meijaard, E., Sheil, D. 2019. The moral minefield of ethical oil palm and sustainable development. Frontiers in Forests and Global Change 2, 22. https://doi.org/10.3389/ffgc.2019.00022

Merten, J., Stiegler, C., Hennings, N., Purnama, E. S., Röll, A., Agusta, H., Dippold, M. A., Fehrmann, L., Gunawan, D., Hölscher, D., Knohl, A., Kückes, J., Otten F., Zemp, D. C., Faust, H. 2020. Flooding and land use change in Jambi Province, Sumatra: Integrating local knowledge and scientific inquiry. Ecology and Society 25(3), 14. https://doi.org/10.5751/ES-11678-250314

Ministry of Agriculture Indonesia, 2016. Tree crop estate statistics of Indonesia: Palm oil 2015-2017. Ministry of Agriculture Indonesia, Jakarta.

Ministry of Agriculture Indonesia. 2019a. Tree crop estate statistics of Indonesia 2018-2020: Palm oil. Retrieved from https://drive.google.com/file/d/1FVxpBNihnuB3ayAALBiFtsBShIUxMTD/view

Ministry of Agriculture Indonesia. 2019b. Tree crop estate statistics of Indonesia 2018-2020: Rubber. Retrieved from https://drive.google.com/file/d/1YOOvbAPB8EnAkgo40xJyo40JwAukg0GQ/view

Murthy, V. N. R., Okunade, A. A. 2009. The core determinants of health expenditure in the African context: Some econometric evidence for policy. Health Policy 91, 57-62. https://doi.org/https://doi.org/10.1016/j.healthpol.2008.10.001

Niehof, A., Gartaula, H. N., Quetulio-Navarra, M. 2018. Diversity and change in food wellbeing: Cases from Southeast Asia and Nepal. Wageningen Academic Publishers, 
Wageningen, https://doi.org/10.3920/978-90-8686-864-3

O'Shaughnessy, K. 2009. Gender, state, and social power in contemporary Indonesia: Divorce and marriage law. Routledge, New York.

Obidzinski, K., Dermawan, A., Hadianto, A. 2014. Oil palm plantation investments in Indonesia's forest frontiers: Limited economic multipliers and uncertain benefits for local communities. Environment, Development and Sustainability 16, 1177-1196. https://doi.org/10.1007/s10668-014-9519-8

Obidzinski, K., Andriani, R., Komarudin, H., Andrianto, A. 2012. Environmental and social impacts of oil palm plantations and their implications for biofuel production in Indonesia. Ecology and Society 17(1), 25. https://doi.org/10.5751/ES-04775-170125

Pangaribowo, E. H., Tsegai, D., Sukamdi. 2019. Women's bargaining power and household expenditure in Indonesia: The role of gender-differentiated assets and social capital. GeoJournal 84, 939-960. https://doi.org/10.1007/s10708-018-9901-4

Parinduri, R. A. 2014. Do children spend too much time in schools? Evidence from a longer school year in Indonesia. Economics of Education Review 41, 89-104. https://doi.org/10.1016/j.econedurev.2014.05.001

Park, C. M. Y., White, B., Julia. 2015. We are not all the same: taking gender seriously in food sovereignty discourse. Third World Quarterly 36, 584-599. https://doi.org/10.1080/01436597.2015.1002988

Parmanto, B., Paramita, M. V., Sugiantara, W., Pramana, G., Scotch, M., Burke, D. S. 2008. Spatial and multidimensional visualization of Indonesia's village health statistics. International Journal of Health Geographics 7, 1-14. https://doi.org/10.1186/1476-072X7-30

Pearson, A. L., Mack, E., Namanya, J. 2017. Mobile phones and mental well-being: Initial evidence suggesting the importance of staying connected to family in rural, remote communities in Uganda. PLoS One 12, e0169819. https://doi.org/10.1371/journal.pone.0169819

Pingali, P. 2007. Agricultural mechanization: Adoption patterns and economic impact. Handbook of Agricultural Economics 3, 2779-2805. https://doi.org/10.1016/S15740072(06)03054-4 
Pratiwi, A., Suzuki, A. 2017. Effects of farmers' social networks on knowledge acquisition: Lessons from agricultural training in rural Indonesia. Journal of Economic Structtures 6, 8. https://doi.org/10.1186/s40008-017-0069-8

Purnomo, H., Okarda, B., Dewayani, A. A., Ali, M., Achdiawan, R., Kartodihardjo, H., Pacheco, P., Juniwaty, K. S. 2018. Reducing forest and land fires through good palm oil value chain governance. Forest Policy and Economics 91 94-106. https://doi.org/10.1016/j.forpol.2017.12.014

Qaim, M., Sibhatu, K. T., Siregar, H., Grass, I. 2020. Environmental, economic, and social consequences of the oil palm boom. Annual Review of Resource Economics 12, 321-344 https://doi.org/10.1146/annurev-resource-110119-024922.

Quetulio-Navarra, M., Frunt, E., Niehof, A. 2018. The role of social capital and institutions in food security and wellbeing of children under five for resettled households in Central Java, Indonesia. In Niehof, A., Gartaula, H. N., \& Quetulio-Navarra, M. eds. Diversity and change in food wellbeing, 115-136. Wageningen Academic Publishers, Wageningen.

Rist, L., Feintrenie, L., Levang, P. 2010. The livelihood impacts of oil palm: Smallholders in Indonesia. Biodiversity and Conservation 19, 1009-1024. https://doi.org/10.1007/s10531-010-9815-z

Ross, D. A., Hinton, R., Melles-Brewer, M., Engel, D., Zeck, W., Fagan, L., Herat, J., Phaladi, G., Imbago-Jácome, D., Anyona, P., Sanchez, A., Damji, N., Terki, F., Baltag, V., Patton, G., Silverman, A., Fogstad, H., Banerjee, A., Mohan, A., 2020. Adolescent well-being: A definition and conceptual framework. Journal of Adolescent Health 67, 472-476. https://doi.org/10.1016/j.jadohealth.2020.06.042

Ruel, M. T., Alderman, H. 2013. Nutrition-sensitive interventions and programmes: How can they help to accelerate progress in improving maternal and child nutrition? Lancet 382, 536-551. https://doi.org/10.1016/S0140-6736(13)60843-0

Santika, T., Wilson, K. A., Budiharta, S., Law, E. A., Poh, T. M., Ancrenaz, M., Struebig, M. J., Meijaard, E. 2019a. Does oil palm agriculture help alleviate poverty? A multidimensional counterfactual assessment of oil palm development in Indonesia. World Development 120, 105-117. https://doi.org/10.1016/j.worlddev.2019.04.012

Santika, T., Wilson, K. A., Meijaard, E., Budiharta, S., Law, E. E., Sabri, M., Struebig, M., 
Ancrenaz, M., Poh, T. M. 2019b. Changing landscapes, livelihoods and village welfare in the context of oil palm development. Land Use Policy 87, 104073. https://doi.org/10.1016/j.landusepol.2019.104073

Sayer, J., Ghazoul, J., Nelson, P., Boedhihartono, A. K. 2012. Oil palm expansion transforms tropical landscapes and livelihoods. Global Food Secutiry 1, 114-119. https://doi.org/10.1016/j.gfs.2012.10.003

Schaner, S., Das, S. 2016. Female labor force participation in Asia: Indonesia country study. Asian Development Bank Economics Working Paper 474. ADB, Manila. https://doi.org/10.2139/ssrn.2737842

Schneider, F. 2014. Work in the shadow: Micro and macro Results. International Economic Journal 28(3), 365-379. https://doi.org/10.1080/10168737.2014.936924

Schulz, K. F., Grimes, D. A. 2002. Sample size slippages in randomised trials: Exclusions and the lost and wayward. Lancet 359, 781-785. https://doi.org/10.1016/S01406736(02)07882-0

Seaford, C. 2011. Policy: Time to legislate for the good life. Nature 477, 532-533. https://doi.org/10.1038/477532a

Sekabira, H., Qaim, M. 2017. Can mobile phones improve gender equality and nutrition? Panel data evidence from farm households in Uganda. Food Policy 73, 95-103. https://doi.org/10.1016/j.foodpol.2017.10.004

Sibhatu, K. T. 2019. Oil palm boom and farm household diets in the tropics. Frontiers in Sustainable Food Systems, 3. https://doi.org/10.3389/fsufs.2019.00075

Sibhatu, K. T., Krishna, V. V., Qaim, M. 2015. Production diversity and dietary diversity in smallholder farm households. Proceedings of the National Academy of Sciences of the United States of America 112, 10657-10662. https://doi.org/10.1073/pnas.1510982112

Sibhatu, K. T., Qaim, M. 2018. Review: Meta-analysis of the association between production diversity, diets, and nutrition in smallholder farm households. Food Policy 77, 1-18. https://doi.org/https://doi.org/10.1016/j.foodpol.2018.04.013

Steptoe, A., Deaton, A., Stone, A. A. 2015. Subjective wellbeing, health, and ageing. Lancet 385, 640-648. https://doi.org/10.1016/S0140-6736(13)61489-0

Sununtnasuk, C., Fiedler, J. L. 2017. Can household-based food consumption surveys be used 
to make inferences about nutrient intakes and inadequacies? A Bangladesh case study. Food Policy 72, 121-131. https://doi.org/https://doi.org/10.1016/j.foodpol.2017.08.018

Susanti, A., Maryudi, A. 2016. Development narratives, notions of forest crisis, and boom of oil palm plantations in Indonesia. Forest Policy and Economics 73, 130-139. https://doi.org/10.1016/j.forpol.2016.09.009

Susila, W. R. 2004. Contribution of oil palm industry to economic growth and poverty alleviation in Indonesia. Jurnal Litbang Pertanian 23, 107-114.

Taridala, S., Hardiansyah, H., Siregar, H. 2010. Analisis peran gender dalam pencapaian ketahanan pangan rumah tangga petani di Kabupaten Konawe Selatan, Provinsi Sulawesi Tenggara. Forum Pascasarjana 33, 263-274.

Tavenner, K., Crane, T.A. 2018. Gender power in Kenyan dairy: Cows, commodities, and commercialization. Agriculture and Human Values 35, 701-715.

Thiede, B. C., Gray, C. L. 2017. Heterogeneous climate effects on human migration in Indonesia. Population and Environment 39(2), 147-172. https://doi.org/10.1007/s11111$016-0265-8$

UN General Assembly. 2015. Transforming our world: the 2030 agenda for sustainable development. United Nations, New York.

USDA. 2016. National nutrient database for standard reference. United States Department of Agriculture, Washington, DC.

Villamor, G. B., Akiefnawati, R., Van Noordwijk, M., Desrianti, F., Pradhan, U. 2015. Land use change and shifts in gender roles in central Sumatra, Indonesia. International Forestry Review 17, 61-75. https://doi.org/10.1505/146554815816086444

de Vos, R., Delabre, I. 2018. Spaces for participation and resistance: gendered experiences of oil palm plantation development. Geoforum 96, 217-226. https://doi.org/10.1016/j.geoforum.2018.08.011

Western, M., Tomaszewski, W. 2016. Subjective wellbeing, objective wellbeing and inequality in Australia. PLoS One 11, e0163345. https://doi.org/10.1371/journal.pone.0163345

WHO, 2017. State of health inequality: Indonesia. World Health Organization, Geneva. 
Williams, L. B. 1990. Development, demography, and family decision-making: the status of women in rural Java. Westview Press, Inc., Boulder.

Wing, C., Simon, K., Bello-Gomez, R. A. 2018. Designing difference in difference studies: Best practices for public health policy research. Annual Review of Public Health 39, 453-469. https://doi.org/10.1146/annurev-publhealth-040617-013507

Winoto, J., Siregar, H. 2008. Agricultural development in Indonesia: Current problems, issues, and policies. Analisis Kebijakan Pertanian 6(1), 11-36.

Wooldridge, J. M., 2002. Econometric analysis of cross section and panel data. MIT Press, Cambridge, MA.

World Bank. 2020. Agriculture, forestry, and fishing, value added (\% of GDP) - Indonesia. Retrieved from https://data.worldbank.org/indicator/NV.AGR.TOTL.ZS?locations=ID

Zen, Z., Barlow, C., Gondowarsito, R. 2006. Oil palm in Indonesian socio-economic improvement: a review of options. Oil Palm Industry Economic Journal 6(1), 1-25.

Zen, Z., Barlow, C., Gondowarsito, R., McCarthy, J. F. 2016. Interventions to promote smallholder oil palm and socio-economic improvement in Indonesia, in: Cramb, R., McCarthy, J.F. (Eds.), The Oil Palm Complex Smallhoders, Agribusiness and the State in Indonesia and Malaysia. NUS Press, Singapore, pp. 78-108.

Zezza, A., Carletto, C., Fiedler, J. L., Gennari, P., Jolliffe, D. 2017. Food counts. Measuring food consumption and expenditures in household consumption and expenditure surveys (HCES): Introduction to the special issue. Food Policy 72, 1-6. https://doi.org/10.1016/j.foodpol.2017.08.007

Zhang, L., Yi, H., Luo, R., Liu, C., Rozelle, S. 2013. The human capital roots of the middle income trap: The case of China. Agricultural Economics 44, 151-162. https://doi.org/10.1111/agec.12059

Zivin, J.G., Neidell, M. 2013. Environment, health, and human capital. Journal of Economic Literature 51, 689-730. https://doi.org/10.1257/jel.51.3.689 


\section{Appendices}

\section{Appendix of Chapter 2}

Table A. 1 Attrition probit model

\begin{tabular}{lc}
\hline & Attrition (dummy) \\
\hline Oil palm (dummy) & -0.053 \\
Total land size(ha) & $(0.169)$ \\
& -0.003 \\
Age of household head & $(0.012)$ \\
& $0.011 *$ \\
Education of household head (years) & $(0.007)$ \\
& 0.010 \\
Melayu (dummy) & $(0.023)$ \\
Expenditures (log) & -0.006 \\
& $(0.155)$ \\
Constant & 0.116 \\
& $(0.158)$ \\
Number of observations & $-2.407 * *$ \\
R-squared & $(0.551)$ \\
Chi2 & 701 \\
\hline Notes: Coefficients are & 0.011 \\
\end{tabular}

Notes: Coefficients are shown with standard errors in parentheses. All independent variables are 2012 values. $*, * *, * * *$ significant at the $10 \%, 5 \%$, and $1 \%$ level, respectively. 
Table A. 2 Association between oil palm cultivation in 2012 and nutrition indicators in 2015

\begin{tabular}{|c|c|c|c|c|c|}
\hline & DDS & Calories $(\log )$ & Vit. A $(\log )$ & Zinc $(\log )$ & Iron $(\log )$ \\
\hline Oil palm only (dummy) & $\begin{array}{c}0.510 * * * \\
(0.143)\end{array}$ & $\begin{array}{c}0.142 * * * \\
(0.044)\end{array}$ & $\begin{array}{c}0.417 * * * \\
(0.129)\end{array}$ & $\begin{array}{c}0.213 * * * \\
(0.049)\end{array}$ & $\begin{array}{c}0.267 * * * \\
(0.067)\end{array}$ \\
\hline Oil palm plus rubber (dummy) & $\begin{array}{c}0.326^{* * *} * \\
(0.123)\end{array}$ & $\begin{array}{c}0.122 * * * \\
(0.038)\end{array}$ & $\begin{array}{c}0.233 * * \\
(0.111)\end{array}$ & $\begin{array}{c}0.125^{* * *} * \\
(0.042)\end{array}$ & $\begin{array}{c}0.181 * * * \\
(0.058)\end{array}$ \\
\hline Total land size (ha) & $\begin{array}{l}3.68 \mathrm{e}-4 \\
(0.007)\end{array}$ & $\begin{array}{c}0.008 * * * \\
(0.002)\end{array}$ & $\begin{array}{c}0.016 * * \\
(0.006)\end{array}$ & $\begin{array}{c}0.006 * * \\
(0.002)\end{array}$ & $\begin{array}{l}0.006^{*} \\
(0.003)\end{array}$ \\
\hline Female-headed household (dummy) & $\begin{array}{c}-0.451^{*} \\
(0.266)\end{array}$ & $\begin{array}{c}0.033 \\
(0.082)\end{array}$ & $\begin{array}{l}-0.156 \\
(0.240)\end{array}$ & $\begin{array}{c}0.084 \\
(0.091)\end{array}$ & $\begin{array}{c}0.159 \\
(0.125)\end{array}$ \\
\hline Number of adult women in the household & $\begin{array}{c}0.121 \\
(0.079)\end{array}$ & $\begin{array}{l}-0.019 \\
(0.024)\end{array}$ & $\begin{array}{c}0.003 \\
(0.071)\end{array}$ & $\begin{array}{l}-0.017 \\
(0.027)\end{array}$ & $\begin{array}{l}-0.028 \\
(0.037)\end{array}$ \\
\hline Number of adult men in the household & $\begin{array}{c}-0.082 \\
(0.066)\end{array}$ & $\begin{array}{c}-0.046 * * \\
(0.020)\end{array}$ & $\begin{array}{c}-0.022 \\
(0.059)\end{array}$ & $\begin{array}{l}-0.027 \\
(0.022)\end{array}$ & $\begin{array}{c}-0.025 \\
(0.031)\end{array}$ \\
\hline Number of children in the household & $\begin{array}{c}0.116^{* *} \\
(0.051)\end{array}$ & $\begin{array}{l}-0.020 \\
(0.016)\end{array}$ & $\begin{array}{l}-0.053 \\
(0.046)\end{array}$ & $\begin{array}{c}0.005 \\
(0.017)\end{array}$ & $\begin{array}{l}-0.017 \\
(0.024)\end{array}$ \\
\hline Mean education of adult women (years) & $\begin{array}{c}0.050 * * * \\
(0.019)\end{array}$ & $\begin{array}{c}0.012 * * \\
(0.006)\end{array}$ & $\begin{array}{c}0.049 * * * \\
(0.017)\end{array}$ & $\begin{array}{c}0.016 * * \\
(0.007)\end{array}$ & $\begin{array}{c}0.018 * * \\
(0.009)\end{array}$ \\
\hline Mean education of adult men (years) & $\begin{array}{c}0.061 * * * \\
(0.019)\end{array}$ & $\begin{array}{c}0.007 \\
(0.006)\end{array}$ & $\begin{array}{c}0.038 * * \\
(0.017)\end{array}$ & $\begin{array}{l}-0.001 \\
(0.007)\end{array}$ & $\begin{array}{c}0.007 \\
(0.009)\end{array}$ \\
\hline Mean age of adult women & $\begin{array}{c}0.002 \\
(0.007)\end{array}$ & $\begin{array}{c}0.001 \\
(0.002)\end{array}$ & $\begin{array}{c}-0.002 \\
(0.006)\end{array}$ & $\begin{array}{c}0.001 \\
(0.002)\end{array}$ & $\begin{array}{c}0.001 \\
(0.003)\end{array}$ \\
\hline Mean age of adult men & $\begin{array}{c}0.001 \\
(0.006)\end{array}$ & $\begin{array}{c}0.001 \\
(0.002)\end{array}$ & $\begin{array}{c}0.009 \\
(0.006)\end{array}$ & $\begin{array}{l}1.57 \mathrm{e}-4 \\
(0.002)\end{array}$ & $\begin{array}{c}0.001 \\
(0.003)\end{array}$ \\
\hline Access to formal credit (dummy) & $\begin{array}{c}0.062 \\
(0.115)\end{array}$ & $\begin{array}{l}-0.031 \\
(0.035)\end{array}$ & $\begin{array}{l}-0.065 \\
(0.103)\end{array}$ & $\begin{array}{c}-0.045 \\
(0.039)\end{array}$ & $\begin{array}{l}-0.005 \\
(0.054)\end{array}$ \\
\hline Melayu (dummy) & $\begin{array}{c}-0.124 \\
(0.099)\end{array}$ & $\begin{array}{c}-0.052 * \\
(0.031)\end{array}$ & $\begin{array}{c}-0.148 * \\
(0.090)\end{array}$ & $\begin{array}{c}-0.096^{* * * *} \\
(0.034)\end{array}$ & $\begin{array}{c}-0.131 * * * \\
(0.047)\end{array}$ \\
\hline Non-random village (dummy) & $\begin{array}{c}0.359 * * \\
(0.145)\end{array}$ & $\begin{array}{l}0.085^{*} \\
(0.045)\end{array}$ & $\begin{array}{c}0.160 \\
(0.130)\end{array}$ & $\begin{array}{c}0.070 \\
(0.049)\end{array}$ & $\begin{array}{c}0.074 \\
(0.068)\end{array}$ \\
\hline Distance to market $(\mathrm{km})$ & $\begin{array}{c}0.015 * * \\
(0.006)\end{array}$ & $\begin{array}{l}-0.001 \\
(0.002)\end{array}$ & $\begin{array}{c}0.003 \\
(0.006)\end{array}$ & $\begin{array}{c}-0.002 \\
(0.002)\end{array}$ & $\begin{array}{l}1.45 \mathrm{e}-4 \\
(0.003)\end{array}$ \\
\hline Constant & $\begin{array}{c}5.338 * * * \\
(0.386)\end{array}$ & $\begin{array}{c}7.697 * * * \\
(0.120)\end{array}$ & $\begin{array}{c}5.308 * * * \\
(0.348)\end{array}$ & $\begin{array}{c}2.147 * * * \\
(0.132)\end{array}$ & $\begin{array}{c}2.518 * * * \\
(0.182)\end{array}$ \\
\hline R-squared & $\begin{array}{c}0.101 \\
646\end{array}$ & 0.102 & 0.081 & 0.079 & 0.067 \\
\hline
\end{tabular}

Notes: Coefficient estimates of cross-section models are shown with standard errors in parentheses. All dependent variables refer to 2015; all explanatory variables refer to 2012. Only households observed in 2012 and 2015 included. $* * *, * * *$ significant at the $10 \%, 5 \%$, and $1 \%$ level, respectively. 
Table A. 3 Associations between oil palm cultivation and nutrition using transmigration variables

\begin{tabular}{lccccc}
\hline & DDS & Calorie $(\log )$ & Vit. A $(\log )$ & Zinc $(\log )$ & Iron $(\log )$ \\
\hline Oil palm (dummy) & $0.353^{* * *}$ & $0.102^{* * *}$ & $0.241^{* * *}$ & $0.109^{* * *}$ & $0.178^{* * *}$ \\
& $(0.095)$ & $(0.024)$ & $(0.068)$ & $(0.025)$ & $(0.035)$ \\
Transmigrant village (dummy) & $0.257^{* *}$ & $0.057^{* *}$ & 0.040 & $0.075^{* *}$ & $0.181^{* * *}$ \\
& $(0.120)$ & $(0.029)$ & $(0.111)$ & $(0.030)$ & $(0.055)$ \\
Oil palm x transmigrant village (interaction) & -0.105 & 0.018 & 0.063 & 0.028 & -0.042 \\
& $(0.182)$ & $(0.060)$ & $(0.158)$ & $(0.054)$ & $(0.075)$ \\
Constant & $5.810^{* * *}$ & $7.850^{* * *}$ & $5.705^{* * *}$ & $2.302^{* * *}$ & $2.567^{* * *}$ \\
& $(0.324)$ & $(0.071)$ & $(0.242)$ & $(0.072)$ & $(0.122)$ \\
R-squared & 0.100 & 0.180 & 0.105 & 0.129 & 0.134 \\
Chi2 & 268.774 & 340.000 & 291.405 & 432.614 & 357.975 \\
Number of observations & 1362 & 1362 & 1362 & 1362 & 1362 \\
\hline
\end{tabular}

Notes: Coefficient estimates of panel data random effects models are shown with standard errors in parentheses. $*, * *, * * *$ significant at the $10 \%, 5 \%$, and $1 \%$ level, respectively. 
Table A. 4 Association between household expenditures in 2012 and nutrition indicators in 2015

\begin{tabular}{|c|c|c|c|c|c|}
\hline & DDS & Calories $(\log )$ & Vit. A (log) & Zinc $(\log )$ & Iron $(\log )$ \\
\hline Expenditures (log) & $\begin{array}{c}0.420 * * * \\
(0.104)\end{array}$ & $\begin{array}{c}0.143 * * * \\
(0.032)\end{array}$ & $\begin{array}{c}0.426 * * * \\
(0.093)\end{array}$ & $\begin{array}{c}0.107 * * * \\
(0.036)\end{array}$ & $\begin{array}{c}0.212 * * * \\
(0.049)\end{array}$ \\
\hline Total land size (ha) & $\begin{array}{l}-0.008 \\
(0.007)\end{array}$ & $\begin{array}{c}0.005 * * \\
(0.002)\end{array}$ & $\begin{array}{c}0.006 \\
(0.007)\end{array}$ & $\begin{array}{l}0.004 * \\
(0.003)\end{array}$ & $\begin{array}{c}0.002 \\
(0.003)\end{array}$ \\
\hline Female-headed household (dummy) & $\begin{array}{c}-0.466^{*} \\
(0.266)\end{array}$ & $\begin{array}{c}0.030 \\
(0.082)\end{array}$ & $\begin{array}{l}-0.161 \\
(0.238)\end{array}$ & $\begin{array}{c}0.073 \\
(0.092)\end{array}$ & $\begin{array}{c}0.151 \\
(0.126)\end{array}$ \\
\hline Number of adult women in the household & $\begin{array}{l}0.133^{*} \\
(0.079)\end{array}$ & $\begin{array}{l}-0.014 \\
(0.024)\end{array}$ & $\begin{array}{c}0.018 \\
(0.071)\end{array}$ & $\begin{array}{l}-0.017 \\
(0.027)\end{array}$ & $\begin{array}{l}-0.023 \\
(0.037)\end{array}$ \\
\hline Number of adult men in the household & $\begin{array}{l}-0.057 \\
(0.066)\end{array}$ & $\begin{array}{c}-0.037^{*} \\
(0.020)\end{array}$ & $\begin{array}{c}0.002 \\
(0.059)\end{array}$ & $\begin{array}{l}-0.020 \\
(0.023)\end{array}$ & $\begin{array}{l}-0.012 \\
(0.031)\end{array}$ \\
\hline Number of children in the household & $\begin{array}{c}0.173 * * * \\
(0.052)\end{array}$ & $\begin{array}{c}-0.002 \\
(0.016)\end{array}$ & $\begin{array}{c}0.002 \\
(0.046)\end{array}$ & $\begin{array}{c}0.021 \\
(0.018)\end{array}$ & $\begin{array}{c}0.012 \\
(0.024)\end{array}$ \\
\hline Mean education of adult women (years) & $\begin{array}{c}0.037 * \\
(0.019)\end{array}$ & $\begin{array}{c}0.007 \\
(0.006)\end{array}$ & $\begin{array}{c}0.038 * * \\
(0.017)\end{array}$ & $\begin{array}{l}0.012 * \\
(0.007)\end{array}$ & $\begin{array}{c}0.012 \\
(0.009)\end{array}$ \\
\hline Mean education of adult men (years) & $\begin{array}{c}0.057 * * * \\
(0.019)\end{array}$ & $\begin{array}{c}0.006 \\
(0.006)\end{array}$ & $\begin{array}{c}0.033^{*} \\
(0.017)\end{array}$ & $\begin{array}{l}-0.001 \\
(0.007)\end{array}$ & $\begin{array}{c}0.005 \\
(0.009)\end{array}$ \\
\hline Mean age of adult women & $\begin{array}{c}0.001 \\
(0.007)\end{array}$ & $\begin{array}{c}0.001 \\
(0.002)\end{array}$ & $\begin{array}{c}-0.003 \\
(0.006)\end{array}$ & $\begin{array}{c}0.001 \\
(0.002)\end{array}$ & $\begin{array}{l}1.97 e-5 \\
(0.003)\end{array}$ \\
\hline Mean age of adult men & $\begin{array}{c}0.002 \\
(0.006)\end{array}$ & $\begin{array}{c}0.002 \\
(0.002)\end{array}$ & $\begin{array}{l}0.010 * \\
(0.006)\end{array}$ & $\begin{array}{c}0.001 \\
(0.002)\end{array}$ & $\begin{array}{c}0.001 \\
(0.003)\end{array}$ \\
\hline Access to formal credit (dummy) & $\begin{array}{c}0.096 \\
(0.113)\end{array}$ & $\begin{array}{c}-0.020 \\
(0.035)\end{array}$ & $\begin{array}{c}-0.049 \\
(0.102)\end{array}$ & $\begin{array}{l}-0.026 \\
(0.039)\end{array}$ & $\begin{array}{c}0.014 \\
(0.054)\end{array}$ \\
\hline Melayu (dummy) & $\begin{array}{l}-0.126 \\
(0.099)\end{array}$ & $\begin{array}{c}-0.052 * \\
(0.031)\end{array}$ & $\begin{array}{l}-0.140 \\
(0.089)\end{array}$ & $\begin{array}{c}-0.103 * * * \\
(0.034)\end{array}$ & $\begin{array}{c}-0.133 * * * \\
(0.047)\end{array}$ \\
\hline Non-random village (dummy) & $\begin{array}{c}0.333^{* *} * \\
(0.143)\end{array}$ & $\begin{array}{l}0.080 * \\
(0.044)\end{array}$ & $\begin{array}{c}0.123 \\
(0.128)\end{array}$ & $\begin{array}{c}0.064 \\
(0.049)\end{array}$ & $\begin{array}{c}0.063 \\
(0.068)\end{array}$ \\
\hline Distance to market $(\mathrm{km})$ & $\begin{array}{c}0.015 * * \\
(0.006)\end{array}$ & $\begin{array}{l}-0.001 \\
(0.002)\end{array}$ & $\begin{array}{c}0.003 \\
(0.006)\end{array}$ & $\begin{array}{l}-0.002 \\
(0.002)\end{array}$ & $\begin{array}{l}2.60 \mathrm{e}-4 \\
(0.003)\end{array}$ \\
\hline Constant & $\begin{array}{c}4.455 * * * \\
(0.459)\end{array}$ & $\begin{array}{c}7.395 * * * \\
(0.142)\end{array}$ & $\begin{array}{c}4.382 * * * \\
(0.411)\end{array}$ & $\begin{array}{c}1.942 * * * \\
(0.158)\end{array}$ & $\begin{array}{c}2.077 * * * \\
(0.217)\end{array}$ \\
\hline R-squared & 0.102 & 0.107 & 0.095 & 0.060 & 0.065 \\
\hline Number of observations & 646 & 646 & 646 & 646 & 646 \\
\hline
\end{tabular}

Notes: Coefficient estimates of cross-section models are shown with standard errors in parentheses. All dependent variables refer to 2015; all explanatory variables refer to 2012. Only households observed in 2012 and 2015 included. *,**, *** significant at the $10 \%, 5 \%$, and $1 \%$ level, respectively. 
Table A. 5 Association between oil palm cultivation in 2012 and labor allocation in 2015

\begin{tabular}{|c|c|c|c|c|}
\hline & \multicolumn{2}{|c|}{ On-farm work (hours/year) } & \multicolumn{2}{|c|}{ Off-farm employment (dummy) } \\
\hline & $\begin{array}{c}\text { (1) } \\
\text { Female labor }\end{array}$ & $\begin{array}{c}(2) \\
\text { Male labor }\end{array}$ & $\begin{array}{c}(3) \\
\text { Female } \\
\text { employment }\end{array}$ & $\begin{array}{c}\text { (4) } \\
\text { Male } \\
\text { employment }\end{array}$ \\
\hline \multirow[t]{2}{*}{ Oil palm only (dummy) } & $-525.680 * * *$ & $-799.145 * * *$ & $0.544 * *$ & $0.918 * * *$ \\
\hline & $(76.538)$ & $(118.885)$ & $(0.253)$ & $(0.304)$ \\
\hline \multirow[t]{2}{*}{ Oil palm plus rubber (dummy) } & -79.398 & -5.495 & 0.095 & -0.055 \\
\hline & $(65.830)$ & $(102.252)$ & $(0.228)$ & $(0.226)$ \\
\hline \multirow[t]{2}{*}{ Total land size (ha) } & -2.728 & -0.153 & -0.016 & -0.011 \\
\hline & $(3.696)$ & $(5.741)$ & $(0.015)$ & $(0.012)$ \\
\hline \multirow[t]{2}{*}{ Female-headed household (dummy) } & -140.450 & -158.086 & -0.341 & $-0.937 *$ \\
\hline & $(142.491)$ & $(221.328)$ & $(0.507)$ & $(0.478)$ \\
\hline \multirow[t]{2}{*}{ Number of adult women in the household } & -5.928 & 54.585 & 0.231 & -0.023 \\
\hline & $(42.147)$ & $(65.467)$ & $(0.142)$ & $(0.147)$ \\
\hline \multirow[t]{2}{*}{ Number of adult men in the household } & -6.545 & $116.078 * *$ & -0.149 & 0.048 \\
\hline & $(35.261)$ & $(54.771)$ & $(0.125)$ & $(0.124)$ \\
\hline \multirow[t]{2}{*}{ Number of children in the household } & -16.086 & -68.813 & 0.051 & $0.159 *$ \\
\hline & $(27.074)$ & $(42.053)$ & $(0.093)$ & $(0.097)$ \\
\hline \multirow[t]{2}{*}{ Mean education of adult women (years) } & -2.373 & 16.393 & 0.038 & -0.048 \\
\hline & $(10.281)$ & $(15.970)$ & $(0.036)$ & $(0.036)$ \\
\hline \multirow[t]{2}{*}{ Mean education of adult men (years) } & -5.860 & $-38.586 * *$ & 0.034 & $0.105 * * *$ \\
\hline & $(10.381)$ & $(16.125)$ & $(0.036)$ & $(0.037)$ \\
\hline \multirow[t]{2}{*}{ Mean age of adult women } & -1.597 & 2.575 & 0.001 & -0.017 \\
\hline & $(3.519)$ & $(5.467)$ & $(0.012)$ & $(0.012)$ \\
\hline \multirow[t]{2}{*}{ Mean age of adult men } & 0.732 & -4.639 & 0.003 & $-0.032 * * *$ \\
\hline & $(3.350)$ & $(5.204)$ & $(0.012)$ & $(0.012)$ \\
\hline \multirow{2}{*}{ Access to formal credit (dummy) } & -14.116 & -84.431 & 0.249 & 0.172 \\
\hline & $(61.367)$ & $(95.321)$ & $(0.207)$ & $(0.216)$ \\
\hline \multirow[t]{2}{*}{ Melayu (dummy) } & $-131.473 * *$ & $-266.594 * * *$ & 0.138 & $0.376^{* *}$ \\
\hline & $(53.217)$ & $(82.660)$ & $(0.184)$ & $(0.186)$ \\
\hline \multirow[t]{2}{*}{ Non-random village (dummy) } & -59.658 & 145.523 & $0.434 *$ & 0.022 \\
\hline & $(77.367)$ & $(120.173)$ & $(0.260)$ & $(0.268)$ \\
\hline \multirow[t]{2}{*}{ Distance to market $(\mathrm{km})$} & $-5.842 *$ & -0.755 & 0.016 & 0.004 \\
\hline & $(3.390)$ & $(5.266)$ & $(0.011)$ & $(0.012)$ \\
\hline \multirow{2}{*}{ Constant } & $809.614 * * *$ & $1.273 .020 * * *$ & $-1.945 * * *$ & $1.499 * *$ \\
\hline & $(206.861)$ & $(321.312)$ & $(0.716)$ & $(0.727)$ \\
\hline Number of observations & 646 & 646 & 646 & 646 \\
\hline
\end{tabular}

Notes: Coefficient estimates of cross-section models are shown with standard errors in parentheses. All dependent variables refer to 2015; all explanatory variables refer to 2012. Only households observed in 2012 and 2015 included. *,**,*** significant at the $10 \%, 5 \%$, and $1 \%$ level, respectively. 
Table A. 6 Association between female and male labor allocation and nutrition indicators

\begin{tabular}{|c|c|c|c|c|c|}
\hline & DDS & Calories (log) & Vit. A (log) & Zinc (log) & Iron $(\log )$ \\
\hline \multirow{2}{*}{$\begin{array}{l}\text { Female off-farm employment } \\
\text { (dummy) }\end{array}$} & $0.218 * * *$ & $0.082 * * *$ & $0.223 * * *$ & $0.068 * * *$ & $0.110 * * *$ \\
\hline & $(0.075)$ & $(0.029)$ & $(0.068)$ & $(0.024)$ & $(0.033)$ \\
\hline \multirow{2}{*}{$\begin{array}{l}\text { Male off-farm employment } \\
\text { (dummy) }\end{array}$} & -0.025 & 0.009 & -0.007 & 0.001 & -0.034 \\
\hline & $(0.071)$ & $(0.026)$ & $(0.062)$ & $(0.028)$ & $(0.036)$ \\
\hline \multirow{2}{*}{$\begin{array}{l}\text { Female on-farm work } \\
\text { (hours/year) }\end{array}$} & $-7.68 e-5$ & $-2.02 \mathrm{e}-5$ & $-1.11 \mathrm{e}-4 * *$ & $-1.19 e-5$ & $-1.7 e-5$ \\
\hline & $(6.35 \mathrm{e}-5)$ & $(2.11 \mathrm{e}-5)$ & $(5.1 \mathrm{e}-5)$ & $(2.32 \mathrm{e}-5)$ & $(2.91 \mathrm{e}-5)$ \\
\hline \multirow{2}{*}{$\begin{array}{l}\text { Male on-farm work } \\
\text { (hours/year) }\end{array}$} & $-1.20 \mathrm{e}-6$ & $1.7 e-5$ & $1.16 \mathrm{e}-5$ & $9.54 \mathrm{e}-6$ & $2.86 \mathrm{e}-6$ \\
\hline & $(4.08 \mathrm{e}-5)$ & $(1.31 \mathrm{e}-5)$ & $(3.87 e-5)$ & $(1.48 \mathrm{e}-5)$ & $(1.78 \mathrm{e}-5)$ \\
\hline \multirow[t]{2}{*}{ Total land size (ha) } & $0.010 * *$ & $0.009 * * *$ & $0.016 * * *$ & $0.009 * * *$ & $0.010 * * *$ \\
\hline & $(0.004)$ & $(0.003)$ & $(0.005)$ & $(0.003)$ & $(0.003)$ \\
\hline \multirow{2}{*}{$\begin{array}{l}\text { Female-headed households } \\
\text { (dummy) }\end{array}$} & $-0.384 * *$ & -0.005 & -0.265 & -0.036 & -0.011 \\
\hline & $(0.170)$ & $(0.063)$ & $(0.163)$ & $(0.060)$ & $(0.077)$ \\
\hline \multirow{2}{*}{$\begin{array}{l}\text { Number of adult women in } \\
\text { the household }\end{array}$} & 0.062 & $-0.079 * * *$ & -0.076 & $-0.063 * * *$ & $-0.098 * * *$ \\
\hline & $(0.052)$ & $(0.017)$ & $(0.05)$ & $(0.018)$ & $(0.026)$ \\
\hline \multirow{2}{*}{$\begin{array}{l}\text { Number of adult men in the } \\
\text { household }\end{array}$} & 0.052 & $-0.047 * * *$ & -0.052 & $-0.043^{* * *}$ & -0.009 \\
\hline & $(0.041)$ & $(0.017)$ & $(0.037)$ & $(0.016)$ & $(0.021)$ \\
\hline \multirow{2}{*}{$\begin{array}{l}\text { Number of children in the } \\
\text { household }\end{array}$} & 0.022 & $-0.072 * * *$ & $-0.080 * *$ & $-0.050 * * *$ & $-0.068 * * *$ \\
\hline & $(0.043)$ & $(0.011)$ & $(0.037)$ & $(0.010)$ & $(0.019)$ \\
\hline \multirow{2}{*}{$\begin{array}{l}\text { Mean education of adult } \\
\text { women (years) }\end{array}$} & $0.038 * * *$ & $0.011 * * *$ & $0.034 * * *$ & $0.009 *$ & $0.017 * * *$ \\
\hline & $(0.014)$ & $(0.004)$ & $(0.011)$ & $(0.005)$ & $(0.005)$ \\
\hline \multirow{2}{*}{$\begin{array}{l}\text { Mean education of adult men } \\
\text { (years) }\end{array}$} & $0.038 * * *$ & 0.005 & $0.034 * * *$ & 0.001 & $0.011 *$ \\
\hline & $(0.013)$ & $(0.004)$ & $(0.012)$ & $(0.005)$ & $(0.006)$ \\
\hline \multirow[t]{2}{*}{ Mean age of adult women } & -0.006 & 0.001 & -0.001 & $-2.78 \mathrm{e}-1$ & -0.002 \\
\hline & $(0.004)$ & $(0.001)$ & $(0.003)$ & $(0.002)$ & $(0.002)$ \\
\hline \multirow[t]{2}{*}{ Mean age of adult men } & 0.000 & $0.002 * *$ & 0.005 & $4.66 \mathrm{e}-01$ & $0.003 *$ \\
\hline & $(0.005)$ & $(0.001)$ & $(0.004)$ & $(0.001)$ & $(0.002)$ \\
\hline \multirow{2}{*}{$\begin{array}{l}\text { Access to formal credit } \\
\text { (dummy) }\end{array}$} & 0.007 & $0.059 * *$ & 0.046 & $0.062 * *$ & 0.061 \\
\hline & $(0.082)$ & $(0.026)$ & $(0.057)$ & $(0.030)$ & $(0.039)$ \\
\hline \multirow[t]{2}{*}{ Melayu (dummy) } & $-0.299 * * *$ & -0.032 & $-0.139 * *$ & $-0.078 * * *$ & $-0.129 * * *$ \\
\hline & $(0.071)$ & $(0.023)$ & $(0.057)$ & $(0.023)$ & $(0.039)$ \\
\hline \multirow[t]{2}{*}{ Non-random village (dummy) } & $0.381 * * *$ & $0.082 *$ & $0.200 * * *$ & $0.075 * * *$ & 0.074 \\
\hline & $(0.114)$ & $(0.042)$ & $(0.069)$ & $(0.028)$ & $(0.057)$ \\
\hline \multirow[t]{2}{*}{ Distance to market (km) } & 0.002 & $-4.39 \mathrm{e}-01$ & 0.006 & -0.002 & 0.002 \\
\hline & $(0.006)$ & $(0.002)$ & $(0.004)$ & $(0.002)$ & $(0.003)$ \\
\hline \multirow[t]{2}{*}{ Survey round 2015 (dummy) } & 0.022 & $-0.107 * * *$ & $-0.168 * * *$ & $-0.065^{*}$ & $-0.143 * * *$ \\
\hline & $(0.068)$ & $(0.029)$ & $(0.055)$ & $(0.034)$ & $(0.037)$ \\
\hline \multirow[t]{2}{*}{ Constant } & $6.204 * * *$ & $7.911 * * *$ & $5.933 * * *$ & $2.405^{* * *}$ & $2.768 * * *$ \\
\hline & $(0.338)$ & $(0.073)$ & $(0.242)$ & $(0.075)$ & $(0.128)$ \\
\hline R-squared & 0.098 & 0.170 & 0.108 & 0.116 & 0.117 \\
\hline Chi2 & 344.093 & 258.313 & 228.944 & 227.535 & 192.019 \\
\hline Number of observations & 1362 & 1362 & 1362 & 1362 & 1362 \\
\hline
\end{tabular}

Notes: Coefficient estimates of random effects panel models are shown with standard errors in parentheses. *, **, $* * *$ significant at the $10 \%, 5 \%$, and $1 \%$ level, respectively. 


\section{Appendix of Chapter 3}
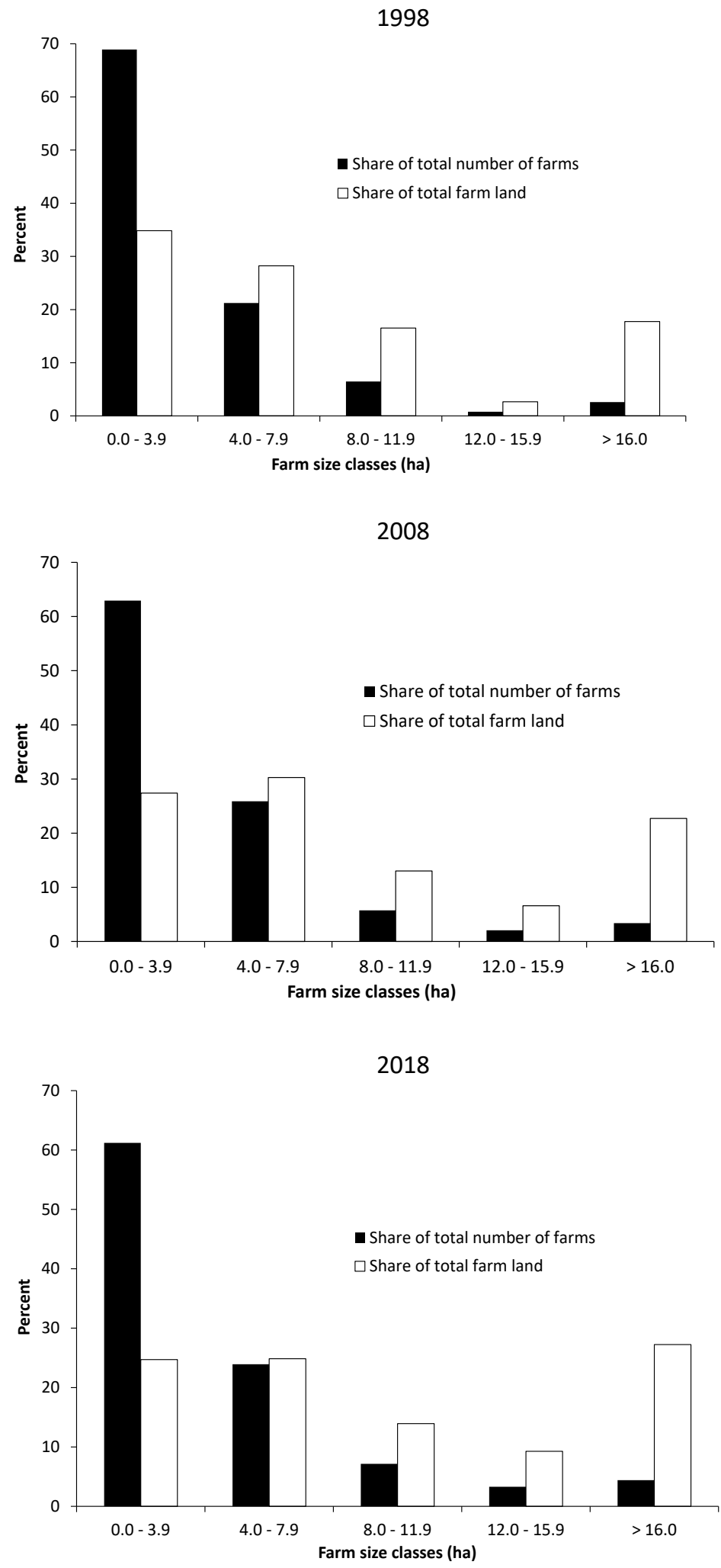

Figure A. 1 Distribution of number of farms and of total farm land in Jambi (1998-2018) 


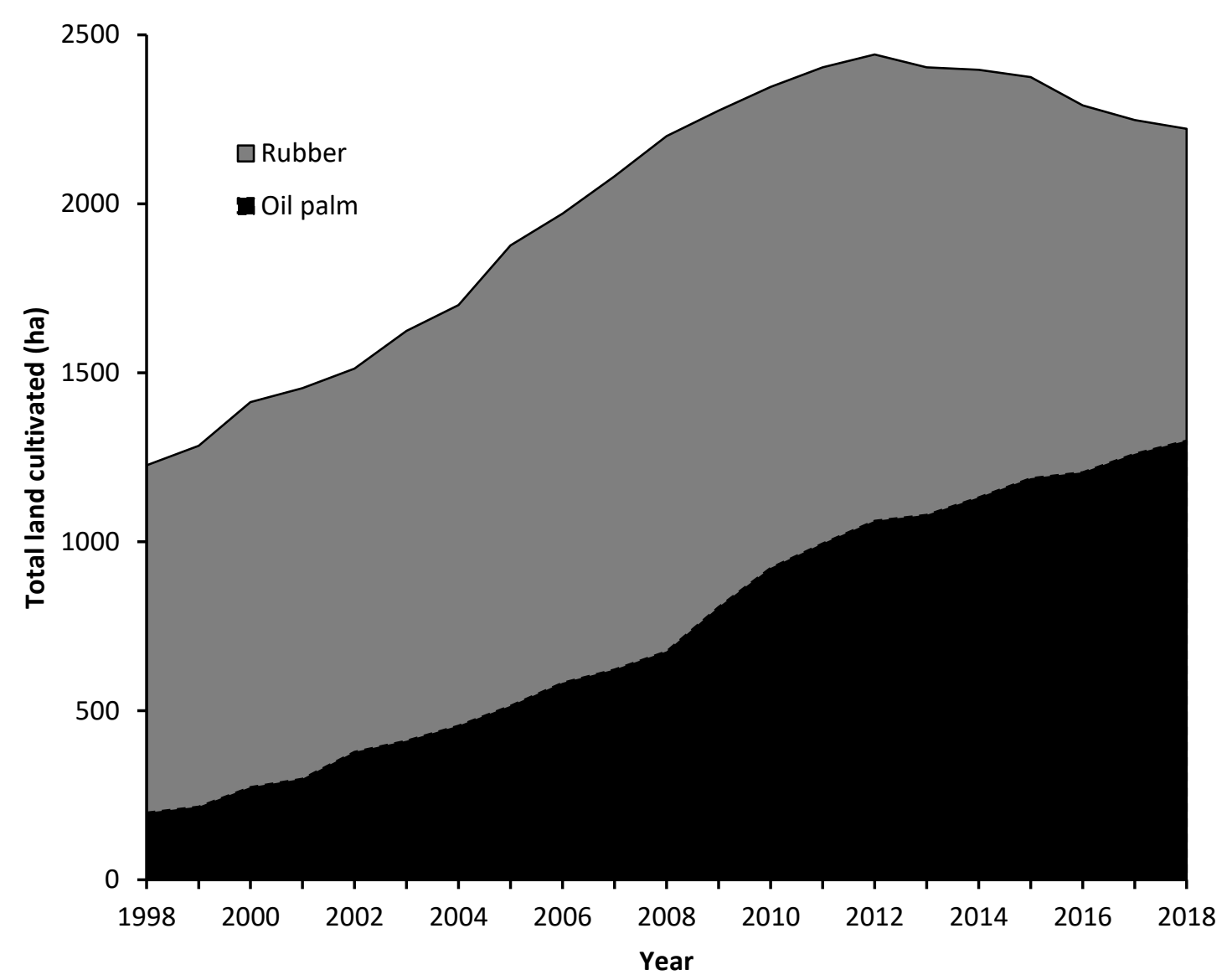

Figure A. 2 Development of total land cultivated by sample farms (1998-2018) 
Table A. 7 Determinants of participation in off-farm activities (RE panel data models)

\begin{tabular}{|c|c|c|c|c|}
\hline \multirow[b]{2}{*}{ Variables } & \multicolumn{3}{|c|}{ Employed activities } & \multirow[b]{2}{*}{ Self-employec } \\
\hline & Agriculture & Manufacturing & Services & \\
\hline \multirow[t]{2}{*}{ Oil palm adoption (dummy) } & -0.029 & 0.005 & 0.003 & $0.067 * * *$ \\
\hline & $(0.021)$ & $(0.016)$ & $(0.019)$ & $(0.023)$ \\
\hline \multirow[t]{2}{*}{ Farm size (land cultivated in ha) } & $-0.006 * * *$ & $-0.002 *$ & -0.002 & $0.004 * * *$ \\
\hline & $(0.001)$ & $(0.001)$ & $(0.001)$ & $(0.002)$ \\
\hline \multirow[t]{2}{*}{ Female-headed household (dummy) } & -0.016 & $0.076 * *$ & $0.075 * *$ & -0.048 \\
\hline & $(0.040)$ & $(0.031)$ & $(0.035)$ & $(0.041)$ \\
\hline \multirow[t]{2}{*}{ Household size } & $0.028 * * *$ & $0.017 * * *$ & $0.035 * * *$ & $0.019 * * *$ \\
\hline & $(0.006)$ & $(0.005)$ & $(0.005)$ & $(0.006)$ \\
\hline \multirow[t]{2}{*}{ Age of household head (years) } & $-0.005 * * *$ & $-0.002 * *$ & $0.003 * * *$ & -0.000 \\
\hline & $(0.001)$ & $(0.001)$ & $(0.001)$ & $(0.001)$ \\
\hline \multirow[t]{2}{*}{ Education of household head (years) } & $-0.011 * * *$ & 0.002 & $0.022 * * *$ & 0.002 \\
\hline & $(0.003)$ & $(0.002)$ & $(0.003)$ & $(0.003)$ \\
\hline \multirow[t]{2}{*}{ Migrant household (dummy) } & $0.038 *$ & -0.004 & -0.014 & $-0.050 * *$ \\
\hline & $(0.022)$ & $(0.016)$ & $(0.019)$ & $(0.024)$ \\
\hline \multirow[t]{2}{*}{ Access to credit (dummy) } & 0.016 & -0.009 & 0.003 & $0.114 * * *$ \\
\hline & $(0.020)$ & $(0.017)$ & $(0.018)$ & $(0.021)$ \\
\hline \multirow[t]{2}{*}{ Non-random village (dummy) } & 0.041 & $-0.051 * *$ & 0.029 & 0.022 \\
\hline & $(0.032)$ & $(0.023)$ & $(0.027)$ & $(0.035)$ \\
\hline \multirow[t]{2}{*}{ Distance to market (km) } & $3.231 \mathrm{e}-4$ & 0.002 & $0.003 * *$ & -0.001 \\
\hline & $(0.002)$ & $(0.001)$ & $(0.001)$ & $(0.002)$ \\
\hline \multirow[t]{2}{*}{ Survey round 2015 (dummy) } & 0.024 & $0.091 * * *$ & 0.012 & $0.058 * * *$ \\
\hline & $(0.020)$ & $(0.018)$ & $(0.018)$ & $(0.019)$ \\
\hline \multirow[t]{2}{*}{ Survey round 2018 (dummy) } & $0.039 *$ & -0.024 & $0.126^{* * *}$ & $0.042 * *$ \\
\hline & $(0.021)$ & $(0.018)$ & $(0.019)$ & $(0.020)$ \\
\hline \multirow[t]{2}{*}{ Constant } & $0.422 * * *$ & $0.101 * *$ & $-0.328 * * *$ & 0.077 \\
\hline & $(0.066)$ & $(0.051)$ & $(0.058)$ & $(0.070)$ \\
\hline Number of observations & 2,060 & 2,060 & 2,060 & 2,060 \\
\hline
\end{tabular}

Notes: Coefficient estimates of linear probability models are shown with standard errors in parentheses. $*, * *, * * *$ significant at the $10 \%, 5 \%$, and $1 \%$ level, respectively. 
Table A. 8 Determinants of participation in off-farm activities (RE logit panel data models)

\begin{tabular}{|c|c|c|c|c|}
\hline \multirow[b]{2}{*}{ Variables } & \multicolumn{3}{|c|}{ Employed activities } & \multirow[b]{2}{*}{ Self-employed } \\
\hline & Agriculture & Manufacturing & Services & \\
\hline Oil palm adoption (dummy) & $\begin{array}{l}-0.044 \\
(0.165)\end{array}$ & $\begin{array}{c}0.079 \\
(0.170)\end{array}$ & $\begin{array}{c}0.045 \\
(0.175)\end{array}$ & $\begin{array}{c}0.542 * * * \\
(0.190)\end{array}$ \\
\hline Farm size (land cultivated in ha) & $\begin{array}{c}-0.165^{* * * *} \\
(0.028)\end{array}$ & $\begin{array}{c}-0.030 * \\
(0.017)\end{array}$ & $\begin{array}{l}-0.021 \\
(0.013)\end{array}$ & $\begin{array}{c}0.028 * * \\
(0.011)\end{array}$ \\
\hline Female-headed household (dummy) & $\begin{array}{l}-0.174 \\
(0.307)\end{array}$ & $\begin{array}{c}0.722 * * \\
(0.293)\end{array}$ & $\begin{array}{l}0.605 * \\
(0.318)\end{array}$ & $\begin{array}{l}-0.429 \\
(0.364)\end{array}$ \\
\hline Household size & $\begin{array}{c}0.226 * * * \\
(0.048)\end{array}$ & $\begin{array}{c}0.175 * * * \\
(0.049)\end{array}$ & $\begin{array}{c}0.316^{* * *} \\
(0.051)\end{array}$ & $\begin{array}{c}0.149 * * * \\
(0.053)\end{array}$ \\
\hline Age of household head (years) & $\begin{array}{c}-0.036 * * * \\
(0.007)\end{array}$ & $\begin{array}{l}-0.015^{*} \\
(0.008)\end{array}$ & $\begin{array}{c}0.023 * * * \\
(0.008)\end{array}$ & $\begin{array}{l}-0.001 \\
(0.009)\end{array}$ \\
\hline Education of household head (years) & $\begin{array}{c}-0.084 * * * \\
(0.024)\end{array}$ & $\begin{array}{c}0.029 \\
(0.024)\end{array}$ & $\begin{array}{c}0.192 * * * \\
(0.025)\end{array}$ & $\begin{array}{c}0.017 \\
(0.027)\end{array}$ \\
\hline Migrant household (dummy) & $\begin{array}{c}0.252 \\
(0.165)\end{array}$ & $\begin{array}{c}-0.034 \\
(0.165)\end{array}$ & $\begin{array}{l}-0.120 \\
(0.177)\end{array}$ & $\begin{array}{c}-0.411 * * \\
(0.202)\end{array}$ \\
\hline Access to credit (dummy) & $\begin{array}{c}0.179 \\
(0.155)\end{array}$ & $\begin{array}{l}-0.093 \\
(0.169)\end{array}$ & $\begin{array}{c}0.019 \\
(0.171)\end{array}$ & $\begin{array}{c}0.884 * * * \\
(0.168)\end{array}$ \\
\hline Non-random village (dummy) & $\begin{array}{l}0.427 * \\
(0.236)\end{array}$ & $\begin{array}{c}-0.574 * * \\
(0.274)\end{array}$ & $\begin{array}{c}0.370 \\
(0.252)\end{array}$ & $\begin{array}{c}0.105 \\
(0.291)\end{array}$ \\
\hline Distance to market $(\mathrm{km})$ & $\begin{array}{l}-0.002 \\
(0.012)\end{array}$ & $\begin{array}{c}0.016 \\
(0.012)\end{array}$ & $\begin{array}{c}0.030 * * \\
(0.013)\end{array}$ & $\begin{array}{c}-0.014 \\
(0.014)\end{array}$ \\
\hline Survey round 2015 (dummy) & $\begin{array}{c}0.166 \\
(0.154)\end{array}$ & $\begin{array}{c}0.793 * * * \\
(0.168)\end{array}$ & $\begin{array}{c}0.153 \\
(0.187)\end{array}$ & $\begin{array}{c}0.481 * * * \\
(0.165)\end{array}$ \\
\hline Survey round 2018 (dummy) & $\begin{array}{c}0.251 \\
(0.160)\end{array}$ & $\begin{array}{l}-0.352 * \\
(0.200)\end{array}$ & $\begin{array}{c}1.150 * * * \\
(0.183)\end{array}$ & $\begin{array}{c}0.349 * * \\
(0.171)\end{array}$ \\
\hline Constant & $\begin{array}{c}0.034 \\
(0.501)\end{array}$ & $\begin{array}{c}-2.571 * * * \\
(0.542)\end{array}$ & $\begin{array}{c}-6.574 * * * \\
(0.244)\end{array}$ & $\begin{array}{c}-3.095 * * * \\
(0.608)\end{array}$ \\
\hline Number of observations & 2,060 & 2,060 & 2,060 & 2,060 \\
\hline
\end{tabular}

Notes: Coefficient estimates of random effects logit models are shown with standard errors in parentheses. $*, * *, * * *$ significant at the $10 \%, 5 \%$, and $1 \%$ level, respectively. 
Table A. 9 Determinants of participation in off-farm activities (multivariate probit model)

\begin{tabular}{|c|c|c|c|c|}
\hline \multirow[b]{2}{*}{ Variables } & \multicolumn{3}{|c|}{ Employed activities } & \multirow[b]{2}{*}{ Self-employed } \\
\hline & Agriculture & Manufacturing & Services & \\
\hline \multirow[t]{2}{*}{ Oil palm adoption (dummy) } & 0.023 & 0.019 & -0.004 & $0.144 * *$ \\
\hline & $(0.072)$ & $(0.078)$ & $(0.071)$ & $(0.065)$ \\
\hline \multirow[t]{2}{*}{ Farm size (land cultivated in ha) } & $-0.090 * * *$ & $-0.013 * *$ & $-0.011 * *$ & $0.013 * * *$ \\
\hline & $(0.012)$ & $(0.007)$ & $(0.005)$ & $(0.004)$ \\
\hline \multirow[t]{2}{*}{ Female-headed household (dummy) } & -0.087 & $0.308 * *$ & $0.327 * *$ & -0.103 \\
\hline & $(0.136)$ & $(0.140)$ & $(0.134)$ & $(0.134)$ \\
\hline \multirow[t]{2}{*}{ Household size } & $0.106 * * *$ & $0.074 * * *$ & $0.131 * * *$ & $0.053 * * *$ \\
\hline & $(0.021)$ & $(0.023)$ & $(0.021)$ & $(0.020)$ \\
\hline \multirow[t]{2}{*}{ Age of household head (years) } & $-0.019 * * *$ & $-0.007 *$ & $0.013 * * *$ & -0.002 \\
\hline & $(0.003)$ & $(0.003)$ & $(0.003)$ & $(0.003)$ \\
\hline \multirow[t]{2}{*}{ Education of household head (years) } & $-0.050 * * *$ & 0.010 & $0.095 * * *$ & 0.005 \\
\hline & $(0.010)$ & $(0.011)$ & $(0.010)$ & $(0.009)$ \\
\hline \multirow[t]{2}{*}{ Migrant household (dummy) } & $0.119^{*}$ & -0.028 & -0.064 & $-0.166^{* *}$ \\
\hline & $(0.068)$ & $(0.075)$ & $(0.069)$ & $(0.065)$ \\
\hline \multirow[t]{2}{*}{ Access to credit (dummy) } & 0.056 & -0.032 & 0.039 & $0.407 * * *$ \\
\hline & $(0.074)$ & $(0.081)$ & $(0.074)$ & $(0.067)$ \\
\hline \multirow[t]{2}{*}{ Non-random village (dummy) } & $0.190 *$ & $-0.296 * *$ & 0.142 & 0.060 \\
\hline & $(0.098)$ & $(0.122)$ & $(0.098)$ & $(0.093)$ \\
\hline \multirow[t]{2}{*}{ Distance to market $(\mathrm{km})$} & -0.001 & 0.007 & $0.016^{* * *}$ & -0.005 \\
\hline & $(0.005)$ & $(0.006)$ & $(0.005)$ & $(0.005)$ \\
\hline \multirow[t]{2}{*}{ Survey round 2015 (dummy) } & 0.113 & $0.375 * * *$ & 0.029 & $0.176 * *$ \\
\hline & $(0.080)$ & $(0.085)$ & $(0.088)$ & $(0.076)$ \\
\hline \multirow[t]{2}{*}{ Survey round 2018 (dummy) } & $0.156^{*}$ & -0.150 & $0.496 * * *$ & $0.134 *$ \\
\hline & $(0.082)$ & $(0.096)$ & $(0.084)$ & $(0.078)$ \\
\hline \multirow[t]{2}{*}{ Constant } & 0.191 & $-1.247 * * *$ & $-3.143 * * *$ & $-1.134 * * *$ \\
\hline & $(0.219)$ & $(0.241)$ & $(0.234)$ & $(0.210)$ \\
\hline Number of observations & 2,060 & 2,060 & 2,060 & 2,060 \\
\hline
\end{tabular}

Notes: Coefficient estimates of a multivariate probit model are shown with standard errors in parentheses. $*, * *, * * *$ significant at the $10 \%, 5 \%$, and $1 \%$ level, respectively. 


\section{Appendix of Chapter 4}

Table A. 10 Household nutrition and health expenditure by oil palm adoption status and survey year

\begin{tabular}{|c|c|c|c|c|c|c|}
\hline \multirow[t]{2}{*}{ Variables } & \multicolumn{3}{|c|}{ Oil palm adopters } & \multicolumn{3}{|c|}{ Non-adopters } \\
\hline & 2012 & 2015 & 2018 & 2012 & 2015 & 2018 \\
\hline Average farm size (ha) & $\begin{array}{c}6.673 \\
(9.666)\end{array}$ & $\begin{array}{c}6.623 \\
(9.541)\end{array}$ & $\begin{array}{c}6.613 \\
(9.073)\end{array}$ & $\begin{array}{l}3.948 \\
(6.044)\end{array}$ & $\begin{array}{c}4.022 \\
(6.652)\end{array}$ & $\begin{array}{l}3.265 \\
(3.720)\end{array}$ \\
\hline $\begin{array}{l}\text { Total household expenditure (million } \\
\text { IDR/AE/year) }\end{array}$ & $\begin{array}{l}15.717 \\
(10.266)\end{array}$ & $\begin{array}{c}15.126 \\
(10.771)\end{array}$ & $\begin{array}{l}15.338 \\
(14.691)\end{array}$ & $\begin{array}{l}11.963 \\
(8.184)\end{array}$ & $\begin{array}{l}11.176 \\
(7.300)\end{array}$ & $\begin{array}{l}11.387 \\
(9.164)\end{array}$ \\
\hline Dietary diversity score $(0-9)$ & $\begin{array}{c}6.929 \\
(1.101)\end{array}$ & $\begin{array}{c}6.964 \\
(1.144)\end{array}$ & $\begin{array}{c}6.921 \\
(1.152)\end{array}$ & $\begin{array}{c}6.552 \\
(1.246)\end{array}$ & $\begin{array}{c}6.555 \\
(1.282)\end{array}$ & $\begin{array}{c}6.660 \\
(1.214)\end{array}$ \\
\hline Calories (kcal/AE/day) & $\begin{array}{c}3416.343 \\
(1757.298)\end{array}$ & $\begin{array}{c}3101.858 \\
(1572.149)\end{array}$ & $\begin{array}{c}3559.030 \\
(1485.528)\end{array}$ & $\begin{array}{c}2917.594 \\
(1419.927)\end{array}$ & $\begin{array}{c}2611.110 \\
(1122.198)\end{array}$ & $\begin{array}{c}3275.209 \\
(1453.924)\end{array}$ \\
\hline $\begin{array}{l}\text { Household food expenditure (million } \\
\text { IDR/AE/year) }\end{array}$ & $\begin{array}{c}8.545 \\
(4.662)\end{array}$ & $\begin{array}{c}7.660 \\
(4.279)\end{array}$ & $\begin{array}{c}7.517 \\
(4.182)\end{array}$ & $\begin{array}{l}7.172 \\
(3.752)\end{array}$ & $\begin{array}{c}6.254 \\
(3.164)\end{array}$ & $\begin{array}{c}6.392 \\
(3.278)\end{array}$ \\
\hline $\begin{array}{l}\text { Share of food expenditure (\% of total } \\
\text { expenditure) }\end{array}$ & $\begin{array}{c}0.587 \\
(0.161)\end{array}$ & $\begin{array}{c}0.560 \\
(0.155)\end{array}$ & $\begin{array}{c}0.571 \\
(0.178)\end{array}$ & $\begin{array}{c}0.631 \\
(0.135)\end{array}$ & $\begin{array}{c}0.602 \\
(0.150)\end{array}$ & $\begin{array}{c}0.618 \\
(0.151)\end{array}$ \\
\hline $\begin{array}{l}\text { Total health expenditure ('000 } \\
\text { IDR/AE/year) }\end{array}$ & $\begin{array}{c}369.182 \\
(2070.627)\end{array}$ & $\begin{array}{c}440.685 \\
(2239.743)\end{array}$ & $\begin{array}{c}243.383 \\
(742.847)\end{array}$ & $\begin{array}{c}216.491 \\
(1011.218)\end{array}$ & $\begin{array}{c}336.420 \\
(2006.793)\end{array}$ & $\begin{array}{c}182.806 \\
(705.499)\end{array}$ \\
\hline Hospital expenditure ('000 IDR/AE/year) & $\begin{array}{c}291.147 \\
(2044.043)\end{array}$ & $\begin{array}{c}322.326 \\
(2127.000)\end{array}$ & $\begin{array}{c}149.609 \\
(662.474)\end{array}$ & $\begin{array}{c}166.369 \\
(987.100)\end{array}$ & $\begin{array}{c}257.136 \\
(1970.025)\end{array}$ & $\begin{array}{c}116.355 \\
(676.544)\end{array}$ \\
\hline $\begin{array}{l}\text { Community health center expenditure } \\
\text { ('000 IDR/AE/year) }\end{array}$ & $\begin{array}{l}16.669 \\
(60.802)\end{array}$ & $\begin{array}{c}7.565 \\
(34.790)\end{array}$ & $\begin{array}{c}16.997 \\
(186.956)\end{array}$ & $\begin{array}{c}14.166 \\
(38.096)\end{array}$ & $\begin{array}{c}7.664 \\
(42.995)\end{array}$ & $\begin{array}{c}7.621 \\
(34.486)\end{array}$ \\
\hline $\begin{array}{l}\text { Doctor's practice expenditure ('000 } \\
\text { IDR/AE/year) }\end{array}$ & $\begin{array}{c}16.103 \\
(77.848)\end{array}$ & $\begin{array}{c}28.920 \\
(182.021)\end{array}$ & $\begin{array}{c}16.549 \\
(80.171)\end{array}$ & $\begin{array}{c}18.056 \\
(134.088)\end{array}$ & $\begin{array}{c}32.552 \\
(254.341)\end{array}$ & $\begin{array}{c}10.341 \\
(54.833)\end{array}$ \\
\hline $\begin{array}{l}\text { Traditional healer expenditure ('000 } \\
\text { IDR/AE/year) }\end{array}$ & $\begin{array}{c}2.483 \\
(17.934)\end{array}$ & $\begin{array}{c}10.836 \\
(37.739)\end{array}$ & $\begin{array}{c}8.700 \\
(30.311)\end{array}$ & $\begin{array}{c}1.600 \\
(10.382)\end{array}$ & $\begin{array}{c}14.450 \\
(111.576)\end{array}$ & $\begin{array}{c}11.551 \\
(57.446)\end{array}$ \\
\hline $\begin{array}{l}\text { Medicine expenditure ('000 } \\
\text { IDR/AE/year) }\end{array}$ & $\begin{array}{c}42.780 \\
(331.349)\end{array}$ & $\begin{array}{c}71.039 \\
(539.338)\end{array}$ & $\begin{array}{c}51.528 \\
(177.238)\end{array}$ & $\begin{array}{c}16.300 \\
(58.225)\end{array}$ & $\begin{array}{c}24.618 \\
(116.134)\end{array}$ & $\begin{array}{c}36.938 \\
(120.516)\end{array}$ \\
\hline Number of observations & 240 & 249 & 318 & 444 & 438 & 371 \\
\hline
\end{tabular}

Notes: Mean values for the 2012, 2015, and 2018 survey rounds, are shown with standard deviations in parentheses. Monetary values in 2015 and 2018 were deflated to 2012 values to allow comparison across survey rounds. Total household expenditure, household food expenditure, and health-related expenditure were deflated using the consumer price index, food price index, and medical care price index for Jambi, respectively. In 2012, 1 US\$ was equivalent to IDR 9,670. AE, adult equivalent. 
Table A. 11 Household education by oil palm adoption status and survey year

\begin{tabular}{|c|c|c|c|c|c|c|}
\hline \multirow{2}{*}{ Education variables } & \multicolumn{3}{|c|}{ Oil palm adopters } & \multicolumn{3}{|c|}{ Non-adopters } \\
\hline & 2012 & 2015 & 2018 & 2012 & 2015 & 2018 \\
\hline Children's school enrollment (\%) & $\begin{array}{c}0.994 \\
(0.078)\end{array}$ & $\begin{array}{c}0.996 \\
(0.043)\end{array}$ & $\begin{array}{c}0.997 \\
(0.036)\end{array}$ & $\begin{array}{c}0.994 \\
(0.063)\end{array}$ & $\begin{array}{c}0.988 \\
(0.106)\end{array}$ & $\begin{array}{c}0.990 \\
(0.036)\end{array}$ \\
\hline Children's school dropout rates $(\%)$ & $\begin{array}{c}0.101 \\
(0.275)\end{array}$ & $\begin{array}{c}0.140 \\
(0.309)\end{array}$ & $\begin{array}{c}0.114 \\
(0.296)\end{array}$ & $\begin{array}{c}0.117 \\
(0.282)\end{array}$ & $\begin{array}{c}0.164 \\
(0.347)\end{array}$ & $\begin{array}{c}0.141 \\
(0.331)\end{array}$ \\
\hline $\begin{array}{l}\text { Household education expenditure ('000 } \\
\text { IDR/AE/year) }\end{array}$ & $\begin{array}{c}366.271 \\
(1126.076)\end{array}$ & $\begin{array}{c}138.190 \\
(350.592)\end{array}$ & $\begin{array}{c}310.036 \\
(1227.792)\end{array}$ & $\begin{array}{c}157.499 \\
(663.635)\end{array}$ & $\begin{array}{c}129.015 \\
(385.844)\end{array}$ & $\begin{array}{c}80.415 \\
(191.002)\end{array}$ \\
\hline Number of observations & 164 & 167 & 198 & 303 & 287 & 227 \\
\hline Girls' school enrollment (\%) & $\begin{array}{c}0.990 \\
(0.102)\end{array}$ & $\begin{array}{c}0.988 \\
(0.102)\end{array}$ & $\begin{array}{c}0.992 \\
(0.089)\end{array}$ & $\begin{array}{c}0.992 \\
(0.082)\end{array}$ & $\begin{array}{c}0.994 \\
(0.078)\end{array}$ & $\begin{array}{c}1.000 \\
(0.000)\end{array}$ \\
\hline Girls' school dropout rates $(\%)$ & $\begin{array}{c}0.082 \\
(0.267)\end{array}$ & $\begin{array}{c}0.143 \\
(0.332)\end{array}$ & $\begin{array}{c}0.114 \\
(0.310)\end{array}$ & $\begin{array}{c}0.102 \\
(0.289)\end{array}$ & $\begin{array}{c}0.160 \\
(0.354)\end{array}$ & $\begin{array}{c}0.115 \\
(0.308)\end{array}$ \\
\hline Number of observations & 97 & 107 & 126 & 187 & 166 & 129 \\
\hline Boys' school enrollment (\%) & $\begin{array}{c}1.000 \\
(0.000)\end{array}$ & $\begin{array}{c}1.000 \\
(0.000)\end{array}$ & $\begin{array}{c}1.000 \\
(0.000)\end{array}$ & $\begin{array}{c}0.995 \\
(0.073)\end{array}$ & $\begin{array}{c}0.981 \\
(0.131)\end{array}$ & $\begin{array}{c}0.978 \\
(0.146)\end{array}$ \\
\hline Boys' school dropout rates (\%) & $\begin{array}{c}0.105 \\
(0.283)\end{array}$ & $\begin{array}{c}0.146 \\
(0.338)\end{array}$ & $\begin{array}{c}0.117 \\
(0.316)\end{array}$ & $\begin{array}{c}0.159 \\
(0.338)\end{array}$ & $\begin{array}{c}0.182 \\
(0.374)\end{array}$ & $\begin{array}{c}0.155 \\
(0.360)\end{array}$ \\
\hline Number of observations & 102 & 106 & 111 & 190 & 179 & 139 \\
\hline $\begin{array}{l}\text { Total out-remittance ('000 } \\
\text { IDR/AE/year) }\end{array}$ & $\begin{array}{c}3202.083 \\
(14346.660)\end{array}$ & $\begin{array}{c}309.068 \\
(989.686)\end{array}$ & $\begin{array}{c}358.992 \\
(2272.968)\end{array}$ & $\begin{array}{c}1351.599 \\
(5079.234)\end{array}$ & $\begin{array}{c}207.528 \\
(901.283)\end{array}$ & $\begin{array}{c}113.455 \\
(634.704)\end{array}$ \\
\hline Number of observations & 240 & 249 & 318 & 444 & 438 & 371 \\
\hline
\end{tabular}

Notes: Mean values for the 2012, 2015, and 2018 survey rounds, are shown with standard deviations in parentheses. Some number of observations are lower than total samples because only households with school-aged children, girls, or boys are included. Monetary values in 2015 and 2018 were deflated to 2012 values to allow comparison across survey rounds. Household education expenditure and total out-remittance were deflated using the education price index and consumer price index for Jambi, respectively. In 2012, 1 US\$ was equivalent to IDR 9,670. AE, adult equivalent. 
Table A. 12 Household electricity and communication expenditure by oil palm adoption status and survey year

\begin{tabular}{lcccccc}
\hline \multirow{2}{*}{ Variables } & \multicolumn{3}{c}{ Oil palm adopters } & \multicolumn{3}{c}{ Non-adopters } \\
\cline { 2 - 7 } & $\mathbf{2 0 1 2}$ & $\mathbf{2 0 1 5}$ & $\mathbf{2 0 1 8}$ & $\mathbf{2 0 1 2}$ & $\mathbf{2 0 1 5}$ & $\mathbf{2 0 1 8}$ \\
\hline Electricity expenditure ('000 & 43.537 & 45.937 & 50.345 & 36.248 & 35.233 & 42.217 \\
IDR/AE/year) & $(43.749)$ & $(31.441)$ & $(35.120)$ & $(30.193)$ & $(25.937)$ & $(57.404)$ \\
Communication expenditure ('000 & 24.238 & 15.422 & 22.234 & 17.676 & 12.168 & 17.357 \\
IDR/AE/year) & $(30.392)$ & $(21.151)$ & $(24.101)$ & $(24.405)$ & $(22.002)$ & $(22.513)$ \\
Number of observations & 240 & 249 & 318 & 444 & 438 & 371
\end{tabular}

Notes: Mean values for the 2012, 2015, and 2018 survey rounds, are shown with standard deviations in parentheses. Monetary values in 2015 and 2018 were deflated to 2012 values to allow comparison across survey rounds. Electricity expenditure and communication expenditure were deflated using the electricity price index and communication price index for Jambi, respectively. In 2012, 1 US\$ was equivalent to IDR 9,670. AE, adult equivalent 


\section{Farm household survey questionnaire}

\section{CRC 990: "Determinants of land use change and impact on household welfare among smallholder farmers" University of Göttingen - University of Jambi -IPB}

Household survey questionnaire

(Farm survey; round 3; 2018)

1. Household identification

\begin{tabular}{|c|c|c|c|}
\hline 1. Village (name): & & & \\
\hline 2. Dusun (name or number): & & & \\
\hline 3. RT (number): & & & \\
\hline 4. Household code (given by supervisor): & & & \\
\hline 5. Name of the current household head: & & & \\
\hline 6. Name of the current respondent: & & & \\
\hline $\begin{array}{l}\text { 7. Was the household interviewed in 2015? (If } \\
\text { no, go to question 14) }\end{array}$ & & Yes/No & \\
\hline 8. Name of household head in 2015 : & & & \\
\hline 9. Did the household head change since 2015? & & Yes/No & \\
\hline 10. Name of respondent in 2015: & & & \\
\hline 11. Did the respondent change since 2015 ? & & Yes/No & \\
\hline 12. Why did the respondent change? (Code A) & & & \\
\hline $\begin{array}{l}\text { 13. Did the household change place of } \\
\text { residence after 2015? }\end{array}$ & & Yes/No & \\
\hline 14. GPS co-ordinates of the household & 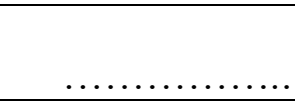 & $S ; \ldots \ldots \ldots \ldots \ldots \ldots \ldots$ & ............Alt \\
\hline 15. Mobile phone numbers: & $\begin{array}{l}\text { Primary: } \\
\text { Secondary: } \\
\text { Tertiary: }\end{array}$ & & \\
\hline $\begin{array}{l}\text { 16. Distance from the household's dwelling to } \\
\text { the nearest market / trading center }(\mathrm{km})\end{array}$ & & & \\
\hline $\begin{array}{l}\text { 17. Household interviewed by other sub- } \\
\text { projects? }\end{array}$ & C01: Yes / No & B09: Yes / No & CP: Yes / NO \\
\hline 18. Interviewer (name): & & & \\
\hline 19. Supervisor (name): & & & \\
\hline 20. Date of interview: & ...../....//2018 & Enumerator's signature: & \\
\hline $\begin{array}{l}\text { 21. Date questionnaire was checked by } \\
\text { supervisor: }\end{array}$ & ...../ ...../ 2018 & Supervisor's signature: & \\
\hline
\end{tabular}

Code A: currently out of village $=1$; moved out of the household $=2$; passed away $=3$; others (specify) $=4$. 


\section{General farm data}

\subsection{Cropping activities}

What kind of crops are you currently growing on your farm:

\begin{tabular}{|c|c|c|c|c|c|}
\hline & \multicolumn{2}{|c|}{$\begin{array}{l}\text { Area under cultivation } \\
\text { (ha) }\end{array}$} & \multicolumn{2}{|c|}{$\begin{array}{c}\text { For how much of this land } \\
\text { (ha), you have }\end{array}$} & \multirow{2}{*}{$\begin{array}{c}\text { The certificate } \\
\text { is under whose } \\
\text { name? } \\
\text { (1=Male; } \\
2=\text { Female; } \\
3=\text { Both) }\end{array}$} \\
\hline & In 2015 & In 2018 & $\begin{array}{l}\text { Systematic } \\
\text { certificate }\end{array}$ & $\begin{array}{l}\text { Sporadic } \\
\text { certificate }\end{array}$ & \\
\hline \multicolumn{6}{|l|}{ 1. Oil palm (total) } \\
\hline a. Oil palm (independent) & & & & & \\
\hline b. Oil palm (under contract) & & & & & \\
\hline $\begin{array}{ll}2 . & \begin{array}{l}\text { Plantation and jungle rubber } \\
\text { (total) }\end{array}\end{array}$ & & & & & \\
\hline $\begin{array}{l}\text { a. Plantation and jungle rubber } \\
\text { (independent) }\end{array}$ & & & & & \\
\hline $\begin{array}{l}\text { b. Plantation and jungle rubber } \\
\text { (under contract) }\end{array}$ & & & & & \\
\hline 3. Other plantation crops 1: & & & & & \\
\hline 4. Other plantation crops 2: & & & & & \\
\hline 5. Other plantation crops 3: & & & & & \\
\hline 6. Homestead and kitchen garden & & & & & \\
\hline 7. Rice & & & & & \\
\hline 8. Other annual crop 1: & & & & & \\
\hline 9. Other annual crop 2: & & & & & \\
\hline 10. Other annual crop 3: & & & & & \\
\hline $\begin{array}{l}\text { 11.Fallow land (no cultivation in } \\
\text { last } 12 \text { months) }\end{array}$ & & & & & \\
\hline
\end{tabular}

\subsection{Land ownership and management}

\begin{tabular}{|l|l|l|}
\hline $\begin{array}{l}\text { 1a. In the last } 12 \text { months, did you own } \\
\text { any land, which is cultivated by some } \\
\text { other household? (e. g. sharecropping as } \\
\text { landlord) }\end{array}$ & \multirow{2}{*}{ Yes/No } & If yes, under output sharing?......... Yes/No \\
\cline { 3 - 3 } & & $\begin{array}{l}\text { If yes, share of harvest received as rent:............\% } \\
\text { Size of land under output sharing:.......... ha }\end{array}$ \\
\cline { 3 - 3 } (Land should be included in table 2.1) & $\begin{array}{l}\text { If no, rent you received for renting out:...........Rp '000/ha/year } \\
\text { Size of land under rent arrangements:........ ha }\end{array}$ \\
\hline
\end{tabular}




\begin{tabular}{|c|c|c|}
\hline \multirow{3}{*}{$\begin{array}{l}\text { 1b. In the last } 12 \text { months, did you own } \\
\text { any land, which is cultivated by a } \\
\text { company? }\end{array}$} & \multirow{3}{*}{ Yes/No } & If yes: \\
\hline & & Size of such land: .......... ha \\
\hline & & Rent you received for renting out:........... '000/ha/year. \\
\hline \multirow{4}{*}{$\begin{array}{l}\text { 2. In the last } 12 \text { months, did you cultivate } \\
\text { any land together with another farmer or } \\
\text { group of farmers or co-operative society? } \\
\text { (Collective farming) }\end{array}$} & \multirow{4}{*}{ Yes/No } & If yes: \\
\hline & & Total land under this arrangement:........ ha \\
\hline & & $\begin{array}{l}\text { How much of the land you own is under this arrangement? ...... } \\
\text { ha }\end{array}$ \\
\hline & & No. of farmers in the group: ........... \\
\hline \multirow{2}{*}{$\begin{array}{l}\text { 3a. In the last } 12 \text { months, did you cultivate } \\
\text { any land, owned by others? (e.g. } \\
\text { sharecropping as tenant) }\end{array}$} & \multirow{3}{*}{ Yes/No } & If yes, under output sharing?.......... Yes/No \\
\hline & & $\begin{array}{l}\text { If yes, share of harvest received as wage:..........\% } \\
\text { Size of land under output sharing:......... ha }\end{array}$ \\
\hline (Land should not be included in table 2.1) & & 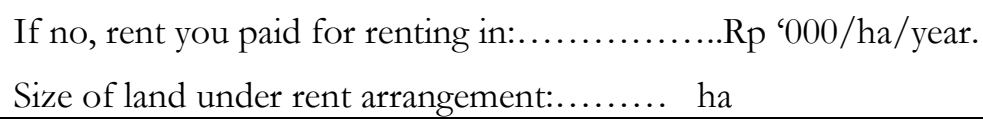 \\
\hline
\end{tabular}

\section{History of crop cultivation}

\subsection{Migration (ONLY FOR NEWLY ADDED FARMERS, OTHERWISE CONTINUE TO 3.2)}

a. Did the household migrate from somewhere to this village? ....... (Yes/No) (If no, go to 3.2).

b. If yes, did the household migrate as part of transmigrant programme? ............. (Yes/No)

c. If yes, the crop associated with transmigrant programme: Oil palm/ Rubber/Others (specify):........

Details of starting of cultivation and contract for transmigrant households:

\begin{tabular}{|c|c|c|c|}
\hline \multicolumn{4}{|c|}{ 1. When did the household migrate to the village? (Year) } \\
\hline \multicolumn{3}{|c|}{ 2. Who was the head of the household at the time of migration? (Code A) } & \\
\hline & \multicolumn{2}{|c|}{$\begin{array}{l}\text { If you were not the head of household at time of migration, age of the household head at } \\
\text { that time (Years) }\end{array}$} & \\
\hline & \multicolumn{2}{|c|}{ The place from where the household migrated to this village? (Code B) } & \\
\hline \multicolumn{3}{|c|}{ 5. What was the major source of income for the household before migration? (Code C) } & \\
\hline \multicolumn{3}{|c|}{ 6. What was your household size before migration? (number of household members) } & \\
\hline \multicolumn{3}{|c|}{ 7. How many of your family members.... (number) } & \\
\hline & \multicolumn{2}{|c|}{ a. Came to this village in your group of migration? (including respondent) } & \\
\hline & \multicolumn{2}{|c|}{ b. Arrived in this village after you came? (exclude the members born here) } & \\
\hline & \multicolumn{2}{|c|}{ Was there a house already built for you in this village (e.g. by the government)? } & Yes / No \\
\hline \multirow{3}{*}{\multicolumn{2}{|c|}{$\begin{array}{l}\text { What was the size of land provided by } \\
\text { government as part of the transmigrant } \\
\text { programme? }\end{array}$}} & a. Plantation (ha) & \\
\hline & & b. Food crops (ha) & \\
\hline & & c. Housing $\left(\mathrm{m}^{2}\right)$ & \\
\hline
\end{tabular}

Code A: current $\mathrm{HH}$ head $=1$, father $/$ mother of current $\mathrm{HH}$ head $=2$; grandparent of current $\mathrm{HH}$ head $=3$; brother $/$ sister of current $\mathrm{HH}$ head $=4$; other $($ specify $)=5$

Code B: Other part of Jambi $=1$; Java $=2$; North Sumatra $=3$; South Sumatra $=4$; Kalimantan $=5$; Sulawesi $=6$; others (specify) $=7$

Code C: crops $=1$; fisheries and livestock $=2$; wage labour $=3$; small business $=4$; others (specify) $=5$ 
3.2. Household details at plantation start (Do not include the crop covered under transmigrant programme. But if a transmigrant household started another crop later, that information should be included in this table.)

\begin{tabular}{|c|c|c|}
\hline & Oil palm & $\begin{array}{l}\text { Plantation or } \\
\text { jungle rubber }\end{array}$ \\
\hline 1. Have you ever cultivated the crop? (If no, go to next column) & Yes / No & Yes / No \\
\hline $\begin{array}{l}\text { a. Was the household already interviewed in 2015? (If no, go to question } \\
\text { 2) }\end{array}$ & Yes / No & Yes / No \\
\hline $\begin{array}{l}\text { b. Have you started cultivating the crop after 2015? (If no, go to next } \\
\text { column) }\end{array}$ & Yes / No & Yes / No \\
\hline 2. When did the household start cultivating the crop? (Year) & & \\
\hline $\begin{array}{l}\text { 3. Which of your family members first started the cultivation/ obtained the } \\
\text { plantation? (Code A) (If Code } A=1 \text { go to question 5) }\end{array}$ & & \\
\hline $\begin{array}{l}\text { 4. If some other household member (and not the current head) started the } \\
\text { plantation, then: }\end{array}$ & & \\
\hline a. Relation of that member with the current household head (Code B) & & \\
\hline b. Age of this member at starting of the estate (Years) & & \\
\hline c. Gender of this household member $($ male $=0$, female $=1$ ) & & \\
\hline d. Education of this member when the estate was started (Years in school): & & \\
\hline e. Was he/she residing in this village for all his/her life? & Yes / No & Yes / No \\
\hline f. If no, when did he/she migrate to this village (Year) & & \\
\hline 5. Was the whole estate planted by the household? (If yes, go to question 6) & Yes / No & Yes / No \\
\hline a. Size of the estate that was not established by household (ha) & & \\
\hline b. Number of oil palm / rubber trees already existing in that field & & \\
\hline c. What was the average age of trees? (years) & & \\
\hline 6. Before the plantation was started, & & \\
\hline $\begin{array}{l}\text { a. How many adult family members were there in your household } \\
\text { (number)? }\end{array}$ & & \\
\hline b. How much land did your household have under cultivation? (ha) & & \\
\hline c. For how much of this land did your household have a land title? (ha) & & \\
\hline d. Were any of your relatives already cultivating the crop? & Yes / No & Yes / No \\
\hline $\begin{array}{l}\text { e. How many of the other farmer households in your neighborhood/RT } \\
\text { started the cultivation before you? (number) }\end{array}$ & & \\
\hline $\begin{array}{l}\text { 7. Total number of households in the neighborhood/ RT at that point of } \\
\text { time? }\end{array}$ & & \\
\hline & $\begin{array}{l}\text { Please go to } \\
\text { next } \\
\text { column }\end{array}$ & $\begin{array}{l}\text { Please go to } \\
\text { next table }\end{array}$ \\
\hline
\end{tabular}

Code A: current $\mathrm{HH}$ head $=1$; previous $\mathrm{HH}$ head $=2$; acquired through marriage $=3$; others (specify) $=4$

Code B: father $/$ mother $=1$; grandparent $=2$; brother $=3$; in-laws $=4$; others $($ specify) $=5$ 


\subsection{Oil palm}

- If the farmer ever cultivated oil palm (If not, go to 3.4.):

a. Area under oil palm in 2015:........... ha

b. How many hectares do you have today? ha

- If newly added farmer:

c. With how many hectares did you start cultivation? ha

d. How many times was the area under this crop changed from the start of cultivation until today? ......

- If the farmer was already interviewed in 2015 :

e. How many times the area under the crop was changed after 2015 until today? .........times (if 0 , go to 3.4)

Details of changes (changes after 2015 for farmers interviewed in 2015; all changes for newly added farmers):

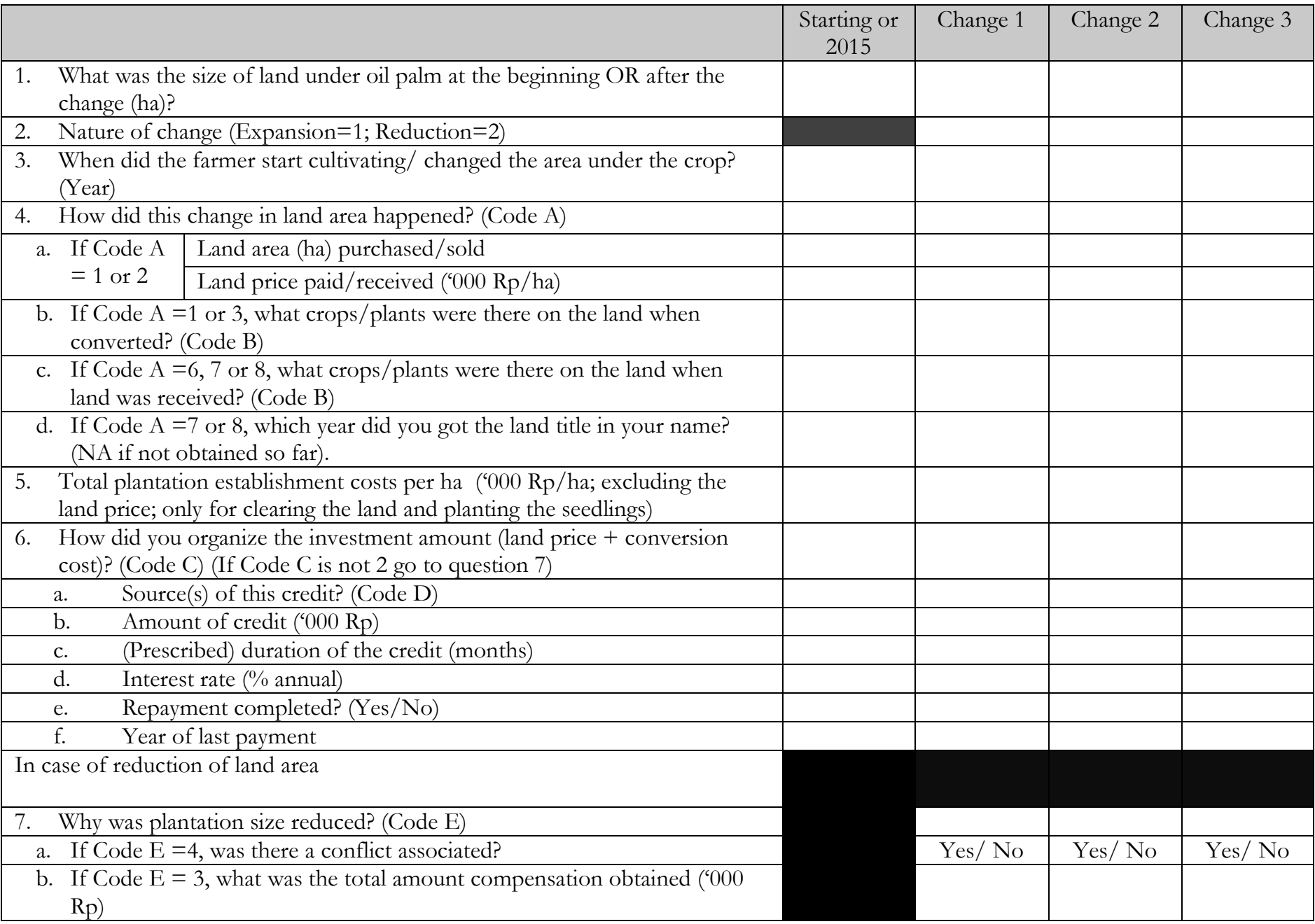

Code A: purchasing $=1$; selling $=2$; converted from $/$ to other crops $=3$; conversion from forest $=4$; obtained as part of a government programme (e.g." "transmigransi") $=5$; established plantation obtained from company $=6$; inherited $=7$; received as gift $=8$; others $($ specify $)=9$

Code B: oil palm $=1$; plantation rubber $=2$; jungle rubber $=3$; other plantation $=4$; annual crops $($ specify $)=5$; grassland $=6$; forest $=7$; bush $=8$; others $($ specify $)=9$

Code C: savings $=1 ;$ credit $=2 ;$ parents $/$ spouse $=3$; no need to pay at the beginning $=4$; others $($ specify $)=5$

Code D: banks $=1$; private company $=2$; money lender $=3$; friends relatives $=4$; farmer cooperative $=5$; other farmers $=6$; others (specify) $=7$

Code E: land sold $=1$; land contracted out to other family $=2$; land submitted to a company $=3$; land lost without compensation $=4$; land given away to other family member or relative $=5$; other (specify) $=6$ 


\subsection{Plantation and Jungle Rubber}

- If the farmer ever cultivated rubber (If not, go to 3.5.):

a. Area under rubber in $2015: \ldots \ldots \ldots \ldots$ ha

b. How many hectares do you have today? ha

- If newly added farmer:

c. With how many hectares did you start cultivation? ha

d. How many times was the area under this crop changed from the start of cultivation until today? ......

- If the farmer was already interviewed in 2015:

e. How many times the area under the crop was changed after 2015 until today? .........times (if 0 , go to 3.5)

Details of changes (changes after 2015 for farmers interviewed in 2015; all changes for newly added farmers):

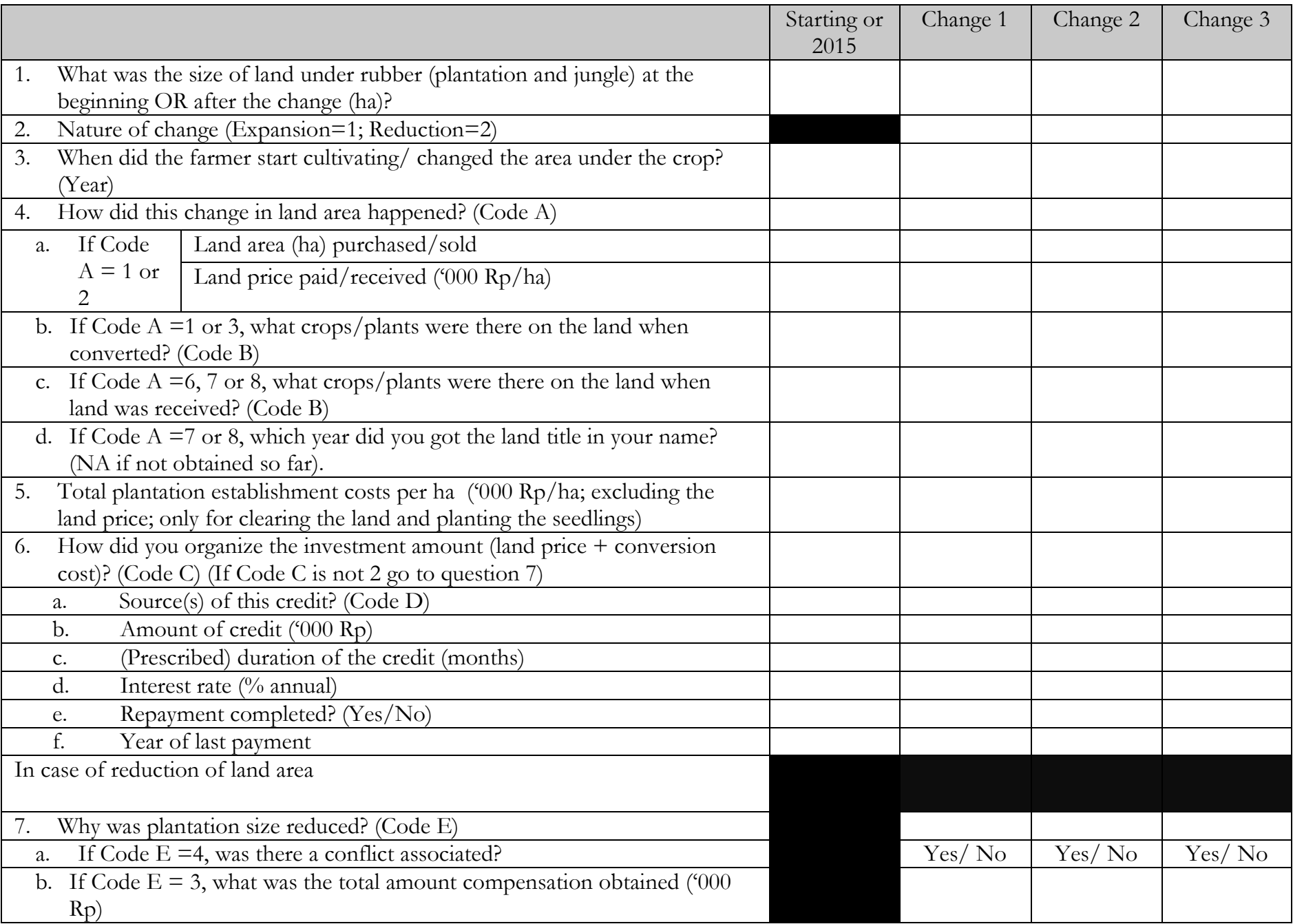

Code A: purchasing = 1; selling $=2$; converted from $/$ to other crops $=3$; conversion from forest $=4$; obtained as part of a government program (e.g. "transmigransi") $=5$; established plantation obtained from company $=6$; inherited $=7$; received as gift $=8$; others (specify) $=9$

Code B: oil palm $=1$; plantation rubber $=2$; jungle rubber $=3$; other plantation $=4$; annual crops (specify) $=5$; grassland $=6$; forest $=7$; bush $=8$; others (specify) $=9$

Code C: savings $=1 ;$ credit $=2$; parents $/$ spouse $=3 ;$ no need to pay at the beginning $=4$; others $($ specify $)=5$

Code D: banks $=1$; private company $=2$; money lender $=3$; friends $/$ relatives $=4$; farmer cooperative $=5$; other farmers $=6$; others (specify) $=7$

Code E: land sold=1; land contracted out to other family $=2$; land submitted to a company $=3$; land lost without compensation=4; land given away to other family member or relative $=5$; other (specify) $=6$ 
4. Cost of cultivation of all crops cultivated during the last 12 months (including the kitchen garden)

a. How many permanent laborers are employed on your farm? ....................... (number)

b. Wages paid per month: ............... ('000 Rp/month)

\begin{tabular}{|c|c|c|c|c|c|c|c|c|c|c|c|}
\hline \multirow{2}{*}{\multicolumn{2}{|c|}{ Crop name }} & \multicolumn{5}{|c|}{ Perennials } & \multicolumn{4}{|c|}{ Annuals } & \multirow{2}{*}{$\begin{array}{l}\text { Home- } \\
\text { stead } \\
\text { and } \\
\text { kitchen } \\
\text { garden }\end{array}$} \\
\hline & & Oil palm & $\begin{array}{l}\text { Rubber } \\
\text { (plantation } \\
+ \text { jungle) }\end{array}$ & $\begin{array}{c}\text { Other } \\
1\end{array}$ & $\begin{array}{l}\text { Other } \\
2\end{array}$ & $\begin{array}{l}\text { Other } \\
3\end{array}$ & $\begin{array}{c}\text { Crop } \\
1\end{array}$ & $\begin{array}{l}\text { Crop } \\
2\end{array}$ & $\begin{array}{l}\text { Crop } \\
3\end{array}$ & Crop & \\
\hline \multicolumn{12}{|l|}{$\begin{array}{l}\text { 1. Name of the main crop (if an annual crop is cultivated in more } \\
\text { than one season, consider it as an additional crop) }\end{array}$} \\
\hline \multicolumn{12}{|l|}{ 3. Total area under cultivation under this crop (ha) } \\
\hline \multicolumn{12}{|l|}{ 4. Area under production (ha) } \\
\hline \multicolumn{12}{|l|}{ 5. Area under share-cropping (ha) } \\
\hline \multicolumn{12}{|l|}{ 6. If yes, which share does the farmer receive? } \\
\hline \multicolumn{2}{|l|}{ 7. Do you intercrop the plots? (If no, go to question 13) } & $\begin{array}{l}\text { Yes/ } \\
\text { No }\end{array}$ & $\begin{array}{l}\text { Yes/ } \\
\text { No }\end{array}$ & $\begin{array}{l}\text { Yes/ } \\
\text { No }\end{array}$ & $\begin{array}{l}\text { Yes/ } \\
\text { No }\end{array}$ & $\begin{array}{l}\text { Yes/ } \\
\text { No }\end{array}$ & $\begin{array}{l}\text { Yes/ } \\
\text { No }\end{array}$ & $\begin{array}{l}\text { Yes/ } \\
\text { No }\end{array}$ & $\begin{array}{l}\text { Yes/ } \\
\text { No }\end{array}$ & $\begin{array}{l}\text { Yes/ } \\
\text { No }\end{array}$ & \\
\hline \multicolumn{12}{|l|}{$\begin{array}{l}\text { 8. If yes, number of intercrops (report number of types of crops in } \\
\text { homestead and kitchen farm) }\end{array}$} \\
\hline \multicolumn{12}{|l|}{ 9. Area under intercropping (ha) } \\
\hline \multirow{3}{*}{$\begin{array}{l}\text { 10. Names of major intercrops (different plants/trees in case of } \\
\text { homestead farming) }\end{array}$} & 1 & & & & & & & & & & \\
\hline & 2 & & & & & & & & & & \\
\hline & 3 & & & & & & & & & & \\
\hline \multicolumn{12}{|l|}{ 11. Intercrop 1} \\
\hline \multicolumn{12}{|l|}{ a. Number of harvests during last 12 months } \\
\hline \multicolumn{12}{|l|}{ b. Quantity $(\mathrm{kg})$ produced during last 12 months } \\
\hline \multicolumn{12}{|l|}{ c. Quantity $(\mathrm{kg})$ marketed } \\
\hline \multirow{2}{*}{\multicolumn{12}{|c|}{$\begin{array}{l}\text { d. Avg. price received during last } 12 \text { months (' } 000 \mathrm{Rp} / \mathrm{kg} \text { ) } \\
\text { 12. Intercrop } 2\end{array}$}} \\
\hline & & & & & & & & & & & \\
\hline \multicolumn{12}{|l|}{ a. Number of harvests during last 12 months } \\
\hline \multicolumn{12}{|l|}{ b. Quantity $(\mathrm{kg})$ produced during last 12 months } \\
\hline \multicolumn{12}{|l|}{ c. Quantity $(\mathrm{kg})$ marketed } \\
\hline d. Avg. price received during last 12 months ('000 Rp/kg) & & & & & & & & & & & \\
\hline \multicolumn{2}{|l|}{ Crop name } & \multicolumn{5}{|c|}{ Perennials } & \multicolumn{4}{|c|}{ Annuals } & \\
\hline
\end{tabular}




\begin{tabular}{|c|c|c|c|c|c|c|c|c|c|c|}
\hline & Oil palm & $\begin{array}{l}\text { Rubber } \\
\text { (plantation } \\
+ \text { jungle) }\end{array}$ & $\begin{array}{c}\text { Other } \\
1\end{array}$ & $\begin{array}{l}\text { Other } \\
2\end{array}$ & $\begin{array}{c}\text { Other } \\
3\end{array}$ & $\begin{array}{l}\text { Crop } \\
1\end{array}$ & $\begin{array}{l}\text { Crop } \\
2\end{array}$ & $\begin{array}{l}\text { Crop } \\
3\end{array}$ & $\begin{array}{c}\text { Crop } \\
4\end{array}$ & $\begin{array}{l}\text { Home- } \\
\text { stead } \\
\text { and } \\
\text { Kitchen } \\
\text { garden }\end{array}$ \\
\hline \multicolumn{11}{|l|}{ 13. Intercrop 3} \\
\hline a. Number of harvests during last 12 months & & & & & & & & & & \\
\hline b. Quantity (kg) produced during last 12 months & & & & & & & & & & \\
\hline c. Quantity (kg) marketed & & & & & & & & & & \\
\hline d. Avg. price received during last 12 months ('000 Rp/kg) & & & & & & & & & & \\
\hline \multicolumn{11}{|l|}{ 14. Main Crop } \\
\hline a. Number of harvests during last 12 months & & & & & & & & & & \\
\hline b. Quantity (kg) produced during last 12 months & & & & & & & & & & \\
\hline c. Quantity (kg) marketed & & & & & & & & & & \\
\hline d. Avg. price received during last 12 months ('000 Rp/kg) & & & & & & & & & & \\
\hline \multicolumn{11}{|l|}{$\begin{array}{l}\text { 15. Quantity of inputs applied for the crop plots (quantity/season for } \\
\text { annuals and quantity/year for perennials) for all main and inter- } \\
\text { crops in last } 12 \text { months* }\end{array}$} \\
\hline a. Seeds/Seedlings ('000 Rp spent by household) & & & & & & & & & & \\
\hline b. Manures ('000 Rp spent by household) & & & & & & & & & & \\
\hline c. $\quad$ Chemical fertilizers ('000 Rp spent by household) & & & & & & & & & & \\
\hline d. Pesticides ('000 Rp spent by household) & & & & & & & & & & \\
\hline e. $\quad$ Herbicides ('000 Rp spent by household) & & & & & & & & & & \\
\hline $\begin{array}{l}\text { f. Hired male and female labour on daily basis ('000 Rp spent } \\
\text { by household) }\end{array}$ & & & & & & & & & & \\
\hline g. $\quad$ Hired animal/machine labour ('000 Rp. spent by household) & & & & & & & & & & \\
\hline \multicolumn{11}{|l|}{$\begin{array}{l}\text { 16. Which household members are more involved in crop } \\
\text { management and decisions, like selecting varieties, choosing } \\
\text { fertilizers etc. (Code A) }\end{array}$} \\
\hline $\begin{array}{l}\text { 17. Which household members are more involved in deciding the use } \\
\text { of income generated? (Code A) }\end{array}$ & & & & & & & & & & \\
\hline
\end{tabular}

Code A: 1=Male; $2=$ Female; $3=$ Both

* Remember that we are not asking for the total cost of inputs/labour used for the crop, but the actual amount spent by the household for the crop. In case of sharecropping, these two values may differ 
5. Plantation crops: Plot endowment and production relations (Only OIL PALM / RUBBER)

5.1. General plot information [A plot is defined as a piece of land under one crop, which is not segmented spatially and where the managerial practices are common and palms/trees are of approximately same age. Complete one column before going to the next.]. How many plots do you own?.

\begin{tabular}{|c|c|c|c|c|}
\hline & Research plot 1 & Plot 2 (C01/B09) & Plot 3 & Plot 4 \\
\hline \multicolumn{5}{|l|}{ 1. Area of plot (ha) } \\
\hline \multicolumn{5}{|l|}{ 2. Number of palms/trees in the plot } \\
\hline \multicolumn{5}{|l|}{ 3. Number of productive palms/trees in the plot } \\
\hline 4. Do you intercrop the plot? & Yes/No & Yes/No & Yes/No & Yes/No \\
\hline 5. Ownership of land: Owned/Leased-in & Own/Lsd-in & Own/Lsd-in & Own/Lsd-in & Own/Lsd-in \\
\hline 6. Are you employing sharecropping tenants in this plot? (If no, go to question 7) & Yes/No & Yes/No & Yes/No & Yes/No \\
\hline a. If yes, how many of farm households are involved? (number) & & & & \\
\hline \multicolumn{5}{|l|}{ b. When did this sharecropping arrangement start for this plot? (year) } \\
\hline c. Does the sharecropping tenant belong to your ethnic group? & Yes/No & Yes/No & Yes/No & Yes/No \\
\hline d. Is the sharecropping tenant your close relative? & Yes/No & Yes/No & Yes/No & Yes/No \\
\hline e. Did you sign a written agreement before starting the sharecropping? & Yes/No & Yes/No & Yes/No & Yes/No \\
\hline \multicolumn{5}{|l|}{ f. Input cost $(\%)$ provided by your household } \\
\hline \multicolumn{5}{|l|}{ g. Share of output $(\%)$ provided as wage } \\
\hline h. Did the share of output provided as wage increase over last 3 years? & Yes/No & Yes/No & Yes/No & Yes/No \\
\hline i. If applicable, was the drop in rubber price the main reason for the increase? & Yes/No & Yes/No & Yes/No & Yes/No \\
\hline 7. Who is currently managing the plot? (Code A) (If Code A is 1 go to question 9) & & & & \\
\hline \multirow{2}{*}{\multicolumn{5}{|c|}{$\begin{array}{l}\text { 8. If entrusted someone else (e.g. plantation company, other farmer etc.): } \\
\text { a. Monthly costs paid by household ('000 Rp.) }\end{array}$}} \\
\hline & & & & \\
\hline b. Monthly revenues obtained by household ('000 Rp.) & & & & \\
\hline
\end{tabular}




\begin{tabular}{|c|c|c|c|c|}
\hline & Research plot 1 & Plot 2 (C01/B09) & Plot 3 & Plot 4 \\
\hline \multicolumn{5}{|l|}{$\begin{array}{l}\text { 9. Is there a land title (certificate) for this land in your (or some other household member's) } \\
\text { name, at present? (Code B) (If none go to question 10) }\end{array}$} \\
\hline $\begin{array}{l}\text { a. If there is a land title or certificate in your (or some other household member's) name, } \\
\text { do you have it with you at present (and not with other person/ institution, e.g. a } \\
\text { credit institution)? }\end{array}$ & Yes/No & Yes/No & Yes/No & Yes/No \\
\hline \multicolumn{5}{|l|}{$\begin{array}{l}\text { b. Was there a land title (certificate) for this plot when you obtained the land? } \\
\text { (Code B) }\end{array}$} \\
\hline 10. Was the plot purchased? (Ask only if new plots are aquired after 2015) & Yes/No & Yes/No & Yes/No & Yes/No \\
\hline a. If yes, year of purchase? & & & & \\
\hline b. If yes, from whom was the plot purchased? (Code C) & & & & \\
\hline c. What was the reason of the household for selling the land? (Code D) & & & & \\
\hline $\begin{array}{l}\text { 11. Was this plot self-established (that is, the household did not obtain an estate } \\
\text { established by someone else)? (If no go to question 13) }\end{array}$ & Yes/No & Yes/No & Yes/No & Yes/No \\
\hline \multicolumn{5}{|l|}{ 12. In case of self-establishment; year of establishment? } \\
\hline \multirow{2}{*}{\multicolumn{5}{|c|}{$\begin{array}{l}\text { 13. In case plot was not established by the household, how did you acquire the plot? } \\
\text { (Code E) } \\
\text { 14. If at least part of the estate was not established by the household }\end{array}$}} \\
\hline & & & & \\
\hline a. Year of procurement/purchase & & & & \\
\hline b. Number of palms/trees already existing in the plot & & & & \\
\hline c. Age of palms/trees at the time of procurement & & & & \\
\hline \multicolumn{5}{|l|}{ 15. Year of first harvest ever } \\
\hline \multicolumn{5}{|l|}{ 16. Year of last replanting in the plot (put NA if never replanted). } \\
\hline \multicolumn{5}{|l|}{$\begin{array}{l}\text { 17. If replanted, year of first harvest after replanting (if harvesting is not started, } \\
\text { indicate expected year of first harvest) }\end{array}$} \\
\hline 18. Varieties grown $(1=$ Improved; $0=$ Local $)$ & & & & \\
\hline
\end{tabular}




\begin{tabular}{|c|c|c|c|c|}
\hline & Research plot 1 & Plot 2 (C01/B09) & Plot 3 & Plot 4 \\
\hline \multicolumn{5}{|l|}{ 19. Distance from the plot to: } \\
\hline \multicolumn{5}{|l|}{ Home (meters) } \\
\hline \multicolumn{5}{|l|}{ Nearest road (meters) } \\
\hline \multicolumn{5}{|l|}{ Nearest village center (meters) } \\
\hline $\begin{array}{l}\text { 20. Have you noticed any land grabbing or land expropriation from any farmers by } \\
\text { government, other farmers, plantation company near this plot? }\end{array}$ & Yes/No & Yes/No & Yes/No & Yes/No \\
\hline \multicolumn{5}{|l|}{$\begin{array}{l}\text { If yes, the year of occurance of this event(s). A time period may be given (e.g., } \\
\text { 1998-2001) if the event is occurring over time }\end{array}$} \\
\hline $\begin{array}{l}\text { 21. Have you ever used an animal/insect/any living being to control a crop pest } \\
\text { (including weeds) or disease? }\end{array}$ & Yes/No & Yes/No & Yes/No & Yes/No \\
\hline 22. Do you ever used fire to clear the plot? & Yes/ No & Yes/ No & Yes/ No & Yes/ No \\
\hline \multicolumn{5}{|l|}{ 23. If yes, in which year? } \\
\hline 24. Do you keep the cut-off plants and crop residues on the plot? & Yes/ No & Yes/ No & Yes/ No & Yes/ No \\
\hline \multicolumn{5}{|l|}{ 25. How do you rate your soil fertility $($ High $=2 ;$ Medium $=1 ;$ Low $=0)$} \\
\hline \multicolumn{5}{|l|}{$\begin{array}{l}\text { 26. What is the color of the soil? }(\text { Black }=1 \text {; Red }=2 \text {; White } / \text { Light }=3 \text {; Yellow }=4 \text {; } \\
\text { Other }=5 \text { ) }\end{array}$} \\
\hline \multicolumn{5}{|l|}{$\begin{array}{l}\text { 27. What is the texture of the soil? (Very fine }=1 \text {; Fine }=2 ; \text { Between coarse and fine }=3 \text {; } \\
\text { Coarse }=4 ; \text { Very coarse }=5 \text { ) }\end{array}$} \\
\hline 28. Were there any problems with erosion in the last agricultural season? & Yes/ No & Yes/ No & Yes/ No & Yes/ No \\
\hline $\begin{array}{l}\text { 29. What were the causes for the erosion? (Wind }=1 \text {; Rain }=2 \text {; Animals }=3 \text {; Cultivation } \\
\text { which does not comply with soil conservation=4; Other }=5 \text { ) }\end{array}$ & & & & \\
\hline $\begin{array}{l}\text { Code A: household }=1 ; \text { entrusted to company }=2 ; \text { entrusted to farmer cooperative }=3 ; \text { o } \\
\text { Code B: Yes, Systematic Certificate }=1 ; \text { Yes, Sporadic certificate }=2 ; \text { Yes, Letter from vill } \\
\text { Code C: migrant household }=1 ; \text { transmigrant household }=2 ; \text { autochonous household }=3 \text {. } \\
\text { Code D: Financial needs }=1 ; \text { Migration }=2 ; \text { Unproductive land }=3 \text {, Other } \text { (specifiy) }=4 . \\
\text { Code E: transmigrant programme }=1 ; \text { other government programme }=2 ; \text { purchased from }\end{array}$ & $\begin{array}{l}\text { armer }=4 ; \text { others }= \\
\text { ead or Segal }=3 ; \mathrm{N}\end{array}$ & $\begin{array}{l}\text { (specify) } \\
e=4\end{array}$ & & \\
\hline
\end{tabular}


5.2. Product marketing: All productive plots of the crop

a. Number of times output was sold during the last 12 months:..................... (number)

b. Through how many outlets the output was sold during last 12 months:.

(number)

c. During the last 12 months, from how many traders can you choose one for selling output: (maximum number)

\begin{tabular}{|c|c|c|c|c|c|c|}
\hline \multirow{2}{*}{$\begin{array}{l}\text { Outlets where the } \\
\text { output was sold in } \\
\text { last } 12 \text { months } \\
\text { (name) }\end{array}$} & \multirow{2}{*}{$\begin{array}{c}\text { Type of outlet } \\
\text { (Code A) }\end{array}$} & \multirow{2}{*}{$\begin{array}{l}\text { Do you have } \\
\text { a contract } \\
\text { relation with } \\
\text { outlet? }\end{array}$} & \multirow{2}{*}{$\begin{array}{l}\% \text { of output sold } \\
\text { through this outlet } \\
\text { during the last } 12 \\
\text { months }\end{array}$} & \multicolumn{3}{|c|}{ Product transport to the outlet point } \\
\hline & & & & $\begin{array}{c}\text { in } \mathrm{km} \\
(0 \text { if purchased } \\
\text { at farm-gate) }\end{array}$ & $\begin{array}{l}\text { mode of } \\
\text { transportation } \\
\text { (Code } \mathrm{B})\end{array}$ & $\begin{array}{c}\text { time taken for } \\
\text { transportation } \\
\text { (hours) }\end{array}$ \\
\hline 1. & & Yes/No & & & & \\
\hline 2. & & Yes/ No & & & & \\
\hline 3. & & Yes/ No & & & & \\
\hline 4. & & Yes/ No & & & & \\
\hline 5. & & Yes/No & & & & \\
\hline 6. & & Yes/ No & & & & \\
\hline
\end{tabular}

Code A: private plantation $=1$; government plantation $=2$; private trader in village $=3$; private trader outside village $=4$; farmer group or cooperative $=5$; others (specify) $=6$

Code B: farm-gate selling $=0 ;$ walking $=1 ;$ cycle $=2$; ojek $=3$; angkot $=4$; bus $=5$; truck $=6$; tractor $=7$; others $($ specify $)=8$ 
6. Plot identification

a. Did the farmer start to cultivate the crop after 2015 or is newly added?............(Yes/No) [If farmer started to cultivate the crop after 2015 or the farmer is newly added use additional pages to report information on all new plots in chapter 6.1; 6.2 and 6.3 and proceed to section 6.1]

b.

c. Please let the farmer identify the plots with the data provided from all his plots.

Research Plot: Size:....... ha; Age of plantation:....... years; Distance from home:..........m

Additional C01/B09/Research Plot: Size:....... ha; Age of plantation:....... years; Distance from home:...........m

Additional C01/B09/Research Plot: Size:....... ha; Age of plantation:....... years; Distance from home:...........m

Other Plot: Size:....... ha; Age of plantation:....... years; Distance from home:..........m

Other Plot: Size:....... ha; Age of plantation:...... years; Distance from home:...........

Other Plot:: Size:....... ha; Age of plantation:....... years; Distance from home:...........m

Other Plot:: Size:....... ha; Age of plantation:....... years; Distance from home:...........m

Other Plot:: Size:....... ha; Age of plantation:....... years; Distance from home:...........m

a. Did the farmer clearly identify the research plot? .........(Yes/No)

b. If applicable, did the farmer clearly identify the additional C01/B09/Research plot? ..........(Yes/No)

c. If applicable, did the farmer clearly identify the additional C01/B09/Research plot? ..........(Yes/No) 
6.1. Input use during last 12 months: Research plot (Report only data from the identified research plot)

\begin{tabular}{|c|c|c|c|c|c|}
\hline Inputs in research plot & $\begin{array}{l}\text { 1. Name of } \\
\text { input }\end{array}$ & $\begin{array}{l}\text { 2. Number } \\
\text { of times } \\
\text { used }\end{array}$ & $\begin{array}{l}\text { 3. Unit of } \\
\text { measurement }\end{array}$ & $\begin{array}{l}\text { 5. Quantity used } \\
\text { (QU/plot/year) (report } \\
\text { in total and not per } \\
\text { times) }\end{array}$ & $\begin{array}{l}\text { 6. Average price of input as } \\
\text { used during last } 12 \text { months } \\
\text { ('000 Rp/Unit) }\end{array}$ \\
\hline 1. Seedlings (I planting)* & & & Number & & \\
\hline 2. Seedlings (replanting)* & & & Number & & \\
\hline 3. Manure: Plant waste & & & $\mathrm{kg}$ & & \\
\hline 4. Manure: Animal waste & & & $\mathrm{kg}$ & & \\
\hline \multirow[t]{5}{*}{ 6. Chemical fertilizers } & & & $\mathrm{kg}$ & & \\
\hline & & & $\mathrm{kg}$ & & \\
\hline & & & $\mathrm{kg}$ & & \\
\hline & & & $\mathrm{kg}$ & & \\
\hline & & & $\mathrm{kg}$ & & \\
\hline 7. Herbicides & & & litres & & \\
\hline 9. Irrigation (excl. labour cost) & & & ‘000 Rp & & \\
\hline 10. Machinery & & & '000 Rp / liter & & \\
\hline 11. Input transport & & & '000 Rp / liter & & \\
\hline 12. Output transport & & & '000 Rp / liter & & \\
\hline $\begin{array}{l}\text { 13. Materials for output processing } \\
\text { in rubber }\end{array}$ & & & '000 Rp & & \\
\hline 14. Others (specify) & & & ‘000 Rp & & \\
\hline
\end{tabular}


6.2. Labor use during last 12 months: Research plot

\begin{tabular}{|c|c|c|c|c|c|c|c|c|c|c|c|c|c|}
\hline \multirow[t]{2}{*}{$\begin{array}{l}\text { Labour use in research } \\
\text { plot }\end{array}$} & \multicolumn{2}{|c|}{ 1.a Rainy season } & \multicolumn{2}{|c|}{ 1.b Dry season } & \multirow[t]{2}{*}{$\begin{array}{c}2 . \\
\text { Average } \\
\text { working } \\
\text { hours } \\
\text { per day }\end{array}$} & \multirow[t]{2}{*}{$\begin{array}{c}3 . \\
\text { Contracted } \\
\text { out the } \\
\text { operation? } \\
\text { Yes }=1 / \\
\text { No }=0)\end{array}$} & \multirow[t]{2}{*}{$\begin{array}{c}\text { 4. If } \\
\text { contracted } \\
\text { out, cost of } \\
\text { operation } \\
\text { ('000 Rp) }\end{array}$} & \multicolumn{2}{|c|}{$\begin{array}{c}\text { 5. If not } \\
\text { contracted out, } \\
\text { hired laborers/ } \\
\text { operation } \\
\text { (number) }\end{array}$} & \multicolumn{2}{|c|}{$\begin{array}{c}\text { 6. Wage rate } \\
\text { ('000 Rp/worker } \\
\text { day) } \\
\text { (put sc if } \\
\text { sharecropping) }\end{array}$} & \multicolumn{2}{|c|}{$\begin{array}{c}\text { 7. Family } \\
\text { members } \\
\text { involved/ } \\
\text { operation (Give } \\
\text { Member IDs) }\end{array}$} \\
\hline & $\begin{array}{c}\text { \# of } \\
\text { opera } \\
\text {-tions }\end{array}$ & \begin{tabular}{|c|} 
Days \\
per \\
operation
\end{tabular} & $\begin{array}{l}\text { \# of } \\
\text { opera } \\
\text {-tions }\end{array}$ & $\begin{array}{c}\text { Days } \\
\text { per } \\
\text { operation }\end{array}$ & & & & Men & Women & Men & Women & Men & Women \\
\hline 1. Land clearing for planting & & & & & & & & & & & & & \\
\hline 2. Other pre-planting activitic & & & & & & & & & & & & & \\
\hline 3. Taking pits for planting & & & & & & & & & & & & & \\
\hline 4. Seedling transportation & & & & & & & & & & & & & \\
\hline 5. Planting & & & & & & & & & & & & & \\
\hline 6. Replanting & & & & & & & & & & & & & \\
\hline 7. Manure application & & & & & & & & & & & & & \\
\hline 8. Fertilizer application & & & & & & & & & & & & & \\
\hline $\begin{array}{l}\text { 9. Chemical weeding on the } \\
\text { ground }\end{array}$ & & & & & & & & & & & & & \\
\hline $\begin{array}{l}\text { 10. Manual weeding on the } \\
\text { ground }\end{array}$ & & & & & & & & & & & & & \\
\hline 12. Manual weeding on trees & & & & & & & & & & & & & \\
\hline 13. Chemical weeding on trees & & & & & & & & & & & & & \\
\hline 14. Pesticide application & & & & & & & & & & & & & \\
\hline 16. Irrigation & & & & & & & & & & & & & \\
\hline $\begin{array}{l}\text { 17. Intercultural operations } \\
\text { (esp. for soil improvement }\end{array}$ & & & & & & & & & & & & & \\
\hline 18. Tapping (only for rubber) & & & & & & & & & & & & & \\
\hline 19. Harvesting & & & & & & & & & & & & & \\
\hline 20. Processing of product & & & & & & & & & & & & & \\
\hline 21. Transportation to market & & & & & & & & & & & & & \\
\hline 22. Marketing & & & & & & & & & & & & & \\
\hline 23. Cutting leaves of oil palm & & & & & & & & & & & & & \\
\hline 24. Others (specify) & & & & & & & & & & & & & \\
\hline
\end{tabular}


6.3 Average harvested quantity in the last 12 months: Research plot

\begin{tabular}{|l|c|c|c|}
\hline Season of year & $\begin{array}{c}\text { 1. Frequency of } \\
\text { harvests (once in } \\
\text { how many days?) }\end{array}$ & $\begin{array}{c}\text { 2. Quantity harvested } \\
\text { per month from this } \\
\text { plot (kg/plot) }\end{array}$ & $\begin{array}{c}\text { 3. Average price obtained for } \\
\text { output in that season } \\
\text { ('000 Rp/kg) }\end{array}$ \\
\hline 1. Dry season (June to November) & & & \\
\hline 2. Rainy season (December to May) & & & \\
\hline
\end{tabular}

\section{Risk and Shock events}

7.1. Shock events during the last 3 years: For all plots and crops and livestock

a. Did you suffer from any shocks (e.g. drought, flood, pest) concerning your agricultural activities during the last three years? (Yes/No) (If no, go to next table)

\begin{tabular}{|c|c|c|c|c|c|}
\hline & $\begin{array}{l}\text { 1. Did the } \\
\text { specific } \\
\text { shock occur } \\
\text { in the last } \\
\text { three years? }\end{array}$ & $\begin{array}{l}\text { 2. Year and } \\
\text { month of } \\
\text { the shock } \\
\text { event's start } \\
\text { (MM.YYYY) }\end{array}$ & $\begin{array}{l}\text { 3. Year and } \\
\text { month of } \\
\text { the shock } \\
\text { event's end } \\
\text { (MM.YYY } \\
\text { Y) }\end{array}$ & $\begin{array}{l}\text { 4. Which plots } \\
\text { were affected? } \\
\text { (Code A) } \\
\text { (Multiple } \\
\text { answers } \\
\text { possible) }\end{array}$ & $\begin{array}{l}5 . \text { How much of } \\
\text { your total harvest/ } \\
\text { livestock did you } \\
\text { lose in total over } \\
\text { the whole shock } \\
\text { period? }(\%)\end{array}$ \\
\hline 1. Drought & Yes/No & & & & \\
\hline 2. Too much rain (Flood) & Yes/No & & & & \\
\hline 3. Late rain & Yes/No & & & & \\
\hline 4. Fire & Yes/No & & & & \\
\hline $\begin{array}{l}\text { 5. Theft (Eg: Livestock or } \\
\text { crops) }\end{array}$ & Yes/No & & & & \\
\hline 6. Crop pest/disease & Yes/No & & & & \\
\hline 7. Livestock disease & Yes/No & & & & \\
\hline $\begin{array}{l}\text { 8. Critical illness or demise of } \\
\text { HH members }\end{array}$ & Yes/No & & & & \\
\hline 9. Other................ & Yes/No & & & & \\
\hline
\end{tabular}

Code A: Main plot reported for oil palm = 1; Main plot reported for rubber $=2$; Additionally reported core $/ \mathrm{C} 01 / \mathrm{B} 09$ plot = 3 ; Other plot $=4$.

\subsection{Risk and time preferences}

1) Are you generally a person who is fully prepared to take risks or do you try to avoid taking risk? (Please choose a number on a scale from 0 to 10 )

\begin{tabular}{|l|l|l|l|l|l|l|l|l|l|l|}
\hline 0 & 1 & 2 & 3 & 4 & 5 & 6 & 7 & 8 & 9 & 10 \\
\hline
\end{tabular}

$0=$ unwilling to take risks

$10=$ fully prepared to take risk

2) Are you generally a person who is fully prepared to give up something now in order to gain more in the future?

\begin{tabular}{|l|l|l|l|l|l|l|l|l|l|l|}
\hline 0 & 1 & 2 & 3 & 4 & 5 & 6 & 7 & 8 & 9 & 10 \\
\hline
\end{tabular}


8. Forest dependent activities (Include all the timber and non-timber products your household collects or used to collect)

\begin{tabular}{|c|c|c|c|c|c|c|c|c|c|c|c|}
\hline \multirow[t]{2}{*}{$\begin{array}{l}\text { 1. Forest } \\
\text { product } \\
\text { collected }\end{array}$} & \multirow{2}{*}{$\begin{array}{l}\text { 2. How } \\
\text { often do } \\
\text { you collect } \\
\text { it or do it? } \\
\text { (Once in } \\
\text { how many } \\
\text { days) }\end{array}$} & \multirow{2}{*}{$\begin{array}{l}\text { 3. How } \\
\text { many } \\
\text { members of } \\
\text { your HH } \\
\text { are involved } \\
\text { in collection } \\
\text { (number) }\end{array}$} & \multirow{2}{*}{$\begin{array}{l}\text { 3.a Which } \\
\text { household } \\
\text { members are } \\
\text { more } \\
\text { involved in } \\
\text { this activity? } \\
\text { (Code A) }\end{array}$} & \multirow{2}{*}{$\begin{array}{l}\text { 4. How } \\
\text { many other } \\
\text { households } \\
\text { are involved } \\
\text { in this } \\
\text { activity? } \\
\text { (number) }\end{array}$} & \multicolumn{2}{|c|}{$\begin{array}{l}\text { 5. Quantity } \\
\text { obtained during } \\
\text { last } 12 \text { months }\end{array}$} & \multicolumn{2}{|c|}{$\begin{array}{l}\text { 6. Quantity sold } \\
\text { during last } 12 \\
\text { months }\end{array}$} & \multirow{2}{*}{$\begin{array}{l}\text { 7. Average } \\
\text { price } \\
\text { obtained } \\
(000 \\
\text { Rp/Unit) } \\
\text { during last } \\
12 \text { months }\end{array}$} & \multirow{2}{*}{$\begin{array}{l}\text { 8. Share of } \\
\text { revenue }(\%) \\
\text { for your } \\
\text { household if } \\
\text { more than } 1 \\
\text { households } \\
\text { are involved }\end{array}$} & \multirow{2}{*}{$\begin{array}{l}\text { 9. Which } \\
\text { household } \\
\text { members are } \\
\text { more involved } \\
\text { in deciding the } \\
\text { use of income } \\
\text { generated? } \\
\text { (Code A) }\end{array}$} \\
\hline & & & & & $\begin{array}{c}\text { a. } \\
\text { Quantity }\end{array}$ & $\begin{array}{c}\text { b. } \\
\text { Unit }\end{array}$ & $\begin{array}{c}\text { a. } \\
\text { Quantit } \\
y\end{array}$ & $\begin{array}{c}\text { b. } \\
\text { Unit }\end{array}$ & & & \\
\hline \multicolumn{12}{|l|}{ Timber } \\
\hline \multicolumn{12}{|l|}{ Honey } \\
\hline \multicolumn{12}{|l|}{ Firewood } \\
\hline \multicolumn{12}{|l|}{$\begin{array}{l}\text { Hunting birds } \\
\text { in forest }\end{array}$} \\
\hline \multicolumn{12}{|l|}{ Other hunting } \\
\hline Other:. & & & & & & & & & & & \\
\hline
\end{tabular}

Code A: $1=$ Male; $2=$ Female; $3=$ Both 


\section{Livestock production}

\section{a. Animals possessed and produced by the household during the last 12 months}

\begin{tabular}{|c|c|c|c|c|}
\hline & $\begin{array}{l}\text { Cow/Buffalo/ } \\
\text { Bullock }\end{array}$ & $\begin{array}{l}\text { Goat/ } \\
\text { Sheep }\end{array}$ & Poultry \\
\hline \multicolumn{2}{|c|}{$\begin{array}{l}\text { 1. Did you own any of these livestock in the last } 12 \text { months? (If no, go to } \\
\text { next column or table) }\end{array}$} & Yes/No & Yes/No & Yes/No \\
\hline \multicolumn{5}{|c|}{ 3. How many heads do you own at this point of time? (number) } \\
\hline \multicolumn{5}{|c|}{$\begin{array}{l}\text { 4. If you were to sell all of them today, how much money would you } \\
\text { receive? ('000 Rp) }\end{array}$} \\
\hline \multirow{2}{*}{$\begin{array}{l}\text { 5. If sold in last } \\
12 \text { months }\end{array}$} & a. Number of animals sold & & & \\
\hline & b. Amount obtained in total from sale(s) ('000 Rp) & & & \\
\hline \multirow{3}{*}{$\begin{array}{l}\text { 6. Animals you } \\
\text { consumed as } \\
\text { meat in last } \\
12 \text { months? }\end{array}$} & c. Number of animals/birds & & & \\
\hline & b. Total quantity of meat consumed $(\mathrm{kg})$ & & & \\
\hline & c. Market price of meat ('000 Rp/kg) & & & \\
\hline \multicolumn{5}{|c|}{$\begin{array}{l}\text { 7. How many animals did you give to someone as gift in the last } 12 \\
\text { months? (number) }\end{array}$} \\
\hline \multicolumn{5}{|c|}{ 8. How many died or were lost during the last 12 months? (number) } \\
\hline \multirow{2}{*}{$\begin{array}{l}\text { 9. If purchased } \\
\text { in last } 12 \\
\text { months }\end{array}$} & a. Number of animals purchased & & & \\
\hline & b. Total amount spent for purchasing ('000 Rp) & & & \\
\hline \multicolumn{5}{|c|}{$\begin{array}{l}\text { 10. How many were born on your farm during the last } 12 \text { months? } \\
\text { (number) }\end{array}$} \\
\hline \multicolumn{5}{|c|}{$\begin{array}{l}\text { 11. How many animals did you receive as gift during the last } 12 \text { months? } \\
\text { (number) }\end{array}$} \\
\hline \multicolumn{5}{|c|}{ 12. The main product } \\
\hline \multicolumn{5}{|c|}{ a. Name of the main product } \\
\hline \multicolumn{5}{|c|}{ b. Quantity (Unit) produced during last 12 months } \\
\hline \multicolumn{5}{|c|}{ c. Quantity (Unit) marketed during last 12 months } \\
\hline \multicolumn{5}{|c|}{ d. Avg. price received during last 12 months ('000 Rp/Unit) } \\
\hline \multicolumn{5}{|c|}{ e. Unit (Used for Questions b. c. d.) (e. g. kg, number) } \\
\hline \multicolumn{5}{|l|}{ 13. The byproduct } \\
\hline \multicolumn{5}{|c|}{ a. Name of the byproduct } \\
\hline \multicolumn{5}{|c|}{ b. Quantity (Unit) produced during last 12 months } \\
\hline \multicolumn{5}{|c|}{ c. Quantity (Unit) marketed during last 12 months } \\
\hline \multicolumn{5}{|c|}{ d. Avg. price received during last 12 months ('000 Rp/Unit) } \\
\hline \multicolumn{5}{|c|}{ e. Unit (Used for Questions b. c. d.) (e. g. kg, number) } \\
\hline \multicolumn{5}{|c|}{$\begin{array}{l}\text { 14. Total feed cost during last } 12 \text { months ('000 Rp spent by the } \\
\text { household) }\end{array}$} \\
\hline \multicolumn{5}{|c|}{$\begin{array}{l}\text { 15. Total hired labour cost during last } 12 \text { months ('000 Rp spent by the } \\
\text { household) }\end{array}$} \\
\hline \multicolumn{2}{|c|}{$\begin{array}{l}\text { 16. Total other input cost during last } 12 \text { months ('000 Rp spent by the } \\
\text { household) }\end{array}$} & & & \\
\hline \multicolumn{2}{|c|}{$\begin{array}{l}\text { 17. Which household members are more involved in livestock } \\
\text { management and decisions }(1=\text { Male; } 2=\text { Female; } 3=\text { Both })\end{array}$} & & & \\
\hline \multicolumn{2}{|c|}{$\begin{array}{l}\text { 18. Which household members are more involved in deciding the use of } \\
\text { income generated from livestock production? }(1=\text { Male; } 2=\text { Female; } 3 \\
\text { = Both) }\end{array}$} & & & \\
\hline
\end{tabular}




\section{b. Fish culture during the last 12 months}

\begin{tabular}{|c|c|c|c|}
\hline $\begin{array}{l}\text { 1. Have you been involved in fish culture in the last } 12 \text { months? } \\
\text { (If no, go to next table) }\end{array}$ & \multicolumn{3}{|c|}{ Yes/No } \\
\hline $\begin{array}{l}\text { 3. Number of households involved in fish cultivation (if done } \\
\text { jointly with others)? }\end{array}$ & & & \\
\hline 4. Number of ponds under cultivation & & & \\
\hline \multicolumn{4}{|l|}{ 5. Total size of all fish ponds under cultivation $\left(\mathrm{m}^{2}\right)$} \\
\hline & Fish type 1 & Fish type 2 & Fish type 3 \\
\hline \multicolumn{4}{|l|}{ 6. Name of major fish types being grown } \\
\hline \multicolumn{4}{|l|}{ 7. How many times did you harvest during the last 12 months? } \\
\hline \multicolumn{4}{|l|}{ 8. What is the average quantity of fish obtained per harvest $(\mathrm{kg})$ ? } \\
\hline 9. Did you sell fish? & Yes/No & Yes/No & Yes/No \\
\hline \multicolumn{4}{|l|}{ 10. Amount of fish sold during last 12 months $(\mathrm{kg})$ ? } \\
\hline \multicolumn{4}{|l|}{ 11. If sold, average price obtained ('000 Rp/ $/ \mathrm{kg}$ )? } \\
\hline \multicolumn{4}{|l|}{$\begin{array}{l}\text { 12. How much did you spend on fish feed during the last } 12 \\
\text { months ('000 Rp)? }\end{array}$} \\
\hline \multicolumn{4}{|l|}{$\begin{array}{l}\text { 13. How much did you spend on non-feed materials during the last } \\
12 \text { months ('000 Rp)? }\end{array}$} \\
\hline \multicolumn{4}{|l|}{$\begin{array}{l}\text { 14. How much did you pay for hired labour during last } 12 \text { months } \\
\text { ('000 Rp)? }\end{array}$} \\
\hline \multicolumn{4}{|l|}{$\begin{array}{l}\text { 15. Which household members are more involved in livestock } \\
\text { management and decisions }(1=\text { Male; } 2=\text { Female; } 3=\text { Both })\end{array}$} \\
\hline $\begin{array}{l}\text { 16. Which household members are more involved in deciding the use of } \\
\text { income generated from fish culture? }(1=\text { Male; } 2=\text { Female; } 3= \\
\text { Both })\end{array}$ & & & \\
\hline
\end{tabular}

c. Fishing during the last 12 months

\begin{tabular}{|l|l|}
\hline $\begin{array}{l}\text { 1. } \\
\text { Apart from fish pond cultivation, do you or any of your HH members go } \\
\text { fishing? }\end{array}$ & $\begin{array}{c}\text { Yes/No } \\
\text { (if no, go to next table) }\end{array}$ \\
\hline 2. How many of your HH members go for fishing? (number) & \\
\hline 4. How often do you or your HH members go fishing? (once in .....days) & \\
\hline 5. How much time do you spend on average when you go fishing (hours/day)? & \\
\hline 6. What is the quantity of fish you obtain in an average month? (kg) & \\
\hline 7. What is the quantity of fish you sell in an average month? (kg) & \\
\hline 8. How much money did you receive from fishing in an average month? ('000 & \\
\hline $\begin{array}{l}\text { 9. Which household members involved in management and decision-making in } \\
\text { fishing and fish culture? ( } 1=\text { Male; } 2=\text { Female; } 3=\text { Both) }\end{array}$ & \\
\hline $\begin{array}{l}\text { 10. Which household members are more involved in deciding the use of income } \\
\text { generated from fishing? ( } 1 \text { = Male; } 2=\text { Female; } 3=\text { Both) }\end{array}$ & \\
\hline
\end{tabular}




\section{Credit and Savings}

\subsection{Formal credit institutions}

a. Have you taken or payed back credit during the last 12 months from a bank, farmer group or cooperative?........ (Yes/No)

b. If yes, type of the institute ......... (Code: Bank $=1$; farmer group $=2$; farmer cooperative $=3$, Other $=4$ )

c. If no, what was the main reason for not taking credit?

[Code: Not required or necessary $=1$; Can easily obtain from friends or family $=2$; It is difficult to get $=3$; High interest rate $=4$; No land title to pledge to get credit $=5$; It is morally wrong to take credit $=6$; Others $=7$ (specify: ..)]

d. Who made the decision to borrow? (Code B)

e. Who made the decision about what to do with the money borrowed? (Code B)

If credit was taken or being paid back in the last 12 months from a bank/farmer group/cooperative/other formal groups:

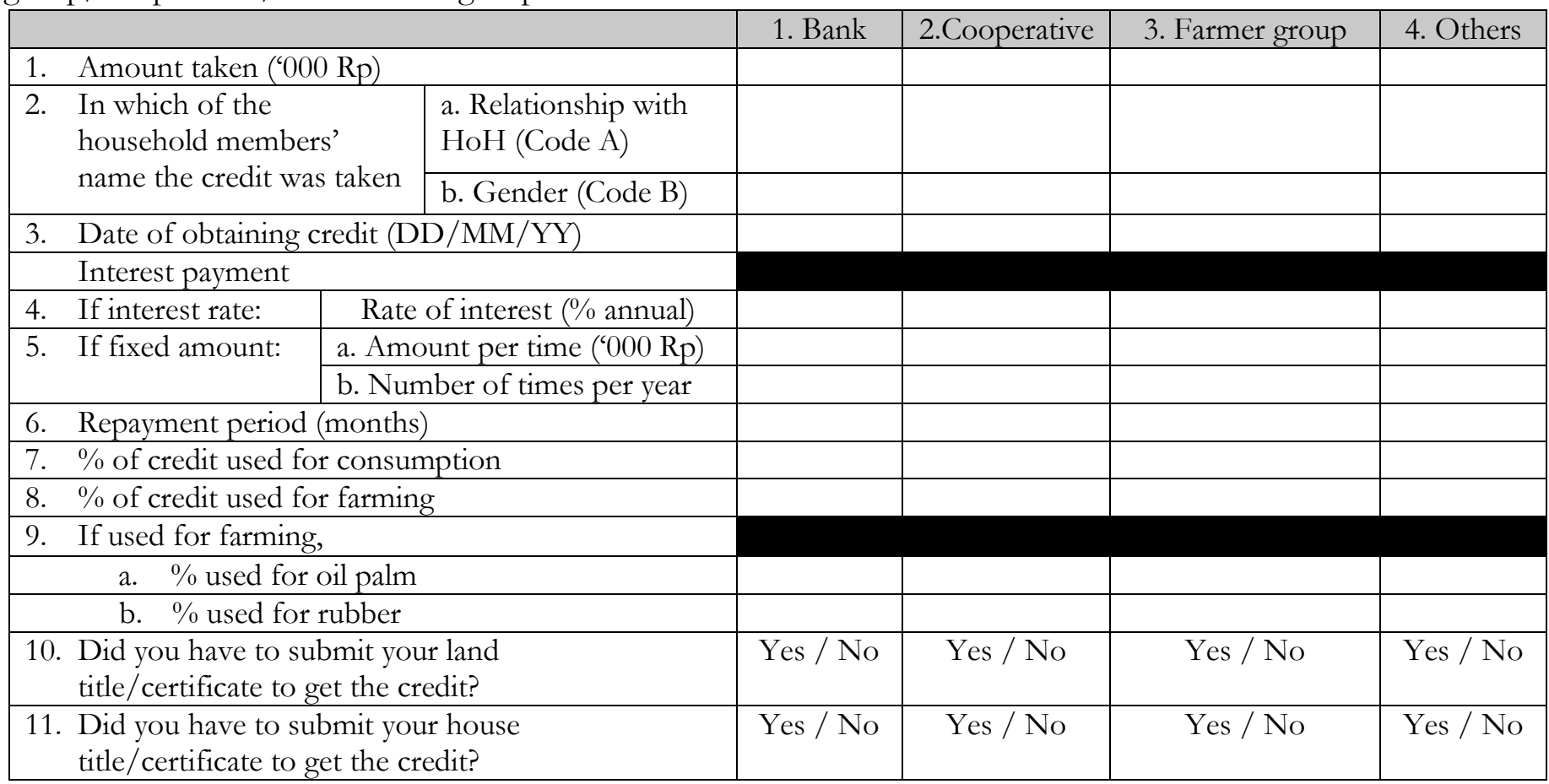

Code A: household head or wife $=1$; son or daughter $=2$; father or mother $=3$; grandchild $=4$; mother or father in law $=5$; son or daughter in law $=6$; brother $/$ sister $=7$; other relative $=8$; non-relative $=9$.

Code $\mathrm{B}$ : male $=1$; female $=2$; both $=3$. 


\subsection{Informal credit sources}

a. Have you taken credit payed back credit during the last 12 months from other households/ trader/ input dealer? .......... (Yes/ No)

b. If yes, type of the institute ......... (Code: Other household $=1$; Trader $=2$; Input dealer $=3$ )

c. If no, what was the main reason for not taking credit? ..........

[Code: Not required or necessary $=1$; Can easily obtain from banks or other formal source $=2$; It is difficult to get $=3$; High interest rate $=4$; No land title to pledge to get credit $=5$; It is morally wrong to take credit $=6$;

Others $=7$ (specify:........................ $]$

d. Who made the decision to borrow? .. (Code B)

e. Who made the decision about what to do with the money borrowed? (Code B)

If credit was taken or being paid back in the last 12 months from trader/ dealer:

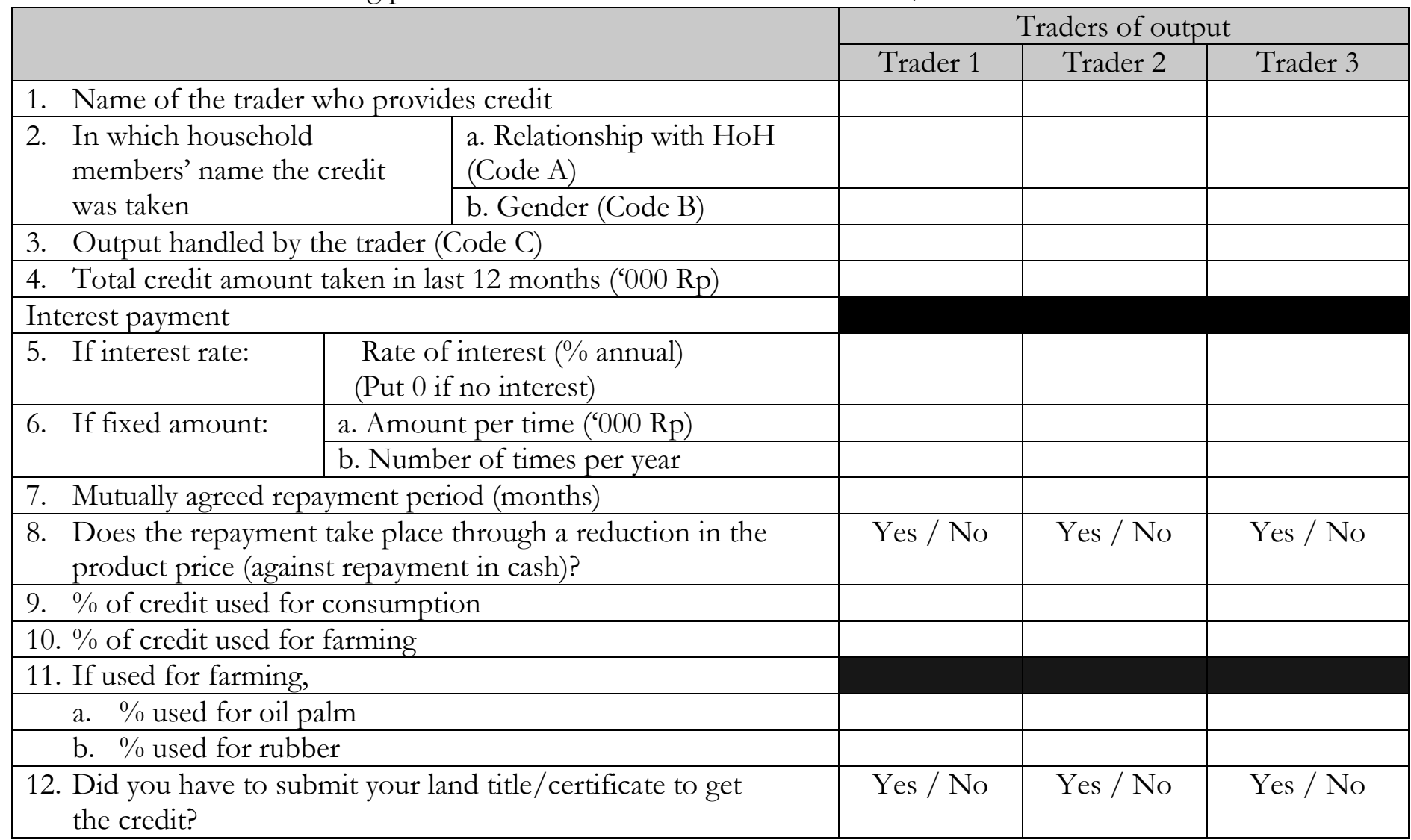

Code A: household head or wife $=1$; son or daughter $=2$; father or mother $=3$; grandchild $=4$; mother or father in law $=5$; son or daughter in law $=6$; brother $/$ sister $=7$; other relative $=8$; non-relative $=9$.

Code B: male $=1$; female $=2$; both $=3$.

Code C: oil palm $=1$; rubber $=2$; rice $=3$; other $($ specify $)=4$ 
If credit was taken or being paid back in the last 12 months from other households/ other informal sources:

\begin{tabular}{|c|c|c|c|c|c|c|}
\hline & \multicolumn{4}{|c|}{ Other household (major credit sources) } \\
\hline & & & HH 1 & HH 2 & HH 3 & $\mathrm{HH} 4$ \\
\hline \multirow{2}{*}{\multicolumn{2}{|c|}{$\begin{array}{l}\text { 1. Which of the household member } \\
\text { took the initiative to obtain credit? }\end{array}$}} & $\begin{array}{l}\text { a. Relationship with } \\
\text { HoH (Code A) }\end{array}$ & & & & \\
\hline & & b. Gender (Code B) & & & & \\
\hline \multirow{2}{*}{\multicolumn{2}{|c|}{$\begin{array}{l}\text { 2. Who made the decision about } \\
\text { what to do with the money } \\
\text { borrowed? }\end{array}$}} & $\begin{array}{l}\text { a. Relationship with } \\
\text { HoH (Code A) }\end{array}$ & & & & \\
\hline & & b. Gender (Code B) & & & & \\
\hline \multicolumn{7}{|c|}{ 3. Total amount taken in last 12 months ('000 Rp) } \\
\hline \multicolumn{7}{|c|}{ Interest payment } \\
\hline 4. If interest rate: & Rate of inte & est (\% annual) & & & & \\
\hline \multirow[t]{2}{*}{ 5. If fixed amount: } & a. Amount pe & time ('000 Rp) & & & & \\
\hline & b. Number of & times per year & & & & \\
\hline \multicolumn{7}{|c|}{$\begin{array}{l}\text { 6. Mutually agreed repayment period (months; NA if not } \\
\text { fixed) }\end{array}$} \\
\hline \multicolumn{7}{|c|}{ 7. His/her farm size (ha; 0 if non-farmer) } \\
\hline \multicolumn{7}{|c|}{$\begin{array}{l}\text { 8. Shortest distance between your farm and his/her farm } \\
(\mathrm{km} \text {; NA if not a farmer })\end{array}$} \\
\hline \multicolumn{3}{|c|}{ 9. Is she/he your relative or friend? } & Yes / No & Yes / No & Yes / No & Yes / No \\
\hline \multicolumn{3}{|c|}{ 10. Does she/he belong to your village? } & Yes / No & Yes / No & Yes / No & Yes / No \\
\hline \multicolumn{3}{|c|}{ 11. Does she/he belong to your dusun? } & Yes / No & Yes / No & Yes / No & Yes / No \\
\hline \multicolumn{7}{|c|}{ 12. What is the distance between your houses? $(\mathrm{km})$} \\
\hline \multicolumn{3}{|c|}{ 13. Do you both belong to same ethnic community? } & Yes/No & Yes /No & Yes / No & Yes / No \\
\hline \multicolumn{3}{|c|}{ 14. Did he/she borrow money from you in past 12 months? } & Yes / No & Yes / No & Yes / No & Yes / No \\
\hline \multicolumn{7}{|c|}{ 15. $\%$ of credit used for consumption } \\
\hline \multicolumn{7}{|c|}{ 16. $\%$ of credit used for farming } \\
\hline \multicolumn{7}{|c|}{ 17. If used for farming, } \\
\hline \multicolumn{7}{|c|}{ a. \% used for oil palm } \\
\hline \multicolumn{3}{|c|}{ b. $\%$ used for rubber } & & & & \\
\hline \multicolumn{3}{|c|}{$\begin{array}{l}\text { 18. Did you have to submit your land title/certificate } \\
\text { to get the credit? }\end{array}$} & Yes / No & Yes / No & Yes / No & Yes / No \\
\hline
\end{tabular}

Code A: household head or wife $=1$; son or daughter=2; father or mother=3; grandchild=4; mother or father in law $=5$; son or daughter in law $=6$; brother $/$ sister $=7$; other relative $=8$; non-relative $=9$.

Code $\mathrm{B}$ : male $=1$; female $=2$; joint $=3$.

\subsection{Savings}

\begin{tabular}{|l|c|c|c|c|}
\hline & 2. Bank & 2.Cooperative & 3. Chit fund & $\begin{array}{c}\text { 4. Other: } \\
(\ldots . . . \ldots . . .)\end{array}$ \\
\hline $\begin{array}{l}\text { 1. Do you have an account or are a member of this } \\
\text { institution? }\end{array}$ & $\begin{array}{c}\text { Yes/No } \\
\text { If no, go } \\
\text { to next } \\
\text { column) }\end{array}$ & $\begin{array}{c}\text { Yes/No } \\
\text { (If no, go to } \\
\text { next column) }\end{array}$ & $\begin{array}{c}\text { Yes/No } \\
\text { (If no, go to } \\
\text { next } \\
\text { column) }\end{array}$ & $\begin{array}{c}\text { Yes/No } \\
\text { (If no, go to } \\
\text { next table) }\end{array}$ \\
\hline 2. Average amount of savings ('000 Rp) & & & \\
\hline
\end{tabular}




\section{Household characteristics}

\subsection{Household member details}

Details of household members.

a. Total members in the household staying in the house:................. (number) during the last 12 months.

b. Religion of HoH: Muslim/ Christian/ Hindu/ Buddhist/ Others (specify: ...)

c. Ethnic group (specify):....

\begin{tabular}{|c|c|c|c|c|c|c|c|c|c|c|c|c|}
\hline \multirow{2}{*}{$\begin{array}{l}\text { 1. HH } \\
\text { member } \\
\text { (Relationship } \\
\text { with HoH) }\end{array}$} & \multirow{2}{*}{ 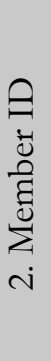 } & \multirow{2}{*}{ 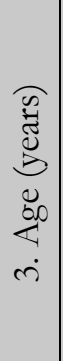 } & \multirow{2}{*}{ 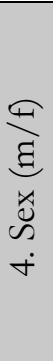 } & \multirow{2}{*}{ 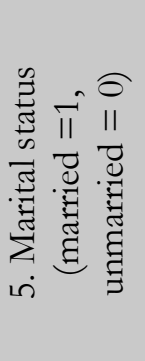 } & \multirow{2}{*}{ 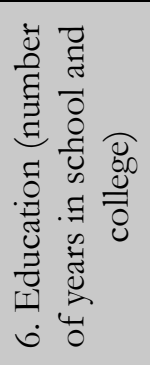 } & \multirow{2}{*}{ 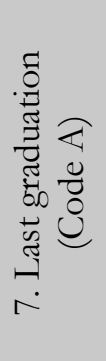 } & \multicolumn{2}{|c|}{$\begin{array}{c}\text { 8. Main } \\
\text { Occupations } \\
\text { (Code B) }\end{array}$} & \multirow{2}{*}{$\begin{array}{c}9 . \\
\text { Did HH } \\
\text { member } \\
\text { work on } \\
\text { households' } \\
\text { farm in last } \\
12 \text { months? } \\
\text { (Yes/No) }\end{array}$} & \multirow{2}{*}{$\begin{array}{c}10 . \\
\text { Searching for } \\
\text { employment? } \\
\text { (Yes/No) }\end{array}$} & \multirow{2}{*}{$\begin{array}{l}11 . \\
\text { What is the } \\
\text { lowest wage in } \\
\text { Rp per day that } \\
\text { the HH member } \\
\text { would accept for } \\
\text { a casual or day } \\
\text { job? }\end{array}$} & \multirow{2}{*}{$\begin{array}{l}12 . \\
\text { What is the } \\
\text { lowest wage in } \\
\text { Rp per day that } \\
\text { the HH member } \\
\text { would accept for } \\
\text { a permanent job? }\end{array}$} \\
\hline & & & & & & & 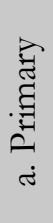 & 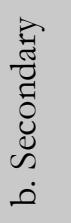 & & & & \\
\hline Respondent & 1 & & & & & & & & & & & \\
\hline \multirow[t]{14}{*}{$\begin{array}{l}\text { Head of } \\
\text { household* }\end{array}$} & 2 & & & & & & & & & & & \\
\hline & 3 & & & & & & & & & & & \\
\hline & 4 & & & & & & & & & & & \\
\hline & 5 & & & & & & & & & & & \\
\hline & 6 & & & & & & & & & & & \\
\hline & 7 & & & & & & & & & & & \\
\hline & 8 & & & & & & & & & & & \\
\hline & 9 & & & & & & & & & & & \\
\hline & 10 & & & & & & & & & & & \\
\hline & 11 & & & & & & & & & & & \\
\hline & 12 & & & & & & & & & & & \\
\hline & 13 & & & & & & & & & & & \\
\hline & 14 & & & & & & & & & & & \\
\hline & 15 & & & & & & & & & & & \\
\hline
\end{tabular}

* Do not fill this column if respondent is head of the household. Use more rows if household size is more than 15.

Code A: never attended=1; attended but not completed=2; completed SD (primary)=3; completed SMP (Middle)=4; completed SMA (High School) =5; D3 or S1 (Associates Degree or University level first stage) $=6$; student at present $=7$; other (specify) $=8$.

Code B: own-agriculture $=1$; wage or contract labor $=2$; own-business activities $=3$; still attending school $=4$; household activities $=5$; other $($ specify $)=6$. 
b. Residency status of household members (Only ask if household is newly added to sample or household head got married after 2015)

\begin{tabular}{|l|c|c|c|}
\hline & \begin{tabular}{c} 
1. Used to live in the \\
village whole life? \\
\cline { 4 - 4 }
\end{tabular} & a. Year of migration to the & b. From where moved to the village (Code B) \\
(Codlage & & & \\
\hline Head of the household $(\mathrm{HoH})$ & & & \\
\hline Parents of the $\mathrm{HoH}$ & & & \\
\hline Spouse of the HoH & & & \\
\hline Parents of the spouse & & & \\
\hline
\end{tabular}

Code A: no $=0$; yes $=1$; never lived in the village $=2$.

Code B: outside village in Jambi $=1$; outside Jambi, but in Sumatra $=2$; outside Sumatra, but in Indonesia $=3$; outside Indonesia $=4$.

c. Activities of $\mathrm{HH}$ members (above the age of 15 and below 65)

Now we like to find out how you spent your time on average working day, [day \& date]. I'll need to know where you were and who else was with you. If an activity is too personal, there's no need to mention it.

So let's begin. On average working day, what were you doing and for how many hours? Please go step by step through the activities of the day. (If the Respondent reports an activity with no associated precode, the interviewer can type the activity directly onto the blank activity line.)

\begin{tabular}{|c|c|c|c|c|c|c|c|c|c|c|c|c|c|c|c|c|c|c|c|c|}
\hline $\begin{array}{l}\text { 1. } \mathrm{HH} \text { member } \\
\text { (Relationship with } \mathrm{HoH} \text { ) }\end{array}$ & $\begin{array}{l}\text { 2. Member } \\
\text { ID }\end{array}$ & $\begin{array}{l}5- \\
6\end{array}$ & $\begin{array}{l}6- \\
7\end{array}$ & $\begin{array}{l}7- \\
8\end{array}$ & $\begin{array}{l}8- \\
9\end{array}$ & $\begin{array}{l}9- \\
10\end{array}$ & $\begin{array}{l}10- \\
11\end{array}$ & $\begin{array}{l}11- \\
12\end{array}$ & $\begin{array}{l}12- \\
13\end{array}$ & $\begin{array}{c}13- \\
14\end{array}$ & $\begin{array}{l}13- \\
15\end{array}$ & $\begin{array}{l}15- \\
16\end{array}$ & $\begin{array}{l}16- \\
17\end{array}$ & $\begin{array}{l}17- \\
18\end{array}$ & $\begin{array}{c}18- \\
19\end{array}$ & $\begin{array}{l}19- \\
20\end{array}$ & $\begin{array}{l}20- \\
21\end{array}$ & $\begin{array}{c}21- \\
22\end{array}$ & $\begin{array}{c}22- \\
23\end{array}$ & $\begin{array}{l}23- \\
24\end{array}$ \\
\hline Respondent & 1 & & & & & & & & & & & & & & & & & & & \\
\hline \multirow[t]{10}{*}{ Head of household* } & 2 & & & & & & & & & & & & & & & & & & & \\
\hline & 3 & & & & & & & & & & & & & & & & & & & \\
\hline & 4 & & & & & & & & & & & & & & & & & & & \\
\hline & 5 & & & & & & & & & & & & & & & & & & & \\
\hline & 6 & & & & & & & & & & & & & & & & & & & \\
\hline & 7 & & & & & & & & & & & & & & & & & & & \\
\hline & 8 & & & & & & & & & & & & & & & & & & & \\
\hline & 9 & & & & & & & & & & & & & & & & & & & \\
\hline & 10 & & & & & & & & & & & & & & & & & & & \\
\hline & 11 & & & & & & & & & & & & & & & & & & & \\
\hline
\end{tabular}

Code A: 1=Sleeping; 2=Working at own farm; 3=Working off-farm; 4=Grooming (self); $5=$ Using TV, Radio, Phone; $6=$ Preparing meals or snack, house-keeping; 7=Eating and drinking; $8=$ Physical activities (sports); 9=Shopping; 10=Attending religious service/other meetings; 11=Other leisure activities; 30=Don't know/ Can't remember; $31=$ Refusal 


\section{2 Asset accumulation}

a. Number of cellphones owned by the household in the present:.........

\begin{tabular}{|c|c|c|c|c|}
\hline & $\begin{array}{l}\text { Number of items } \\
\text { owned. currently }\end{array}$ & $\begin{array}{l}\text { Year of } \\
\text { ownership } \\
\text { /purchase }\end{array}$ & $\begin{array}{l}\text { Purchase } \\
\text { price } \\
\text { ('000 Rp) }\end{array}$ & $\begin{array}{l}\text { Which HHM } \\
\text { owns this } \\
\text { asset? (Code } \\
\text { HHM ID) }\end{array}$ \\
\hline \multicolumn{5}{|l|}{ 1. Television (colour) } \\
\hline & & & & \\
\hline & & & & \\
\hline \multicolumn{5}{|l|}{ 2. Satellite Dish } \\
\hline & & & & \\
\hline & & & & \\
\hline \multicolumn{5}{|l|}{ 3. Motorbike } \\
\hline & & & & \\
\hline & & & & \\
\hline & & & & \\
\hline \multicolumn{5}{|l|}{ 4. Car } \\
\hline & & & & \\
\hline & & & & \\
\hline \multicolumn{5}{|l|}{ 5. 4-wheel tractor } \\
\hline & & & & \\
\hline & & & & \\
\hline \multicolumn{5}{|l|}{ 6. Jeep/Truck } \\
\hline & & & & \\
\hline \multicolumn{5}{|l|}{ 7. Fridge } \\
\hline & & & & \\
\hline & & & & \\
\hline \multicolumn{5}{|l|}{ 8. Air conditioner (AC) } \\
\hline & & & & \\
\hline \multicolumn{5}{|l|}{ 9. Washing machine } \\
\hline & & & & \\
\hline & & & & \\
\hline
\end{tabular}




\subsection{Housing}

[Only ask completely for newly added households; for households already interviewed in 2015 ask only for changes after 2015]

a. Did you build or purchase a house in the last 25 years? .............(Yes/No)

b. If yes, in which year: .............

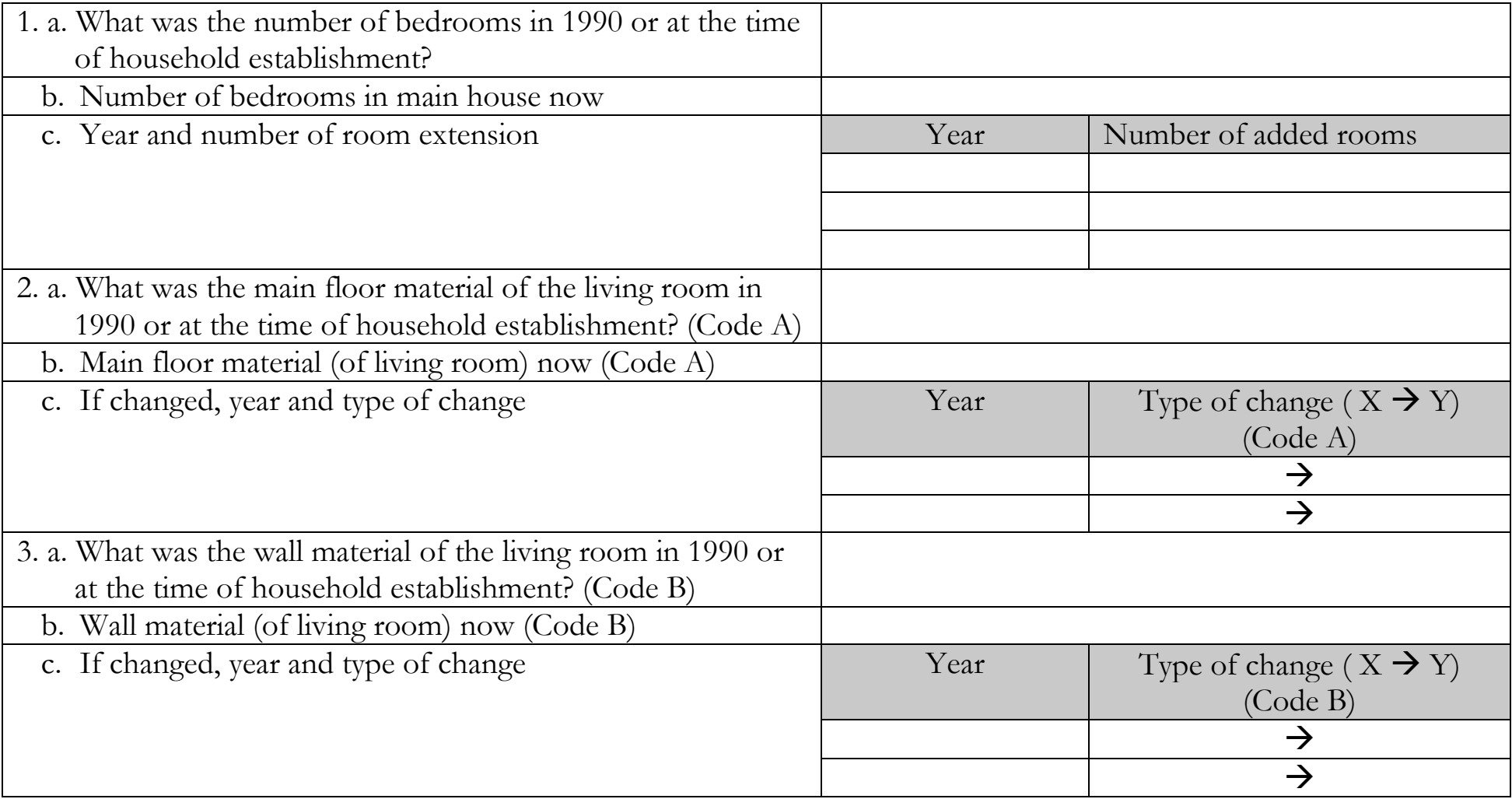

Code A: Tiles=1; Cement=2; Wood=3; Earth=4; Other (specify) $=5$.

Code B: Un-plastered brick=1; Brick covered with cement $=2$; Brick with ceramics $=3$; Low quality wood=4, High quality wood (e.g. ornamentation) $=5$; Other (specify) $=6$ 
13. Non-own agriculture household income sources

13.1. Wage and contract labour

a. Have any of your household members worked as a tenant in a sharecropping arrangement in the last 12 months?

$(\mathrm{Yes} / \mathrm{No})$

If yes: (i). Does the sharecropping landlord belong to your ethnic group? ............ (Yes/No)

(ii). Is the sharecropping landlord your close relative? ............. (Yes/No).

(iii). Did you sign a written agreement before starting the sharecropping? (Yes/No).

(iv). How much does your household (tenant) spend on inputs per month (e.g. fertilizer) for the sharecropped plots? ...........('000 Rp)

b. Have any of your household members worked as daily laborer (daily / weekly / monthly payment of money), as contracted for work (fixed payment for specific jobs) or sharecropping tenants during the last 12 months? ............. (Yes/No). (If no, please go to the next table)

\begin{tabular}{|c|c|c|c|c|c|c|c|c|c|c|c|c|c|}
\hline \multirow[b]{2}{*}{ 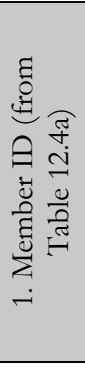 } & \multirow[b]{2}{*}{ 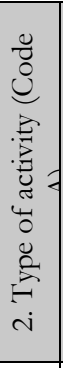 } & \multirow[b]{2}{*}{ 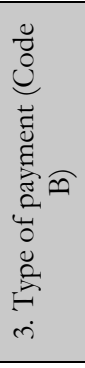 } & \multirow[b]{2}{*}{ 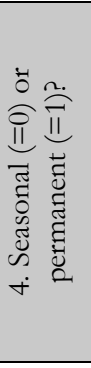 } & \multirow[b]{2}{*}{ 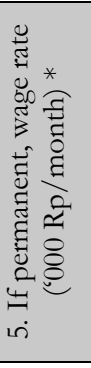 } & \multicolumn{3}{|c|}{ 6. If seasonal } & \multirow[b]{2}{*}{$\begin{array}{c}7 . \\
\text { Receives } \\
\text { wage/profit on } \\
\text { hand (or is the } \\
\text { wage/profit } \\
\text { handed to } \\
\text { another HH } \\
\text { member)? } \\
\text { (Yes/No/NA) }\end{array}$} & \multirow{2}{*}{$\begin{array}{c}8 . \\
\text { Total hours a } \\
\text { member } \\
\text { worked on } \\
\text { average per } \\
\text { month? }\end{array}$} & \multirow{2}{*}{$\begin{array}{c}9 . \\
\text { What is the } \\
\text { duration of the } \\
\text { employment } \\
\text { agreement? } \\
\text { (Months) }\end{array}$} & \multirow{2}{*}{$\begin{array}{c}10 . \\
\text { If agriculture } \\
\text { (Code A), } \\
\text { which crop? } \\
\text { (Code D) }\end{array}$} & \multirow[b]{2}{*}{$\begin{array}{c}11 . \\
\text { When decisions are } \\
\text { made regarding } \\
\text { taking up an } \\
\text { employment, who } \\
\text { is it that normally } \\
\text { takes the decision? } \\
\text { (Code E) }\end{array}$} & \multirow[b]{2}{*}{$\begin{array}{c}12 . \\
\text { Which household } \\
\text { members are more } \\
\text { involved in } \\
\text { deciding the use of } \\
\text { income generated? } \\
\text { (Code E) }\end{array}$} \\
\hline & & & & & 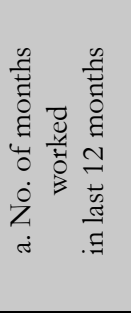 & 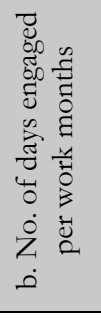 & 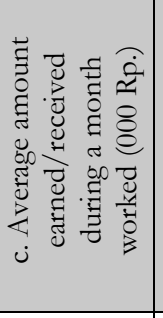 & & & & & & \\
\hline & & & & & & & & & & & & & \\
\hline & & & & & & & & & & & & & \\
\hline & & & & & & & & & & & & & \\
\hline & & & & & & & & & & & & & \\
\hline
\end{tabular}

Code A: work in agriculture $=1$; work in forestry $=2$; work in manufacturing $=3$; work in services $=4$; government employee $=5$; other $($ specify $)=6$

Code B: per hour wage $=1$; daily wage $=2$; weekly wage $=3$; monthly wage $=4$; contract (fixed arrangement) $=6$; other arrangement (specify) $=7$; share cropping arrangement as tenant $=8$.

Code C: $1=$ A week or less; $2=$ More than a week but less than a month; $3=$ One to six months; $4=$ Seven to eleven months; $5=$ One to five years

; $6=$ More than 5 years; $7=$ Don't know

Code D: $1=$ Oil palm; $2=$ Rubber; $3=$ Rice; $4=$ Other

Code E: $1=$ Male; $2=$ Female; $3=$ Both

* Please estimate the monthly income (deducting the input costs) of household members working as sharecropping tenants 


\subsection{Own business activities}

- Did any of your household members gain any income from any type of own-business activities during the last 12 months?.... (If no, please go to the next table)

\begin{tabular}{|c|c|c|c|c|c|c|c|c|c|c|c|}
\hline $\begin{array}{l}\text { 1. Type of } \\
\text { enterprise } \\
\text { or business } \\
\text { (Code A) }\end{array}$ & $\begin{array}{l}\text { 2. Shortly } \\
\text { describe the } \\
\text { type of } \\
\text { business in } \\
\text { words }\end{array}$ & $\begin{array}{c}\text { 3. When } \\
\text { started? } \\
\text { (year) }\end{array}$ & $\begin{array}{l}\text { 4. No. of } \\
\text { family } \\
\text { members } \\
\text { engaged }\end{array}$ & $\begin{array}{l}\text { 5. Household } \\
\text { member who is } \\
\text { mainly } \\
\text { responsible for } \\
\text { the business (ID } \\
\text { from } 12.4 \mathrm{a} \text { ) }\end{array}$ & $\begin{array}{c}5 \mathrm{~b} . \\
\text { Household } \\
\text { members } \\
\text { who help in } \\
\text { business (ID } \\
\text { from } 12.4 \mathrm{a} \text { ) }\end{array}$ & $\begin{array}{l}\text { 5c. } \\
\text { Did the HH } \\
\text { members help } \\
\text { without being } \\
\text { paid directly? } \\
\text { (Yes/No/ } \\
\text { Sometimes) }\end{array}$ & $\begin{array}{l}\text { 6. Total } \\
\text { hours a } \\
\text { member } \\
\text { worked in } \\
\text { business on } \\
\text { average per } \\
\text { month? }\end{array}$ & $\begin{array}{l}\text { 7. Total net } \\
\text { amount } \\
\text { (costs } \\
\text { subtracted) } \\
\text { earned from } \\
\text { business per } \\
\text { month on } \\
\text { average? } \\
\text { ('000 Rp). }\end{array}$ & $\begin{array}{l}\text { 8. Number } \\
\text { of months } \\
\text { the business } \\
\text { was running } \\
\text { during last } \\
12 \text { months? }\end{array}$ & $\begin{array}{c}9 . \\
\text { When } \\
\text { decisions are } \\
\text { made } \\
\text { regarding the } \\
\text { business, who } \\
\text { is it that } \\
\text { normally takes } \\
\text { the decision? } \\
\text { (Code B) }\end{array}$ & $\begin{array}{c}10 . \\
\text { Which } \\
\text { household } \\
\text { members are } \\
\text { more involved } \\
\text { in deciding the } \\
\text { use of income } \\
\text { generated? } \\
\text { (Code B) }\end{array}$ \\
\hline & & & & & & & & & & & \\
\hline & & & & & & & & & & & \\
\hline & & & & & & & & & & & \\
\hline & & & & & & & & & & & \\
\hline
\end{tabular}

Code A: shop=1; trading=2; restaurant (food) $=3$; hotel $($ stay $)=4$; chauffeur $/$ driver $=5$; carpenter $=6$; construction worker $=7$; other $($ specify $)=8$.

Code B: Male $=1 ;$ Female $=2 ;$ Both $=3$

\subsection{Public and private transfers}

- Have any of your household members benefited from some kind of public/NGO transfer program (given money in daily/weekly/monthly basis) during the last 12 months? ................... (Yes/ No). (If no, please go to the next table)

\begin{tabular}{|c|c|c|c|c|c|}
\hline $\begin{array}{c}\text { 1.Member } \\
\text { IDs } \\
\text { (from } \\
12.4 \mathrm{a})\end{array}$ & $\begin{array}{c}\text { 2. Type of } \\
\text { program (Code }\end{array}$ & $\begin{array}{c}\text { 3. Who is providing the } \\
\text { program? (Code B) }\end{array}$ & $\begin{array}{c}\text { 4. What kind of benefits do } \\
\text { you receive? (Code C) }\end{array}$ & $\begin{array}{c}\text { 5. Estimated amount received } \\
\text { during last 12 months ('000 } \\
\text { Rp.) }\end{array}$ & $\begin{array}{c}\text { 6. Which household members } \\
\text { are more involved in deciding } \\
\text { the use of money received? } \\
\text { (Code D) }\end{array}$ \\
\hline & & & & & \\
\hline & & & & & \\
\hline
\end{tabular}

Code A: pensions $=1$; education subsidies $=2$; health care benefits $=3$; poverty reduction program $=4$; others $($ specify $)=5$.

Code B: local government $=1$; federal government $=2 ; \mathrm{NGO}=3$; other (specify) $=4$.

Code $\mathrm{C}$ : cash $=1$; clothes $=2$; food $=3$; agricultural inputs $=4$; others (specify) $=5$.

Code D: Male $=1 ;$ Female $=2 ;$ Both $=3$ 


\subsection{Private transfers and remittances}

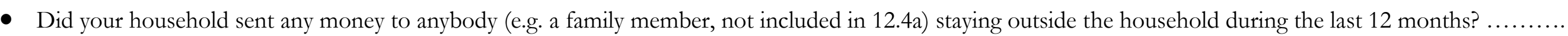
(Yes/No).

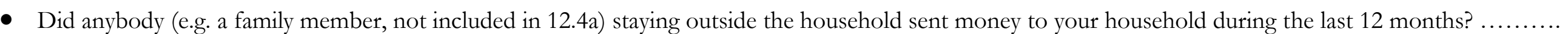
(Yes/No).

(If no to both questions, go to next table.)

\begin{tabular}{|c|c|c|c|c|c|c|c|c|c|}
\hline \multicolumn{4}{|c|}{ 1. If money is sent outside } & \multicolumn{4}{|c|}{ 2. If money is received from outside } & \multirow{2}{*}{\multicolumn{2}{|c|}{$\begin{array}{l}\text { 3. Region where } \\
\text { the sender or } \\
\text { receiver resides } \\
\text { (Code D) }\end{array}$}} \\
\hline \multirow{2}{*}{$\begin{array}{l}\text { a. Receiver's } \\
\text { relation with } \\
\text { your household } \\
\text { head (Code } A \text { ) }\end{array}$} & \multirow{2}{*}{$\begin{array}{c}\text { b. } \\
\text { Receiver's } \\
\text { Gender } \\
(\text { Code B) }\end{array}$} & \multirow{2}{*}{$\begin{array}{c}\text { c. Estimated } \\
\text { amount sent } \\
\text { during last } 12 \\
\text { months ('000 Rp.) }\end{array}$} & \multirow{2}{*}{$\begin{array}{l}\text { d. Main } \\
\text { reasons for } \\
\text { remittance } \\
\text { (Code C) }\end{array}$} & \multirow{2}{*}{$\begin{array}{c}\text { a. Sender's } \\
\text { relation with } \\
\text { your household } \\
\text { head (Code } A)\end{array}$} & \multirow{2}{*}{$\begin{array}{l}\text { b. } \\
\text { Sender's } \\
\text { Gender } \\
\text { (Code B) }\end{array}$} & \multirow{2}{*}{$\begin{array}{c}\text { c. Estimated } \\
\text { amount received } \\
\text { during last } 12 \\
\text { months ('000 Rp.) }\end{array}$} & \multirow{2}{*}{$\begin{array}{l}\text { d. Main } \\
\text { reasons for } \\
\text { remittance } \\
\text { (Code } C \text { ) }\end{array}$} & & \\
\hline & & & & & & & & Receiver & Sender \\
\hline & & & & & & & & & \\
\hline & & & & & & & & & \\
\hline & & & & & & & & & \\
\hline & & & & & & & & & \\
\hline
\end{tabular}

Code A: Son/daughter=1; father or mother=2; grandchild=3; mother or father in law $=4$; son or daughter in law $=5$; other relative $=6$; nonrelative $=7$.

Code B: Male $=1 ;$ Female $=2$.

Code $\mathrm{C}$ : emergency spending $=1$; financing education $=2$; supporting livelihood $=3$, other $($ specify $)=4$.

Code D: outside village in Jambi = 1; outside Jambi, but in Sumatra = 2; outside Sumatra, but in Indonesia = 3; Outside Indonesia = 4; same village =5.

14. Membership in the village-level organizations in last 12 months

\begin{tabular}{|c|c|c|c|c|c|}
\hline $\begin{array}{l}\text { 1. Household member } \\
\text { ID (see Table } 12.4 \mathrm{a} \text { ) }\end{array}$ & $\begin{array}{l}\text { 2. Name of } \\
\text { organization }\end{array}$ & $\begin{array}{l}\text { 3. Position in } \\
\text { organization (other } \\
\text { than being member) }\end{array}$ & $\begin{array}{l}\text { 4. How many } \\
\text { people in the } \\
\text { village participate? }\end{array}$ & $\begin{array}{l}\text { 5. How often do you } \\
\text { meet? (Code A) }\end{array}$ & $\begin{array}{l}\text { 6. Describe functions of the } \\
\text { organisation (Code B) } \\
\text { (Multiple answers allowed) }\end{array}$ \\
\hline & & & & & \\
\hline & & & & & \\
\hline & & & & & \\
\hline
\end{tabular}

Code A: Each year=1; each half year=2; each quarter=3, each month=4; each week=5; no meetings=6; other ( specify) =7.

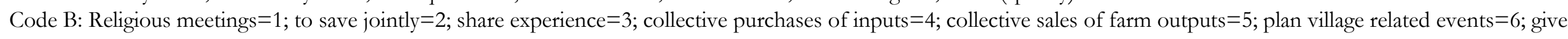
out credit $=7$; other $($ specify $)=8$. 
16. Perceptions of land titles and certification programs

\subsection{Land titles}

a. In the last 15 years, how many conflicts/litigation happened in this village between farmers over land ownership? ...... number

b. Are there any incidents in the village over the last 15 years that the land was taken from a farmer by government agencies or plantation/mining companies using force? ............. (yes $=1 ;$ no $=0 ; \mathrm{NI}=$ No idea)

Details on land title documents:

\begin{tabular}{|ll|l|l|}
\hline & No title & With sporadic & With systematic \\
\hline $\begin{array}{l}\text { 1. } \\
\text { What is the maximum amount of credit obtainable from a bank, having one }\end{array}$ & & \\
\hline $\begin{array}{l}\text { 2. } \\
\text { Pruchase price of one hectare of land without plantation but with road access } \\
\left({ }^{\prime}(000) \mathrm{Rp}\right.\end{array}$ & & \\
\hline
\end{tabular}

Details on land rights:

\begin{tabular}{|c|c|c|c|c|c|c|}
\hline $\begin{array}{l}\text { Report answers } \\
\text { only if households } \\
\text { is involved in the } \\
\text { respective tenure } \\
\text { arrangement }\end{array}$ & $\begin{array}{l}\text { 1. Does the tenure } \\
\text { arrangement allow } \\
\text { renting out the land to } \\
\text { others (without } \\
\text { approval outside of the } \\
\text { household)? }\end{array}$ & $\begin{array}{l}\text { 2. Does the tenure } \\
\text { arrangement allow } \\
\text { selling the land to others } \\
\text { (without approval } \\
\text { outside of the } \\
\text { household)? }\end{array}$ & $\begin{array}{l}\text { 3. Does the tenure } \\
\text { arrangement allow to } \\
\text { pass on the land? }\end{array}$ & $\begin{array}{l}\text { 4. Does the tenure } \\
\text { arrangement protect you } \\
\text { from claims of } \\
\text { neighbors? }\end{array}$ & $\begin{array}{l}\text { 5. Does the tenure } \\
\text { arrangement protect you } \\
\text { from claims of the } \\
\text { district government? }\end{array}$ & $\begin{array}{l}\text { 6. Does the tenure } \\
\text { arrangement protect you } \\
\text { from claims of the } \\
\text { national government? }\end{array}$ \\
\hline 1. No land title & Yes/No & $\mathrm{Yes} / \mathrm{No}$ & Yes/No & Yes/No & $\mathrm{Yes} / \mathrm{No}$ & Yes/No \\
\hline 2. Sporadic & Yes/No & Yes/No & Yes/No & Yes/No & $\mathrm{Yes} / \mathrm{No}$ & Yes/No \\
\hline 3. Systematic & Yes/No & $\mathrm{Yes} / \mathrm{No}$ & Yes/No & $\mathrm{Yes} / \mathrm{No}$ & $\mathrm{Yes} / \mathrm{No}$ & Yes/No \\
\hline 4. Other:......... & Yes/No & Yes/No & Yes/No & $\mathrm{Yes} / \mathrm{No}$ & $\mathrm{Yes} / \mathrm{No}$ & Yes/No \\
\hline
\end{tabular}


16.2 Certification schemes

\begin{tabular}{|c|c|c|}
\hline & $\begin{array}{c}\text { ISPO } \\
\text { Indonesian Sustainable Palm Oil } \\
\text { Certification }\end{array}$ & $\begin{array}{c}\text { RSPO } \\
\text { Roundtable on Sustainable } \\
\text { Palm Oil Certification }\end{array}$ \\
\hline $\begin{array}{l}\text { 1. Are you familiar with the name of the certification schemes? } \\
(1=\text { yes; } 0=\text { no) (If no, go to next column/section) }\end{array}$ & & \\
\hline 2. How have you heard about the schemes? (Code A) & & \\
\hline $\begin{array}{l}\text { 3. Are you currently involved in any of these certification schemes? } \\
(1=\text { yes; } 0=\text { no) (If no, go to next column/section) }\end{array}$ & & \\
\hline 4. If yes, since which year are you involved? & & \\
\hline
\end{tabular}

Code A: Other farmers $=1$; Processing companies $=2$; Government agencies $=3$; Non-Governmental organizations $=4$; Mass media $=5$; Others $($ specify) $=6$,

Code B: Requirement by processing company $=1$; legal requirement $=2$; expecting higher prices $=3$; expecting higher output $=4$; got external support for implementing scheme $=$

5 ; health benefits $=6$; others (specify) $=7$ 


\section{Household Survey Questionnaire C07 \\ (Consumption; Round 3, 2018)}

1. Household identification

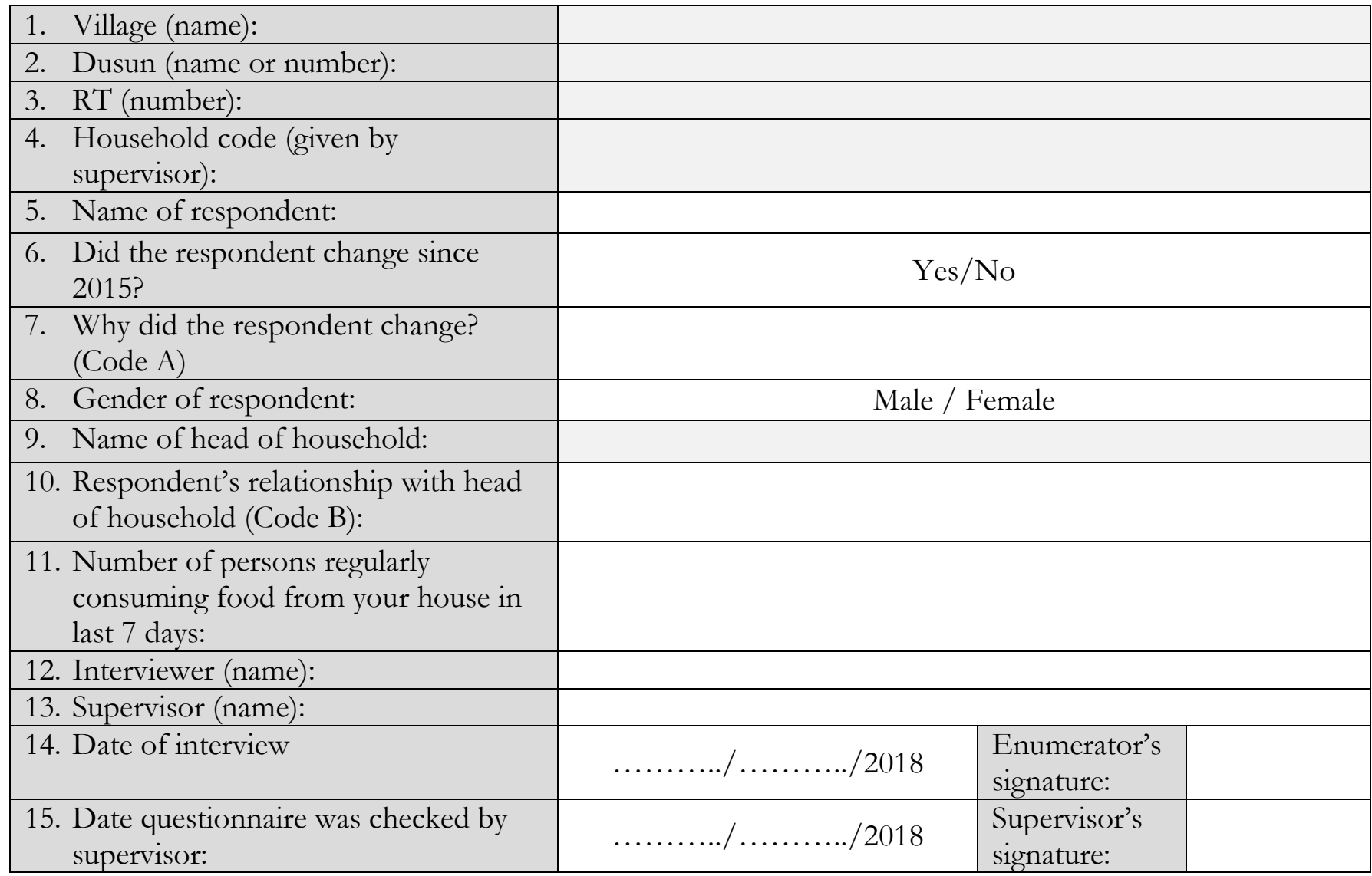

Code A: currently out of village $=1$, moved out of the household $=2$; passed away $=3$; other (specify) $=4$

Code B: Wife/Husband $=1$; Daughter $/$ Son $=2 ;$ Mother $/$ Father $=3$; Sister $/$ Brother $=4$;

Niece $/$ Nephew $=5 ;$ Others (specify) $=6$

2. Household expenditure: In the following questions, we want to ask about all items consumed in your household, regardless of which person consumed it.

2.1.1. Weekly consumption: Has your household consumed following goods during the past 7 days? Please exclude from your answer any purchases for processing or resale in a household enterprise.

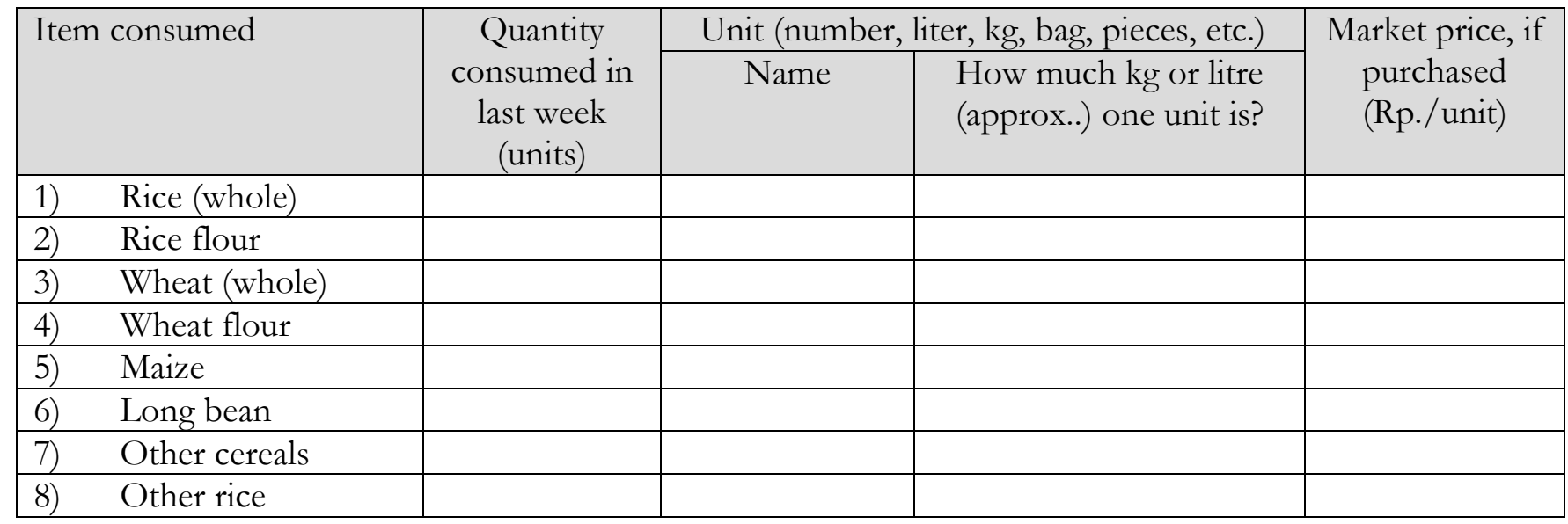




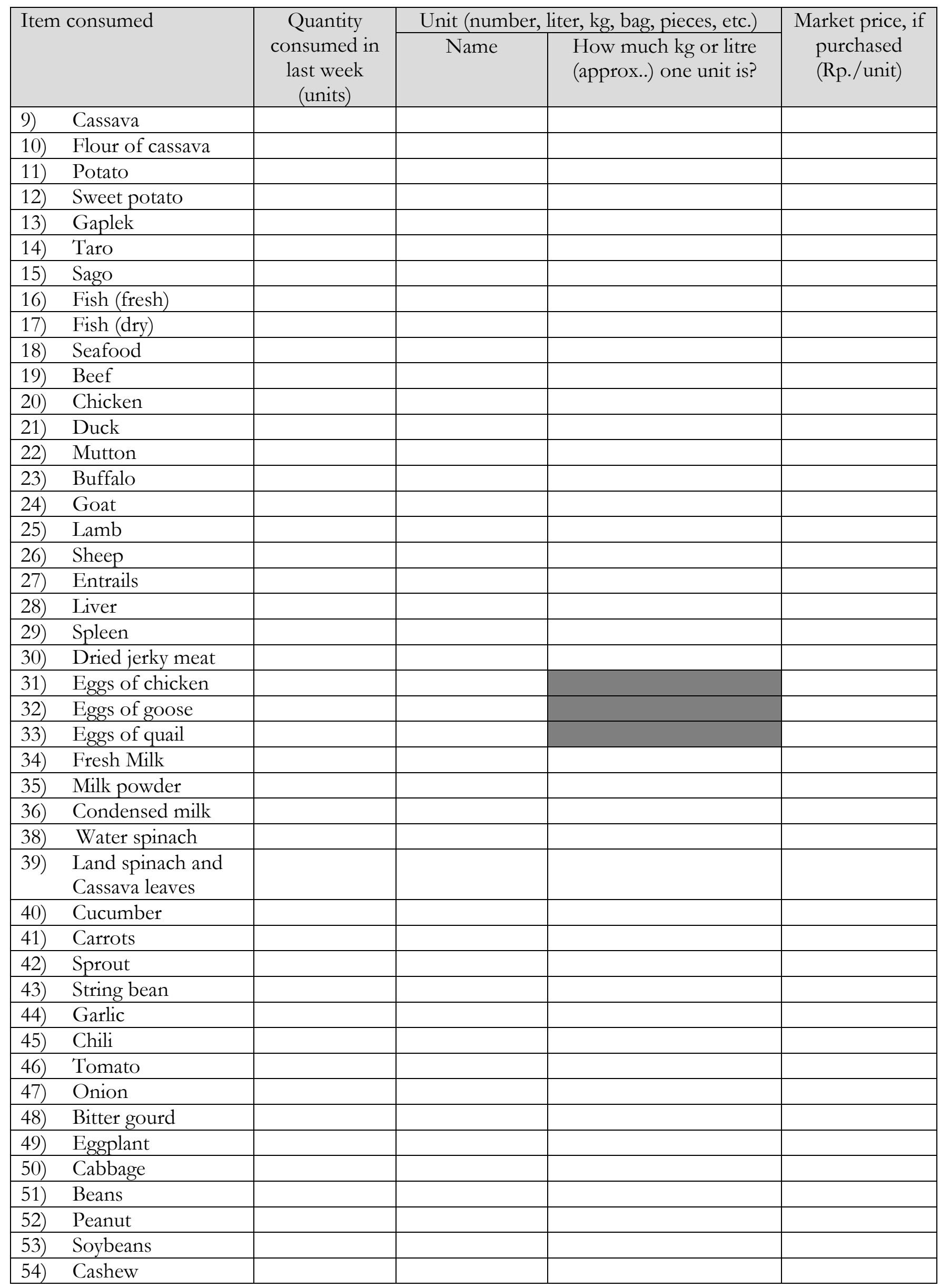




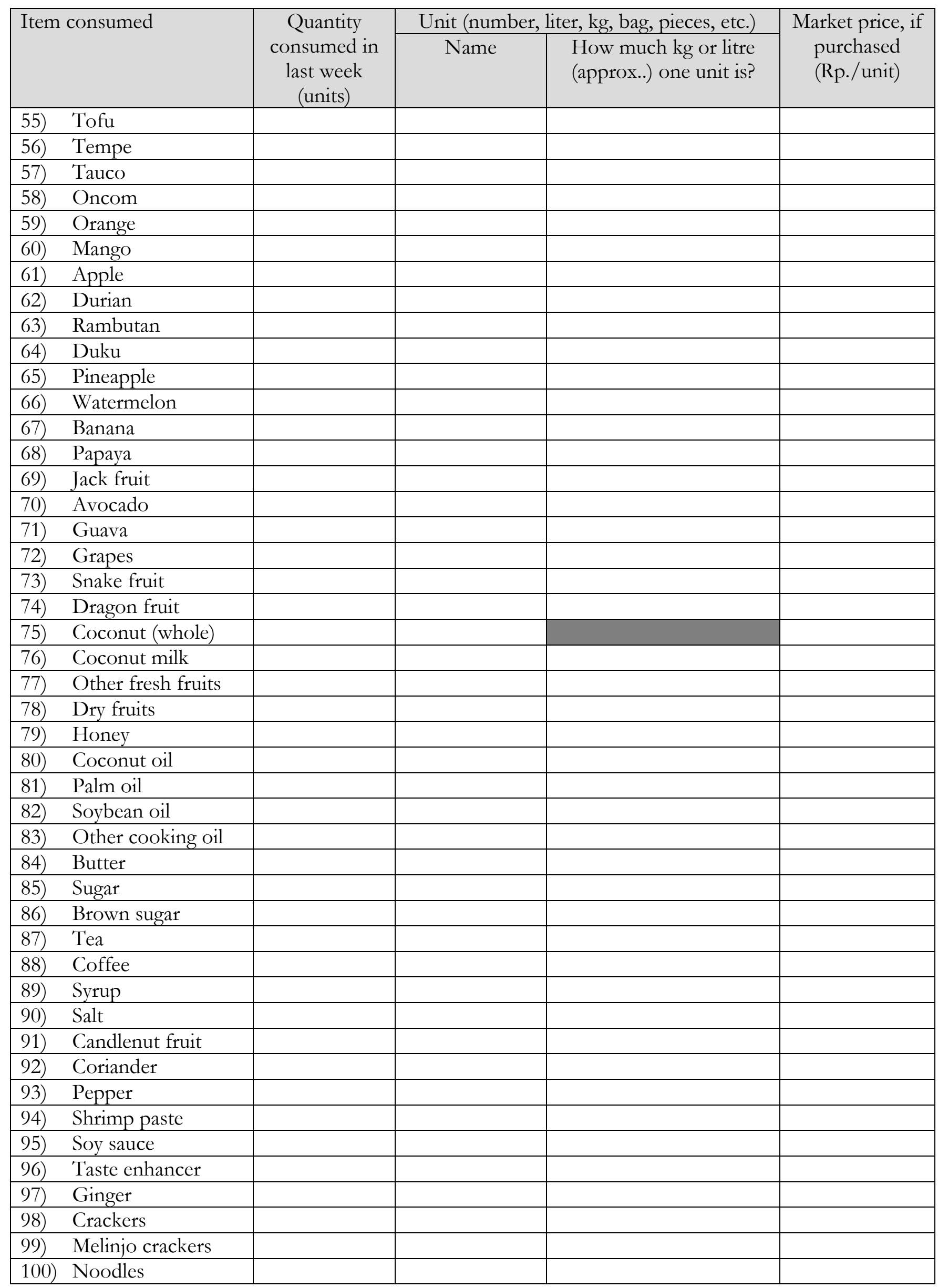




\begin{tabular}{|c|c|c|c|c|}
\hline \multirow[t]{2}{*}{ Item consumed } & \multirow{2}{*}{$\begin{array}{l}\text { Quantity } \\
\text { consumed in } \\
\text { last week } \\
\text { (units) }\end{array}$} & \multicolumn{2}{|c|}{ Unit (number, liter, kg, bag, pieces, etc.) } & \multirow{2}{*}{$\begin{array}{l}\text { Market price, if } \\
\text { purchased } \\
\text { (Rp./unit) }\end{array}$} \\
\hline & & Name & $\begin{array}{l}\text { How much kg or litre } \\
\text { (approx..) one unit is? }\end{array}$ & \\
\hline 101) Rice noodles & & & & \\
\hline 102) Macaroni noodles & & & & \\
\hline 103) Bread & & & & \\
\hline 104) Biscuits & & & & \\
\hline 105) Cakes & & & & \\
\hline 106) Porridge & & & & \\
\hline 107) Meatballs & & & & \\
\hline 108) Iced syrup & & & & \\
\hline $\begin{array}{l}\text { 109) Assorted vegetable } \\
\text { with peanut sauce }\end{array}$ & & & & \\
\hline 110) Snacks & & & & \\
\hline 111) Readymade soups & & & & \\
\hline 112) Canned food & & & & \\
\hline 113) Mie instan & & & & \\
\hline $\begin{array}{l}\text { 114) Nasi goreng Nasi } \\
\text { kuning }\end{array}$ & & & & \\
\hline 115) Nasi Bungkus & & & & \\
\hline 116) Fried bananas & & & & \\
\hline 117) Baby food & & & & \\
\hline 118) Bottled water & & & & \\
\hline 119) Cola, soda etc. & & & & \\
\hline 120) Fresh fruit juices & & & & \\
\hline 121) Lemonade & & & & \\
\hline 122) Clove cigarettes & & & & \\
\hline 123) Tobacco cigarettes & & & & \\
\hline 124) Cigars & & & & \\
\hline 125) Tobacco & & & & \\
\hline 126) Betel leaves & & & & \\
\hline $\begin{array}{l}\text { 127) Betel nut and } \\
\text { others }\end{array}$ & & & & \\
\hline
\end{tabular}

\begin{tabular}{|c|c|c|c|}
\hline Outside house food consumption & $\begin{array}{c}\text { No. of times in } \\
\text { last week }\end{array}$ & No. people/time & $\begin{array}{c}\text { Cost ('000 } \\
\text { Rp/person/time) }\end{array}$ \\
\hline 128) Breakfast & & & \\
\hline 129) Lunch & & & \\
\hline 130) Dinner & & & \\
\hline 131) Tea/Coffee/Snacks & & & \\
\hline
\end{tabular}




\subsubsection{Consumption in last $24 \mathrm{~h}$ of women:}

Which food and drinks and how much of it did you (alone not your household) consumed yesterday? Please indicate which food items, procession and where did you get it from? Writ down all the foods and drinks mentioned. When composite dishes are mentioned, ask for the list of ingredients. When the respondents has finished, prob for the meals and snacks not mentioned. Please exclude from your answer any purchases for processing or resale in a household enterprise.

\begin{tabular}{|c|c|c|c|c|}
\hline \multicolumn{5}{|c|}{ Which day of the week does this record represent? (Code A) } \\
\hline \multicolumn{5}{|c|}{ Is this a typical day? Yes, please specify $=1, \mathrm{No}=0$} \\
\hline 3 & 4 & \multicolumn{2}{|c|}{5} & 6 \\
\hline $\begin{array}{l}\text { Item consumed (Code: use } \\
\text { item code from question } \\
\text { 2.1.1) }\end{array}$ & Quantity & $\begin{array}{l}\text { Unit (number, } \\
\text { liter, kg, bag, } \\
\text { pieces, etc.) }\end{array}$ & $\begin{array}{l}\text { Source of food } \\
\text { (Code B) }\end{array}$ & $\begin{array}{l}\text { Food preparation } \\
\text { (Code C) }\end{array}$ \\
\hline \multicolumn{5}{|l|}{ Breakfast } \\
\hline \multicolumn{5}{|l|}{ Snacks } \\
\hline \multicolumn{5}{|l|}{ Lunch } \\
\hline \multicolumn{5}{|l|}{ Snack } \\
\hline \multirow{2}{*}{\multicolumn{5}{|c|}{ Dinner }} \\
\hline & & & & \\
\hline Snack & & & & \\
\hline & & & & \\
\hline
\end{tabular}

Code A: 1 Monday; 2 Tuesday; 3 Wednesday; 5 Friday; 6 Suturday; 7 Sunday

Code B: $\quad 1$ Own production; 2 Purchased; 3 Gift; 77 Others, specifiy

Code C: 1 Raw; 2 Dried; 3 Boiled; 4 Steamed; 5 Cooked; 6 Fried; 7 Processed; 8 Roasted; 77 Others, specify

\begin{tabular}{|l|l|l|}
\hline $\begin{array}{l}\text { Outside house food consumption } \\
\text { Item consumed (Code: use item code from question } \\
2.1 .1\end{array}$ & Quantity & $\begin{array}{l}\text { Unit (number, } \\
\text { liter, kg, bag, } \\
\text { pieces, etc.) }\end{array}$ \\
\hline Breakfast & & \\
\hline & & \\
\hline Lunch & & \\
\hline Dinner & & \\
\hline & & \\
\hline Tea/Coffee/Snacks & & \\
\hline & & \\
\hline
\end{tabular}


2.1.3. Consumption in the last $24 \mathrm{~h}$ of children below or equal to $5 \mathrm{y}$ :

Which food and drinks and how much of it did your child (the child alone, not your household) consumed yesterday? Please indicate which food items, procession and where did you get it from? Writ down all the foods and drinks mentioned. When composite dishes are mentioned, ask for the list of ingredients. When the respondents have finished, prob for the meal and snacks not mentioned. Please exclude from your answer any purchases for processing or resale in a household enterprise. In case, a family has more than one child below or equal to 5 years, please take the eldest one.

\begin{tabular}{|c|c|c|c|c|}
\hline \multicolumn{5}{|c|}{ Which day of the week does this record represent? (Code A) } \\
\hline \multicolumn{5}{|c|}{ Is this a typical day? Yes, please specify $=1, \mathrm{No}=0$} \\
\hline 3 & 4 & \multicolumn{2}{|c|}{5} & 6 \\
\hline $\begin{array}{l}\text { Item consumed (Code: use } \\
\text { item code from question } \\
2.1 .1 \text { ) }\end{array}$ & Quantity & $\begin{array}{l}\text { Unit (number, } \\
\text { liter, } \mathrm{kg}, \mathrm{bag}, \\
\text { pieces, etc.) } \\
\end{array}$ & $\begin{array}{l}\text { Source of food } \\
\text { (Code B) }\end{array}$ & $\begin{array}{c}\text { Food preparation } \\
\text { (Code C) }\end{array}$ \\
\hline \multicolumn{5}{|l|}{ Breakfast } \\
\hline \multicolumn{5}{|l|}{ Snacks } \\
\hline \multirow{2}{*}{\multicolumn{5}{|c|}{ Lunch }} \\
\hline & & & & \\
\hline \multicolumn{5}{|l|}{ Snack } \\
\hline & & & & \\
\hline \multicolumn{5}{|l|}{ Dinner } \\
\hline & & & & \\
\hline \multicolumn{5}{|l|}{ Snack } \\
\hline & & & & \\
\hline
\end{tabular}

Code A: 1 Monday; 2 Tuesday; 3 Wednesday; 5 Friday; 6 Suturday; 7 Sunday

Code B: 1 Own production; 2 Purchased; 3 Gift; 77 Others, specifiy

Code C: 1 Raw; 2 Dried; 3 Boiled; 4 Steamed; 5 Cooked; 6 Fried; 7 Processed; 8 Roasted; 77 Others, specify

\begin{tabular}{|l|l|l|}
\hline $\begin{array}{l}\text { Outside house food consumption } \\
\text { Item consumed (Code: use item code from question } \\
2.1 .1 \text { ) }\end{array}$ & Quantity & $\begin{array}{l}\text { Unit (number, liter, } \\
\mathrm{kg}, \mathrm{bag}, \text { pieces, etc.) }\end{array}$ \\
\hline Breakfast & & \\
\hline Lunch & & \\
\hline & & \\
\hline Dinner & & \\
\hline & & \\
\hline Tea/Coffee/Snacks & & \\
\hline
\end{tabular}


2.2. Monthly and annual consumption: Has your household bought or received gifts during the past 30 days / 12 months? Please exclude from your answer any purchases for processing or resale in a household enterprise.

\begin{tabular}{|c|c|c|c|}
\hline \multicolumn{2}{|l|}{ Item } & $\begin{array}{c}\text { Monthly expenditure ('000 } \\
\text { Rp./month) }\end{array}$ & $\begin{array}{l}\text { Yearly expenditure ('000 } \\
\text { Rp. / year) }\end{array}$ \\
\hline 137) & Rent of house if contracted & & \\
\hline 138) & Rent, estimated if house is owned & & \\
\hline 139) & Electricity bill (not for generator) & & \\
\hline 140) & Telephone bill (fixed phone line) & & \\
\hline 141) & Gas bill (kitchen) & & \\
\hline 142) & Kerosene bill & & \\
\hline 143) & Water bill & & \\
\hline 144) & Firewood & & \\
\hline 145) & House maintenance and renovation & & \\
\hline 146) & $\begin{array}{l}\text { Personal care items (soap, shampoo, } \\
\text { toothpaste, etc.) }\end{array}$ & & \\
\hline 147) & $\begin{array}{l}\text { Personal services (haircuts, shaving, } \\
\text { etc.) }\end{array}$ & & \\
\hline 148) & Cosmetics & & \\
\hline 149) & Tailoring expenses & & \\
\hline 150) & Laundry & & \\
\hline 151) & Newspaper and magazines & & \\
\hline 152) & Membership fees & & \\
\hline 153) & Toys & & \\
\hline 154) & Making of ID card/ drivers license & & \\
\hline 155) & Telephone card (mobile phone) & & \\
\hline 156) & Postal goods & & \\
\hline 157) & Recreation & & \\
\hline 158) & Entertainment (e.g., movies, drama) & & \\
\hline 159) & Travel & & \\
\hline 160) & Ornaments & & \\
\hline 161) & Registration fee & & \\
\hline 162) & SPP & & \\
\hline 163) & $\begin{array}{l}\text { POMG/BP3 / entrance- / re- } \\
\text { registration fee }\end{array}$ & & \\
\hline 164) & Boy scout & & \\
\hline 165) & Handcraft & & \\
\hline 166) & Courses & & \\
\hline 167) & Hospital & & \\
\hline 168) & Community health center & & \\
\hline 169) & Doctor's practice & & \\
\hline 170) & Traditional healer & & \\
\hline 171) & Medicine & & \\
\hline 172) & Footwear (men, women and children) & & \\
\hline 173) & Clothing (men, women and children) & & \\
\hline 174) & Household tools & & \\
\hline 175) & Hand tools & & \\
\hline 176) & Kitchen tools & & \\
\hline 177) & Television & & \\
\hline
\end{tabular}




\begin{tabular}{|c|c|c|c|}
\hline Item & & $\begin{array}{c}\text { Monthly expenditure ('000 } \\
\text { Rp./month) }\end{array}$ & $\begin{array}{l}\text { Yearly expenditure ('000 } \\
\text { Rp. /year) }\end{array}$ \\
\hline 178) & Dish TV & & \\
\hline 179) & Other entertainment facilities & & \\
\hline 180) & Sports equipment & & \\
\hline 181) & Jewelry & & \\
\hline 182) & Vehicles & & \\
\hline 183) & Umbrellas & & \\
\hline 184) & Wristwatch & & \\
\hline 185) & Camera & & \\
\hline 186) & Install telephone & & \\
\hline 187) & Install electricity & & \\
\hline 188) & Electronic equipment & & \\
\hline 189) & $\begin{array}{l}\text { Taxes (House and building tax, TV } \\
\text { fee, motor vehicle tax) }\end{array}$ & & \\
\hline 190) & Insurance (accident, health insurance) & & \\
\hline 191) & Celebration 1 (name: & & \\
\hline 192) & Celebration 2 (name: & & \\
\hline 193) & Celebration 3 (name: & & \\
\hline
\end{tabular}

2.3 Consumption of energy (fuel, light \& household appliances) during the last 30 days

\begin{tabular}{|c|c|c|c|c|}
\hline Item & & Unit (name) & $\begin{array}{l}\text { Quantity consumed in } \\
\text { last one month (units) }\end{array}$ & $\begin{array}{l}\text { Market price ('000 Rp. } \\
\text { / unit) if purchased }\end{array}$ \\
\hline 194) & Dung cake & & & \\
\hline 195) & Coal, Charcoal, Briquettes, coke & & & \\
\hline 196) & LPG [excl. conveyance] & & & \\
\hline & a. $3 \mathrm{~kg}$ (subsidized) & & & \\
\hline & b. $15 \mathrm{~kg}$ (non subsidized) & & & \\
\hline 197) & Battery & & & \\
\hline 198) & Accu/ aki (car battery) & & & \\
\hline 199) & Generator & & & \\
\hline & a. Petrol (only for generator) & & & \\
\hline & b. Diesel (only for generator) & & & \\
\hline & $\begin{array}{l}\text { c. Lubricants oil (only for } \\
\text { generator) }\end{array}$ & & & \\
\hline & $\begin{array}{l}\text { d. Oil for generator } \\
\text { maintenance (minyak rem, } \\
\text { kanvas, etc) }\end{array}$ & & & \\
\hline 200$)$ & Other fuel & & & \\
\hline 201$)$ & $\begin{array}{l}\text { Other consumption (Matches, } \\
\text { Candle, air freshener, Mosquito } \\
\text { repellent etc) }\end{array}$ & & & \\
\hline
\end{tabular}


2.4 Public transport expenditures during the last 30 days

\begin{tabular}{|c|c|c|}
\hline \multicolumn{2}{|l|}{ Item } & Total expenditure in last month ('000 Rp) \\
\hline 202) & Public bus/tram fare & \\
\hline 203$)$ & Public minibus (angkot) fare & \\
\hline 204$)$ & Air fare & \\
\hline 205$)$ & Public motorcycle (ojek) & \\
\hline 206$)$ & Taxi, auto-rickshaw fare & \\
\hline 207$)$ & Rental car & \\
\hline 208) & $\begin{array}{l}\text { Other public conveyance expense (such as } \\
\text { porter charges, horse cart fare, etc) }\end{array}$ & \\
\hline
\end{tabular}

2.5 Private transport expenditures during the last 30 days

\begin{tabular}{|c|c|c|c|}
\hline Item & & $\begin{array}{l}\text { Fuel cost in last } \\
\text { month ('000 Rp) }\end{array}$ & $\begin{array}{l}\text { Other expenditures in last month } \\
\text { (lubricants, other fuel for vehicle, oil } \\
\text { for maintenance, etc) ('000 Rp) }\end{array}$ \\
\hline 209) & Private car & & \\
\hline 210$)$ & Private minibus & & \\
\hline 211) & Private bus & & \\
\hline 212) & Private motorcycle & & \\
\hline 213) & $\begin{array}{l}\text { Other private transport (please } \\
\text { mention) }\end{array}$ & & \\
\hline
\end{tabular}

2.6 Hadj

Religion of the household members:

Islam/Others (If others, go to 3)

If Islam, have any of the household members gone to Hadj? Yes/No

If yes, details of past pilgrimages:

\begin{tabular}{|c|c|c|}
\hline Year of Hadj & $\begin{array}{c}\text { Number of household } \\
\text { members went }\end{array}$ & $\begin{array}{c}\text { If gone for Hadj after 2015, expenditure } \\
\text { incurred (million Rp) }\end{array}$ \\
\hline & & \\
\hline & & \\
\hline & & \\
\hline
\end{tabular}

Are you planning to go for Hadj in the near future? Yes/No

If yes, are you saving for Hadj, currently? Yes/No

If yes, average savings, kept for this purpose: ........... thousand Rp/year. 


\subsection{Food insecurity}

Now I would like to ask you some questions about the state of your food consumption

\begin{tabular}{|l|l|l|l|}
\hline Was there a time, when... & $\begin{array}{c}\text { 1. In the last } \\
\text { week }\end{array}$ & $\begin{array}{c}\text { 2. If the answer is } \\
\text { NOT "YES" for } \\
\text { the week, in the last } \\
\text { month }\end{array}$ & $\begin{array}{c}\text { 3. If the answer is } \\
\text { NOT "YES" for the } \\
\text { week, in the last 12 } \\
\text { months }\end{array}$ \\
\hline $\begin{array}{l}\text { 1. You were worried you would run } \\
\text { out of food because of a lack of } \\
\text { money or other resources? }\end{array}$ & & \\
\hline $\begin{array}{l}\text { 2. You were unable to eat healthy } \\
\text { and nutritious food because of a } \\
\text { lack of money or other resources? }\end{array}$ & & \\
\hline $\begin{array}{l}\text { 3. You ate only a few kinds of foods } \\
\text { because of a lack of money or } \\
\text { other resources? }\end{array}$ & & \\
\hline $\begin{array}{l}\text { 4. You had to skip a meal because } \\
\text { there was not enough money or } \\
\text { other resources to get food? }\end{array}$ & & \\
\hline $\begin{array}{l}\text { 5. You ate less than you thought you } \\
\text { should because of a lack of money } \\
\text { or other resources? }\end{array}$ & & \\
\hline $\begin{array}{l}\text { 6. Your household ran out of food } \\
\text { because of a lack of money or } \\
\text { other resources? }\end{array}$ & & \\
\hline $\begin{array}{l}\text { 7. You were hungry but did not eat } \\
\text { because there was not enough } \\
\text { money or other resources for } \\
\text { food? }\end{array}$ & & & \\
\hline $\begin{array}{l}\text { 8. You went without eating for a } \\
\text { whole day because of a lack of } \\
\text { money or other resources? }\end{array}$ & & & \\
\hline $\begin{array}{l}\text { 9or how many days you went } \\
\text { without eating for a whole day? }\end{array}$ & & & \\
\hline
\end{tabular}

Code: $0=$ No, 1:=Yes, 98:=Don't know/remember, 99= Refused to answer 


\section{Decision-making and time allocation}

3.1. Who is primarily responsible for the following consumption expenditure items and tasks?

\begin{tabular}{|c|c|c|c|c|}
\hline \multirow[t]{2}{*}{$\begin{array}{l}\text { Consumption and task } \\
\text { items }\end{array}$} & \multirow[t]{2}{*}{ Examples } & \multicolumn{3}{|c|}{$\begin{array}{l}\text { Persons involved (Put } \sqrt{\text { mark or NA if not }} \\
\text { applicable) }\end{array}$} \\
\hline & & $\begin{array}{c}\text { Male } \\
\text { members }\end{array}$ & $\begin{array}{l}\text { Female } \\
\text { members }\end{array}$ & $\begin{array}{c}\text { Both male and } \\
\text { female members } \\
\text { equally }\end{array}$ \\
\hline Purchase of food items & $\begin{array}{l}\text { Rice, vegetables, meat } \\
\text { etc. }\end{array}$ & & & \\
\hline Paying the bills & $\begin{array}{l}\text { Telephone, electricity, } \\
\text { gas etc. }\end{array}$ & & & \\
\hline $\begin{array}{l}\text { Selecting clothing and } \\
\text { footwear }\end{array}$ & $\begin{array}{l}\text { Clothes, tailoring, } \\
\text { footwear etc. }\end{array}$ & & & \\
\hline $\begin{array}{l}\text { Paying for recreation and } \\
\text { membership }\end{array}$ & Movies etc. & & & \\
\hline $\begin{array}{l}\text { Spending on education of } \\
\text { children (if applicable) }\end{array}$ & School fees, books etc. & & & \\
\hline Travel and transport & Taxi, public bus etc. & & & \\
\hline $\begin{array}{l}\text { Purchase and sale of } \\
\text { durable goods }\end{array}$ & $\begin{array}{l}\text { Purchasing television } \\
\text { etc. }\end{array}$ & & & \\
\hline $\begin{array}{l}\text { Purchasing and sale of } \\
\text { land and houses }\end{array}$ & $\begin{array}{l}\text { Including involving in } \\
\text { sharecropping }\end{array}$ & & & \\
\hline $\begin{array}{l}\text { Representing the } \\
\text { household in the public }\end{array}$ & $\begin{array}{l}\text { Talking to govt. officials, } \\
\text { participating in the } \\
\text { discussions and group } \\
\text { meetings etc. }\end{array}$ & & & \\
\hline Male healthcare & $\begin{array}{l}\text { Go to the hospital, see } \\
\text { the doctor }\end{array}$ & & & \\
\hline Female healthcare & $\begin{array}{l}\text { Go to the hospital, } \\
\text { contraception, child } \\
\text { bearing }\end{array}$ & & & \\
\hline Children healthcare & $\begin{array}{l}\text { Go to the hospital, see } \\
\text { the doctor }\end{array}$ & & & \\
\hline $\begin{array}{l}\text { Male visiting } \\
\text { family/friends }\end{array}$ & $\begin{array}{l}\text { Visit his parents or } \\
\text { friends }\end{array}$ & & & \\
\hline $\begin{array}{l}\text { Female visiting } \\
\text { family/friends }\end{array}$ & $\begin{array}{l}\text { Visit his parents or } \\
\text { friends }\end{array}$ & & & \\
\hline
\end{tabular}

